RAFAELA FACIOLA COELHO DE SOUZA

\title{
Estudo da influência da sucção na pressão de expansão de materiais argilosos com a técnica da transferência de vapor
}

\begin{abstract}
Tese apresentada à Escola de Engenharia de São Carlos, da Universidade de São Paulo, como parte dos requisitos para obtenção do título de Doutor em Ciências, Programa de Pós Graduação em Geotecnia.
\end{abstract}

Orientador: Prof. Dr. Osni José Pejon

São Carlos

2014

Versão Corrigida - Versão Original se encontra disponível na Unidade que aloja o Programa 
AUTORIZO A REPRODUČ̃O TOTAL OU PARCIAL DESTE TRABALHO, POR QUALQUER MEIO COONVENCIONAL OU ELETRO̊NICO, PARA FINS DE ESTUDO E PESQUISA, DESDE QUE CITADA A FONTE.

Faciola Coelho de Souza, Rafaela

Estudo da influência da sucção na pressão de expansão de materiais argilosos com a técnica da transferência de vapor / Rafaela Faciola Coelho de Souza; orientador Osni José Pejon. São Carlos, 2014.

Tese (Doutorado) - Programa de Pós-Graduação e Área de Concentração em Geotecnia -- Escola de Engenharia de São Carlos da Universidade de São Paulo, 2014.

1. Pressão de expansão. 2. Sucção controlada. 3. Transferência de vapor. 4. Argilominerais. I. Título. 
Candidato: Bacharel RAFAELA FACIOLA COELHO DE SOUZA.

Título da Tese: "Estudo da influência da sucção na pressão de expansāo de materiais argilosos com a técnica da transferência de vapor".

Data da defesa: 12/03/2015

Comissâo Julgadora:

Prof. Titular Osni José Pejon (Orientador)

(Escola de Engenharia de São Carlos/EESC)

Prof. Titular Lázaro Valentin Zuquette

(Escola de Engenharia de Säo Carlos/EESC)
Resultado:
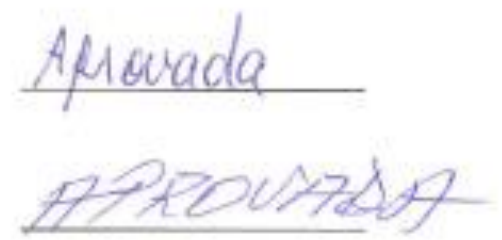

Dra. Elianc Martins Pereira

(Pesquisadora na Universidade Estadual Paulista "Júlio de Mesquita Filho"/UNESP - Rio Claro)

Prof. Dr, Roger Augusto Rodrigues

APDOVADA

(Universidade Estadual Paulista "Júlio de Mesquita Filho"/UNESP - Bauru)

Prof. Dr. Silvio Romero de Melo Ferreira

(Universidade Federal de Pernambuco/UFPE)

Coordenador do Programa de Pós-Graduaçāo em Geotecnia:

Prof. Dr. Edmundo Rogério Esquivel

Presidente da Comissão de Pós-Graduação:

Prof. Associado Paulo César Lima Segantine 



\section{AGRADECIMENTOS}

Ao Departamento de Geotecnia da Escola de Engenharia de São Carlos pela oportunidade, suporte técnico e conhecimento repassado pelo corpo docente.

Ao meu orientador, Dr. Osni José Pejon, pela orientação, atenção, dedicação, e conhecimento repassado para o desenvolvimento desse trabalho. Agradeço, também, pela confiança, paciência, e pelo apoio dado para que eu pudesse finalizar a tese. Muito obrigada!

Ao Conselho Nacional de Desenvolvimento Científico e Tecnológico - CNPq pela bolsa de estudos concedida.

Aos professores Dr. Lázaro Valentim Zuquette, Dr. Antenor Braga Paraguassú e Dr. Orêncio Monje Vilar pelas conversas e discussões técnicas.

Ao Técnico do Laboratório de Geossintéticos Clever Valentin pelas dicas, sugestões, conselhos, e por sempre estar disposto a ajudar.

Aos Técnicos de Laboratório de Solos, Sr. Antônio, José Luis, Dito e Décio, e em especial o meu "muito obrigada" ao Oscar, que me ajudou e acompanhou de perto o desenvolvimento dos ensaios.

Aos funcionários do Departamento de Geotecnia, Maristela, Neiva, e Álvaro, pela amizade e por todo o apoio dado durante os anos de convivência.

Ao Laboratório de Química Analítica, em nome da professora Maria Olímpia de Oliveira Rezende, pela disponibilização da realização das liofilizações. E em especial à Lívia Favoretto e Fernanda Benetti.

A todos os amigos do departamento e de São Carlos, em especial Wanessa, Luciene, Aline Zuquetinha, Simone Furegatti, Giovana, Jú Lukiantchuki, Thiago Santos, Paola, Claudinha, Felipe, Ana Elisa, Thaíse, João Sampaio, João Parizotto, Chris, Jussara, Primo, Bia, Marcilene Dantas, Liliana Xavier, Juliana Pereira, Filipe, Arthur, e ao meu grande amigo e parceiro Jefferson Lins. Obrigada Tatá (Thaíse Morais) pela formatação.

À minha coordenadora da Universidade Federal de Alagoas - UFAL, Campus do Sertão, Viviane Regina Costa, e aos amigos professores por me darem todo o suporte e apoio 
na finalização da tese. E a todos os meus alunos que puderam compreender a minha ausência em algumas aulas.

Ao Diego de Vasconcelos Gonçalves Ferreira, meu namorado, pelo incentivo, ajuda nas planilhas do excel e por estar sempre me apoiando.

Aos meus pais, Lina e Sérgio, e ao meu irmão Sergio Henrique, por serem minha grande fonte de inspiração. Por todas as orações, por todos os conselhos, e por todo o incentivo. Esse trabalho eu dedico com todo meu amor a vocês! 


\section{RESUMO}

SOUZA, R. F. C. Estudo da influência da sucção na pressão de expansão de materiais argilosos com a técnica da transferência de vapor. 2014. 244f. Tese (Doutorado) - Escola de Engenharia de São Carlos, Universidade de São Paulo, São Carlos, 2015.

Este trabalho apresenta a quantificação da expansão e suas características, principalmente a influência da sucção, em amostras de materiais sedimentares argilosos provenientes da Formação Corumbataí, aflorantes no interior do estado de São Paulo. Foram testadas amostras indeformadas, e amostras destorroadas e compactadas em diferentes umidades, em ensaios de pressão de expansão a volume constante por inundação, e também, com sucção controlada por meio da técnica da transferência de vapor. Foram ensaiadas, ainda, misturas compactadas desse material com bentonita em diferentes proporções, e misturas de bentonita com material não expansivo arenoso oriundo da Formação Botucatu. $\mathrm{O}$ controle de sucção foi realizado pelo uso de soluções salinas de $\mathrm{NaCl}$ em concentrações preparadas para impor sucções de $40.000,25.000,10.000$ e $5.000 \mathrm{kPa}$. Para a realização dos ensaios, construiu-se um sistema de aplicação de cargas e de aquisição automática dos dados de pressão. Para acelerar o processo de umedecimento por vapor, utilizou-se um reservatório externo ligado em uma bomba de ar adaptada para promover a circulação do vapor de ar para dentro da célula edométrica, especialmente construída para esta pesquisa. Os resultados de expansão nos ensaios com inundação mostraram pressões de expansão crescentes com a diminuição dos teores de umidade, e consequente aumento da sucção inicial das amostras ensaiadas, bem como crescentes com o aumento na proporção de bentonita nas misturas, com valores máximos em torno de $700 \mathrm{kPa}$ para o ensaio com a bentonita pura compactada seca. A análise da microestrutura das amostras por meio da porosimetria por intrusão de mercúrio permitiu constatar que as amostras indeformadas apresentaram variação, apenas, nos macroporos após a expansão; e as compactadas na umidade ótima e, posteriormente secas ao ar, não mostraram evolução significativa após a expansão. Na microscopia eletrônica de varredura (MEV) foi possível verificar a mudança nos vazios das amostras, bem como, visualizar a variação na estrutura e na textura. Além disso, no MEV foram confirmados, também, os argilominerais determinados na caracterização mineralógica. Os resultados dos ensaios de expansão com sucção controlada mostraram ausência de pressão de expansão para as amostras da Formação Corumbataí nas condições indeformada, e na condição compactada na umidade ótima e posteriormente seca ao ar. No entanto, esse material, quando compactado seco na forma de pó, e também, compactado seco misturado com bentonita em diferentes proporções, revelou pressões de expansão com a transferência de vapor, assim como, as misturas de bentonita com material não expansivo da Formação Botucatu. A ausência de expansão foi justificada pela forma lenta de umedecimento proporcionada pela transferência de vapor que, apesar de promover o aumento do teor de umidade das amostras, não mobilizou variação volumétrica suficientemente capaz de transmitir como pressão de expansão. Portanto, os ensaios de expansão, com a utilização da técnica de transferência de vapor, foram efetivos para avaliar a expansão somente nos casos em que argilominerais com potencial expansivo estavam presentes em proporções consideráveis.

Palavras-chave: Pressão de Expansão; Sucção Controlada; Transferência de Vapor; Argilominerais. 



\begin{abstract}
SOUZA, R. F. C. The influence of the suction in swelling pressure of clay materials with vapour transfer technique. 2014. 244f. Tese (Doutorado). Escola de Engenharia de São Carlos, Universidade de São Paulo, São Carlos.
\end{abstract}

This thesis presents the quantification and characterization of expansion, especially the influence of suction on samples of sedimentary materials from Corumbatai Formation that occurs in Sao Paulo. Undisturbed and compacted samples with different moisture contents were tested with swelling pressure tests at constant volume method by flooding, and also with suction control by vapour transfer technique. Compacted mixtures of this material with bentonite in differents proportions, and mixtures of bentonite with sandy non-expansive material from the Botucatu Formation were also tested. The suction control was performed by the use of $\mathrm{NaCl}$ salt solutions at concentrations prepared to perform 40,000, 25,000, 10,000 and $5,000 \mathrm{kPa}$ suctions. For the tests, it was developed a system for load application and automatic retrieval of pressure. To accelerate the wetting process by vapour, we used an external reservoir connected to an air pump adapted to promote air circulation inside the edometric cell, specially made for this study. The expansion results in flooding tests showed increasing swelling pressure with decreasing moisture content. Consequently there was an increase in the initial suction of the tested samples, which kept increasing as the rate of bentonite was raised in the mixtures, with a peak of ca. $700 \mathrm{kPa}$ for the test with dry pure bentonite compacted. In the microstructure analysis of the samples by mercury intrusion porosimetry, the samples showed variation only in macropores after swell; and the ones compacted at optimum moisture, and subsequently air dried, showed no significant change after the swell. In scanning electron microscopy (SEM) it was possible to verify the change in the voids of the samples, as well as to visualize the variation in the structure and texture. In addition, the SEM confirmed clay minerals deterninated in mineralogical characterization. The results of controlled suction with swell tests showed absence of swell pressure for Corumbatai samples tested in undisturbed conditions, and compacted condition at optimum moisture content, and then air dried. However, when compacted in the form of dry powder, as well as when compacted dry, mixed with different proportions of bentonite, this material showed swelling pressures with vapor transfer technique, as well as mixtures of bentonite with non-expansive material of Botucatu Formation. The absence of swell was explained by the slow damping provided by the vapor transfer that although promoting increasing dampen, did not sufficiently mobilized volume variation capable of transmitting blowing pressure. Therefore, the swell tests with the vapor transfer technique were effective to evaluate the swelling just in cases where clay minerals with swell potential were present in significant proportions.

Keywords: Swell Pressure; Control Suction; Vapour Transfer; Clay Mineralogy 



\section{LISTA DE FIGURAS}

Figura 2.1 - (a) Representação esquemática das folhas tetraédricas e octaédricas (adaptado de Grim, 1962)

Figura 2.2 - Distribuição de íons adjacentes na superfície da argila de acordo com o conceito da dupla camada difusa (Adaptado de Olphen, 1963).

Figura 2.3 - Teor de umidade moldado versus densidade seca e orientação das partículas: (a) Argila de Boston (Pacey, 1956); (b) Amostras de caulinita compactadas (Seed e Chan, 1959).

Figura 2.4 - Porosimetria por intrusão de mercúrio de amostras de solo argiloso compactado com o mesmo índice de vazios e diferentes teores de umidade (Adaptado de Cardoso et al., 2012)

Figura 2.5 - Representação da curva de retenção segundo Fredlund, Xing e Huang (1994), modificado de Pereira (2004).

Figura 2.6 - Representação das curvas de retenção para os tipos de solos (Vilar, 2000). .......53 Figura 2.7 - Tipos de curvas características de retenção de água do solo (Camapum de Carvalho e Leroueil, 2004).

Figura 2.8 - Modelo físico e o fenômeno relacionado à capilaridade (Fredlund e Rahardjo, 1993).

Figura 2.9 - Fenômenos de capilaridade e adsorção associados originando sucção matricial em solos não saturados (Hillel, 1971).

Figura 2.10 - Câmara de pressão de Richards (Libardi, 1995, modificado de Pereira, 2004). 64 Figura 2.11 - (a) Câmara de pressão de Richards (A - câmara de baixa pressão; B - painel para controle da pressão); (b) Amostras sobre a membrana conectada ao dreno da câmara de pressão (Fonte: EMBRAPA, 2007). .65

Figura 2.12 - Câmara de pressão alternativa (Georgetti et al., 2007).

Figura 2.13 - Técnica osmótica utilizada para determinação das propriedades de retenção de água (Cui e Delage, 1996). 68

Figura 2.14 - Desenho esquemático do tensiômetro (Fonte: INSA, 2013).....

Figura 2.15 - Umidade relativa versus sucção total (adaptado de Fredlund e Rahardjo, 1993).

Figura 2.16 - Sensibilidade de soluções salinas quanto à temperatura (Delage et al., 1998). .73 Figura 2.17 - Metodologias para determinação da pressão de expansão (Ferreira e Ferreira, 
Figura 2.18 - Equipamento para medida de expansão livre (adaptado de ISRM, 1989) 81

Figura 2.19 - Equipamento para medida de pressão de expansão axial (adaptado da ISRM, 1989). 82

Figura 2.20 - Edômetro com sucção controlada (Escario e Sáez, 1973)..... 84

Figura 2.21 - Equipamento para ensaio edométrico utilizando a técnica de controle de sucção por imposição de umidade relativa (Esteban e Sáez, 1988, modificado de Soto, 2004). 85 Figura 2.22 - Esquema do equipamento triaxial com controle de entrada e saída de água..... 87 Figura 2.23 - Equipamento de cisalhamento direto com sucção controlada (Adaptado de Fonseca, 1991). 88

Figura 2.24 - Classificação do potencial de expansão proposto por Seed et al. (1962b)........ 90 Figura 2.25 - Classificação da expansibilidade de materiais argilosos (Wiliams e Donaldson, 1980) 90

Figura 2.26 - Classificação mineralógica proposta por Pearing (1963) e Holt (1969). 91

Figura 2.27 - Representação dos valore de VB versus porcentagem de fração argilosa, com os respectivos valores de expansão livre (\%) (Pereira e Pejon, 1999, modificado de Pereira 2004).

Figura 2.28 - Resultados de IM versus Pressão de Expansão para diferentes sucções impostas (Pereira, 2004). 92

Figura 2.29 - Resultados de ICM e Pressões de Expansão para as diferentes sucções impostas (Pereira, 2004). 93

Figura 3.1 - Localização das cidades onde afloram os materiais da Formação Corumbataí e da Formação Botucatu no Estado de São Paulo (Perinotto et al., 2008). 96 Figura 3.2 - Coleta de amostras da Formação Corumbataí: (a) Talude às margens da rodovia, onde foram retiradas as amostras; (b) Detalhamento e aspecto geral da abertura feita no talude; (c) Moldagem do bloco indeformado; (d) Bloco moldado. 98 Figura 3.3 - Máquina de moagem e desfragmentação do material da Formação Corumbataí.99 Figura 3.4 - Equipamento para ensaio de Análise Térmica Diferencial. 100 Figura 3.5 - (a) Amostras coladas nos stubs antes de secar em estufa; (b) Amostras secas para ensaio.

Figura 3.6 - Corpos de prova de amostras indeformadas sobre pedra porosa para saturação. 106

Figura 3.7 - (a) Corpos de prova em processo de secagem; (b) Montagem do ensaio com papel filtro; (c) Corpos de prova moldados com papel filtro nas umidades calculadas; (d) Papel filtro seco após ensaio. 
Figura 3.8 - Processo de umedecimento: (a) Conjunto balança + proveta de umedecimento + amostra; (b) Detalhe de umedecimento e controle do peso da amostra.

Figura 3.9 - Anéis ensacados na caixa térmica para estabilização da umidade após umedecimento

Figura 3.10 - Funil de Placa Porosa (Adaptado de Georgetti, 2010). 110

Figura 3.11 - Detalhes das amostras dentro dos dessecadores de vidro. 111

Figura 3.12 - Corpos de prova nos dessecadores à vácuo.

Figura 3.13 - Dessecadores para calibração dos papéis de filtro.

Figura 3.14 - Detalhes da remoldagem dos corpos de prova indeformados: (a) amostra no torno mecânico; (b) Detalhe do corpo de prova após remoldagem.

Figura 3.15 - Prensa para compactação dos corpos de prova.

Figura 3.16 - Detalhes da preparação dos corpos de prova: (a) Montagem na prensa de compactação; (b) Corpo de prova compactado.

Figura 3.17 - Congelamento prévio com nitrogênio.

Figura 3.18 - Equipamento de liofilização de amostras.

Figura 3.19 - Peças para montagem da célula edométrica para ensaio com inundação.

Figura 3.20 - Esquema de montagem das peças da célula edométrica: (a) Corpo de prova na braçadeira; (b) Anel + abraçadeira; (c) Conjunto de anel + abraçadeira + corpo de prova + colar; (d) Base com reservatório; (e) Base + pedra porosa inferior; (f) Conjunto de anel + abraçadeira + corpo de prova + colar montados na base da célula edométrica.

Figura 3.21 - (a) Prensa com arranjo montado segundo ISRM (1989); (b) Prensa com arranjo modificado nesta pesquisa.

Figura 3.22 - Projeto modificado da prensa para ensaio de pressão de expansão (medidas em centímetro).

Figura 3.23 - Novo posicionamento dos deflectômetros na prensa. 122

Figura 3.24 - Célula de carga utilizada nos ensaios de pressão de expansão. 122 Figura 3.25 - Equipamento para medir pressão de expansão por transferência de vapor......125 Figura 3.26 - Peças de montagem da célula edométrica para ensaio com a técnica da transferência de vapor

Figura 3.27 - Montagem da célula edométrica: (a) Pedra porosa inferior; (b) Anel portaamostra acima da pedra porosa; (c) Colar de fixação do anel porta-amostra; (d) Pedra porosa superior + placa crivada; (e) Cilidro de acrílico; e (f) Tampa de célula edométrica. 127

Figura 3.28 - Reservatório de armazenamento para solução salina. 128

Figura 3.29 - Detalhes da preparação do reservatório de solução salina. 
Figura 3.30 - Bomba de ar para circulação do vapor.

Figura 3.31 - Detalhes da adaptação na bomba de circulação de ar.

Figura 3.32 - Sistema de aquisição de dados.

Figura 3.33 - Montagem do sistema de aquisição de dados.

Figura 3.34 - Disposição das prensas para medição da expansão com sistema de aquisição de dados.

Figura 4.1 - Curvas de distribuição granulométrica dos materiais analisados.

Figura 4.2 - Curvas de compactação do Material argiloso da Formação Corumbataí e do Material arenoso da Formação Botucatu (Loch, 2013).

Figura 4.3 - Termogramas obtidos nas análises térmicas diferencial (ATD): (a) Material da Formação Corumbataí; (b) Material da Formação Botucatu; (c) Bentonita. 135

Figura 4.4 - Difratogramas de Raios-X para lâminas tratadas nos procedimentos normal, aquecida à $550^{\circ} \mathrm{C}$ e banhadas na solução de etilenoglicol: (a) Amostra da Formação Corumbataí; (b) Amostra da Formação Botucatu; (c) Bentonita.

Figura 4.5 - Curva de retenção pelo método do papel filtro com trajetória de umedecimento para a amostra indeformada da Formação Corumbataí. 140

Figura 4.6 - Curva de retenção pelo método do papel filtro com trajetória de umedecimento para a amostra compactada da Formação Corumbataí. 141

Figura 4.7 - Curvas de retenção pelo método do papel filtro com trajetória de umedecimento e secagem para a amostra indeformada da Formação Corumbataí. 142

Figura 4.8 - Curvas de retenção pelo método do papel filtro com trajetória de umedecimento e secagem para a amostra compactada da Formação Corumbataí......

Figura 4.9 - Curva de retenção pelo método do dessecador a vácuo para amostra indeformada da Formação Corumbataí. 145

Figura 4.10 - Curva de retenção pelo método do dessecador a vácuo para amostra compactada da Formação Corumbataí. 146

Figura 4.11 - Pressões de expansão inundada em amostras indeformadas da Formação Corumbataí. 148

Figura 4.12 - Pressões de expansão em amostras compactadas da Formação Corumbataí. . 150 Figura 4.13 - Pressões de expansão inundada em amostras argilosas compactadas da Formação Corumbataí com bentonita. 151

Figura 4.14 - Pressões de expansão inundada em amostras arenosas compactadas da Formação Botucatu com bentonita. 
Figura 4.15 - Pressões de expansão com transferência de vapor em amostras argilosas compactadas da Formação Corumbataí misturadas com bentonita.

Figura 4.16 - Pressões de expansão com transferência de vapor em amostras arenosas compactadas da Formação Botucatu misturadas com bentonita.

Figura 5.1 - Pressão de expansão versus sucção das amostras indeformadas e compactadas da Formação Corumbataí.

Figura 5.2 - Porosimetria por intrusão de mercúrio para amostra indeformada na condição seca ao ar: (a) Porcentagem versus diâmetro dos poros; (b) Frequência dos intervalos de diâmetros

Figura 5.3 - Porosimetria por intrusão de mercúrio para amostra indeformada com umidade estabilizada na sucção de $40.000 \mathrm{kPa}$ : (a) Porcentagem versus diâmetro dos poros; (b) Frequência dos intervalos de diâmetros. 163

Figura 5.4 - Porosimetria por intrusão de mercúrio para a mostra indeformada com umidade estabilizada na sucção de $25.000 \mathrm{kPa}$ : (a) Porcentagem versus diâmetro dos poros; (b) Frequência dos intervalos de diâmetros.

Figura 5.5 - Porosimetria por intrusão de mercúrio para amostra indeformada com umidade estabilizada na sucção de $10.000 \mathrm{kPa}$ : (a) Porcentagem versus diâmetro dos poros; (b) Frequência dos intervalos de diâmetros. 164 Figura 5.6 - Porosimetria por intrusão de mercúrio para amostra indeformada com umidade estabilizada na sucção de $5.000 \mathrm{kPa}$ : (a) Porcentagem versus diâmetro dos poros; (b) Frequência dos intervalos de diâmetros.

Figura 5.7 - Microscopia eletrônica de varredura da amostra indeformada na condição seca ao ar antes do ensaio de expansão inundada. 168 Figura 5.8 - Substâncias químicas constituintes na amostra indeformada antes do ensaio de expansão inundada.

Figura 5.9 - Microscopia eletrônica de varredura da amostra indeformada na condição seca ao ar após do ensaio de expansão inundada.

Figura 5.10 - Porosimetria por intrusão de mercúrio para amostra compactada seca e umidade estabilizada seca ao ar: (a) Porcentagem versus diâmetro dos poros; (b) Frequência dos intervalos de diâmetros.

Figura 5.11 - Porosimetria por intrusão de mercúrio para amostra compactada na umidade ótima e estabilizada seca ao ar: (a) Porcentagem versus diâmetro dos poros; (b) Frequência dos intervalos de diâmetros. 
Figura 5.12 - Porosimetria por intrusão de mercúrio para amostra a amostra compactada na umidade ótima, e depois estabilizada na sucção de $40.000 \mathrm{kPa}$ : (a) Porcentagem versus diâmetro dos poros; (b) Frequência dos intervalos de diâmetros. 172 Figura 5.13 - Porosimetria por intrusão de mercúrio para amostra a amostra compactada na umidade ótima, e depois estabilizada na sucção de $25.000 \mathrm{kPa}$ : (a) Porcentagem versus diâmetro dos poros; (b) Frequência dos intervalos de diâmetros. 172 Figura 5.14 - Porosimetria por intrusão de mercúrio para amostra a amostra compactada na umidade ótima, e depois estabilizada na sucção de $10.000 \mathrm{kPa}$ : (a) Porcentagem versus diâmetro dos poros; (b) Frequência dos intervalos de diâmetros 172 Figura 5.15 - Porosimetria por intrusão de mercúrio para amostra a amostra compactada na umidade ótima, e depois estabilizada na sucção de $5.000 \mathrm{kPa}$ : (a) Porcentagem versus diâmetro dos poros; (b) Frequência dos intervalos de diâmetros. 173 Figura 5.16 - Microscopia eletrônica de varredura da amostra compactada seca, e seca ao ar após compactação antes do ensaio de expansão inundada 176 Figura 5.17 - Substâncias químicas constituintes na amostra compactada seca (pó), seca ao ar antes do ensaio de expansão inundada. 176 Figura 5.18 - Microscopia eletrônica de varredura da amostra compactada seca, e seca ao ar após o ensaio de expansão inundada. 177 Figura 5.19 - Microscopia eletrônica de varredura da amostra compactada na umidade ótima e seca ao ar antes do ensaio de expansão inundada. 178 Figura 5.20 - Microscopia eletrônica de varredura da amostra compactada na umidade ótima e seca ao ar após o ensaio de expansão inundada. 179 Figura 5.21 - Porosimetria por intrusão de mercúrio para amostra de bentonita compactada seca ao ar: (a) Porcentagem versus diâmetro dos poros; (b) Frequência dos intervalos de diâmetros. 181

Figura 5.22 - Porosimetria por intrusão de mercúrio para amostra argilosa com 70\% bentonita compactada seca ao ar: (a) Porcentagem versus diâmetro dos poros; (b) Frequência dos intervalos de diâmetros. Figura 5.23 - Porosimetria por intrusão de mercúrio para amostra argilosa com 50\% bentonita compactada seca ao ar: (a) Porcentagem versus diâmetro dos poros; (b) Frequência dos intervalos de diâmetros. 182 Figura 5.24 - Porosimetria por intrusão de mercúrio para amostra argilosa com 30\% bentonita compactada seca ao ar: (a) Porcentagem versus diâmetro dos poros; (b) Frequência dos intervalos de diâmetros. 
Figura 5.25 - Porosimetria por intrusão de mercúrio para amostra argilosa com $10 \%$ bentonita compactada seca ao ar: (a) Porcentagem versus diâmetro dos poros; (b) Frequência dos intervalos de diâmetros.

Figura 5.26 - Porosimetria por intrusão de mercúrio para amostra argilosa com 5\% bentonita compactada seca ao ar: (a) Porcentagem versus diâmetro dos poros; (b) Frequência dos intervalos de diâmetros.

Figura 5.27 - Microscopia eletrônica de varredura da amostra de bentonita compactada antes do ensaio de expansão inundada.

Figura 5.28 - Substâncias químicas constituintes na amostra de bentonita.

Figura 5.29 - Microscopia eletrônica de varredura da mistura de material argiloso com 70\% de bentonita.....

Figura 5.30 - Substâncias químicas constituintes na mistura de material argiloso com $70 \%$ de bentonita.

Figura 5.31 - Microscopia eletrônica de varredura da mistura de material argiloso com 50\% de bentonita.....

Figura 5.32 - Substâncias químicas constituintes na mistura de material argiloso com $50 \%$ de bentonita.

Figura 5.33 - Microscopia eletrônica de varredura da mistura de material argiloso com 30\% de bentonita. 190

Figura 5.34 - Substâncias químicas constituintes na mistura de solo argiloso com $30 \%$ de bentonita.

Figura 5.35 - Microscopia eletrônica de varredura da mistura de material argiloso com 10\% de bentonita.

Figura 5.36 - Microscopia eletrônica de varredura da mistura de material argiloso com 5\% de bentonita.

Figura 5.37 - Porosimetria por intrusão de mercúrio para amostra arenosa com $70 \%$ bentonita compactada seca ao ar: (a) Porcentagem versus diâmetro dos poros; (b) Frequência dos intervalos de diâmetros.

Figura 5.38 - Porosimetria por intrusão de mercúrio para amostra arenosa com 50\% bentonita compactada seca ao ar: (a) Porcentagem versus diâmetro dos poros; (b) Frequência dos intervalos de diâmetros.

Figura 5.39 - Porosimetria por intrusão de mercúrio para amostra arenosa com 30\% bentonita compactada seca ao ar: (a) Porcentagem versus diâmetro dos poros; (b) Frequência dos intervalos de diâmetros. 
Figura 5.40 - Microscopia eletrônica de varredura da mistura arenosa com 70\% de bentonita.

Figura 5.41 - Substâncias químicas constituintes na mistura arenosa com $70 \%$ de bentonita. 198

Figura 5.42 - Microscopia eletrônica de varredura da mistura arenosa com 50\% de bentonita. 199

Figura 5.43 - Substâncias químicas constituintes na mistura arenosa com 50\% de bentonita.

Figura 5.44 - Microscopia eletrônica de varredura da mistura arenosa com 30\% de bentonita. 200

Figura 5.45 - Substâncias químicas constituintes na mistura arenosa com 30\% de bentonita. 201

Figura 5.46 - Pressões máximas de expansão versus Porcentagem de Bentonita para ensaios inundados e ensaios por transferência de vapor nas misturas argilosas. 208 Figura 5.47 - Pressões máximas de expansão versus Porcentagem de Bentonita para ensaios inundados e ensaios por transferência de vapor nas misturas arenosas. 209 Figura 5.48 - Curva de pressão de expansão versus porcentagem de bentonita para misturas argilosas e arenosas nos ensaios com a transferência de vapor. 210 Figura 5.49 - Pressão máxima de expansão e densidade seca inicial entre as misturas argilosas com bentonita.

Figura 5.50 - Pressão máxima de expansão e densidade seca inicial entre as misturas arenosas com bentonita.

Figura 5.51 - Pressão máxima de expansão e umidade inicial entre as misturas argilosas com bentonita.

Figura 5.52 - Pressão máxima de expansão e umidade inicial entre as misturas arenosas com bentonita.

Figura 5.53 - Expansão inundada após transferência de vapor para as misturas de solo argiloso com bentonita.

Figura 5.54 - Expansão inundada após transferência de vapor para as misturas de material arenoso com bentonita. 


\section{LISTA DE TABELAS}

Tabela 2.1 - Argilominerais filossilicáticos e suas características principais.........................31

Tabela 2.2 - Capacidade de troca de cátions de minerais de argila (Grim, 1953)..................35

Tabela 2.3 - Valores típicos de expansão livre para argilominerais comuns (Grim, 1962).....37

Tabela 2.4 - Relações empíricas para estimativa da curva de retenção de água no solo. ........57

Tabela 2.5 - Equações propostas para tensões efetivas em solos não saturados (Adaptado de

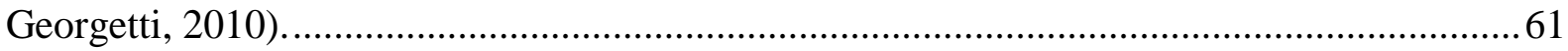

Tabela 2.6 - Métodos para medida de sucção (Vilar, 2002).................................................62

Tabela 2.7 - Tempo de equilíbrio sugerido para medida de sucção total, em função do nível

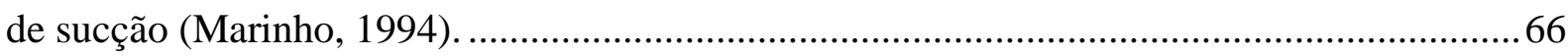

Tabela 2.8 - Valores de Sfdo, A, B, C e D apresentados por Lang (1967)............................72

Tabela 2.9 - Métodos indiretos e diretos de identificação de solos expansivos (Ferreira, 1995

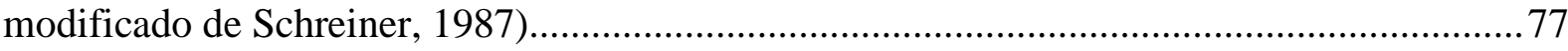

Tabela 2.10 - Classificação dos solos baseado no índice de expansão livre (Prakash e

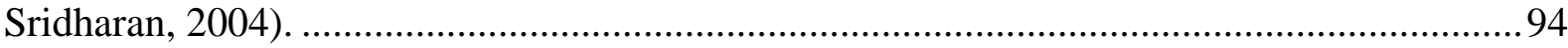

Tabela 2.11- Correlações para características de expansão (Rao et al., 2004).......................94

Tabela 3.1 - Amostras ensaiadas com a técnica da transferência de vapor. .......................... 124

Tabela 4.1 - Características geotécnicas dos materiais.................................................... 133

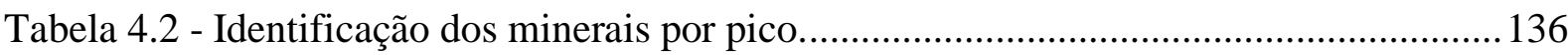

Tabela 4.3 - Identificação dos minerais a partir dos difratogramas de raios-X.................... 138

Tabela 4.4 - Parâmetros calculados no ensaio de azul de metileno........................................139

Tabela 4.5 - Atividade dos argilominerais presente nas amostras (Lautrin, 1989)............... 139

Tabela 4.6 - Parâmetros de ajuste dos modelos matemáticos aos dados experimentais da curva de retenção com sucção total das amostras indeformada e compactada.

Tabela 4.7 - Parâmetros de ajuste dos modelos matemáticos aos dados experimentais da curva de retenção com sucção matricial da amostra indeformada para a trajetória de secagem......142 Tabela 4.8 - Parâmetros de ajuste dos modelos matemáticos aos dados experimentais da curva de retenção com sucção matricial da amostra indeformada para a trajetória de umedecimento.

Tabela 4.9 - Parâmetros de ajuste dos modelos matemáticos aos dados experimentais da curva de retenção com sucção matricial da amostra compactada para a trajetória de secagem. 
Tabela 4.10 - Parâmetros de ajuste dos modelos matemáticos aos dados experimentais da curva de retenção com sucção matricial da amostra compactada para a trajetória de umedecimento.

Tabela 4.11 - Parâmetros de ajuste dos modelos matemáticos aos dados experimentais da curva de retenção com sucção total da amostra indeformada pelo método do dessecador a vácuo. 145

Tabela 4.12 - Parâmetros de ajuste dos modelos matemáticos aos dados experimentais da curva de retenção com sucção total da amostra compactada pelo método do dessecador a vácuo.

Tabela 4.13 - Nomenclatura das amostras indeformadas da Formação Corumbataí. 147

Tabela 4.14 - Índices físicos de moldagem das amostras indeformadas da Formação Corumbataí.

Tabela 4.15 - Índices físicos das amostras indeformadas da Formação Corumbataí antes do ensaio de expansão inundada. 148

Tabela 4.16 - Pressões máximas de expansão inundada em amostras indeformadas da Formação Corumbataí. 148

Tabela 4.17 - Nomenclatura das amostras indeformadas da Formação Corumbataí. 149

Tabela 4.18 - Índices físicos de moldagem das amostras compactadas da Formação Corumbataí. 149

Tabela 4.19 - Índices físicos das amostras compactadas da Formação Corumbataí. 149

Tabela 4.20 - Pressões máximas de expansão inundada em amostras compactadas da Formação Corumbataí. 150

Tabela 4.21 - Nomenclatura das misturas argilosas da Formação Corumbataí com bentonita. 151

Tabela 4.22 - Índices físicos das amostras argilosas compactadas da Formação Corumbataí com bentonita. 151

Tabela 4.23 - Pressões máximas de expansão inundada nas misturas de material argiloso compactado da Formação Corumbataí com bentonita.

Tabela 4.24 - Sucções iniciais das misturas de material da Formação Corumbataí com bentonita antes dos ensaios.

Tabela 4.25 - Nomenclatura das misturas arenosas da Formação Botucatu com bentonita.. 153 Tabela 4.26 - Índices físicos das amostra arenosas compactadas da Formação Botucatu com bentonita antes do ensaio de expansão inundada. 
Tabela 4.27 - Pressões máximas de expansão inundada em amostras arenosas compactadas da Formação Botucatu com bentonita.

Tabela 4.28 - Sucções iniciais das amostras arenosas compactadas da Formação Botucatu com bentonita antes dos ensaios

Tabela 4.29 - Índices físicos das amostras argilosas compactadas da Formação Corumbataí misturadas com bentonita, antes do ensaio de expansão por transferência de vapor.

Tabela 4.30 - Pressões máximas de expansão por transferência de vapor em amostras argilosas compactadas da Formação Corumbataí misturadas com bentonita. 155

Tabela 4.31 - Sucções iniciais antes dos ensaios das amostras argilosas compactadas da Formação Corumbataí misturadas com bentonita.

Tabela 4.32 - Índices físicos das amostras arenosas compactadas da Formação Botucatu misturadas com bentonita antes do ensaio de expansão por transferência de vapor. 156

Tabela 4.33 - Pressões máximas de expansão por transferência de vapor em amostras arenosas compactadas da Formação Botucatu misturadas com bentonita.

Tabela 4.34 - Sucções iniciais antes dos ensaios das amostras compactadas arenosas da Formação Botucatu misturadas com bentonita. 158

Tabela 5.1 - Características dos ensaios de máxima pressão de expansão. 160

Tabela 5.2 - Índices físicos das amostras de máxima expansão. 160

Tabela 5.3 - Porcentagem de distribuição dos poros nas amostras indeformadas da Formação Corumbataí. 166

Tabela 5.4 - Comparação entre porosidade calculada e a porosidade determinada pela PIM para as amostras indeformadas da Formação Corumbataí.

Tabela 5.5 - Porcentagem de distribuição dos poros das amostras compactadas. 174

Tabela 5.6 - Comparação entre porosidade calculada e a porosidade determinada pela PIM para as amostras compactadas da Formação Corumbataí. 175

Tabela 5.7 - Porcentagem de distribuição dos poros das amostras argilosas compactadas da Formação Corumbataí misturadas com bentonita.

Tabela 5.8 - Comparação entre porosidade calculada e a porosidade determinada pela PIM para as amostras argilosas compactadas da Formação Corumbataí misturadas com bentonita.

Tabela 5.9 - Porcentagem de distribuição de poros das amostras arenosas compactadas da Formação Botucatu misturadas com bentonita. 196

Tabela 5.10 - Comparação entre porosidade calculada e a porosidade determinada pela PIM para as amostras arenosas compactadas da Formação Botucatu misturadas com bentonita. . 196 
Tabela 5.11 - Tipos de amostras e condições de ensaios que não houve expansão. 202

Tabela 5.12 - Índices físicos das amostras antes dos ensaios............................................. 202

Tabela 5.13 - Índices físicos das amostras após o ensaio.................................................... 203

Tabela 5.14 - Sucção inicial das amostras sem expansão. ................................................ 203

Tabela 5.15 - Valores de índices físicos e pressões máximas de expansão para as amostras de

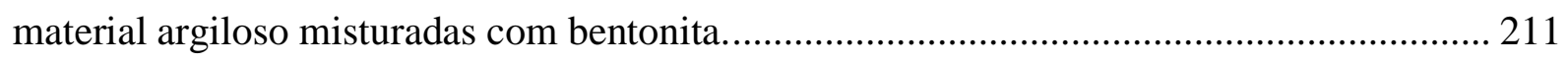
Tabela 5.16 - Valores de índices físicos e pressões máximas de expansão para as amostras de

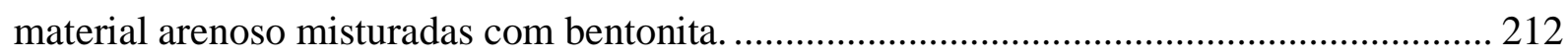
Tabela 5.17 - Sucção final dos ensaios de transferência de vapor medidos com o papel filtro.

Tabela 5.18 - Pressões de expansão final após transferência de vapor, e pressões finais do ensaio inundado direto para as misturas de material argiloso com bentonita.

Tabela 5.19 - Pressões de expansão final após transferência de vapor, e pressões finais do ensaio inundado direto para as misturas de material arenoso com bentonita. 218 


\section{SUMÁRIO}

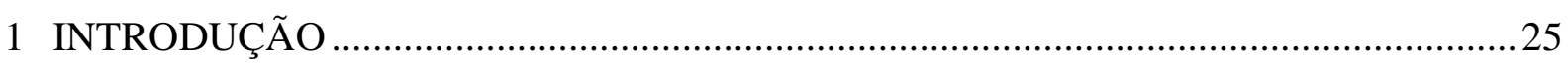

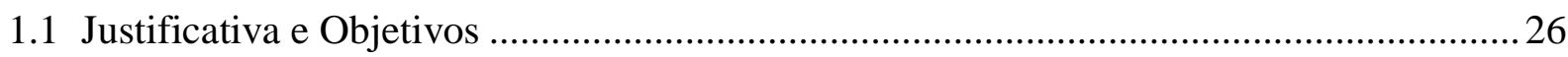

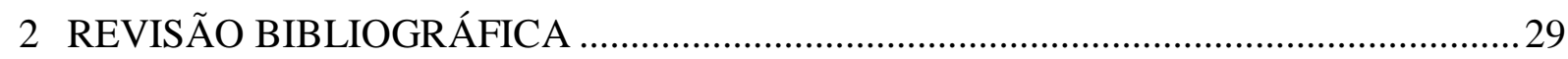

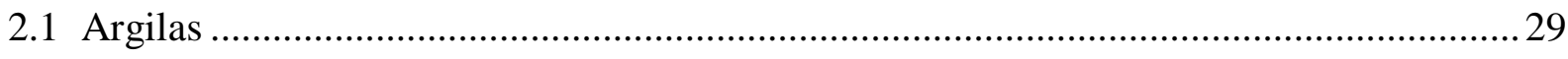

2.1.1 Principais Tipos de Argilominerais ........................................................................... 30

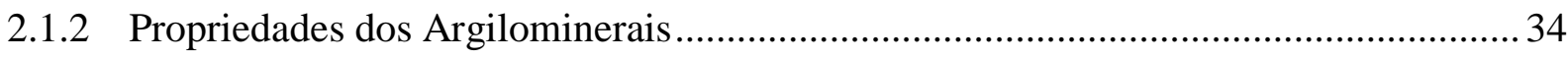

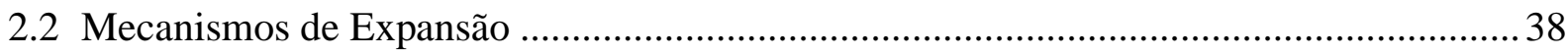

2.2.1 Fatores que Afetam a Expansão............................................................................... 40

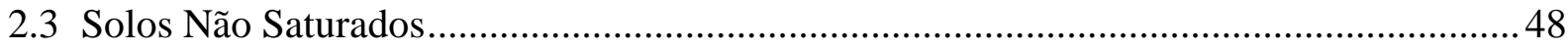

2.3.1 Fases Constituintes do Solo Não Saturado …………………………………............ 48

2.3.2 Potencial de Água no Solo .............................................................................. 48

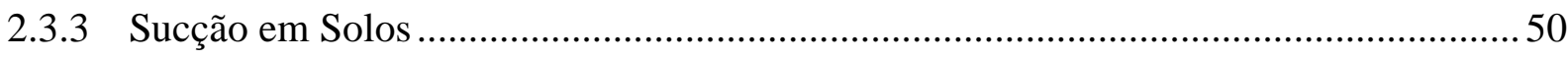

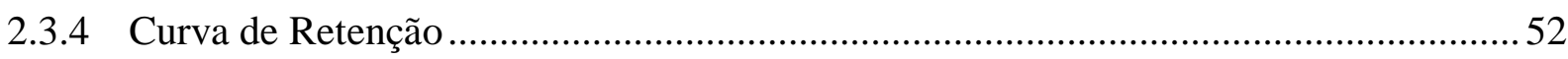

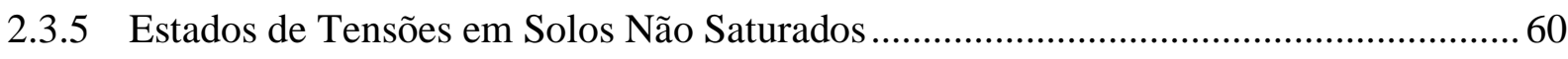

2.4 Métodos de Determinação da Sucção ......................................................................... 61

2.4.1 Técnica da Translação de Eixos.............................................................................. 63

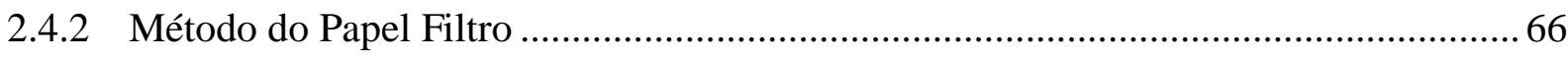

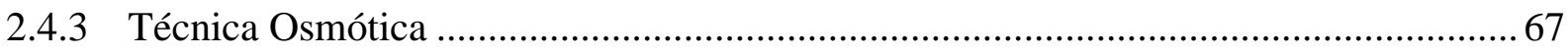

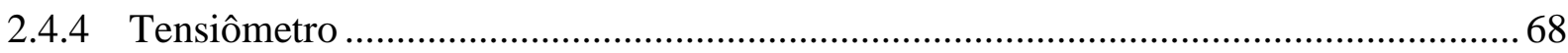

2.4.5 Técnica de Controle da Sucção por Imposição de Umidade Relativa .............................69

2.5 Identificação de Solos Expansivos …………………………………………………....76

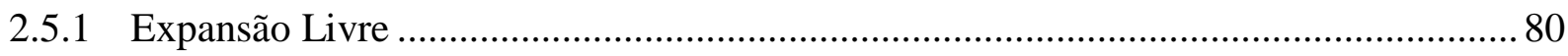

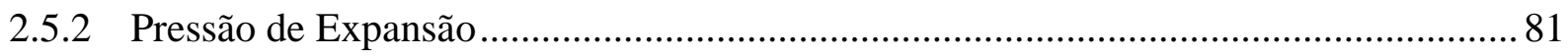

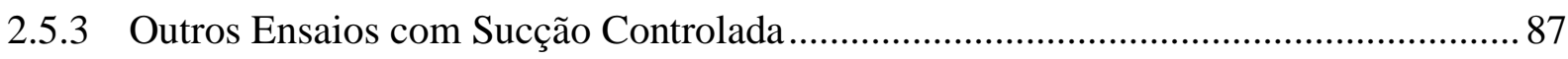

2.6 Correlações para Classificação de Solos Expansivos ........................................................... 89 


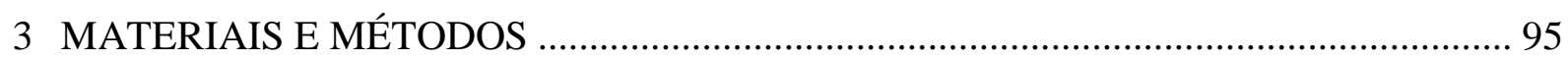

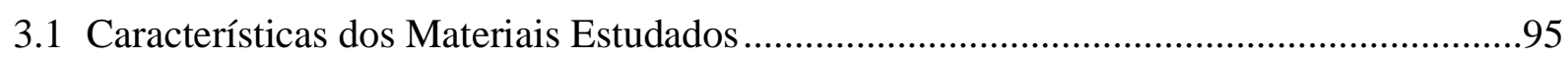

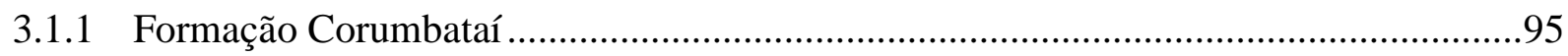

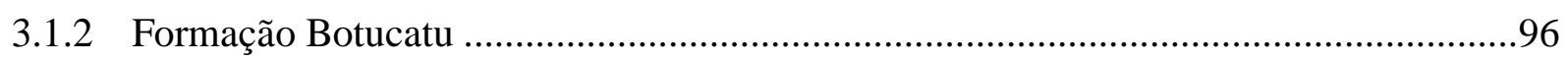

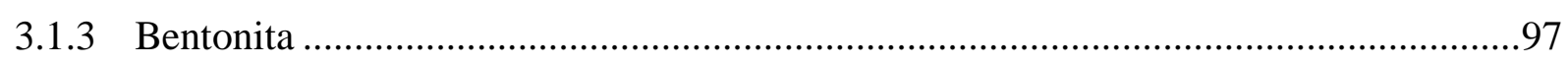

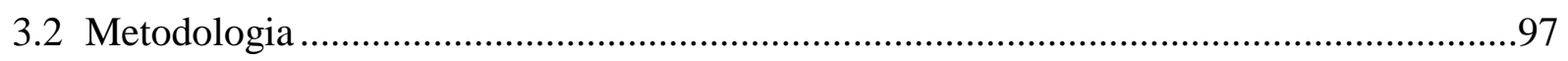

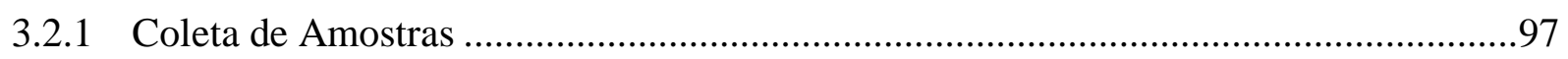

3.2.2 Ensaios de Caracterização Geotécnica ..................................................................99

3.2.3 Ensaios de Caracterização Mineralógica.................................................................99

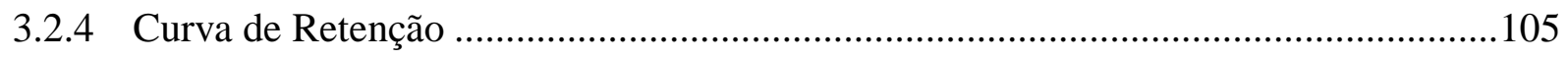

3.2.5 Preparação dos Corpos de Prova para Ensaios de Expansão ......................................112

3.2.6 Pressão de Expansão por Inundação …...............................................................116

3.2.7 Pressão de Expansão por Transferência de Vapor ....................................................124

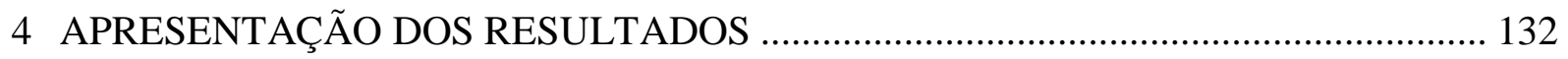

4.1 Ensaios de Caracterização Geotécnica.....................................................................132

4.2 Ensaios de Caracterização Mineralógica .......................................................................135

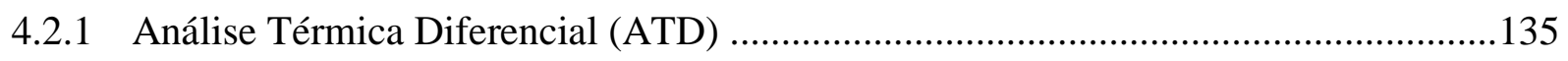

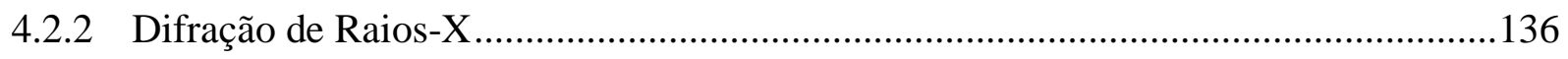

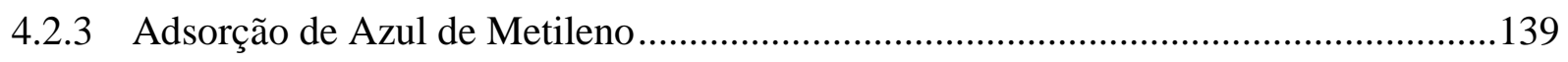

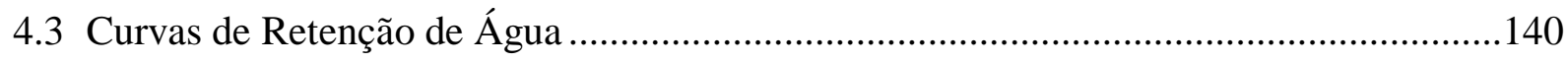

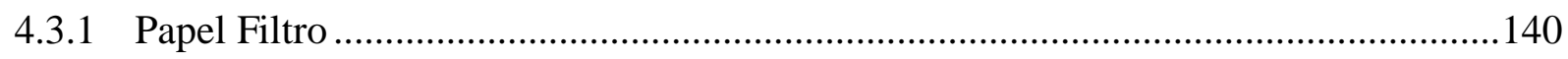

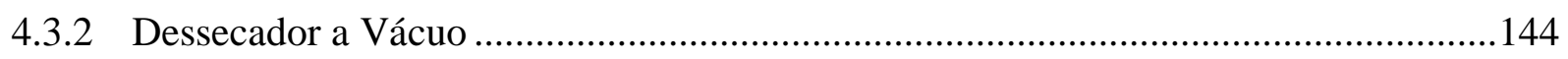

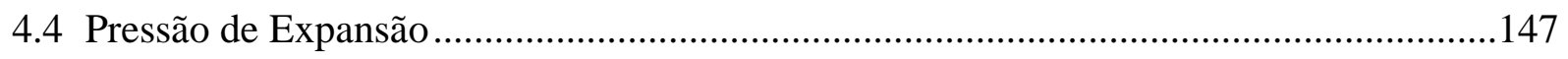

4.4.1 Ensaios de Expansão por Inundação ......................................................................147

4.4.2 Ensaios de Expansão com Transferência de Vapor ...................................................154

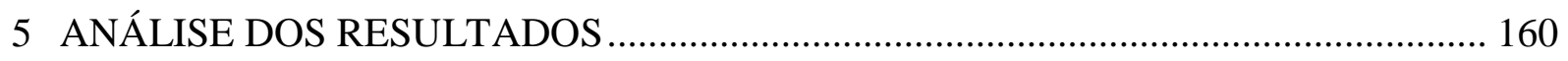

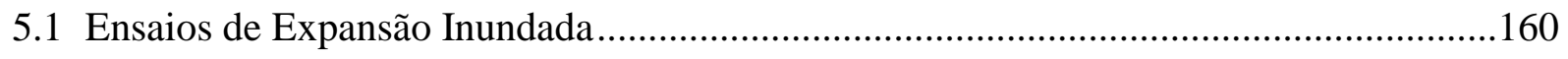


5.1.1 Comportamento das Amostras Indeformadas e Compactadas da Formação Corumbataí

5.1.2 Comportamento das Misturas de Material Argiloso da Formação Corumbataí com bentonita

5.1.3 Comportamento das Misturas de Material Arenoso da Formação Botucatu com Bentonita

5.1.4 Comparação entre as Misturas de Material Argiloso e Material Arenoso com Bentonita

5.2 Ensaios de Expansão com a Técnica da Transferência de Vapor 202

5.2.1 Resultados das Amostras que não Apresentaram Expansão 202

5.2.2 Resultados das Amostras que Apresentaram Expansão 205

5.2.3 Comparação entre Pressões Máximas de Expansão nas Misturas 209

5.2.4 Comparação entre Pressão Máxima de Expansão e Densidade Seca Inicial 210

5.2.5 Comparação entre Pressão Máxima de Expansão e Umidade Inicial 213

5.2.6 Sucção Final dos Ensaios com a Transferência de Vapor 215

5.3 Expansão Inundada após Transferência de Vapor 216

6 CONCLUSÕES 219

6.1 Características dos Materiais Analisados

6.2 Comportamento Expansivo

6.2.1 Expansão Inundada

6.2.2 Expansão por Transferência de Vapor

6.2.3 Expansão Inundada versus Transferência de Vapor

6.3 Metodologias de Ensaio - Equipamento Desenvolvido na Pesquisa 223

6.4 Sugestões para Trabalhos Futuros 223

7 REFERÊNCIAS BIBLIOGRÁFICAS 225 



\section{INTRODUÇÃO}

A ocorrência de solos com potencial expansivo acarreta inúmeros problemas em obras de engenharia. Esse tipo de material apresenta um comportamento peculiar que se manifesta durante o umedecimento e secagem, resultando em uma variação de volume, o que provoca levantamentos ou deslocamentos das estruturas. Essa variação de volume origina uma pressão de expansão causada pela presença de argilominerais com características intrínsecas que afetam as propriedades mecânicas das rochas.

Estruturas apoiadas sobre solos expansivos podem estar sujeitas a danos estruturais nas edificações, rodovias, aeroportos, dentre todos os tipos de obra sobre eles apoiadas. Esses efeitos indesejados despertam a necessidade de um constante aprimoramento de conhecimentos e inovações direcionados ao campo de estabilidade na fundação das estruturas sobre materiais expansivos, no que diz respeito à previsão e prevenção desses efeitos.

Autores como Vilar (1992), Pejon (2000) e Pereira (2004), mostraram que o fenômeno de expansão depende de inúmeros fatores internos e externos, evidenciados por meio de correlações entre diversos ensaios. $\mathrm{O}$ esclarecimento dos problemas relativos à expansibilidade relaciona-se com a composição mineralógica, textura, micro e macro porosidade, variação volumétrica e com a sucção, que está consequentemente relacionada a problemas de solos não saturados.

De acordo com Murthy (2003) é possível detectar, em vários países, problemas envolvendo solos expansivos, com maiores ocorrências na Austrália, Estados Unidos, Canadá, China, Israel, Índia e Egito. Há indícios, também, de solos expansivos na Espanha. Nos Estados Unidos, o custo anual associado a danos provocados pela presença desses materiais atingiram 9 bilhões de dólares em 1987 (Jones e Jones, 1987). No Brasil, os solos expansivos são encontrados no Rio Grande do Norte, Sergipe, Pernambuco, Bahia, Alagoas, Distrito Federal, São Paulo, Paraná e Rio Grande do Sul. Contudo, não se tem dados específicos com relação aos danos causados por esse problema (Ferreira, 2007).

No estado de São Paulo, os materiais sedimentares da Formação Corumbataí apresentaram indícios de expansibilidade de acordo com os estudos realizados por Vilar (1992) e Pejon (2000). Portanto, a carência de materiais com melhor qualidade geotécnica para utilização como material de construção requer estudos especiais para identificação e determinação da 
pressão de expansão. Neste sentido, este trabalho busca aprofundar os estudos realizados com os materiais potencialmente expansivos provenientes desta formação frente a diferentes formas de umedecimento na tentativa de explicar a diferença de comportamento.

Esta pesquisa estudou o comportamento de materiais potencialmente expansivos a partir de ensaios de expansão por inundação e ensaios de expansão com e sem o controle da sucção por transferência de vapor, a fim de determinar a pressão de expansão. O trabalho apresentou, também, a caracterização geotécnica e mineralógica, bem como a caracterização físicoquímica dos materiais para verificar e quantificar a influência dessas propriedades na expansão.

Com base nestes resultados, foi possível inferir quais as propriedades relacionadas ao comportamento expansivo. Além disso, foi realizada uma análise do comportamento da porosidade dos materiais antes e após a expansão por inundação. As pressões de expansão foram analisadas e interpretadas para cada tipo de material e para cada técnica aplicada, obtendo informações de expansão, visando justificar alguns questionamentos a respeito desse comportamento.

\subsection{Justificativa e Objetivos}

O objetivo geral da pesquisa foi estudar o comportamento expansivo de materiais da Formação Corumbataí, no que diz respeito à mudança de umidade, sucção e variação de volume. A análise da expansibilidade desses materiais levou em consideração a realização de ensaios de expansão a volume constante, com e sem sucção controlada. Realizaram-se, também, ensaios de expansão desse material misturado com bentonita, a fim de avaliar a expansão do material argiloso com um material puramente expansivo, e ainda, tentar justificar a não expansão que ocorre desses materiais quando ensaiados em certas condições de umedecimento.

Para tanto, foi necessário compreender a influência do processo de umedecimento na expansão dos solos e materiais sedimentares. Estudos de Pereira (2004), em solos da Formação Guabirotuba, demonstraram que quando o umedecimento se processa lentamente por transferência de vapor o solo não expande, no entanto, quando se faz o umedecimento por inundação a expansão é rápida e muito intensa. Portanto, este trabalho se justifica por verificar se este comportamento também ocorre com os materiais da Formação Corumbataí, e 
explicar as razões que levam a não expansão de materiais argilosos em certas condições testadas com umedecimento em forma de vapor.

Partindo destas premissas, a pressão de expansão dos materiais da Formação Corumbataí foi determinada por meio de ensaios de expansão com e sem controle de sucção em amostras indeformadas, amostras compactadas e em amostras desse material misturadas com diferentes proporções de bentonita. Visto que, até o momento, as pesquisas realizadas com esse material contemplaram a determinação da expansão livre e pressão de expansão sem levar em consideração a sucção. De forma complementar, foram analisadas expansões de misturas de material arenoso da Formação Botucatu com bentonita em diferentes proporções, para verificar o comportamento expansivo da bentonita com um material não expansivo.

Vincula-se nesse objetivo uma caracterização mais detalhada que auxilia no esclarecimento e avaliação do comportamento expansivo, os quais contemplam os objetivos específicos e são descritos a seguir:

- Determinar da sucção das amostras pelo método do papel filtro e pelo dessecador a vácuo. Construção das curvas de retenção e análises do comportamento do solo sob a condição natural e compactada;

- Verificar a validade dos métodos de ajuste das curvas de retenção existentes na literatura para os pontos obtidos com as amostras;

- Comparar do comportamento à expansão de amostras indeformadas e de amostras compactadas secas da Formação Corumbataí em ensaios de expansão inundada;

- Comparar do comportamento à expansão de amostras compactadas secas da Formação Corumbataí misturadas com bentonita em diferentes proporções em ensaios de expansão inundada;

- Análisar o comportamento à expansão de amostras arenosas compactadas secas da Formação Botucatu misturadas com bentonita em diferentes proporções em ensaios de expansão inundada. Comparar esse comportamento com os das misturas de material da Formação Corumbataí com bentonita;

- Análisar do comportamento à expansão de amostras argilosas e amostras arenosas compactadas secas misturadas com bentonita em diferentes proporções em ensaios de expansão com a transferência de vapor. Comparar esse comportamento com os das misturas de material da Formação Corumbataí com bentonita; 
- Avaliar o controle de sucção pela técnica da transferência de vapor por meio de imposição de umidade relativa utilizada para determinar a pressão de expansão. Dessa forma, analisar o controle da velocidade de entrada de água nas amostras e modos de umedecimento no processo expansivo;

- Verificar o desempenho e funcionalidade do equipamento desenvolvido nesta pesquisa para medir a expansão com e sem o controle de sucção. 


\section{REVISÃO BIBLIOGRÁFICA}

A variação volumétrica de solos devido à expansibilidade ocorre geralmente com aqueles de natureza argilosa ou argilosiltosa. Os argilominerais predominantes em solos expansivos pertencem ao grupo das esmectitas, representado principalmente pela montmorilonita e pelo grupo das vermiculitas (Chen, 1988).

O comportamento expansivo de um solo é governado pelo tipo de argilomineral presente, e também, pela microestrutura. Os argilominerais apresentam características intrínsecas que afetam a expansibilidade variando de grupo para grupo, podendo ser elevada para minerais do grupo das esmectitas e praticamente nula para minerais do grupo das caulinitas (Frazão e Goulart, 1976). Os autores afirmam que a gênese dos solos expansivos está intimamente relacionada com a ocorrência de argilominerais.

O tamanho diminuto da fração argila dos solos conduz a um comportamento coloidal das partículas, no qual pequenas quantidades deste tipo de material causa mudanças drásticas na maioria de suas propriedades, sejam físicas ou físico-químicas (Leite, 2000).

\subsection{Argilas}

De acordo com Santos (1989), a fração argila de uma rocha sedimentar de granulação fina é formada em sua maioria por uma porção de minerais constituídos de silicatos hidratados de alumínio, com quantidades variáveis de ferro, magnésio, potássio, sódio, etc. Apresentam estrutura, geralmente, lamelar com grau de cristalinidade bastante variável. Esses silicatos hidratados são denominados de minerais de argila na fração menor que $2 \mu \mathrm{m}$. Na petrografia, as argilas são indicadas como material fino e de aparência terrosa, que se torna plástico após a mistura de uma certa quantidade de água (Frazão e Goulart, 1976).

São colóides eletronegativos que apresentam alta capacidade de troca de cátions e ânions, assim como, capacidade de absorção de água. Além disso, são susceptíveis à dispersão e floculação, e possuem alta plasticidade. A facilidade de trocar cátions varia em função da concentração de íons trocáveis e adsorvidos, da dimensão, natureza e do seu potencial de hidratação (Guerra et al., 2009). 
A elevada superfície específica facilita os fenômenos de troca entre os íons dos argilominerais e aqueles em solução aquosa. Os argilominerais, quando entram em contato com a água, aumentam o volume interplanar basal, o que facilita as reações físico-químicas de troca iônica (exceto as camadas de 1:1, que não são expansivas), e relaciona-se ao potencial de expansão dos argilominerais (Guerra et al.., 2009; Santos, 1992).

Os argilominerais são formados pela combinação de duas unidades básicas, uma camada tetraédrica silicática e uma camada octaédrica aluminosa. As folhas são organizadas em camadas alternadas, onde a camada tetraédrica de oxigênio e silício ou alumínio e a camada octaédrica de oxigênio ou $\mathrm{OH}^{-}$são ocupadas na parte central por cátions de $\mathrm{Al}^{3+}, \mathrm{Fe}^{3+}, \mathrm{Mg}^{2+} \mathrm{e}$ $\mathrm{Fe}^{2+}(\mathrm{Grim}, 1953)$.

Frazão e Goulart (1976) afirmam que estas duas camadas têm existência apenas na teoria, não ocorrendo de forma isolada na natureza. A combinação dessas camadas em diversas proporções originam os argilominerais. Essa combinação ocorre pela substituição do oxigênio no vértice livre dos tetraedros de $\left(\mathrm{SiO}_{4}\right)^{4-}$ pelo $\mathrm{OH}$ da camada octaédrica. Portanto, um mineral de argila pode crescer lateralmente pela união de novas camadas tetraédricas e octaédricas, mas a sua espessura só pode aumentar pela superposição de novas camadas básicas, semelhante a uma pilha de papel (Frazão e Goulart, 1976).

O processo de formação se dá quando os minerais de quartzo, feldspato, mica, anfibólio e piroxênio que constituem as rochas silicatadas da crosta terrestre expõem-se à atmosfera tornando-se instáveis. A água, ao penetrar nos poros e micro fraturas desses minerais dissolve os seus constituintes, que por sua vez, tentam se reorganizar em solução com participação de água, oxigênio, dióxido de carbono e íons dissolvidos. Dessa forma, permitem a formação de minerais argilosos, e consequentemente, de argilominerais que ficarão em equilíbrio nas condições atmosféricas. Os materiais que servem como base à formação dos argilominerais podem ser minerais não argilosos, minerais pré-existentes, suspensões coloidais e íons em soluções aquosas. Estes materiais constituem a origem dos processos formadores das argilas, os quais são classificados em neoformados, herdados ou transformados (Meira, 2011).

\subsubsection{Principais Tipos de Argilominerais}

A principal classificação dos argilominerais é dada em função da razão entre as folhas tetraédricas e octaédricas nas camadas, onde são divididas por grupos (Moore e Reynolds, 
1997). Os grupos dos argilominerais são definidos em vários tipos como listados na Tabela 2.1 .

Tabela 2.1 - Argilominerais filossilicáticos e suas características principais.

\begin{tabular}{cccccc}
\hline Grupo & Tipo de Camada & $\begin{array}{c}\mathbf{C T C} \\
\left(\mathbf{c m o l}_{\mathbf{c}} / \mathbf{k g}\right)\end{array}$ & $\mathbf{S E}\left(\mathbf{m}^{2} / \mathbf{g}\right)$ & $\begin{array}{c}\text { Espaçamento } \\
(\mathbf{n m})\end{array}$ & $\begin{array}{c}\text { Atividade } \\
\text { Coloidal }\end{array}$ \\
\hline Mica & $2: 1$ & $20-40$ & $70-120$ & 1,0 & Alta \\
Vermiculita & $2: 1$ & $120-100$ & $600-800$ & $1,0-1,5$ & Alta \\
Montmorilonita & $2: 1$ & $80-120$ & $600-800$ & Variável & Muito Alta \\
Clorita & $2: 1: 1$ & $20-40$ & $70-150$ & 1,4 & Média \\
Caulinita & $1: 1$ & $1-10$ & $10-20$ & 0,72 & Baixa \\
\hline
\end{tabular}

Os argilominerais que pertencem a classe dos filossilicatos são estruturados em folhas e camadas de tetraedros e octaedros, sendo constituídos respectivamente de unidades compostas alternadas por cátions de silício ou alumínio coordenado por oxigênio, e coordenado por alumínio.

De acordo com Grim (1953), as folhas tetraédricas são formadas por um arranjo hexagonal que se repete indefinidamente, de composição $\mathrm{Si}_{4} \mathrm{O}_{6}(\mathrm{OH})_{4}$, constituídas por um átomo de silício com quatro átomos de oxigênio ou dois planos de hidroxila para equilibrar a estrutura. As folhas octaédricas são formadas por um plano de cátions entre dois planos de hidroxilas ou oxigênio. Os cátions são coordenados por seis hidroxilas, que se dispõem nos vértices de um octaedro. O compartilhamento das hidroxilas ou oxigênio pelos octaedros nas proximidades geram um arranjo hexagonal de unidades que se repetem formando uma camada (Figura 2.1). 


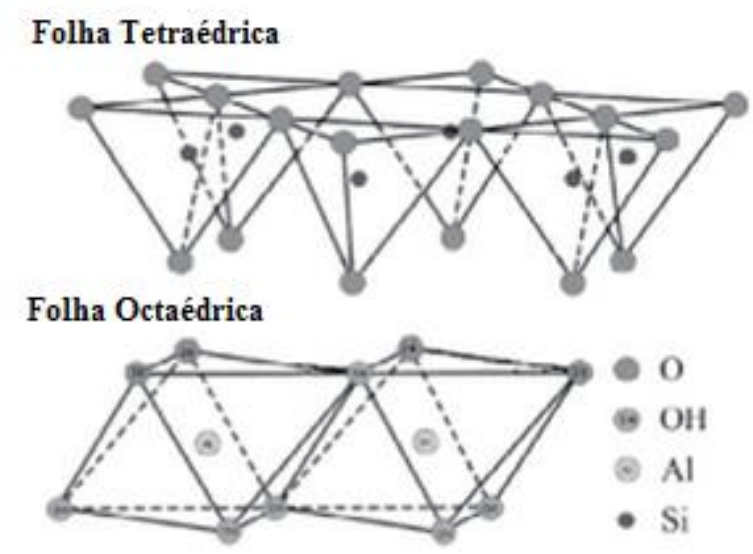

Figura 2.1 - (a) Representação esquemática das folhas tetraédricas e octaédricas (adaptado de Grim, 1962).

Os argilominerais mais comumente encontrados nos solos e que são importantes no processo de expansão estão descritos a seguir de acordo com Santos (1989):

\subsubsection{Grupo da Caulinita}

São os minerais formados pelo empilhamento de uma lâmina de tetraedros de Si e uma lâmina de octaedros de $\mathrm{Al}$, denominada de 1:1, dando como fórmula química $\mathrm{Al}_{2} \mathrm{Si}_{2} \mathrm{O}_{5}(\mathrm{OH})_{4}$. A ligação entre essas duas lâminas é iônica entre o oxigênio situado no ápice da lâmina de tetraedros e o $\mathrm{Al}$ da lâmina octaédrica.

As camadas 1:1 são seguras por pontes hidrogeniônicas entre os oxigênios da camada tetraédrica e hidroxilas da camada octaédrica. Essas pontes promovem uma ligação forte entre as camadas 1:1. Este fato pode corroborar a não expansibilidade deste argilomineral e também à ausência de troca de materiais entre as camadas 1:1.

As distâncias entre os planos atômicos que se repetem é de $7 \AA$, não apresentando modificações sob tratamentos comuns, o que facilita a identificação desse argilomineral.

A caulinita mostra normalmente uma morfologia hexagonal, apresenta baixa superfície específica e uma CTC que varia na faixa de $1-10 \mathrm{cmol}_{\mathcal{C}} / \mathrm{kg}$. A CTC é altamente dependente do $\mathrm{pH}$, o que parece mostrar que, predominantemente, as cargas da caulinita são desenvolvidas em função do pH e não são o produto de substituições isomórficas na estrutura. Essas cargas se desenvolvem nas bordas quebradas do mineral. Em geral, a caulinita é uma argila de baixa atividade coloidal, com baixa plasticidade e também baixa expansão e contração (Muggler et al., 2005). 


\subsubsection{Grupo das Esmectitas}

São minerais de camadas 2:1, formados pelo empilhamento de duas lâminas tetraédricas, e uma lâmina octaédrica. As ligações que mantêm as lâminas juntas nas camadas 2:1 são iônicas dos oxigênios localizados no ápice ligados aos $\mathrm{Si}$ dos tetraedros com o $\mathrm{Al}$ da lâmina dos octaedros, como nas unidades 1:1.

Os minerais principais 2:1 apresentam cargas elétricas de superfície que são originárias, principalmente, de substituições isomórficas nas camadas tetraédricas ou octaédricas. A montmorilonita, principal exemplo das esmectitas, tem suas cargas desenvolvidas a partir de substituições isomórficas que ocorrem principalmente na lâmina octaédrica. Nessa camada, o $\mathrm{Mg}$ substitui de forma isomórfica o Al e causa um desbalanço de carga. Isso possibilita a atração de cátions para neutralizar a carga desenvolvida (Muggler et al., 2005).

Entretanto, quando a montmorilonita é comparada com outras argilas 2:1, como as vermiculitas, apresenta baixa densidade de cargas na superfície entre as unidades cristalográficas (planos basais). Assim, a pequena força de atração entre os planos basais permite que moléculas de água e outras substâncias penetrem e provoquem uma grande expansão do material (Muggler et al., 2005).

A montmorilonita apresenta uma alta superfície específica, com a CTC variando entre de 80$120 \mathrm{cmolc} / \mathrm{Kg}$ e é praticamente independente do $\mathrm{pH}$. Ou seja, a maioria das cargas origina-se da substituição isomórfica (carga permanente). Por estas características, a montmorilonita é uma argila de atividade alta, apresentando alta plasticidade e uma capacidade muito grande de expansão e contração, o que provoca muitas fissuras no solo quando seco.

\subsubsection{Grupo das Vermiculitas}

São minerais do tipo 2:1, oriundos da alteração direta das micas. Sua estrutura consiste de lâminas de mica separadas por camadas de moléculas de água. A substituição do Si pelo Al na camada de tetraedros resulta em cargas líquidas negativas. Essas cargas são neutralizadas pelos cátions que estão entre as camadas em conjunto com as moléculas de água (Muggler et al., 2005).

A espessura básica é de $14 \AA$, podendo variar de acordo com o cátion permutável presente e o estado de hidratação do cristal. Devido à densidade de carga, a vermiculita não se expande de forma expressiva, chamada, portanto, de mineral de expansibilidade limitada. 
A vermiculita também é uma argila de alta atividade, com CTC de 100-160 cmolc/Kg, que é maior que da montmorilonita pela densidade de cargas maior. A superfície específica é semelhante à da montmorilonita na faixa de $600-800 \mathrm{~m}^{2} / \mathrm{g}$.

A vermiculita tem expansão menor quando comparada à montmorilonita e, praticamente, não expande se saturada com $\mathrm{K}^{+}$ou $\mathrm{NH}^{4+}$. Este fato pode ser explicado pela alta especificidade das posições internas ocupadas nas camadas por esses cátions. Eles são “presos” pela vermiculita e não são trocados facilmente (Muggler et al., 2005).

\subsubsection{Grupo das Micas e Ilitas}

Estes minerais são do tipo 2:1, sendo duas camadas tetraédricas e uma camada octaédrica. As substituições de cátions de cargas diferentes estão localizadas principalmente nas camadas tetraédricas, nas quais em cada quatro tetraedros, três são ocupados por $\mathrm{Si}^{4+}$ e um é ocupado por $\mathrm{Al}^{3+}$. O cátion que é responsável pelo balanceamento de carga, na maior parte das micas é $\mathrm{o} \mathrm{K}^{+}$. A estrutura das micas é mais bem compensada do que as das esmectitas, assim, esse tipo de mineral não permite água interlamelar. As micas tendem a formar grandes cristais, podendo ocorrer em rochas sedimentares na fração argila na forma de ilitas.

As ilitas apresentam uma pequena capacidade de adsorção de água e troca catiônica devida, apenas, às ligações quebradas das extremidades das camadas. Quando ocorre a substituição do silício das camadas de tetraedros por alumínio, as ligações entre as unidades estruturais proporcionadas pelos cátions $\mathrm{K}$ podem ser deficientes permitindo a entrada de água. Se isso acontece, as propriedades das ilitas se aproximam das propriedades das montmorilonitas.

\subsubsection{Grupo das Cloritas}

Estes minerais apresentam estrutura básica semelhante à das micas. No entanto, existe uma camada de brucita $\mathrm{Mg}(\mathrm{OH})$ nos espaços interlamelares, ao invés de cátions trocáveis. Desta forma, o mineral é caracterizado como 2:1:1, com unidade básica apresentando espessura de $14 \AA$.

\subsubsection{Propriedades dos Argilominerais}

De acordo com Frazão e Goulart (1976), a propriedade característica do argilomineral mais importante é a capacidade de troca de cátions (CTC) interlamelares por outros equivalentes, sem alteração na estrutura. Essa propriedade é mais marcante naqueles argilominerais que 
apresentam uma maior carga residual compensada, como as esmectitas e vermiculitas, e menos importante nos minerais de menor carga residual, como as caulinitas.

A CTC é uma característica físico-química que indica a quantidade de íons positivos que um solo é capaz de reter em determinadas condições, e trocar por quantidades estequiométricas equivalentes de outros íons de mesmo sinal. A propriedade de troca de cátions se deve ao excesso de cargas negativas na estrutura dos trocadores. Isto leva a uma compensação por íons trocáveis de carga contrária (Raij, 1969).

Grim (1953) define três causas principais para a ocorrência da capacidade de troca de cátions: (1) quebra das ligações nas bordas dos minerais; (2) substituição isomórfica, onde elementos podem substituir o alumínio e o silício nas estruturas cristalinas básicas dos argilominerais, que são os tetraedros e os octaedros; (3) dissociação de radicais $\mathrm{OH}$ expostos nas arestas das partículas, que tendem a se desligar e ir para a solução, liberando cargas negativas, devido ao aumento do $\mathrm{pH}$. O surgimento dessas cargas negativas que dependem do $\mathrm{pH}$ é chamada de CTC dependente do pH, ou CTC variável.

A CTC média pode ser apresentada para cada grupo de argilomineral, como mostrado na Tabela 2.2 (Grim, 1953).

Tabela 2.2 - Capacidade de troca de cátions de minerais de argila (Grim, 1953).

\begin{tabular}{lc}
\hline \multicolumn{1}{c}{ Argilomineral } & CTC $(\mathbf{m e q} \mathbf{1 0 0 g})$ \\
\hline Caulinita & $3-15$ \\
Haloisita 2H2O & $5-10$ \\
Haloisita 4H2O & $40-50$ \\
Montmorilonita & $80-150$ \\
Ilita & $10-40$ \\
Vermiculita & $100-150$ \\
Clorita & $10-40$ \\
Sepiolita - Atapulgita - Paligosquita & $20-30$ \\
\hline
\end{tabular}

Outra propriedade dos argilominerais que se destaca é a adsorção de água dentro do seu retículo cristalino, sem alteração da sua estrutura. Isso ocorre devido à estrutura foliar permitir que as moléculas de água penetrem nos espaços interlamelares sem interação química com a estrutura básica. 
O fenômeno da adsorção pode ser entendido como a retenção de água na superfície das partículas sólidas que são envolvidas por um filme. A adsorção é proveniente da força resultante de atração e repulsão entre as moléculas de água e a superfície sólida dos minerais de argila. Essa capacidade de adsorção de água é bastante variável entre os grupos de argilominerais, sendo maior nas esmectitas. Já a caulinita apresenta adsorção extremamente limitada. Não apenas água, mas também substâncias orgânicas podem ser adsorvidas pelos argilominerais.

De acordo com Mitchell (1993) a adsorção de cátions ocorre na superfície específica das partículas de argila que são carregadas negativamente. Para neutralizar essa eletronegatividade, são necessários cátions em excesso que produzam concentrações elevadas para igualar as concentrações em toda a superfície. A tendência de dispersão devido à difusão e à atração eletrostática oposta conduzem a uma distribuição do íon na superfície da partícula de argila em suspensão (Figura 2.2). Os ânions, no entanto, são excluídos por um campo de forças negativas da partícula. A superfície carregada e a carga distribuída na superfície da argila são denominadas de dupla camada elétrica, ou dupla camada difusa.
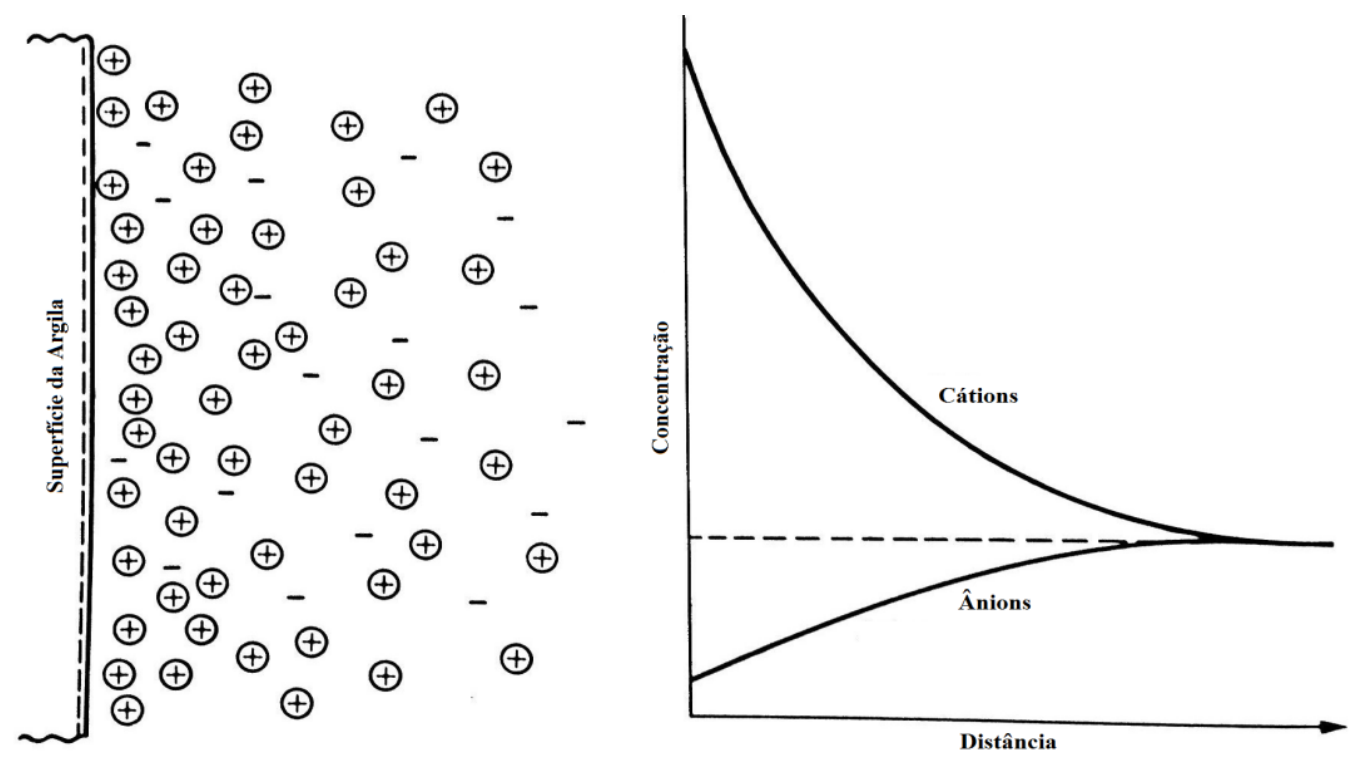

Figura 2.2 - Distribuição de íons adjacentes na superfície da argila de acordo com o conceito da dupla camada difusa (Adaptado de Olphen, 1963).

A capacidade de adsorção leva consequentemente à expansão do retículo na direção do empilhamento das camadas básicas. Assim, os mesmos minerais que apresentam capacidade de adsorção de água, também apresentam capacidade de expansão. 
Existem, também, as forças de ligação que influenciam diretamente no comportamento das partículas, as quais podem ser divididas em forças de atração e forças de repulsão. As cargas elétricas de um dado solo que se estabelecem na superfície das partículas estão em relação direta com as áreas dessas superfícies. Portanto, quanto maior a superfície específica, maior a tendência para o comportamento das partículas ser controlado pelas forças superficiais.

De acordo com Olphen (1963), a atração entre as partículas se deve às forças de Van der Waals, que são as forças que ocorrem em todas as moléculas de água adsorvidas numa partícula. A grandeza dessa força depende do tamanho e geometria das partículas, sendo independente das características da camada dupla e inversamente proporcional à distância entre as partículas. A repulsão é essencialmente de natureza elétrica, onde ocorrem cargas de mesmo sinal. Essas forças são originadas pela interpenetração das camadas difusas de cada uma das partículas, sendo a intensidade dependente da espessura dessas camadas.

De acordo com Snethen et al. (1975) os argilominerais que exibem expansão ou contração considerável são chamados de argilominerais expansivos, e incluem a montmorilonita, as vermiculitas, a clorita, e combinações misturadas desses materiais. A haloisita, que é constituinte hidratado do grupo da caulinita, também pode apresentar propriedades expansivas. A Tabela 2.3 apresenta alguns dados representativos de expansão livre para os argilominerais mais comuns (Grim, 1962).

Tabela 2.3 - Valores típicos de expansão livre para argilominerais comuns (Grim, 1962).

\begin{tabular}{lc}
\hline \multicolumn{1}{c}{ Argilomineral } & Expansão Livre (\%) \\
\hline Montmorilonita - Na & $1.400-2.000$ \\
Montmorilonita - Ca & $45-145$ \\
Vermiculita $* *$ & - \\
Clorita $* *$ & - \\
Ilita & $60-120$ \\
Caulinita & $5-60$ \\
Haloisita & 70 \\
\hline \multicolumn{2}{c}{ *xpansão livre variável, e depende do tamanho e cristalização. }
\end{tabular}




\subsection{Mecanismos de Expansão}

O comportamento de um solo expansivo está associado a uma instabilidade volumétrica, em que as forças de atração entre as partículas são capazes de transferir água de um ponto a outro ponto do solo. Este fato implica em um desequilíbrio na umidade natural do entorno.

Os mecanismos de expansão dependem de vários fatores, tais como, o tipo de argilomineral, disponibilidade de água, tipo e quantidade de cátions trocáveis, e a interação entre a água e os cátions presentes. De acordo com Taylor e Smith (1986), esses mecanismos são caracterizados como expansão mecânica e/ou expansão físico-química.

Estes mecanismos podem ser explicados, também, com base nas forças existentes entre as partículas e as camadas estruturais. Os mecanismos físico-químicos de expansão podem ser intercristalinos ou intracristalinos e osmóticos. A expansão osmótica constitui-se de duas fases, sendo a primeira relacionada à infiltração de moléculas de água entre as camadas estruturais das argilas, ou entre as superfícies planas das partículas adjacentes, tendendo a separá-las. As forças envolvidas durante esta fase são as forças de Van der Waals; interação eletroestática entre as superfícies e os cátions dispersos; e a energia de adsorção das moléculas de água. Na segunda fase, as superfícies das partículas já estão separadas por distâncias superiores a quatro camadas monomoleculares de água, por isso a energia de adsorção torna-se relativamente reduzida, permitindo que a energia de repulsão da dupla camada elétrica se sobreponha. Com a continuação da adsorção de moléculas de água, essa distância tende a aumentar, e com ela as forças de repulsão (Cristelo, 2001).

O autor comenta, ainda, que a expansibilidade intercristalina ocorre quando a absorção de água se faz através das superfícies externas dos cristais dos minerais argilosos e dos vazios entre esses cristais. A água absorvida forma camadas monomoleculares sucessivas sobre as partículas dos minerais argilosos, afastando as unidades estruturais e as próprias partículas. A expansão intracristalina é justificada pelo desequilíbrio entre as forças atrativas que ligam as camadas estruturais (inferiores) e as forças atrativas responsáveis pela absorção de água.

A expansão mecânica está relacionada às forças de descompressão, ou seja, às ações antrópicas ou naturais que provocam relaxamento na pressão, gerando uma pressão negativa na água presente nos poros com a mesma grandeza da pressão inicial (Pereira, 2004). A expansão físico-química agrupa três fatores básicos: atração das partículas de argila, hidratação de cátions e repulsão osmótica. 


\section{Atração das partículas de argila}

As ligações atrativas de superfície entre os minerais de argila, entre esses minerais e a água, e entre eles e os cátions, são provocadas devido a forma do mineral e a sua estrutura cristalina interna. As forças que atraem cátions e moléculas polares (como a água) são oriundas das cargas elétricas negativas da superfície das partículas de argila. Essas cargas atuam como força de fixação de moléculas de água na camada dupla. $\mathrm{O}$ volume na camada dupla aumenta até que ocorra uma variação de volume suficiente na massa de solo, pois a força de adsorção de água pela partícula diminui com a distância relativa à superfície das mesmas.

Mitchell (1993) comenta que a atração e fixação de moléculas ocorrem através da ligação do hidrogênio das moléculas água à superfície do mineral e da atração dipolo-dipolo das moléculas de água.

\section{Hidratação de cátions}

A superfície negativa das partículas de argila atrai cátions que anulam sua carga negativa. No entanto, alguns cátions após neutralizarem as cargas negativas das partículas, ainda permanecem com certa quantidade de carga não neutralizada. Dessa forma, essa parcela de carga positiva remanescente atrai moléculas de água, que por meio de seus polos positivos atraem outras moléculas.

Na hidratação de cátions ocorrem estas forças de atração sobre as moléculas de água e um aumento de raio iônico dos cátions, que por sua vez, promovem um aumento de volume da massa de solo (Presa, 1984).

\section{Repulsão osmótica}

A repulsão osmótica resulta dos gradientes de pressão desenvolvidos nas camadas duplas devido à variação na concentração iônica nestas camadas. Quando o sistema argila-águacátion entra em contato com a água de menor concentração iônica, a camada dupla atua como uma membrana semipermeável. Dessa maneira, a água tende a passar esta membrana para igualar, por osmose, as concentrações dos dois lados da membrana. Isto resulta no aumento da espessura da camada dupla, e consequentemente, do volume de massa de solo. 


\subsubsection{Fatores que Afetam a Expansão}

De acordo com Snethen et al. (1975), os fatores que influenciam a expansão podem ser divididos em fatores intrínsecos e condições ambientais. $\mathrm{O}$ autor cita como fatores intrínsecos que afetam o comportamento de materiais expansivos a composição do solo; tamanhos das partículas dos minerais de argila; densidade seca; arranjo dos grãos; água nos poros; permeabilidade; cimentação e efeitos diagenéticos. Além desses fatores, o autor cita também, o confinamento, tempo e temperatura, que não são fatores intrínsecos, porém, influenciam nas características dos outros fatores aqui considerados. As características desses fatores são:

Composição do solo: inclui o tipo de solo e, consequentemente, o tipo de argilomineral, bem como, a superfície específica. Como visto anteriormente, o tipo de argilomineral determina se o material expande ou não.

Tamanho das partículas dos grãos de argila: afeta a mudança de volume pela entrada de moléculas de água na dupla camada. Geralmente, partículas de tamanho pequeno resultam em grandes áreas de superfície específica, que permitem espessuras consideráveis pela entrada de água na dupla camada. A montmorilonita, por exemplo, ocorre como pequenas partículas que podem ser considerada como colóides. Numa dispersão completa, em condições defloculadas, podem estar presentes tamanhos de outras ordens. Por outro lado, a caulinita pode apresentase em tamanhos maiores, como sendo uma partícula de silte. Portanto, os tamanhos dos minerais de argila e as respectivas superfícies específicas são inversamente proporcionais, visto que, a superfície específica aumenta com a diminuição do tamanho das partículas.

Densidade seca: é um fator importante para determinar a magnitude da variação de volume. A expansão, ou pressão de expansão de materiais potencialmente expansivos aumenta com o aumento da densidade seca para teores de umidade constante. Isto ocorre por uma razão simples, onde os valores elevados de densidade resultam em um espaço menor entre as partículas, ou seja, redução no índice de vazios, causando melhor interação entre as mesmas. A interação entre as partículas, ou mais precisamente, interação das moléculas de água na dupla camada, resultam em forças de repulsão osmótica elevadas, e assim maior variação de volume. Sendo que este fato pode ser considerado para amostras indeformadas e deformadas. A densidade seca também tem influência indireta sobre outros parâmetros intrínsecos, como por exemplo, a compactação de solo que influencia no arranjo dos grãos. Snethen et al. (1975) comenta que Pacey (1956) e Seed e Chan (1959) verificaram a influência do efeito da compactação em baixos teores de umidade, e concluíram que os arranjos dos grãos 
apresentam-se menos orientados. Já para teores de umidade maiores, os arranjos dos grãos mostram melhor orientação (Figura 2.3).

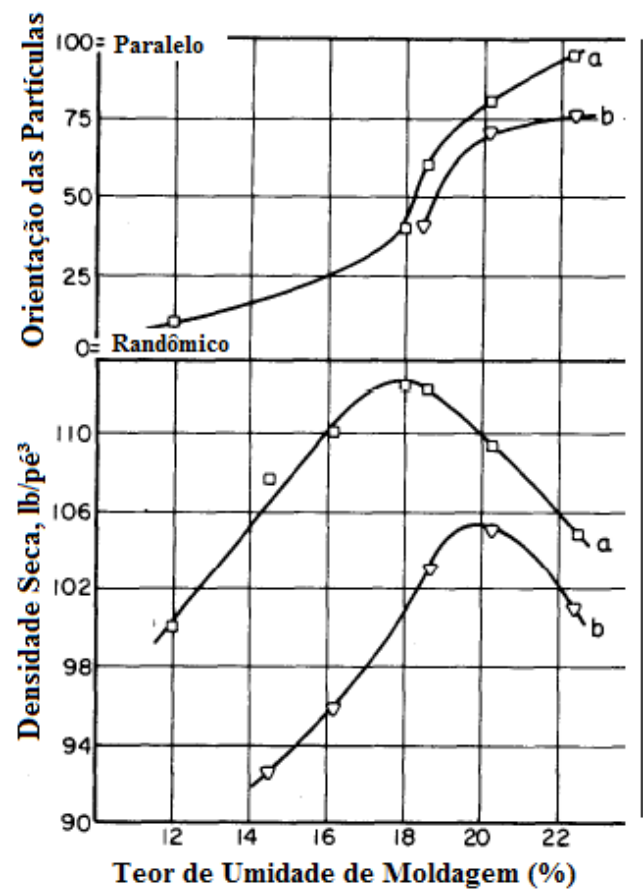

(a)
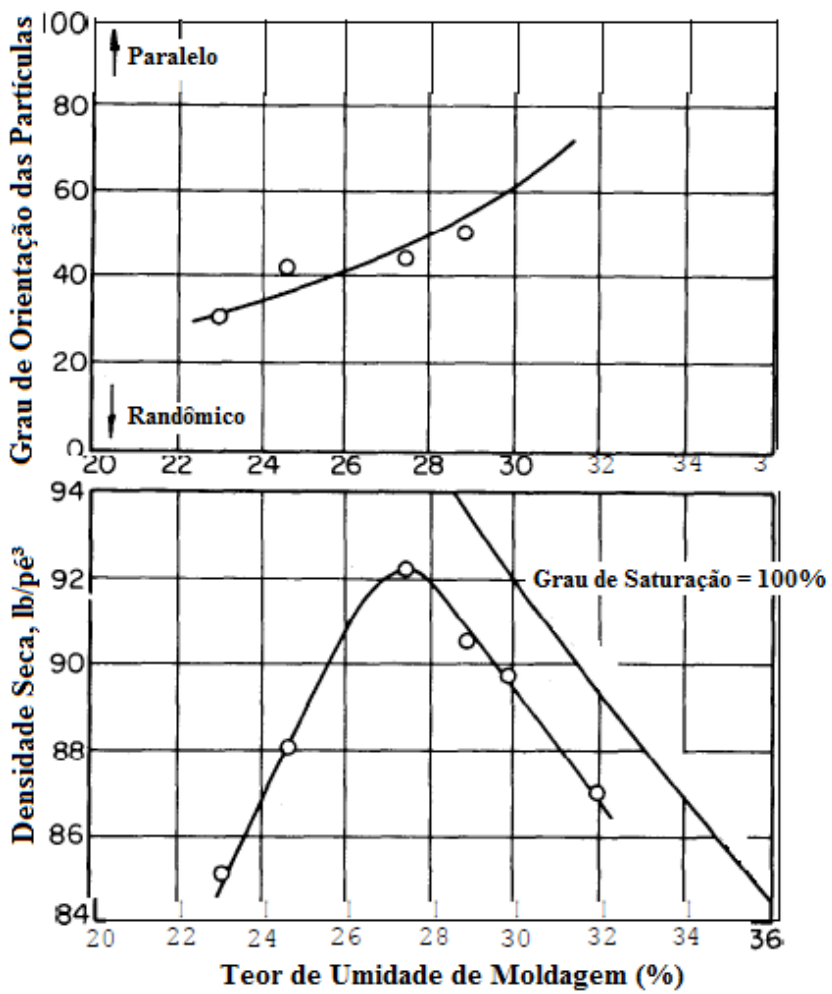

(b)

Figura 2.3 - Teor de umidade moldado versus densidade seca e orientação das partículas: (a) Argila de Boston (Pacey, 1956); (b) Amostras de caulinita compactadas (Seed e Chan, 1959).

Arranjo dos grãos: refere-se à orientação ou arranjo espacial das partículas constituintes. No caso de sedimentos argilosos e rochas, os grãos consistem de arranjos de minerais de argila intercalados com outros componentes minerais não expansivos. O tipo de arranjo do argilomineral influencia a variação de volume, tanto na direção vertical, quanto na lateral. Os grãos de sedimentos argilosos e rochas são complexos, variáveis e difíceis de serem observados. Argilominerais intercalados, geralmente, ocorrem em qualquer aglomeração ou em arranjos não aglomerados.

Água nos poros: a variação de volume é diretamente influenciada pela quantidade de água disponível nos vazios (poros) do solo, portanto, as propriedades da água têm significativa influência no comportamento expansivo. Inicialmente, a variação de volume de solos expansivos se dá pela hidratação dos argilominerais ou, mais precisamente, pela adsorção das moléculas de água na superfície exterior e interior dos argilominerais, a fim de balancear a deficiência de cargas elétricas nas partículas. O grau de hidratação é influenciado pela 
quantidade e tipo de íons adsorvidos nas partículas, e pelo tipo e quantidade de íons nos fluidos dos poros. Os fluidos presentes nos poros contêm concentrações elevadas de cátions, bem como, sais solúveis, os quais tendem a reduzir a magnitude da variação de volume em solos potencialmente expansivos. Por outro lado, fluidos que apresentam concentração iônica baixa podem liberar cargas balanceando cátions e agentes cimentantes, o que torna o solo mais susceptível a variação de volume.

Permeabilidade: é um fator que influencia a variação de volume de acordo com o tempo. A permeabilidade é função do teor de umidade inicial, densidade seca, e do arranjo dos grãos do solo. Para solos compactados, a permeabilidade é elevada para baixos teores de umidade e densidade seca; diminui para valores relativamente constantes quando se trabalha próximo a umidade ótima. Para teores de umidade acima do ótimo, a permeabilidade é praticamente constante. A razão para a baixa permeabilidade com teores de umidade próximo da ótima e densidades seca máxima é o tamanho dos vazios disponíveis para a movimentação da umidade, ou seja, o espaçamento entre as partículas. Teores de umidade ótima permitem a interação da água com camada dupla, minimizando os vazios necessários para a movimentação da umidade.

Temperatura: a influência da temperatura é limitada aos efeitos sobre a viscosidade e a gravidade específica da água adsorvida. $\mathrm{O}$ aumento da temperatura tende a comprimir a água da dupla camada. No entanto, baixas temperaturas resultam na expansão da dupla camada. $\mathrm{O}$ ponto mais importante é a influência da temperatura na movimentação da umidade, tanto em forma de líquido ou de vapor, como resultado dos gradientes térmicos no interior da massa de solo. O vapor de água a uma temperatura mais elevada é capaz de migrar para uma região mais fria em um esforço a fim de balancear a energia térmica do sistema. A movimentação da umidade por um gradiente térmico ocorre como um filme termo osmótico análogo ao fluxo eletro osmótico.

Cimentação: reflete uma ação adesiva do cimento mineral que reveste e vincula as partículas com as rochas sedimentares. A presença ou ausência desses cimentos pode determinar se um material pode ser classificado com uma rocha ou um sedimento. A presença do cimento produz dois efeitos: o desenvolvimento de conexões entre os pontos de contato, o que diminui a probabilidade das partículas adjacentes se deslocarem; e o revestimento de partículas individuais, que reduz a capacidade de absorção de água dos minerais. 
Efeitos Diagenéticos: mudanças nas condições de sobre carregamento, ou de ambientes de água subterrânea alteram as características físicas e termo físicas de materiais, denominando esses efeitos de fatores diagenéticos. Esses fatores refletem na ligação interpartículas devido a recristalização dos contatos entre os argilominerais sob elevadas condições de carregamento, ou pela cimentação das partículas como um resultado da precipitação de agentes cimentantes. Em geral, a diferença no comportamento de solos expansivos entre condições deformadas e indeformadas estão relacionadas com a presença de ligações diagenéticas.

Textura: Pereira (2004) comenta que Le Roux (1976) define a textura de uma rocha como sendo a forma, dimensão, e a disposição dos minerais agrupados em conjunto no interior da rocha. Dessa forma, várias características condicionam essa textura, dentre as que se destacam: a cristalinidade; a forma e dimensão das partículas constituintes; tamanho das partículas; ligação entre os minerais; presença e orientação entre os vazios; trincas e fraturas. Todas essas características podem influenciar no comportamento de materiais potencialmente expansivos, visto que, estão relacionadas com a cristalização dos minerais que constituem os materiais argilosos.

Coleman (1962) comenta que a redução na sucção pode induzir o colapso ou expansão do solo dependendo da estrutura e porcentagem de argila. Uma estrutura floculada pode ser associada ao colapso. Altas porcentagens de argila com estrutura dispersa associam-se ao comportamento expansivo. Materiais intermediários podem exibir comportamentos que dependem do nível de tensões aplicadas nas quais ocorrem as inundações.

Vilar (1992) comenta que os problemas de expansibilidade não ocorrem apenas em solos. As características expansivas são observadas em diversos tipos de rochas, destacando-se nas sedimentares, como os siltitos, argilitos, folhelhos, margas e calcários, cujas composições incluem argilominerais expansivos. A ocorrência desses materiais está associada à presença dos argilominerais da família das esmectitas, principalmente as montmorilonitas.

Em solos compactados, os fatores que podem influenciar na expansão podem ser divididos em dois grupos: o primeiro refere-se aos aspectos que determinam o potencial de expansão e que depende da natureza das partículas, representado pelo tipo e quantidade de argila no solo; o segundo grupo refere-se à magnitude da expansão, que depende das condições de compactação e do ambiente. Este segundo grupo leva em consideração a estrutura do solo, a massa específica seca, o método e o grau de compactação, o teor de umidade inicial, a 
disponibilidade de água, assim como, a concentração dos eletrólitos e a sobrecarga atuante (Seed et al., 1962).

Frazão e Goulart (1976) basearam-se em Brekke (1965) para analisar os fatores que influenciam na expansão. Os diversos fatores dividem-se em internos e externos. Os fatores internos estão ligados ao tipo de argilomineral, à fração de argila, ao tipo de cátion trocável, à concentração de íons, ao tamanho e dimensão das partículas de argilomineral, à densidade da argila no início do processo de expansão, ao teor de umidade inicial e à existência ou não de cimentação diagenética. Ou seja, são os fatores que determinam a variação volumétrica em função da variação de umidade, e que estão relacionados com a natureza e o arranjo das partículas. Os fatores externos relacionam-se com a disponibilidade de água e acesso ao argilomineral, concentração e natureza do íon na água, aumento de volume ou não no processo de expansão e eventual contrapressão.

De acordo com Ferreira (1988), para que um solo seja potencialmente expansivo é necessário que esteja na condição não saturada. Dessa maneira, seu teor de umidade está em equilíbrio com a evaporação à superfície do terreno, com a transpiração da vegetação local e a ascensão capilar da água. Quando este sistema é interrompido temporariamente a atividade expansiva do solo se manifesta, seja pela ação antrópica ou por fatores naturais.

Outro fator que pode afetar o comportamento expansivo é o histórico de tensões em uma porção de solo. O aumento da tensão aplicada a um solo argiloso permite a drenagem de água sob efeito do aumento da pressão neutra, em consequência disso a área de contato entre as partículas é aumentada, reduzindo a espessura da camada de água adsorvida o que proporciona o rearranjo das partículas. Se este incremento de pressão for retirado e a água retornar ao solo, o fenômeno de expansão do volume pode ocorrer, visto que a camada adsorvida retoma à sua espessura inicial. Porém, partindo do princípio de que parte dessa água que estaria sob efeito da pressão neutra em excesso foi expulsa, houve uma alteração da posição relativa das partículas que passaram a ocupar espaços anteriormente ocupados pela água. Neste momento, essas partículas não retomarão a posição inicial, pois uma parcela da deformação é irreversível.

Cardoso et al. (2012) realizou um estudo em escala micrométrica do comportamento volumétrico de solos argilosos compactados no qual foi avaliado o efeito da compactação levando em consideração a variação de energia e teores de umidade. Foi constatado que a 
variação do teor de umidade influencia na interação entre as cargas elétricas da água e dos minerais argilosos do solo. Do mesmo modo, diferentes estruturas do solo são resultantes da quantidade de água adicionada ao material para o processo de compactação. Foi verificado que a amostra em seu estado mais úmido apresenta vazios de menores dimensões em relação às amostras compactadas mais secas.

Os autores comentam, ainda, que os vazios de pequenas dimensões existentes nos torrões de argila são os microporos, e os vazios maiores entre esses torrões são os macroporos. Portanto, a maior ou menor importância da macroestrutura no solo permite explicar o seu comportamento volumétrico quando sujeito a carregamentos externos que envolvem variação de tensão e de sucção. A importância da microestrutura permite explicar a sensibilidade destes materiais com relação à absorção de água (molhagem), que pode ser traduzida em variações de volume dos torrões devido ao aumento no teor de umidade. Essa variação de volume pode ter ou não caráter irreversível, visto que, depende do arranjo das partículas e, portanto, da dimensão dos macroporos.

Cardoso et al. (2012) ressaltam que estudos recentes de Romero et al. (1999) e Thom et al. (2007) confirmam que as variações volumétricas em solos argilosos compactados devido à ação mecânica ocorrem essencialmente pela variação de volume dos vazios de maiores dimensões.

Os autores ilustram na Figura 2.4 a diferença de comportamento de amostras compactadas no trecho úmido e no trecho seco da curva de compactação a partir de dados obtidos na curva de distribuição de poros, a qual se verifica que os poros de menor dimensão com estrutura floculada são de amostras compactadas no trecho úmido. Já no trecho seco, espera-se encontrar vazios de maior dimensão, tratando-se de uma estrutura dispersa. É possível notar, também, que a distribuição de poros para a amostra compactada no trecho seco apresenta dois diâmetros predominantes, que são representados pelos dois picos no gráfico. Na amostra compactada no trecho úmido existe, praticamente, apenas um diâmetro, apesar de existirem também, um intervalo de diâmetro muito semelhante em torno de $100 \mathrm{~mm}$. Para tanto, a distribuição de vazios de pequenas dimensões é independente do teor de umidade de compactação. 

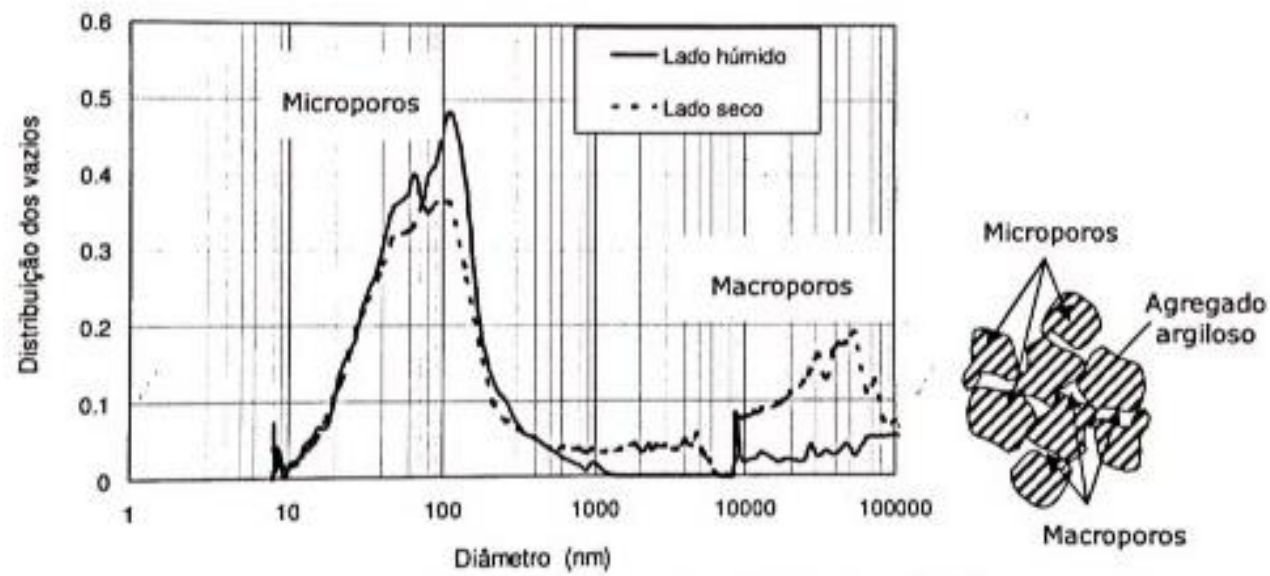

Figura 2.4 - Porosimetria por intrusão de mercúrio de amostras de solo argiloso compactado com o mesmo índice de vazios e diferentes teores de umidade (Adaptado de Cardoso et al., 2012)

Ainda relacionando-se a distribuição dos poros em solos argilosos compactados, Cardoso (1995) comenta que os microporos caracterizam a estrutura interior dos agregados e os macroporos constituem os vazios entre os agregados. Os microporos podem se encontrar interconectados e se ligando aos macroporos isolados.

Mesmo que possa ocorrer uma predominância dos dois tipos de poros, existe, normalmente, uma graduação entre os mesmos. Essa graduação pode ser adotada seguindo o mesmo sentido da graduação granulométrica. Por exemplo, a adição de água no processo de compactação em solos com alta porcentagem de finos proporciona o agrupamento das partículas finas e formação de grumos de até 3 a 4 mm de diâmetro (Camapum de Carvalho e Leroueil, 2004).

Partindo do princípio de que os grumos são constituídos de microporos e entre estes se formam os macroporos, solos finos compactados no ramo seco mantem certa estabilidade originando os macroporos que se formam entre eles. Este fato ocorre devido à sucção presente no interior dos grumos no processo da compactação. Já em solos compactados no ramo úmido, a quantidade de água é mais elevada e, portanto, há uma redução na sucção fazendo com que os grumos se tornem mais deformáveis e/ou desagregáveis originando, assim, uma distribuição de poros melhor graduada (Camapum de Carvalho e Leroueil, 2004).

Alguns tipos de solos compactados e naturais apresentam um comportamento associado de colapso e expansão quando inundados. Quando estão sob ação de cargas externas não significativas e sob inundação, ocorre expansão no arranjo de partículas elementares que se localizam dentro dos agregados; isto tende a manter a estrutura original. Quando a tensão 
externa aumenta, quebram-se os vínculos, ocorrem deslocamentos nos contatos entre as partículas e deformam-se os agregados. Dessa forma, os vazios entre os agregados e entre os grãos são ocupados por grãos de areia (Ferreira, 1995).

Os fatores extrínsecos do solo também se relacionam com a expansão, como a disponibilidade de água no sistema. Mudanças sazonais de umidade, ao longo do ano, estão vinculadas ao clima, enquanto as oscilações periódicas de umidade, na superfície do terreno, dependem da relação precipitação/evapotranspiração. A evapotranspiração, por sua vez, está condicionada ao tipo e à exuberância da vegetação, além dos fatores ligados à atmosfera, que são umidade, velocidade do vento e temperatura do ar. 


\subsection{Solos Não Saturados}

Segundo Vilar (2000), os solos não saturados são aqueles que constituem ar em seus vazios que varia de acordo com o grau de saturação. O comportamento desses solos depende de vários fatores que são influenciados pelas fases que o compõe. A seguir, são apresentadas as características principais e o comportamento dos solos não saturados.

\subsubsection{Fases Constituintes do Solo Não Saturado}

De acordo com Lambe e Whitman (1969), o solo não saturado é constituído por um sistema trifásico, o qual compreende uma fase sólida (partículas minerais), uma fase líquida (a água) e uma fase gasosa (ar). Uma quarta fase independente foi introduzida por Fredlund e Morgensten (1977) referente à interface ar-água conhecida como membrana contrátil.

Essa membrana contrátil, que é a interface ar-água, é caracterizada por uma propriedade conhecida como tensão superficial. Essa tensão é um fenômeno resultante de forças intermoleculares de tração, e tem significativa importância na análise do comportamento de retenção de água no solo.

\subsubsection{Potencial de Água no Solo}

O estado de energia da água no solo é a soma de duas energias, a cinética e a potencial. Porém, como a velocidade de migração da água no interior do solo é muito baixa, a quantificação da energia cinética perde sua importância diante da energia potencial. Assim, essa energia potencial pode caracterizar o estado de energia da água do solo (Reichardt, 1985).

Bolt e Miller (1958) definiram o potencial total da água do solo como a mínima energia por unidade de massa, necessária para deslocar um volume infinitesimal de água de um estado de referência arbitrado, até outro ponto da fase líquida que permaneça em repouso.

A função termodinâmica energia livre de Gibbs descreve o estado de energia do solo, que é denominado de potencial total da água do solo. Para um sistema fechado, essa função pode ser definida como (Rhom, 2004):

$$
G=U+P . V-T . S
$$

Onde, 
$U=$ energia interna do sistema

$P=$ pressão externa

$V=$ volume

$T=$ temperatura

$\mathrm{S}=$ entropia

No estudo da relação solo-água, o potencial total da água do solo é denominado de $\varphi$ ou $\Phi$. Sendo, a diferença de pressão entre o ar e a água (Baver et al. (1972).

$$
\varphi=\varphi_{p}+\varphi_{m}+\varphi_{o}+\varphi_{t}+\varphi_{y k}
$$

Onde,

$\varphi_{p}=$ componente de pressão

$\varphi_{m}=$ componente matricial

$\varphi_{o}=$ componente osmótico

$\varphi_{t}=$ componente de temperatura

$\varphi_{y k}=$ Outros componentes

Essas componentes influenciam pela quantidade na qual realizam o trabalho contra qualquer uma das combinações que podem ocorrer. A componente de pressão ocorre quando a pressão externa que atua sobre o solo é diferente da pressão atmosférica. Pode-se referir a este potencial, também, como potencial pneumático, quando o ponto do solo considerado situa-se acima do nível d’água, e a pressão do gás é diferente daquela do ponto de referência (Rohm, 2004).

Segundo o mesmo autor, a componente matricial é um potencial de pressão e resulta do efeito combinado da ação de forças capilares e efeitos de adsorção que surgem devido à interação entre a água e as partículas minerais (matriz) que compõem o solo.

A componente osmótica é um potencial negativo que está relacionada com a concentração de química da água do solo. Esta componente pode ser considerada desprezível quando os solos apresentarem alto teor de umidade. Do contrário, para baixos teores de umidade, ou quando a concentração salina é significante, a importância desta componente é considerada (Reichardt, 
1985). O potencial osmótico tem influência expressiva no comportamento deformacional dos solos. Portanto, não pode ser desconsiderado em problemas de solos não saturados.

A componente de temperatura representa a variação parcial do potencial químico da água do solo, a qual ocorre devida somente a uma diferença de temperatura entre a água no solo sob um estado considerado e a água no estado padrão de referência. Entretanto, os processos que ocorrem no interior de uma massa de solo são considerados isotérmicos. Quando se adota a temperatura do estado padrão igual à do solo em questão, o potencial térmico iguala-se a zero (Rohm, 2004).

De acordo com Baver et al. (1972), a temperatura tem influência complexa no potencial químico, visto que, o equacionamento dos problemas torna-se mais difícil. Sendo assim, devem-se limitar os estudos a sistemas potenciais isotérmicos, nos quais a influência da temperatura possa ser desconsiderada.

As outras componentes representam as grandezas não consideradas nas demais parcelas. Incluem-se neste termo o potencial gravitacional e o potencial de consolidação, ou sobrecarga. Levando-se em consideração a hipótese de que não ocorre nenhum processo de adensamento e que o ar existente nos poros do solo esteja interligado com a atmosfera, as parcelas correspondentes ao potencial de consolidação e potencial pneumático podem ser desprezadas, assim como, o potencial gravitacional. Neste caso, o potencial total pode ser descrito pela somatória dos potenciais mátrico e osmótico.

Os potenciais mátrico e osmótico podem ser tratados pelas suas pressões correspondentes que são, respectivamente, a sucção mátrica e a sucção osmótica.

\subsubsection{Sucção em Solos}

Sucção é a força com que um elemento poroso absorve a água quando ela está livre para se mover. Essa avidez por água é função das características do material quanto à mineralogia, densidade e umidade. A sucção é expressa, geralmente, como pressão, e as unidades mais utilizadas são kPa, atm e bar e, normalmente, é caracterizada em dois tipos: sucção matricial e sucção osmótica (Marinho, 1998).

Em solos não saturados, a tensão efetiva é controlada pela pressão negativa na água intersticial. Essa pressão é dada pela diferença entre a pressão atmosférica (ou pressão do ar) e pressão na água. 
De acordo com Pereira (2004), a sucção total da água no solo corresponde ao trabalho total das forças de capilaridade, adsorção e osmose, e pode ser definida como a pressão negativa (em relação à pressão do ar) a que se deve submeter à água pura (sem a presença de solutos), para que, ao colocá-lo em contato com o solo através de uma membrana semipermeável, exista equilíbrio.

\subsubsection{Componentes da Sucção do Solo}

De acordo com Fredlund e Rahardjo (1993), a sucção matricial é definida como a pressão negativa da água intersticial devido aos efeitos de capilaridade e as forças de adsorção. A sucção osmótica é a sucção equivalente relacionada à pressão parcial do vapor de água em equilíbrio com a água livre.

Portanto, a sucção total de água no solo é dada pela equação:

$$
\mathrm{S}=\mathrm{S}_{\mathrm{m}}+\mathrm{S}_{\mathrm{os}}=\mathrm{u}_{\mathrm{a}}-\mathrm{u}_{\mathrm{w}}
$$

onde,

$\mathrm{S}$ - sucção total

$\mathrm{S}_{\mathrm{m}}-$ sucção matricial

$\mathrm{S}_{\mathrm{os}}-$ sucção osmótica

$\mathrm{u}_{\mathrm{a}}-$ pressão de ar

$\mathrm{u}_{\mathrm{w}}-$ pressão da água

A sucção matricial é definida pela diferença entre as pressões de ar $\left(\mathrm{u}_{\mathrm{a}}\right)$ e da água $\left(\mathrm{u}_{\mathrm{w}}\right)$ contida nos vazios do solo. Como a pressão de ar, geralmente, é considerada igual à pressão atmosférica $\left(U_{\mathrm{a}}=0\right)$, assim sendo, a sucção mátrica é uma pressão de água negativa. Essa pressão negativa ocorre devido à capilaridade e às forças de adsorção.

A sucção osmótica é incorporada na sucção total quando estão presentes substâncias dissolvidas na água pura, promovendo uma diferença de concentração entre esta água e a água presente nos poros do solo. A água tende a hidratar as moléculas do soluto, para isto, faz-se necessário realizar um trabalho sobre o sistema para retirá-la desta interação com a molécula, evidenciando este potencial negativo. Essa parcela da sucção tem influência apenas em solos finos, dependendo do tipo e concentração dos solutos presentes (Mitchell, 1976). 
Rohm (1993) comenta que Reichardt (1985) relata que em solos com teor de umidade alta a sucção osmótica é desprezível. Sua importância cresce quando a concentração salina é significante, por exemplo, quando o teor de umidade do solo é baixo.

\subsubsection{Curva de Retenção}

Segundo Marinho (2001), a curva de retenção ou curva característica expressa a relação da quantidade de água retida nos poros do material e a pressão que é exercida para remover a água. É representada, usualmente, pela relação entre a sucção e o teor de umidade (volumétrico e gravimétrico), ou pelo grau de saturação.

A curva de retenção (Figura 2.5) pode fornecer várias características importantes do solo, tais como: o ponto de entrada de ar, o grau de pré-adensamento do solo, a faixa de variação da zona capilar, o ponto generalizado da entrada de ar, a capacidade de sucção e a umidade residual.

De acordo com Fredlund et al.. (1996), a curva de retenção pode ser dividida em quatro partes conforme o grau de saturação ao longo da trajetória de secagem.

i) Estágio de saturação total ou zona primária: região da curva em que o solo ainda encontrase saturado;

ii) Estágio de entrada de ar ou zona secundária: região da curva em que o solo começa a apresentar uma terceira fase, a gasosa, onde pode ser determinado o ponto de entrada de ar;

iii) Estágio de transição ou zona terciária: região onde a entrada de ar se intensifica;

iv) Estágio de umidade residual ou zona quaternária: região onde o grau de saturação se torna muito pequeno e o solo apresenta apenas uma umidade residual, nessa fase para se retirar uma quantidade mínima de água se faz necessário uma sucção elevada. 


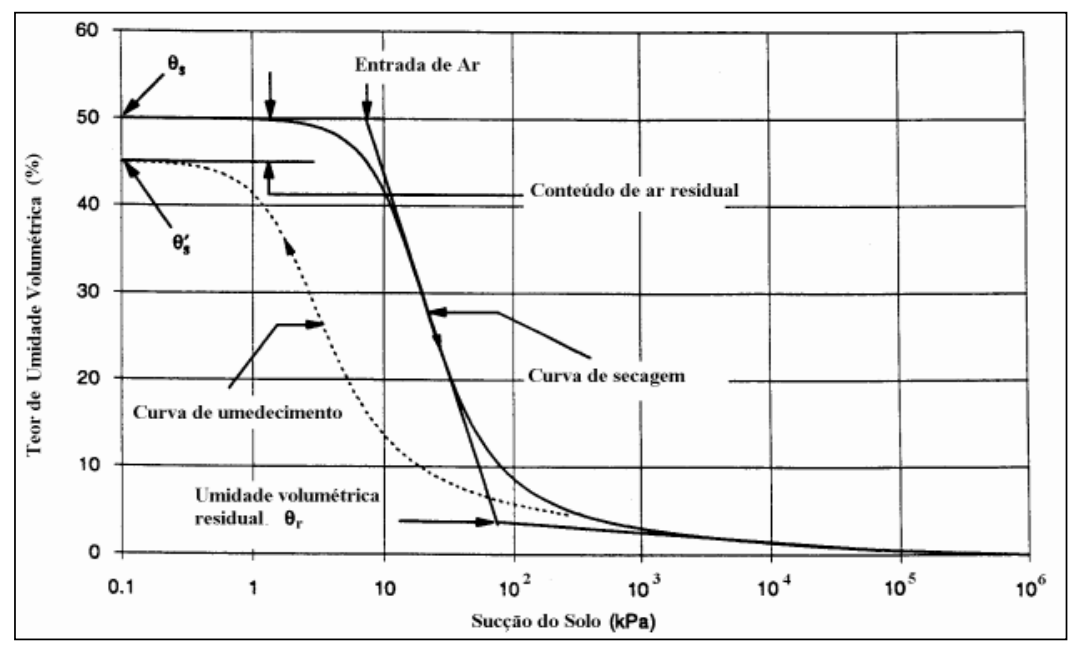

Figura 2.5 - Representação da curva de retenção segundo Fredlund, Xing e Huang (1994), modificado de Pereira (2004).

A forma e a inclinação da curva de retenção dependem diretamente das características inerentes do material, como granulometria, densidade dos grãos e composição mineralógica.

As curvas de retenção diferem para cada tipo de solo. Vilar (2000) apresenta as posições relativas às curvas de retenção para os solos argilosos, siltosos e arenosos. Observa-se na Figura 2.6 que os solos argilosos apresentam maior capacidade de retenção de água para a mesma sucção e pressão de entrada de ar do que para os solos arenosos. Além disso, as modificações pequenas de umidade nos solos argilosos necessitam de extensas variações de sucção.

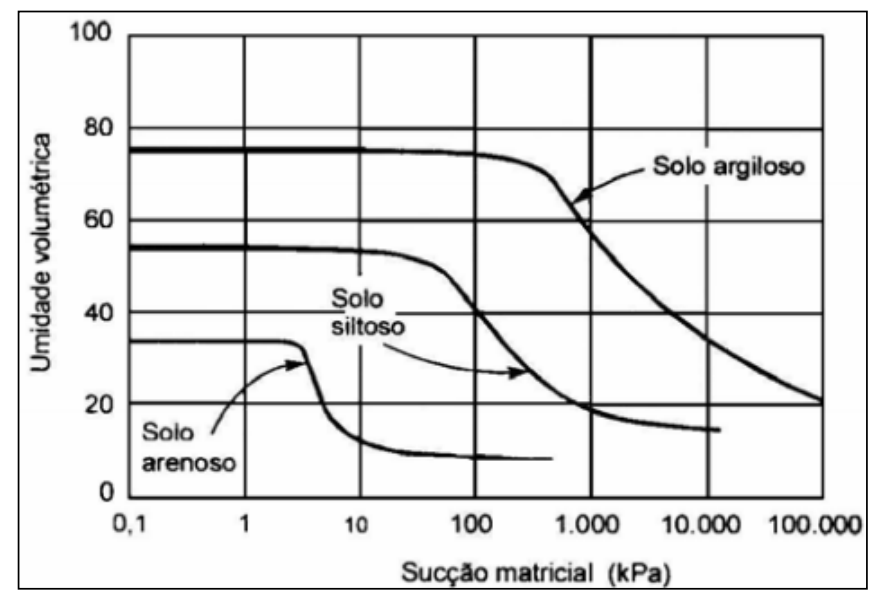

Figura 2.6 - Representação das curvas de retenção para os tipos de solos (Vilar, 2000).

Além da diferença das curvas de retenção existentes para os tipos de solos, pode-se verificar uma variabilidade nas curvas em amostras de solos retiradas na mesma profundidade. Este fato pode ser evidenciado no trabalho de Miguel et al. (2006), que apresenta curvas de 
retenção para amostras de solo argilo-siltosa do campo experimental da Universidade Estadual de Londrina no Paraná. As curvas foram determinadas em amostras indeformadas, utilizando a câmara de Richards. O formato das curvas apresentou variabilidade para as amostras coletadas na mesma profundidade. Isso pode ser explicado pelo fato de que, apesar dessas amostras terem sido retiradas do mesmo bloco de solo indeformado, elas apresentaram diferenciações na sua estrutura, o que foi constatado nos valores de teor de umidade e índice de vazios.

Camapum de Carvalho e Leroueil (2004) explicam três tipos de curvas de retenção trabalhadas em termos de pF, que é o logaritmo da sucção em centímetro de coluna d’água versus o grau de saturação. A curva I da Figura 2.7 ilustra o caso mais comum de curva característica de sucção, onde apresenta uma distribuição dos poros bem graduada. A curva é representada com o trecho da pressão de entrada de ar e certa redução do índice de vazios imposta pelo aumento de sucção. A curva II apresenta de forma genérica a forma de curva característica de sucção para solos nos quais a distribuição de poros é mal graduada ou de graduação aberta. Nesta curva é possível verificar o comportamento dos macroporos e microporos, onde o trecho correspondente entre o término de entrada de ar dos macroporos e a entrada de ar dos microporos tem sua forma influenciada pela diferença entre os tamanhos dos mesmos, pela distribuição dos poros compreendidos entre os macro e microporos, pela retração dos elementos agregados nos quais se encontram os microporos e pela própria natureza químico-mineralógica do solo. A curva III representa o caso dos materiais que apresentam fluência com o aumento da sucção, como por exemplo, os solos estabilizados com betume. $\mathrm{O}$ aumento da sucção a partir do ponto de entrada de ar provoca fluência da película de betume que recobre os minerais gerando um efeito de retração no solo e consequentemente a perda de linearização da curva. O contato entre os minerais permite o fim da retração e curva assume forma linear até se aproximar o grau de saturação residual. 


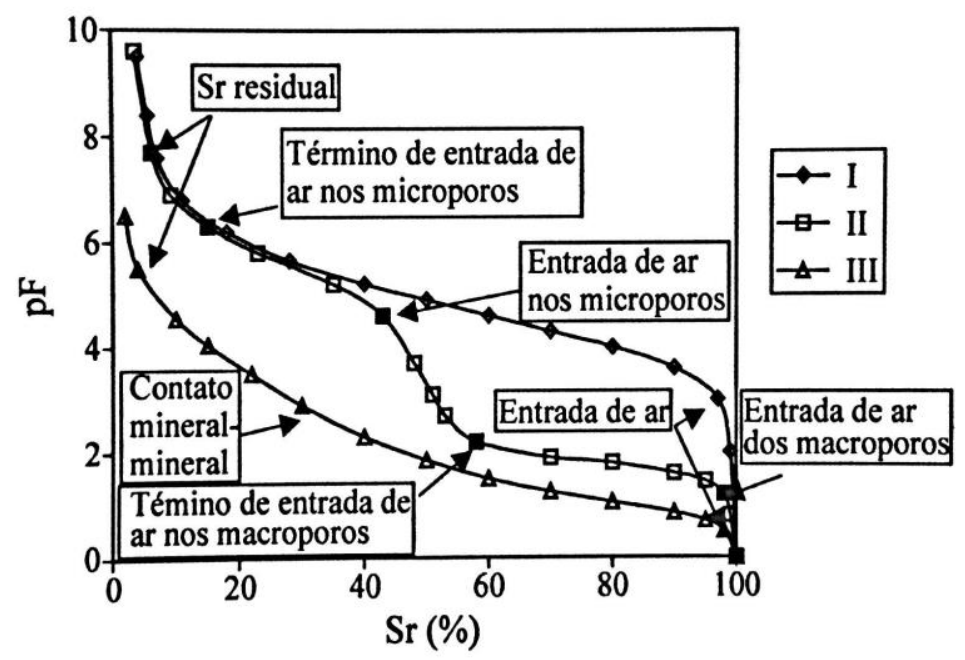

Figura 2.7 - Tipos de curvas características de retenção de água do solo (Camapum de Carvalho e Leroueil, 2004).

Embora outros fatores, tais como, a orientação das partículas e a variação iônica no solo também possam modificar a forma da curva, nota-se que é importante analisar a distribuição dos poros e do índice de vazios na definição das curvas características de retenção de água do solo.

Marshall (1958) apresentou uma relação direta entre a sucção matricial e a distribuição de poros do solo, na qual pode ser relacionada com a forma das curvas características de sucção apresentadas na Equação (2.4).

$$
D=\frac{4 T}{\left(u_{a}-u_{w}\right)}
$$

Onde D é o menor diâmetro dos poros não saturados, T é a tensão superficial da água (75 kPa $\mu \mathrm{m})$ e $\left(u_{a}-u_{w}\right)$ é a sucção matricial.

De acordo com Likos e Lu (2007), a relação dos dois extremos sucção versus teor de umidade, muitas vezes referida como curva característica de sucção, ou curva característica de umidade do solo é um dos parâmetros mais importantes que regem o comportamento mecânico e hidrológico de solos não saturados. Alguns autores exemplificam que as características de sucção mátrica são utilizadas, geralmente, para modelar e prever o coeficiente de permeabilidade em fluxo de água subterrânea para solos não saturados. Enquanto que as características de sucção total têm sido aplicadas na avaliação quantitativa e qualitativa do potencial expansivo de solos argilosos (McKeen, 1992; Johnson, 1978). 


\subsubsection{Histerese}

A curva de retenção pode ser determinada a partir de trajetórias obtidas por procedimentos de umedecimento e secagem das amostras de solo. O processo de secagem consiste em saturar a amostra e impor sucções matriciais crescentes provocando a redução de umidade do solo. No umedecimento a amostra é seca e em seguida submetida a potenciais matriciais decrescentes proporcionando o aumento na umidade do solo. As curvas de retenção obtidas a partir dos dois processos apresentam diferenças na umidade (Figura 2.5), que configura diferentes curvas (Georgetti, 2010).

A histerese dos solos é caracterizada pela diferença entre as trajetórias das curvas obtidas pelo processo de umedecimento e pelo processo de secagem, ou seja, o trecho não coincidente entre o caminho de secagem e o caminho de umedecimento.

De acordo com Hillel (1980), este comportamento afeta de forma direta as condições de fluxo no solo não saturado, e isto pode ser atribuído a diferentes causas, as quais estão relacionadas ao efeito de ângulo de contato do menisco de água; irregularidade na geometria dos poros; presença de bolhas de ar nos vazios; alteração na estrutura do solo.

\subsubsection{Modelos de Ajustes para Curva de Retenção}

$\mathrm{Na}$ literatura existem diversas relações empíricas que ajustam os dados experimentais de sucção e umidade ou grau de saturação. Essas relações são utilizadas para estimar a curva de retenção.

Os modelos de ajuste das curvas de retenção que buscam modelar os dados experimentais por meio de equações matemáticas são divididos em modelos empíricos e modelos de domínio. Os modelos empíricos baseiam-se no ajuste de alguns parâmetros da curva de retenção. Os modelos de domínio assumem os dois estados extremos de umidade do solo: seco e solo saturado.

A Tabela 2.4 apresenta as equações de ajuste mais empregadas para estimar a curva de retenção de água, as quais são de Brooks e Corey (1964), Van Genuchten (1980) e a de Fredlund e Xing (1994). 
Tabela 2.4 - Relações empíricas para estimativa da curva de retenção de água no solo.

\begin{tabular}{|c|c|c|}
\hline Autores & Modelos & Parâmetros \\
\hline Brooks \& Corey (1964) & $\begin{array}{c}\theta=\left(\theta_{s}-\theta_{r}\right) \cdot\left(\frac{\varphi_{a}}{\varphi}\right)^{\tau}+\theta_{r} \rightarrow \operatorname{se} \varphi>\varphi_{a} \\
\theta=\theta_{s} \rightarrow \operatorname{se} \varphi<\varphi_{a}\end{array}$ & $\begin{array}{l}\varphi_{a}-\text { pressäo de entrada de ar [cm] } \\
\theta_{Y} \in \theta_{s} \text { - umidade residual e de saturação } \\
\tau \text { - parâmetro de ajuste }\end{array}$ \\
\hline Van Genuchten (1980) & $\theta=\theta_{Y}+\frac{\left(\theta_{s}-\theta_{Y}\right)}{\left(1+|\alpha \varphi|^{n}\right)^{m}}$ & $\begin{array}{l}\alpha[1 / \mathrm{cm}] \text { - parâmetro de ajuste } \\
\mathrm{n} \text { - parâmetro de ajuste } \\
\mathrm{m}=1-(1 / \mathrm{n}) \\
\theta_{\mathrm{r} e} \theta_{S} \text { - umidade residual e de saturação }\end{array}$ \\
\hline Fredlund \& Xing (1994) & $\theta=\theta_{s}\left[1-\frac{\ln \left(1+\frac{\varphi}{\varphi_{r}}\right)}{\ln \left(1+\frac{10^{6}}{\varphi_{r}}\right)}\right]\left[\frac{1}{\left(\ln \left(e+\frac{\varphi}{a}\right)^{n}\right)}\right]^{m}$ & $\begin{array}{l}\varphi_{r} \text { - sucção correspondente } \\
\mathrm{a} \theta_{r} \\
\text { a - valor aproximado da pressão } \\
\text { de entrada de ar; } \\
\mathrm{n} \text { - parâmetro de ajuste } \\
\mathrm{m}=1-(1 / \mathrm{n}) \\
\theta_{\gamma} \in \theta_{S} \text { - umidade residual e de saturação }\end{array}$ \\
\hline
\end{tabular}

Camapum de Carvalho e Leroueil (2004) comentam que a curva característica de sucção dos solos com distribuição bem graduada dos poros apresenta, normalmente, bom ajuste a estas leis. No entanto, para solos com distribuição de poros mal graduada ou graduação aberta, a curva é considerada como bimodal.

\subsubsection{Tensão Superficial}

Uma molécula no interior da água experimenta forças iguais em todas as direções, o que significa que não há forças desequilibradas. A molécula de água na membrana contrátil sofre uma força desequilibrada para o interior da água. Para que a membrana contrátil entre em equilíbrio, é gerada uma força de tração ao longo da mesma. Devido às suas propriedades, a membrana contrátil exerce uma força de tração a qual é chamada de tensão superficial, $\mathrm{T}_{\mathrm{s}}$ (Fredlund e Rahardjo, 1993).

A tensão superficial faz com que a membrana contrátil se comporte como uma membrana elástica. Se uma membrana flexível bidimensional é sujeita a pressões diferentes de cada lado, esta assume uma curvatura côncava no sentido da maior pressão, e exerce uma tensão na membrana para manter o equilíbrio. A diferença de pressão por meio de uma superfície curva pode ser relacionada com a tensão superficial, e o raio de curvatura da superfície com o equilíbrio através da membrana.

Em solos não saturados, a membrana contrátil pode ser submetida a uma pressão de ar, $\mathrm{u}_{\mathrm{a}}$, que é maior do que a pressão da água, $u_{w}$. A diferença entre essas pressões refere-se à sucção 
matricial, e também, é a causa da curvatura da membrana contrátil. Então, a tensão superficial pode ser determinada pela equação (2.5) (Fredlund e Rahardjo, 1993).

$$
\left(u_{a}-u_{w}\right)=\frac{2 T_{s}}{R_{s}}
$$

Essa equação refere-se ao modelo capilar de Kelvin. Onde $\left(u_{a}-u_{w}\right)$ corresponde à sucção matricial, ou a diferença entre a pressão de ar e de água nos poros na membrana contrátil. A curvatura da membrana contrátil é conhecida como menisco capilar.

A tensão superficial é medida como a força de tração por unidade de comprimento da membrana contrátil, e é tangente à superfície da mesma com amplitude que diminui à medida que a temperatura aumenta.

\subsubsection{Capilaridade}

A capilaridade é definida por Fredlund e Rahardjo (1993) como um fenômeno associado à componente de sucção matricial. A altura de ascensão da água e o raio de curvatura têm implicações diretas sobre a curva característica de água no solo. Essa relação é diferente para os processos de umedecimento e secagem na curva, e este fato pode ser explicado a partir do modelo capilar.

Um tubo pequeno de vidro é inserido na água em condições atmosféricas. A água sobe no tubo como resultado da tensão superficial na membrana contrátil. Esse comportamento é analisado considerando a tensão superficial que atua na superfície circunferencial do menisco, como mostra a Figura 2.8. A Ts influencia no ângulo $\alpha$ medido em relação à vertical, que é chamado de ângulo de contato, e sua magnitude depende da adesão entre as moléculas da membrana contrátil e do material que compreende o tubo (ou seja, o vidro). 

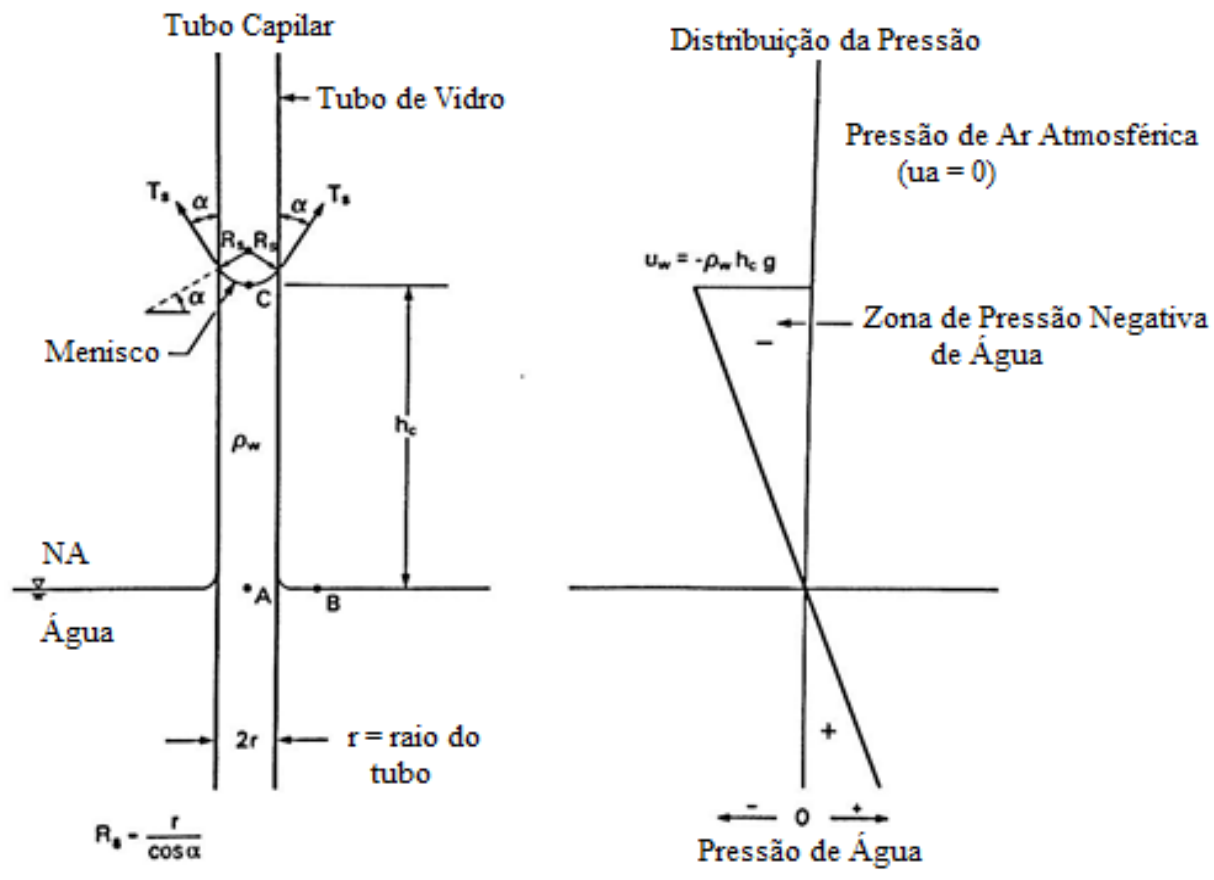

Figura 2.8 - Modelo físico e o fenômeno relacionado à capilaridade (Fredlund e Rahardjo, 1993).

Considerando o equilíbrio de força vertical da água capilar no tubo mostrado na Figura 2.8, a resultante vertical da tensão superficial influencia no peso da coluna de água, que tem uma altura $\mathrm{h}_{\mathrm{c}}$. $\mathrm{O}$ ângulo de contato entre a membrana contrátil para a água pura e o vidro limpo é zero $(\alpha=0)$. Quando o ângulo $\alpha$ é zero, o raio de curvatura, Rs, é igual ao raio do tubo, r. Portanto, a altura de capilaridade da água pura em um tubo de vidro pode ser determinada pela equação:

$$
h_{c}=\frac{2 T_{s}}{\rho_{w} g r}
$$

Onde $r$ é o raio do tubo capilar, $T_{s}$ é a tensão superficial da água, $\alpha$ é o ângulo de contato, $h_{c}$ é a altura capilar, $g$ é a aceleração gravitacional e $\rho_{w}$ é a massa específica da água. O raio do tubo é análogo ao do raio dos poros em solos. A equação mostra que quanto menor o raio de poros no solo, maior será a altura capilar. A altura do capilar pode ser representada graficamente contra o raio do poro usando a equação onde o ângulo de contato é considerado zero.

Hillel (1971) comenta que se o solo fosse constituído por um conjunto de tubos capilares, a relação entre o potencial e os raios dos poros dos solos que formam os meniscos da água poderia ser descrita pela equação da capilaridade. Porém, além do fenômeno de capilaridade, 
as partículas sólidas do solo apresentam a adsorção, que envolve por hidratação as partículas minerais. A Figura 2.9 mostra a interação solo-água.

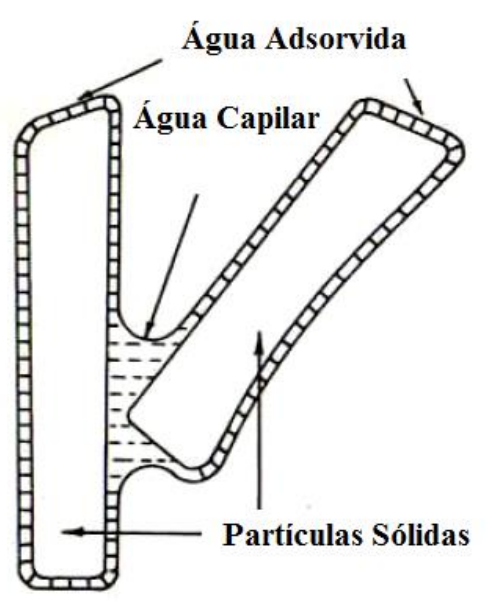

Figura 2.9 - Fenômenos de capilaridade e adsorção associados originando sucção matricial em solos não saturados (Hillel, 1971).

\subsubsection{Estados de Tensões em Solos Não Saturados}

Terzaghi (1936) define o comportamento tensão versus deformação de solos saturados através de uma variável de estado de tensão, conhecida como tensão efetiva, que é determinada por meio das tensões totais e poro pressão, isto é:

$$
\sigma^{`}=\sigma-u_{w}
$$

Em que $\sigma$ é a tensão normal total e $u_{w}$ é a pressão de água nos poros do solo. Porém, o principio das tensões efetivas para solos saturados não pode ser aplicado para solos não saturados. Dessa forma, alguns autores tentaram ampliar o conceito de tensão efetiva por meio de diferentes equacionamentos a fim de aplicar para meios porosos não saturados. Algumas propostas estão mostradas na Tabela 2.5. 
Tabela 2.5 - Equações propostas para tensões efetivas em solos não saturados (Adaptado de Georgetti, 2010).

\begin{tabular}{|c|c|c|}
\hline Autores & Equações & Parâmetros \\
\hline Bishop (1959) & $\sigma^{\prime}=\left(\sigma-u_{a}\right)+x\left(u_{a}-u_{w}\right)$ & $\begin{array}{l}x \text { - parâmetro relacionado com } \\
\text { o grau de saturação e o tipo de solo } \\
u_{a}-\text { pressão no ar }\end{array}$ \\
\hline Lambe (1960) & $\sigma^{\prime}=\left(\sigma \cdot a_{m}\right)+\left(u_{a} \cdot a_{a}\right)+\left(u_{w} \cdot a_{w}\right)+R+A$ & $\begin{array}{l}a_{a} \text { - parte da área total ocupada por ar } \\
a_{m} \text { - área de contato ocupada pelos sólidos } \\
a_{w} \text { - parte da área total ocupada pela água } \\
R \text { - resultante das forças de repulsão } \\
A \text { - resultante das forças de atração }\end{array}$ \\
\hline Richards (1966) & $\sigma^{\prime}=\sigma+x_{m} \cdot P_{m}^{\prime \prime}+x_{s} \cdot P_{s}^{\prime \prime}$ & $\begin{array}{l}P{ }_{m} \text { - sucção matricial } \\
P_{s}{ }_{s}-\text { sucção do soluto } \\
x_{m} \text { e } x_{s}-\text { parâmetros que variam de } 0 \text { a } 1 \\
\text { dependendo da trajetória de tensões. }\end{array}$ \\
\hline
\end{tabular}

Em todas as equações é possível verificar a inclusão de algum parâmetro do solo para tentar estabelecer uma variável única de tensão efetiva, embora, a determinação desses parâmetros seja de difícil obtenção. Por este fato, Colemam (1959) tentaram definir variáveis mensuráveis a partir de estudos realizados com a mecânica do contínuo. Essas variáveis são consideradas independentes, e quando constantes, não alteram o volume do elemento de solo.

\subsection{Métodos de Determinação da Sucção}

A perda ou ganho de umidade é um fenômeno que ocorre de maneira diferente de solo para solo. A caracterização por meio da sucção tornou-se a melhor maneira de se entender o equilíbrio de umidade dos materiais (Marinho, 1994).

Existem várias técnicas utilizadas para medir a sucção no solo sem o auxílio de sobrecarga e em determinadas condições de umidade, índices de vazios e estruturas (Pereira, 2004). Todas as técnicas utilizadas para medida de sucção requerem uma troca de água entre o solo e o sistema de medição.

A curva de retenção pode ser obtida através de métodos diretos ou indiretos. Os métodos diretos resultam nas medidas de sucção sem o auxílio de correlações. Os métodos indiretos permitem obter a sucção do solo pela relação das suas propriedades com as de outros materiais. 
Vilar (2006) apresenta diversos tipos de técnicas, com as faixas de sucção, com os respectivos tipos e faixas de sucção, métodos, vantagens e limitações (Tabela 2.6).

Tabela 2.6 - Métodos para medida de sucção (Vilar, 2002).

\begin{tabular}{|c|c|c|c|c|}
\hline Métodos & Sucção & $\begin{array}{l}\text { Intervalo de } \\
\text { Sucção (kPa) }\end{array}$ & Tempo & Observações \\
\hline Funil de Placa Porosa & Matricial & $0-70$ & horas & $\begin{array}{l}\text { Sucção é aplicada diretamente à amostra. } \\
\text { Bom para baixas sucções onde a precisão das panelas é limitada. }\end{array}$ \\
\hline Câmara de Richards & Matricial & $0-1.500$ & horas & $\begin{array}{l}\text { Emprega a técnica da translaçao de eixos } \\
\text { Depende da capacidade da pedra porosa (pressão de entrada de ar) } \\
\text { Continuidade da fase ar. }\end{array}$ \\
\hline Membrana de Pressão & Matricial / Total & até 10.000 & dias & $\begin{array}{l}\text { Emprega a técnica da translaçao de eixos } \\
\text { Emprega membrana de celulose. }\end{array}$ \\
\hline Tensiômetro & Matricial & $0-70$ & Minutos & $\begin{array}{l}\text { Tempo de resposta: depende da condutância da pedra porosa; } \\
\text { Sensibilidade do elemento de medida; } \\
\text { Existem tensiômetros baseados em princípios osmóticos; } \\
\text { Tensiômetro de alta capacidade (pressões de } 1 \mathrm{~atm} \text { ) }\end{array}$ \\
\hline Papel Filtro & $\begin{array}{l}\text { Matricial (papel - } \\
\text { solo em contato) } \\
\text { Total (papel - solo } \\
\text { sem contato) }\end{array}$ & $\begin{array}{l}30-30.000 \\
400-30.000\end{array}$ & 7 dias & $\begin{array}{l}\text { Depende do contato entre o solo; } \\
\text { Necessita de calibração do papel; } \\
\text { Evitar a formação de fungos; } \\
\text { Pesagem: precisão } 0,0001 \mathrm{~g}\end{array}$ \\
\hline Blocos Porosos & Matricial & $10-1.000$ & Semanas & $\begin{array}{l}\text { Baseia-se na condutividade elétrica dos materiais porosos (gesso, fibra } \\
\text { de vidro, etc); } \\
\text { Resistência elétrica (ohms x sucção) } \\
\text { Desvantagens: solubilidade do gesso, histerese, sensível a altas sucções. }\end{array}$ \\
\hline Psicrômetros & Total / Osmótica & $100-8.000$ & Minutos & $\begin{array}{l}\text { Depende de controle de temperatura rigoroso, principalmente em baixas } \\
\text { sucções; } \\
\text { Mais recomendado para laboratório; } \\
\text { Sucção osmótica: mede sucção de extrato da solução do solo } \\
\text { (confiabilidade precária); }\end{array}$ \\
\hline $\begin{array}{l}\text { Sensores de } \\
\text { Condutividade Térmica }\end{array}$ & Osmótica & todos os valores & Minutos & $\begin{array}{l}\text { Condutividade elétrica do extrato da solução; } \\
\text { Concentração do soluto; } \\
\text { Extrato + psicrômetros: resultados precisos. }\end{array}$ \\
\hline Equilibrio de Vapor & Total & $\begin{array}{l}\text { todas as faixas } \\
\text { acima de } 400\end{array}$ & Dias & $\begin{array}{l}\text { Solução com concentração conhecida, umidade relativa, sucção total; } \\
\text { Amostra de solo em dessecador sem contato com a solução até o } \\
\text { equilibrio de peso; } \\
\text { Equilibrio demorado. }\end{array}$ \\
\hline Princípios Osmóticos & Matricial & 200 a 1.600 & Horas & $\begin{array}{l}\text { Solo em contato com solução com concentração conhecida (umidade } \\
\text { relativa conhecida) através de membrana seletiva; } \\
\text { Solução de PoliEtilenoGlicol (PEG), peso molecular 20.000; } \\
\text { Útil para instalar e controlar sucção em ensaios. }\end{array}$ \\
\hline
\end{tabular}




\subsubsection{Técnica da Translação de Eixos}

A técnica da translação de eixos foi proposta por Hilf (1956), e baseia-se no princípio das placas de pressão. A aplicação dessa técnica envolve o controle da pressão de ar e o controle ou a medida da pressão de água, e a drenagem ou sorção de água pelo corpo de prova. Conhecidos esses valores, tem-se a sucção no solo, que consiste na diferença $\left(\mathrm{u}_{\mathrm{a}}-\mathrm{u}_{\mathrm{w}}\right)$.

Esta técnica consiste em mudar o referencial de pressão (atmosférica), a qual configura a translação de eixos. Para que isto seja possível, a pressão de ar é aumentada, o que leva a um aumento igual da pressão de água, permanecendo a diferença $u_{a}-u_{w}$, ou seja, permanece a sucção. Dessa forma, a pressão de água é aumentada, partindo de valores baixos e impossíveis de medir, até valores mensuráveis pelos equipamentos convencionais (Vilar, 1997).

Dessa forma, em ensaios com sucção controlada tem-se a possibilidade de conhecer duas variáveis de estado de tensões, a tensão total líquida $\left(\sigma-\boldsymbol{u}_{w}\right)$ e a sucção (Vilar, 2002). O autor ressalta, ainda, caso exista ar ocluso na água do solo, os valores obtidos podem estar alterados, com uma sobre medida da sucção. Assim, deve-se cogitar, para graus de saturação altos (ou baixas sucções), a possibilidade de valores incorretos de sucção, a partir do uso desta técnica.

Em ensaios de laboratório, a técnica só apresenta sucesso se houver o controle ou medida da poropressão de água e de ar. Essa medida pode ser realizada através de uma pedra porosa saturada com alto valor de pressão de entrada de ar.

O ensaio consiste em aplicar diferentes níveis de sucção por meio da injeção de pressão de ar em um corpo de prova alocado em contato direto a uma pedra porosa. Tanto a amostra, como a pedra porosa, encontram-se saturadas ao iniciar o ensaio. A câmara é semelhante a um edômetro convencional. São registradas variações de umidade a cada estágio de sucção pela medida de volume de água que é expulsa por uma bureta graduada (Soto, 2004).

\subsubsection{Câmara de Pressão (Câmara de Richards)}

As curvas de retenção de água construídas por meio da técnica da placa porosa, ou panela de pressão foram obtidas a partir da metodologia proposta por Richards (1965), determinando pares de umidade do solo correspondente a um dado potencial matricial aplicado.

O autor descreve em sua metodologia que a extração de água ocorre por diferença de potencial entre a placa porosa e a amostra de solo e, o fluxo de água é exponencialmente 
reduzido quando o potencial matricial tende a ser negativo, especialmente quando se aproxima de $-1500 \mathrm{kPa}$, o que despende tempo muito grande para atingir o equilíbrio da umidade na amostra.

Como mostra a Figura 2.10, o equipamento consiste em uma câmara de pressão hermeticamente fechada, composta de uma placa porosa interna com vazios muito pequenos que permite, dentro de certos limites, o fluxo de água, porém, não de ar. Essas placas são conhecidas como placas de alta pressão de entrada de ar, sendo o elemento chave para o controle da sucção neste equipamento e em praticamente todas as técnicas experimentais que empregam o princípio da translação de eixos (Silva, 2005).

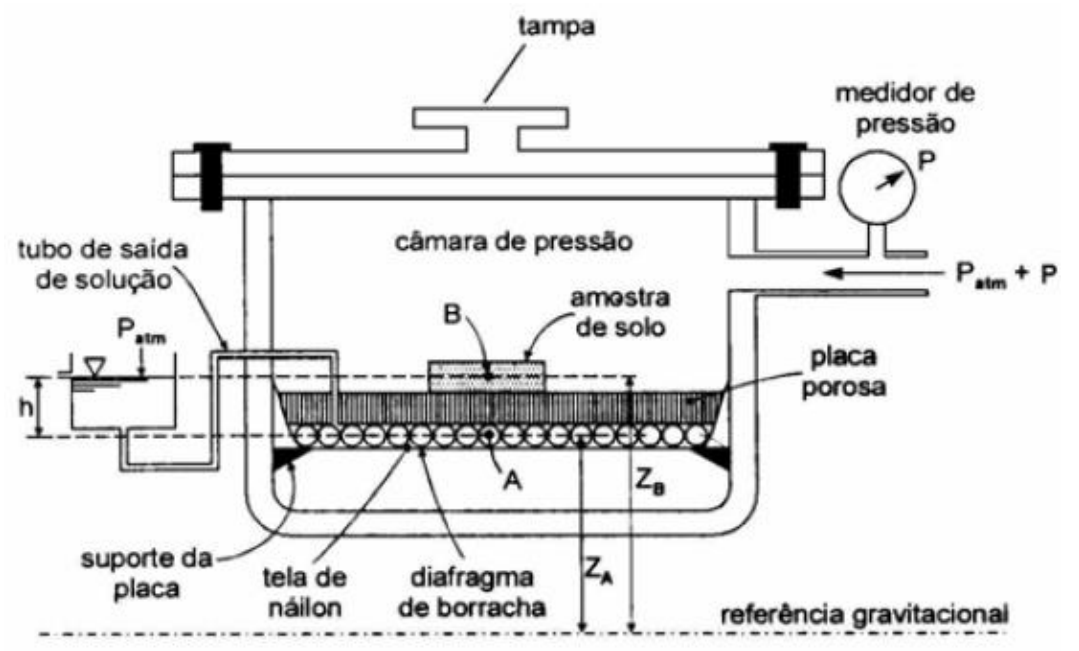

Figura 2.10 - Câmara de pressão de Richards (Libardi, 1995, modificado de Pereira, 2004).

Vilar (2006) comenta que o limite de trabalho é dado pelo valor da pressão que é capaz de dar início ao fluxo de ar através da placa. A Figura 2.11 apresenta o equipamento e a disposição das amostras no interior da câmara de pressão de Richards. 


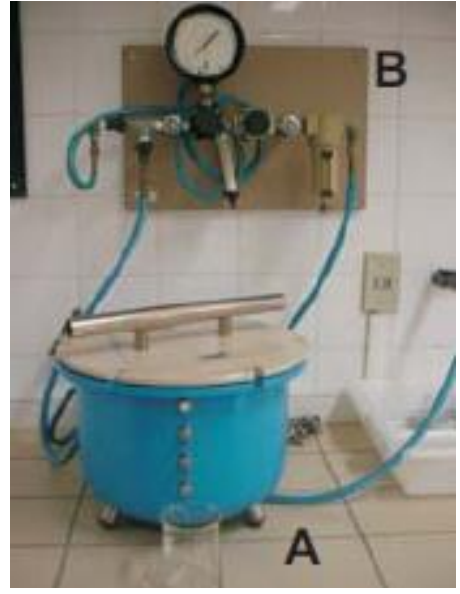

(a)

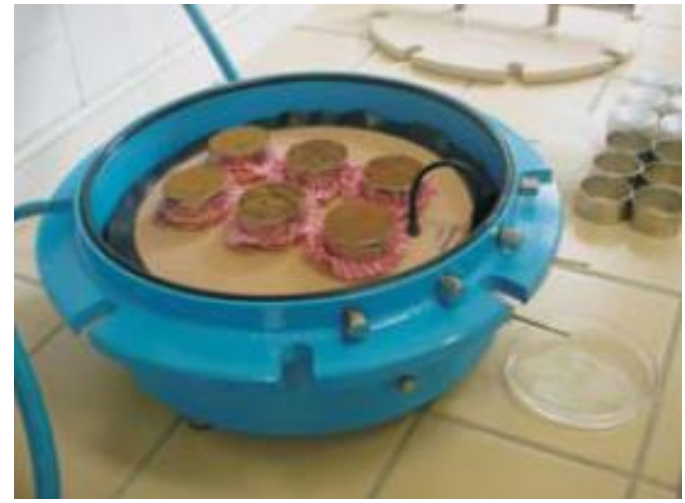

(b)

Figura 2.11 - (a) Câmara de pressão de Richards (A - câmara de baixa pressão; B - painel para controle da pressão); (b) Amostras sobre a membrana conectada ao dreno da câmara de pressão (Fonte: EMBRAPA, 2007).

Georgetti et al. (2007) avaliou o desempenho de uma técnica alternativa para a determinação da curva de retenção de água no solo com o propósito de ser uma rápida determinação em relação às técnicas convencionais, como o de placa de pressão. A técnica consiste em utilizar uma câmara de pressão permitindo a instalação da sucção através da técnica da translação de eixo e a medida da pressão na água intersticial do solo. A Figura 2.12 apresenta a câmara alternativa que permite determinar a sucção pela diferença de pressão entre a pressão de ar inicial e a da água, e também as umidades de equilíbrio com as sucções aplicadas. Dessa forma, constrói-se a curva de retenção do solo ensaiado. Os autores realizaram ensaios com quatro solos e a câmara alternativa conduziu a resultados semelhantes aos fornecidos por outras técnicas, como a da placa de pressão convencional e o papel filtro.

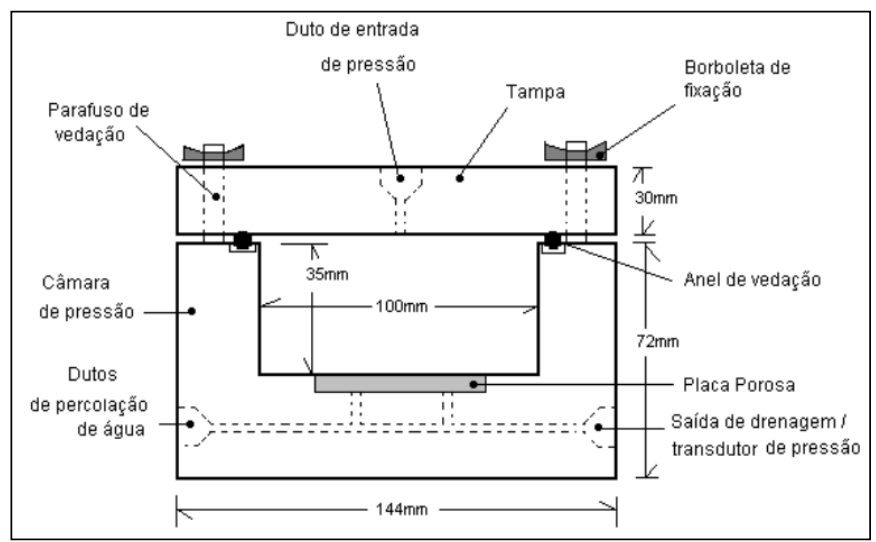

Figura 2.12 - Câmara de pressão alternativa (Georgetti et al., 2007). 


\subsubsection{Método do Papel Filtro}

O método do papel filtro parte do princípio de que um solo ao entrar em contato com um material poroso com capacidade de absorver água, a mesma irá passar do solo para esse material poroso até que o equilíbrio seja alcançado. A partir da relação entre sucção e umidade do material poroso (calibração), a sucção do solo pode ser obtida referindo-se à curva de calibração. O estado de equilíbrio fornece a mesma sucção do solo e também no material poroso, porém com umidades diferentes. O tempo de equilíbrio é um fator importante para a obtenção de valores corretos de sucção (Marinho, 1994).

De acordo com Fredlund e Rahardjo (1993), o método do papel filtro permite obter medidas de sucção matricial e sucção total. Quando o fluxo capilar, ocorrido entre as partículas de solo e as fibras do papel, interage com a água nos poros mede-se a sucção matricial. E quando as moléculas de água têm que escapar da água dos poros vencendo as forças capilares no solo e eventual força osmótica, ocorre o fluxo de vapor. Neste caso, a medida obtida é a sucção total.

Para a medida da sucção matricial o papel filtro é colocado em contato com a amostra e isolado do ambiente externo em saco plástico e colocado na câmara úmida por sete dias até atingir equilíbrio entre o fluxo de água do solo para o papel. Após este período determina-se a umidade do papel filtro, e a sucção é conhecida através da curva de calibração do papel filtro.

Vários aspectos devem ser levados em consideração na realização deste ensaio, visto que, esta técnica não possui uma padronização aceita mundialmente. Isso implica na existência de variações e adaptações realizadas constantemente pelos pesquisadores. Um dos fatores de maior relevância para a medida correta da sucção é o tempo de equilíbrio. Marinho (1994) sugere tempos de equilíbrio para medida da sucção total, ou seja, sem contato com a amostra (Tabela 2.7). O papel filtro utilizado para este ensaio é o Whatman $\mathrm{N}^{\circ} 42$.

Tabela 2.7 - Tempo de equilíbrio sugerido para medida de sucção total, em função do nível de sucção (Marinho, 1994).

\begin{tabular}{cc}
\hline Sucção Total (kPa) & Tempo de Equilíbrio Sugerido \\
\hline $0-100$ & $>30$ dias \\
$100-250$ & 30 dias \\
$250-1.000$ & 15 dias \\
$1.000-30.000$ & 7 dias \\
\hline
\end{tabular}


Marinho (1994) comenta que um dos aspectos mais importantes para se obter uma acurácia nas medidas de sucção é garantir que o papel filtro, após o equilíbrio, seja removido do ambiente de equilíbrio sem perda significativa de umidade.

\subsubsection{Técnica Osmótica}

A técnica osmótica para o controle de sucção não é uma prática comum em ensaios geotécnicos de solos saturados. Esta técnica permite a drenagem da amostra por meio do processo de osmose, no qual a mesma é colocada sobre uma membrana de celulose semiimpermeável que é permeável somente à água; e abaixo da membrana circula uma solução de polietileno de glicol (PEG). De acordo com Pereira (2004), essa solução é caracterizada por uma baixa reação química e alta solubilidade com água, sendo o tamanho das moléculas considerado o aspecto mais importante.

As moléculas de PEG de tamanho grande não penetram na membrana, o que resulta em uma sucção osmótica aplicada à amostra por meio da membrana. As membranas de PEG podem ser de vários tamanhos, sendo definido pelo seu peso molecular que pode variar entre $6.000 \mathrm{~g}$ (PEG 6.000) e 20.000g (PEG 20.000).

A primeira adaptação desta técnica para ser aplicada em estudos de solos expansivos com ensaios edométricos foi proposta por Kassif e Ben Shalom (1971). Delage et al. (1992) realizaram melhorias no oedêmetro envolvendo a utilização de um circuito fechado e uma bomba de circulação da solução para o controle da troca do volume de água com mais precisão.

A adaptação da técnica osmótica para a determinação das propriedades de retenção de água dos solos é mostrada na Figura 2.13 (Cui e Delage, 1996). Amostras cilíndricas (tipo triaxial, com $38 \mathrm{~mm}$ de diâmetro) foram cuidadosamente inseridas em uma membrana em forma de tubo previamente umedecidas. A membrana e a amostra são imersas em solução de PEG agitada, cuja concentração corresponde ao valor de sucção desejado. A variação do peso da amostra é monitorizada em função do tempo. A sucção atingiu o equilíbrio no período de uma semana. 


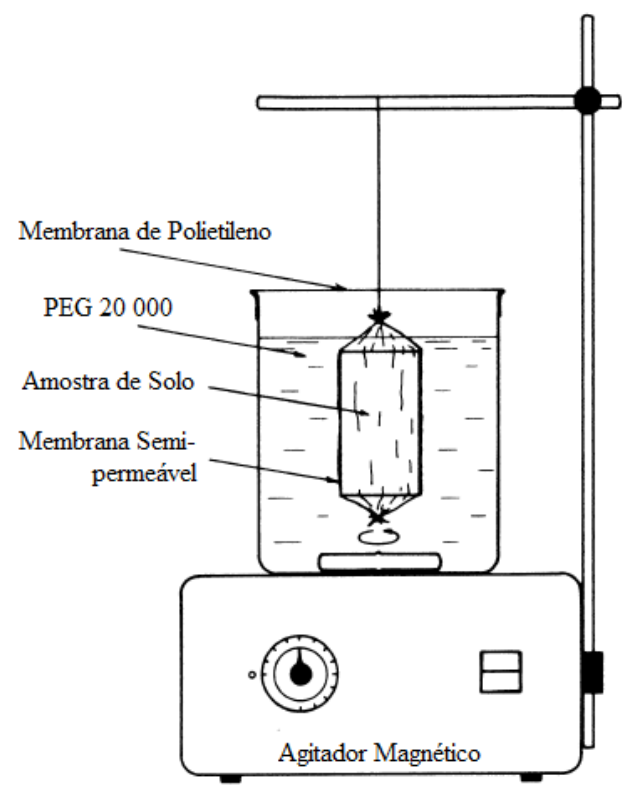

Figura 2.13 - Técnica osmótica utilizada para determinação das propriedades de retenção de água (Cui e Delage, 1996).

No sistema osmótico o valor de sucção depende da concentração da solução; quanto maior for a concentração, maior será a sucção. A relação entre a pressão osmótica e a concentração de solução de PEG é conhecida por dois pesos moleculares (PEG 6.000 e 20.000), uma vez que os resultados consistentes foram obtidos por diferentes autores, como demonstrado por Williams e Shaykewich (1969). Os autores comentam que valores de sucção para a relação pressão osmótica versus concentração da solução são limitados até um valor máximo de 1.500 kPa. Soto (2004) comenta que Delage et al. (1998) estenderam essa faixa de pressão osmótica para um valor de $10.000 \mathrm{kPa}$.

Soto (2004) comenta, também, que na prática a aplicação da sucção desejada dependerá da variação da concentração durante o ensaio, pois ocorrerá uma transferência de umidade entre o solo e a solução através da membrana.

\subsubsection{Tensiômetro}

Esta técnica é uma alternativa empregada para determinar a curva de retenção em campo. O equipamento é constituído de um tubo fechado preenchido com água deaerada. Neste tubo é acoplada uma pedra porosa cerâmica que permite a permeabilidade de água e sais. O sistema composto pelo tubo e a cápsula cerâmica é ligada a um manômetro (ou vacuômetro) que fornece as pressões atuantes na profundidade onde a pedra porosa é instalada (Figura 2.14). 


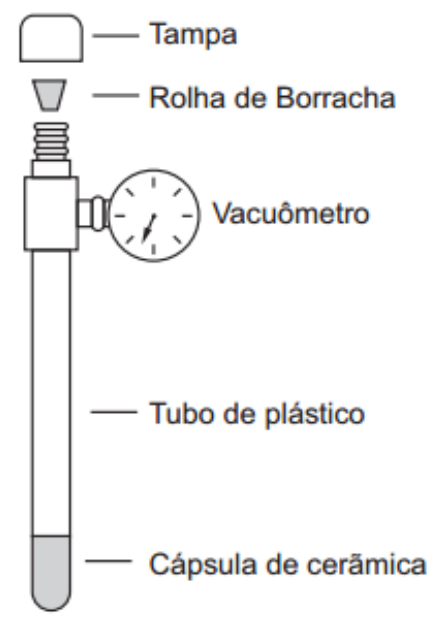

Figura 2.14 - Desenho esquemático do tensiômetro (Fonte: INSA, 2013).

A medida da pressão é obtida por meio da pressão atuante na fase líquida do solo, que é transmitida ao reservatório de água do sistema, ou seja, a partir de condições de equilíbrio de pressões (sucção) entre o solo não saturado e o tensiômetro.

A pressão atuante na fase líquida do solo não saturado é negativa, portanto, o limite da medição da sucção matricial pelo tensiômetro é a pressão de cavitação. O surgimento dessa pressão propicia o aparecimento de bolhas de ar e descontinuidades, limitando as pressões neste equipamento para até $70 \mathrm{kPa}$ (Pereira, 2004).

O uso dos tensiômetros permite medida indireta de umidade, visto que, a sucção matricial é correlacionada à umidade por meio da curva de retenção de água (Fagundes, 2010).

Para obtenção de valores de sucção superiores a 100 kPa sem cavitação no sistema, utiliza-se o tensiômetro de alta capacidade proposto por Ridley e Burland (1995).

\subsubsection{Técnica de Controle da Sucção por Imposição de Umidade Relativa}

A técnica do controle de sucção por imposição de umidade relativa é uma alternativa utilizada para medir a sucção total do solo. É conhecida, também, como técnica do equilíbrio de vapor - VET (vapour equilibrium technique), e pode ser aplicada em diferentes temperaturas.

Esta técnica permite a determinação da sucção total de forma indireta, relacionando este fenômeno com algumas propriedades, dentre elas, a temperatura, a umidade relativa, umidade do material, entre outras. 
De acordo com Fredlund e Rahardjo (1993), a sucção do solo refere-se ao estado de energia livre da água do solo. Essa energia livre pode ser medida através da pressão parcial de vapor. A relação termodinâmica entre a sucção do solo (ou da energia livre da água do solo) e a pressão parcial de vapor da água nos poros do solo pode ser descrita pela expressão:

$$
\varphi=-\frac{R \cdot T}{M \cdot g} \ln \left(\frac{P}{\bar{P}_{0}}\right)
$$

Onde,

$\varphi=$ sucção do solo ou sucção total $(\mathrm{kPa})$

$\mathrm{R}=$ constante universal do gás (molar) $[8,31432 \mathrm{~J} /(\mathrm{mol} \mathrm{K})]$

$\mathrm{T}=$ temperatura absoluta $\left[\mathrm{T}=\left(273,16+\mathrm{t}^{\circ}\right)(\mathrm{K})\right]$

$\mathrm{t}^{\circ}=$ temperatura

$M=$ massa molecular do vapor de água $[18,016 \mathrm{~kg} / \mathrm{kmol}]$

$g=$ aceleração gravitacional $\left[9,81\left(\mathrm{~m} \cdot \mathrm{s}^{-1}\right)\right]$

$P=$ pressão parcial de vapor da água nos poros $(\mathrm{kPa})$

$P_{0}=$ pressão de saturação de vapor de água sobre uma superfície plana de água pura à mesma temperatura $(\mathrm{kPa})$.

A equação anterior mostra que o estado de referência para a quantificação dos componentes de sucção é a pressão do vapor acima de uma superfície plana de água pura (sendo esta água sem sais ou impurezas). O termo $P / P_{0}$ é conhecido como umidade relativa, RH (\%). Se for fixada uma temperatura de referência equivalente a $20^{\circ} \mathrm{C}$, as constantes da Equação (2.9) resultam em $135022 \mathrm{kPa}$. Então, esta equação pode ser escrita:

$$
\varphi=-135022 \ln \left(P / P_{0}\right)
$$

Os autores apresentaram um gráfico que mostra a relação entre a umidade relativa e a sucção total para três diferentes temperaturas. A Figura 2.15 mostra esse gráfico no qual indica que a sucção total, $\varphi$, é igual a 0 (zero) quando a umidade relativa, RH, é igual a 100\%. Os valores de umidade relativa menores que $100 \%$ indicam que há presença de sucção no solo. A Figura 2.15 mostra também que as sucções podem apresentar valores extremamente elevados, como por exemplo, uma umidade relativa de $94,24 \%$ na temperatura de $20^{\circ} \mathrm{C}$ corresponde a sucção de $8000 \mathrm{kPa}$. 


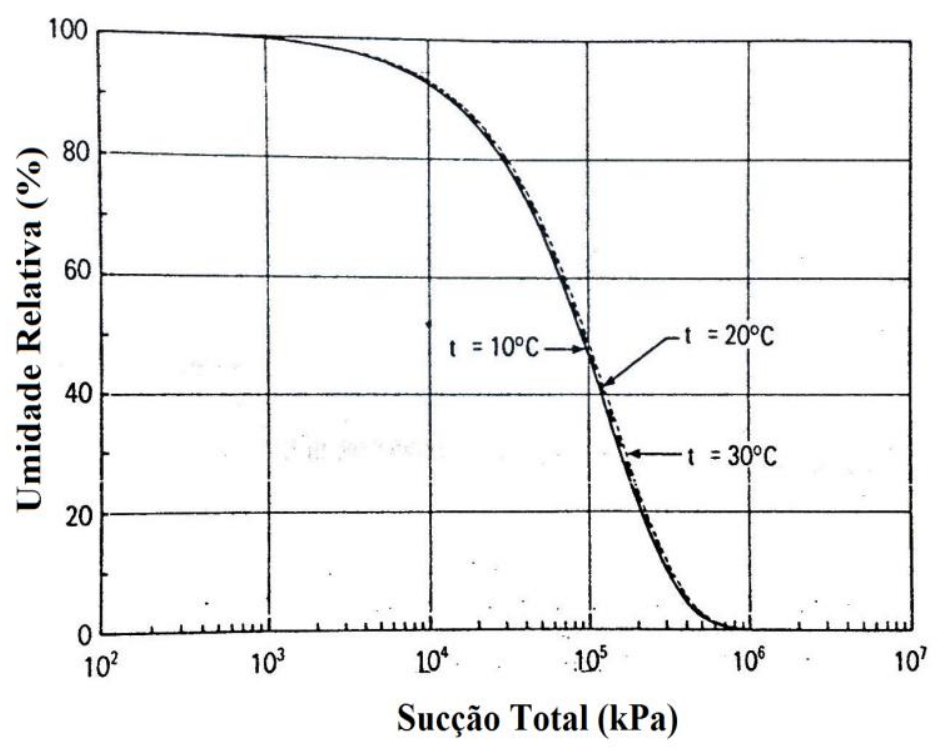

Figura 2.15 - Umidade relativa versus sucção total (adaptado de Fredlund e Rahardjo, 1993). Entre os métodos de controle de umidade relativa em laboratório estão incluídos os métodos isopiésticos (pressão constante de aquecimento do gás), métodos a vácuo e o método da dupla pressão. Para o controle isopiésticos da umidade, são aplicadas soluções saturadas e não saturadas de sal e ácido que permitem atingir o equilíbrio termodinâmico em pequenos reservatórios fechados. Em condições isotermais, a umidade relativa, imposta por uma solução, alcança um valor fixo e irreversível que depende da concentração da solução (Likos e $\mathrm{Lu}, 2007)$.

Lang (1967) realizou uma série de calibrações de soluções salinas com uma solução de cloreto de sódio $(\mathrm{NaCl})$ para determinar o coeficiente osmótico. As diferentes concentrações dos sais perimitiram impor sucções entre 4.000 e $25.000 \mathrm{kPa}$. O coeficiente osmótico da solução de $\mathrm{NaCl}$ é representado pela expressão:

$$
\Phi=\frac{1.000 \cdot \ln \left(\frac{P}{P_{0}}\right)}{v \cdot m \cdot M \cdot g}
$$

Neste caso, $\Phi$ é o coeficiente osmótico, $v$ é o número de íons de uma molécula de sal $(v=2$ para $\mathrm{NaCl}$ ), m é o número de moles de soluto para 1.000 de solvente.

Ao relacionar a equação (2.9) com a equação (2.10) é possível obter duas expressões que relacionam o potencial de água com o coeficiente osmótico para o $\mathrm{NaCl}$ (Lang, 1967): 


$$
\begin{array}{ll}
\Phi_{m}=-2 . R \cdot T \cdot m \cdot \Phi & {[\mathrm{J} / \mathrm{kg}]} \\
\left(u_{a}-u_{w}\right)=0,002039 \cdot R \cdot T \cdot m \cdot \Phi & {[\mathrm{MPa}]}
\end{array}
$$

Onde $\Phi_{m}$ é o potencial matricial. No entanto, o coeficiente osmótico pode ser obtido a partir da expressão:

$$
\begin{gathered}
\Phi=1-\frac{S_{f} \sqrt{\mathrm{do}}}{\mathrm{A}^{3} \cdot m}\left[(1+\mathrm{A} \sqrt{m})-2 \ln (1+\mathrm{A} \sqrt{m})-\frac{1}{(1+\mathrm{A} \sqrt{m})}\right]+\mathrm{Bm}+\mathrm{Cm}^{2}+\mathrm{Dm}^{3} \\
\text { do }=1-\frac{(\mathrm{t}-3,9863)^{2}(\mathrm{t}+288,9414)}{508929,2(\mathrm{t}+68,12963)}
\end{gathered}
$$

Em que,

A, B, C, D = parâmetros de ajuste;

do = densidade do solvente;

$\mathrm{t}=$ temperatura em ${ }^{\circ} \mathrm{C}$.

Os valores de $\mathrm{S}_{\mathrm{f}} \sqrt{\mathrm{do}}, \mathrm{A}, \mathrm{B}, \mathrm{C}$ e $\mathrm{D}$ são apresentados pelo autor em um grupo de valores calculados a partir de Hardner e Owen (1958) para um intervalo de temperatura entre 0 e $40^{\circ} \mathrm{C}$. A Tabela 2.8 apresenta esses valores que permitem calcular a sucção total substituindo nas equações anteriores.

Tabela 2.8 - Valores de $S_{\mathrm{f}} \sqrt{\mathrm{do}}, \mathrm{A}, \mathrm{B}, \mathrm{C}$ e D apresentados por Lang (1967).

\begin{tabular}{cccccc}
\hline $\mathbf{t}^{\circ} \mathbf{C}$ & $\mathbf{S f} / \mathbf{d o}$ & $\mathbf{A}$ & $\mathbf{B}$ & $\mathbf{C}$ & $\mathbf{D}$ \\
\hline 0 & 1,1225 & 1,3339 & 0,725 & 10,69 & $-0,38$ \\
5 & 1,1336 & 1,3621 & 1,115 & 11,25 & $-0,61$ \\
10 & 1,1422 & 1,3811 & 1,580 & 9,85 & $-0,40$ \\
15 & 1,1512 & 1,3910 & 1,892 & 10,16 & $-0,53$ \\
20 & 1,1607 & 1,3923 & 2,293 & 9,70 & $-0,56$ \\
25 & 1,1705 & 1,3924 & 2,655 & 9,60 & $-0,69$ \\
30 & 1,1806 & 1,3847 & 3,187 & 7,68 & $-0,48$ \\
35 & 1,1910 & 1,3785 & 3,673 & 5,48 & $-0,18$ \\
40 & 1,2016 & 1,3645 & 4,176 & 3,66 & 0,02 \\
\hline
\end{tabular}

A sensibilidade da umidade relativa às variações de temperatura não depende somente da temperatura absoluta $\mathrm{T}$ mostrada na equação (da umidade relativa). Essa sensibilidade depende, também, da propriedade física do componente químico. Delage et al. (1998) 
realizaram a calibração de diversas soluções salinas para várias temperaturas, como apresentado na Figura 2.16.

Os autores selecionaram alguns sais com diferentes concentrações em um intervalo de sucções baixas $(4-24 \mathrm{MPa})$ com uma solução de cloreto de sódio pura $(\mathrm{NaCl})$ à varias concentrações. Foi utilizada a curva de calibração proposta por Lang (1967). Essas soluções saturadas foram colocadas em contato com o vapor de soluções a diferentes concentrações de $\mathrm{NaCl}$ até se atingir o equilíbrio.

Os resultados mostraram que a solução de $\mathrm{NaCl}$ apresentou a menor variação de umidade relativa para vários valores de temperatura. Os autores comentam que este aspecto é importante na escolha do tipo de sal, o qual confirma a necessidade de um bom controle de temperatura durante o controle da sucção por transferência de vapor.

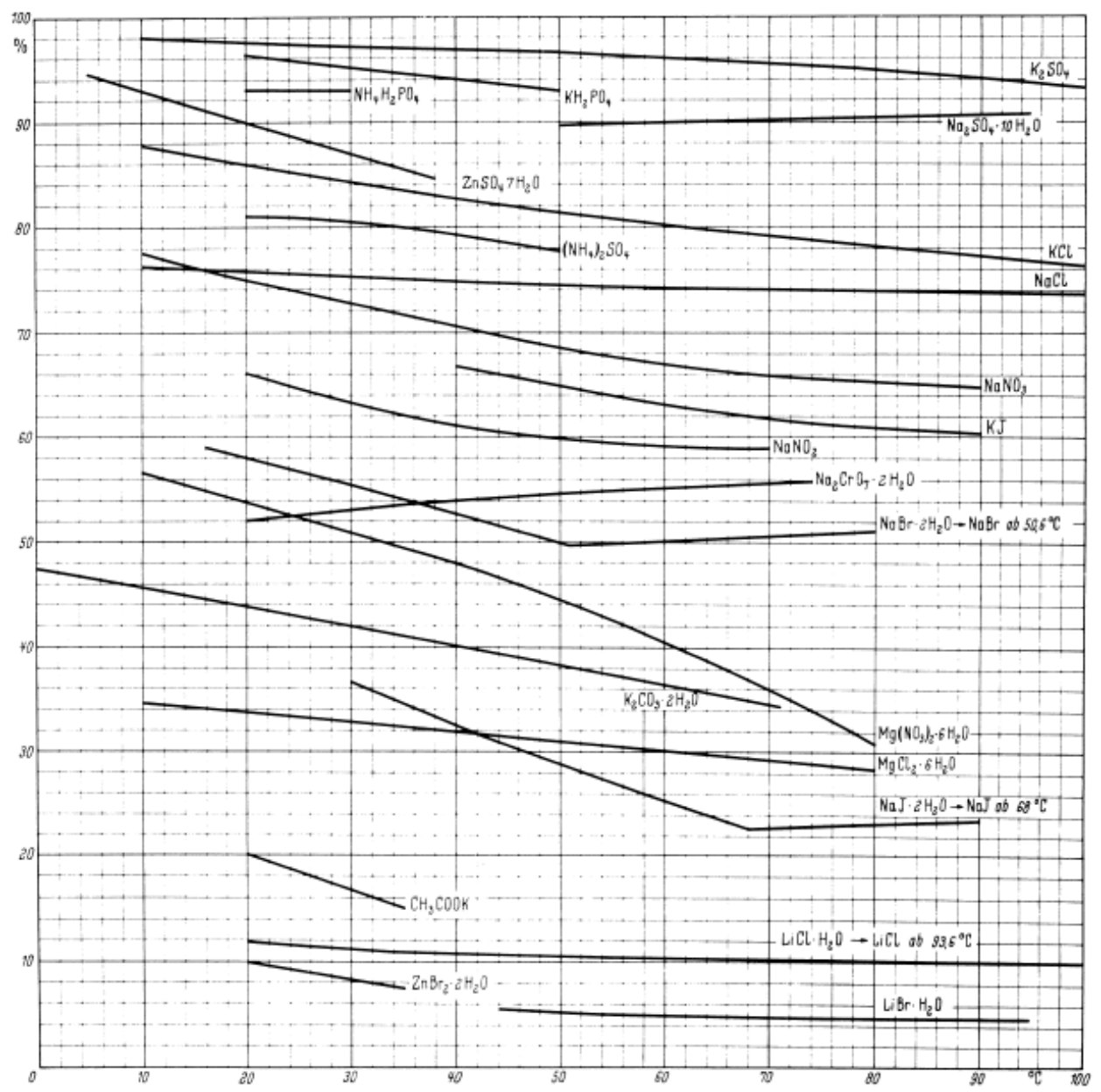

Figura 2.16 - Sensibilidade de soluções salinas quanto à temperatura (Delage et al., 1998). 


\section{a) Determinação em laboratório}

Em laboratório, as amostras são colocadas em um dessecador de vidro a vácuo sob uma placa porosa que fica alocada sob um reservatório com soluções químicas. Trocas de água entre as fases líquida e de vapor são atingidas, o que implica na umidade relativa imposta dentro do dessecador. A pressão parcial de vapor resultante devido ao ambiente está diretamente relacionada com a concentração da solução (Blatz et al., 2008).

Os autores comentam que as soluções químicas utilizadas para impor as condições de sucção são de dois tipos, sendo soluções saturadas de sal e soluções ácidas não saturadas. As soluções salinas saturadas são vantajosas por não apresentarem variação na concentração devido à troca de água em forma de vapor. A limitação está no intervalo de sucção a ser trabalhada, que depende do tipo específico de sal, devido às propriedades e pureza do componente químico. A vantagem da utilização de soluções ácidas não saturadas é que podem ser impostas sucções mais elevadas, e o controle torna-se mais fácil pela concentração da solução.

A aplicação dos dois tipos de soluções químicas demonstra longo tempo para atingir condições de equilíbrio. Este fato pode ser explicado devido ao processo de difusão que controla a transferência de água em vapor entre a amostra e o reservatório no dessecador.

\section{b) Trabalhos realizados com o uso da transferência de vapor}

Delage et al. (1998), Saiouri et al. (2000), Loiseau (2001) e Monte-H et al. (2003) utilizaram a técnica da transferência de vapor com imposição de umidade relativa através de soluções salinas. A vantagem de utilizar uma solução salina saturada é que a fração molar da água em uma solução não varia com a troca de umidade entre a fase líquida e a fase gasosa. A sucção imposta, que está relacionada com a fração molar da água é, portanto, mantida constante. Contudo, a limitação desse método na aplicação prática é a descontinuidade nos valores obtidos de sucção (Tang e Cui, 2005).

Autores como Belanteur et al. (1997), Villar (1999), Cuisiner e Masrouri (2002) e Lloret et al. (2003) utilizaram este método de circulação de umidade e conseguiram o equilíbrio em menos de três semanas. Blatz e Graham (2000) também permitiram a circulação de umidade diretamente no entorno da amostra diminuindo o comprimento de drenagem, e concluíram que esse processo promoveu a aceleração do ganho de umidade da amostra. 
Segundo Tang e Cui (2005), o tempo para que o teor de umidade da amostra entre em equilíbrio é de aproximadamente um a dois meses. Para reduzir o tempo de ensaio, Marcial et al. (2002) desenvolveu um método no qual é utilizado uma bomba pneumática para circular a umidade do ar gerada em um frasco contendo a solução salina para dentro da câmara onde está localizada a amostra. Os testes foram realizados de duas maneiras, sendo a primeira com as amostras colocadas em um dessecador totalmente fechado contendo uma dada solução salina na parte inferior. No segundo procedimento adotou-se a bomba para circulação da umidade. Os resultados mostraram que o segundo método permitiu a redução no tempo de equilíbrio da umidade em duas a quatro semanas.

O uso de soluções não saturadas é vantajoso, pois permitem uma série contínua de valores de sucção, porém, apresentam certa dificuldade prática em manter a concentração constante durante o ensaio.

A transferência de vapor pode ser aplicada, também, em altas temperaturas. Romero (1999) e Villar (2000) utilizaram ácido sulfúrico em várias concentrações para o controle de sucção. A umidade relativa foi calculada como uma função da molalidade da solução por meio de uma função empírica.

Vale ressaltar, que os problemas decorrentes da aplicação do fluxo forçado em sistemas fechados está associado à pressão de ar e diferentes temperaturas geradas ao longo do circuito. Em outras palavras, isso significa que a umidade relativa a qual se pretende aplicar pelo reservatório de referência não pode ser atribuída ao sistema restante e ao longo da altura da amostra de solo, visto que, há uma diminuição da pressão do ar em locais específicos no circuito (Dueck, 2004).

Likus e Lu (2007) desenvolveram um sistema computadorizado automático para controlar a sucção total durante o ensaio da curva de retenção de água do solo por umedecimento e secagem através da circulação de gás de nitrogênio em uma câmara fechada. $O$ sistema permite impor sucções totais da ordem entre 620.000 e $14.000 \mathrm{kPa}$. O equilíbrio do teor de umidade foi determinado por meio de uma balança integrada ao sistema a qual permitiu controlar as pesagens da amostra. $\mathrm{O}$ ensaio não necessitou de interrupção, e em cerca de uma a duas semanas determinou-se a curva de retenção de água. Os autores concluíram que o teor de umidade imposto na câmara é continuamente medido através da água absorvida ou não 
absorvida em resposta à sucção aplicada. Portanto, neste caso, o tempo de equilíbrio depende apenas da capacidade de absorção e do tipo de solo.

Outra constatação importante no ensaio com fluxo de ar úmido forçado é o comportamento da amostra sob condições de carregamento. Em uma amostra de solo submetida a tensões verticais baixas e sucções elevadas, a porosidade é alta e o grau de saturação é baixo, o que permite um fluxo de ar úmido dentro da amostra. Contudo, se a amostra estiver com densidade seca elevada devida tensões verticais, ou simplesmente pelo elevado grau de saturação, o fluxo de ar tende a desaparecer e a variação de sucção no solo torna-se difícil de alcançar. Assim, é possível que o fluxo de ar ocorra somente entre as pedras porosas nas extremidades (Pintado et al., 2009).

\subsection{Identificação de Solos Expansivos}

A identificação de solos expansivos é uma etapa essencial para o sucesso dos projetos de engenharia, devidos aos danos causados pela instabilidade nas construções. É possível detectar o potencial de um solo quanto à expansibilidade in situ por exame tátil-visual das características do material, ou por meio de ensaios em laboratório. Esta fase permite caracterizar o solo de forma preliminar qualitativa, a fim de nortear os engenheiros dos possíveis problemas que possam ocorrer na implantação da obra, alertando, assim, a necessidade de ensaios adicionais.

Schreiner (1987) propõe metodologias de identificação e classificação divididas em diretas e indiretas como apresentado na Tabela 2.9. Os métodos indiretos são aqueles relacionados à identificação mineralógica, índices físicos, limites de consistência ou parâmetros ligados à textura, composição e comportamento do solo. Os métodos diretos são baseados na medida de expansão induzida ao solo, ou da tensão necessária para impedir esta expansão, por meio de ensaios edométricos.

Outras técnicas utilizadas na medição das variações volumétricas, entre elas: a expansão livre (Holtz e Gibbs, 1956) e as mudanças de potencial de volume (Lambe, 1960). Estas técnicas avaliam a pressão de expansão unidimensional, considerando apenas a deformação axial. 
Tabela 2.9 - Métodos indiretos e diretos de identificação de solos expansivos (Ferreira, 1995 modificado de Schreiner, 1987).

\begin{tabular}{|c|c|c|c|}
\hline Métodos & Sub-divisões & Crité rio & Referências \\
\hline \multirow{9}{*}{ Indiretos } & \multirow[t]{2}{*}{ Identificativos } & $\begin{array}{l}\text { Difração de raio X; } \\
\text { Microscopia eletrônica de varredura; } \\
\text { Análise termo-diferencial; } \\
\text { Adsorção de etileno-glicol e glicerina }\end{array}$ & Ayala et al. (1986) \\
\hline & & Físico-químicos & Fink et al. (1971) \\
\hline & \multirow{4}{*}{ Qualitativos } & Granulometria & Prinklonski (1952), Skempton (1953) \\
\hline & & Índices de Consistência & Seed et al. (1962); Van der Merwe (1964) \\
\hline & & Índices Físicos & Chen (1965), Vijayverviya e Ghazzaly (1973) \\
\hline & & Classificação Geotécnica & Rodriguez Ortiz (1975), Cuellar (1978) \\
\hline & \multirow{3}{*}{ Orientativos } & Geologia & Patrick e Snethen (1976) \\
\hline & & Geomorfologia & Ayala et al. (1986) \\
\hline & & Pedologia e Identificação Visual & Ferreira $(1990$ e 1993$)$ \\
\hline \multirow{5}{*}{ Diretos } & Avaliativos & Ensaio de Expansão de Lambe & Lambe (1960) \\
\hline & \multirow{4}{*}{ Quantitativos } & Expansão livre e Tensão de expansão & Seed et al (1962), Chen (1965) \\
\hline & & Ensaios edométricos duplos e & Vijayverviya e Ghazzaly (1973) Rodriguez Ortiz (1975) \\
\hline & & simples & Cuellar (1978) e Jimenez Salas (1980) \\
\hline & & Ensaios edométricos de sucção controlada & $\begin{array}{c}\text { Escario (1967 e 1969), Aitchinson et al. (1973) } \\
\text { Jhonson (1978), Mc Keen (1980) }\end{array}$ \\
\hline
\end{tabular}

Dentre as técnicas indiretas, pode-se destacar também, a porosimetria por intrusão de mercúrio (PIM), a qual permite analisar a variação de tamanho dos poros do material quando sofrem variação de volume. A porosimetria por intrusão de mercúrio foi sugerida por Washburg (1921) para determinar a distribuição de poros a partir da injeção de mercúrio por pressão em meio poroso.

De acordo com Mata (1998), essa técnica consiste em fechar uma amostra porosa num recipiente, desgaseificá-la, e em seguida, submeter a pressões crescentes de mercúrio. Sendo um líquido não-molhante, o mercúrio penetra nos poros menores à medida que a pressão dada pelo porosímetro aumenta. Para cada valor de pressão mede-se o volume de mercúrio forçado a entrar nos poros das amostras. A autora comenta ainda que o mercúrio não penetra naturalmente em pequenas aberturas e/ou fendas dos sólidos porosos, sendo necessária a aplicação de uma determinada pressão no mercúrio para forçar a sua penetração, de forma a vencer a força intersticial que é determinada pelo diâmetro dos poros.

Kayabali e Demir (2011) comentam que a utilização de diferentes técnicas para determinar a expansão unidimensional pode levar a discrepância de resultados. Como exemplo, Sridharan et al. (1986) mostrou que a pressão de expansão obtida em ensaio a volume constante para uma amostra de solo foi de $380 \mathrm{kPa}$, enquanto que no ensaio de consolidação-expansão (swell-load) para a mesma amostra de solo a pressão de expansão atingiu valor de $1300 \mathrm{kPa}$. Este exemplo simples ilustra as discrepâncias entre as diferentes técnicas que podem revelar 
elevadas diferenças percentual. Outro ponto importante a se destacar são os valores extremos de pressão de expansão, como o de 3400 kPa reportado por Shuai (1996).

A utilização de diversos tipos de edômetro para determinação da pressão de expansão pode apresentar elevado grau de incertezas, o que pode ser imperioso afirmar qual seria o ensaio mais confiável a ser utilizado.

Existem diversas metodologias e classificações para determinar o grau de expansibilidade do solo, sendo a maioria baseada em ensaios de laboratório rotineiros, como a granulometria e índice de plasticidade (Skempton, 1953; Holts e Gibs, 1956; Seed, 1962; Van der Merwe 1964). Existem também os ensaios de indicadores relacionados às propriedades físicoquímicas (Adsorção de Azul de Metileno), ou o uso de técnicas mais elaboradas como a Difração de Raios-X (DRX), Análise Térmica Diferencial (ATD) e Microscopia Eletrônica de Varredura (MEV), compondo assim, várias formas de identificar a expansão. Técnicas de determinação direta do grau de expansibilidade também são empregadas por meio de ensaios de pressão de expansão e expansão livre.

Para medir a pressão de expansão que o material exerce quando a expansão é impedida, são utilizadas várias técnicas a partir de ensaios edométricos, tais como: expansão a volume constante, ensaio edométrico simples e ensaios edométricos. Todas essas técnicas permitem analisar a variação volumétrica do material expansivo e são classificadas como metodologias diretas de identificação e classificação.

Ferreira e Ferreira (2009) destacam os principais métodos para avaliar a pressão de expansão do solo na Figura 2.17 envolvendo diferentes trajetórias de tensão. Os métodos citados são: (1) Carregamento após expansão com diferentes sobrecargas; (2) Expansão e colapso sob tensão; (3) Método a volume constante; (4) Ensaio edométrico duplo; (5) Rao et al. (1988); e (6) Justo et al. (1984). A diferença entre os métodos é basicamente a ordem entre a aplicação de carga e a inundação.

O primeiro método inunda amostra antes do carregamento; o método 2 a amostra é carregada antes da inundação; no método 3 a amostra é carregada e inundada simultaneamente e a deformação é impedida; no método 4, são dois corpos de prova, onde um é carregado na umidade natural e o outro carregado após a inundação; no método 5, ocorre como no método 3 até que a pressão de expansão se torne constante, após esta etapa, aumenta-se o carregamento, a fim de comprimir o solo; e no método 6, a curva de inundação sob 
carregamento é dependente do estado de tensão do solo. Os autores descrevem os ensaios da seguinte forma:

Método 1) O ensaio de Carregamento Após Expansão com diferentes sobrecargas consiste em aplicar uma tensão $\sigma_{o}$ na amostra confinada em um anel, onde a mesma expande por inundação. Mede-se a deformação específica em intervalos de tempo até a estabilização. Em seguida, a amostra é consolidada com o aumento da tensão aplicada até que o corpo de prova volte para a altura inicial. A pressão de expansão da amostra é a máxima obtida no ensaio.

Método 2) O ensaio de Expansão e Colapso Sob Tensão consiste na aplicação de tensão em uma amostra de solo após consolidação. Em seguida, ocorre a inundação com medidas de deformação. Em um papel semilogaritmo é marcada a tensão e deformação. Este procedimento é repetido por mais dois corpos de prova, no mínimo. A partir da reta traçada com esses valores, obtém-se a pressão de expansão por extrapolação, que corresponde à deformação zero.

Método 3) O Método a Volume Constante permite medir a pressão necessária para impedir a variação de volume do solo após inundação.

Método 4) O Ensaio Edométrico Duplo mede a pressão no estado inundado que corresponde ao mesmo índice de vazios inicial do corpo de prova na umidade natural.

Método 5) O método de Rao et al. (1988), dá continuidade no ensaio a volume constante, aplicando pequenos e sucessivos incrementos de tensão no corpo de prova na condição inundada, impedindo a variação de volume. Em seguida, tensões são aplicadas como no ensaio de adensamento convencional. A pressão de expansão é obtida de forma semelhante à determinação da tensão de pré-adensamento de um solo saturado.

Método 6) O método de Justo et al. (1984) determina a pressão de expansão a partir da interseção das curvas de inundação sob tensão e de deformação sob umidade constante. 


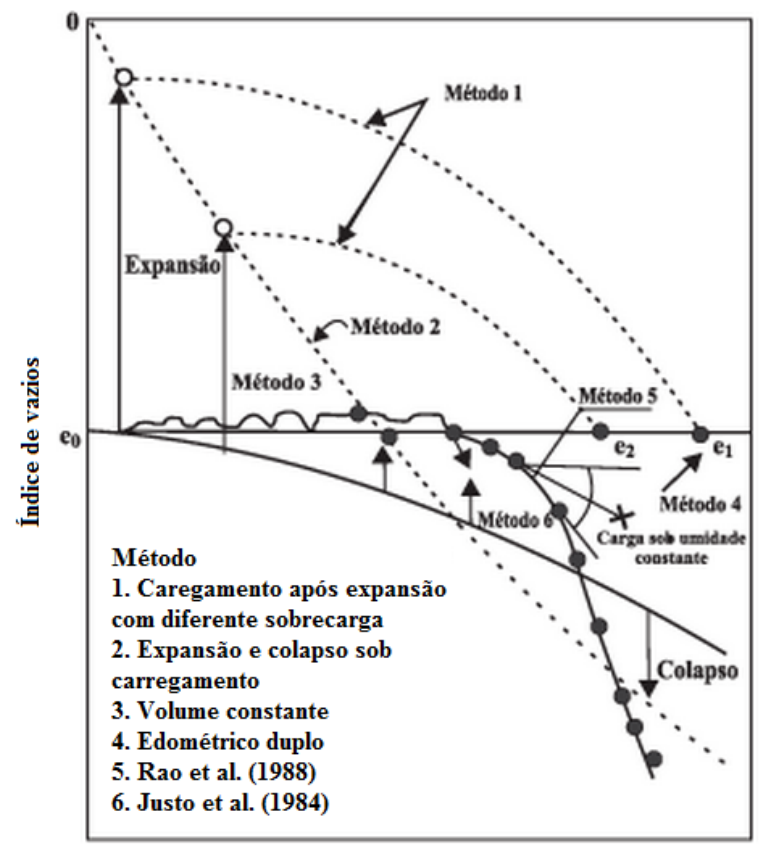

Tensão vertical de consolidação

Figura 2.17 - Metodologias para determinação da pressão de expansão (Ferreira e Ferreira, 2009).

De acordo com Petry et al. (1992), Basma et al. (1995), Shuai (1996), Attom e Barakat (2000) os ensaios mais utilizados são os de expansão livre, expansão à volume constante e o edométrico.

\subsubsection{Expansão Livre}

O ensaio de expansão livre é uma técnica utilizada para determinar a expansão através da medição de variação da espessura da amostra em função do tempo, com relação à sua altura inicial. É um ensaio simples, visto que a amostra é imersa em um recipiente com água e em seguida são realizadas medidas de deformação axial. Este ensaio segue as recomendações da ISRM (1972; 1989), e a expansão é determinada pela expressão:

$$
E=\frac{\Delta H}{H} \times 100
$$

Sendo,

E - expansão livre uniaxial (\%);

$\Delta \mathrm{H}$ - máximo acréscimo de altura;

$\mathrm{H}$ - altura inicial do corpo-de-prova. 
O equipamento para determinação da expansão livre é mostrado na Figura 2.18. Os resultados dos ensaios são plotados em forma de gráfico com valores de deformação (\%) versus tempo.

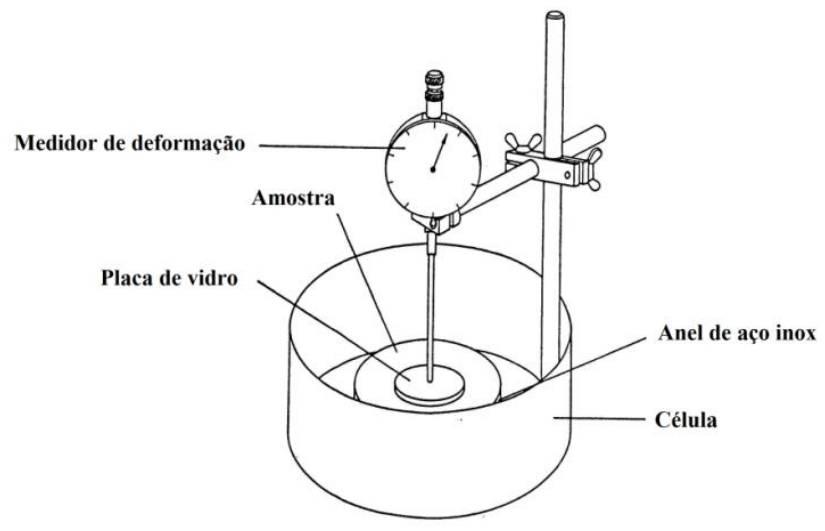

Figura 2.18 - Equipamento para medida de expansão livre (adaptado de ISRM, 1989).

Delgado (1986) analisou a influência da tensão aplicada na expansão "livre", a partir de uma série de ensaios com diferentes valores de tensões aplicadas $(0,15,1,80,7,40$ e 12,00 kPa), em uma argila compactada (Arahal-A) coletada da Barreira La Paz de Arahal (Serilla). O grau de compactação de 100 \%, com variação da umidade ótima de 6,7\%. O autor verificou que, quanto menor a tensão vertical aplicada, maiores os valores da expansão "livre" e a dispersão dos resultados.

Jucá e Lins (1992) comentam que as tensões usualmente aplicadas são de $1 \mathrm{kPa}, 7 \mathrm{kPa}$ e 10 $\mathrm{kPa}$, e que em muitos casos na literatura não é citada a tensão aplicada, como se esta fosse nula no ensaio. A metodologia de Chen (1965) utiliza a tensão de $50 \mathrm{kPa}$ e amostras deformadas (compactadas ou secas ao ar).

\subsubsection{Pressão de Expansão}

Há diferentes métodos para avaliar a pressão de expansão, e podem ser divididos em dois grupos: sem o controle de sucção e com o controle de sucção. Os ensaios sem controle de sucção mais utilizados se restringem ao método da amostra a volume constante e os ensaios edométricos. Os ensaios com controle de sucção contemplam: edométrico com controle de sucção de Escario (1967), baseado na técnica da translação de eixos proposta por Hilf (1956); edométrico com membrana osmótica; edométrico com controle de sucção por imposição de umidade relativa, dentre outros. 
2.5.2.1 Método da amostra a volume constante

O método da amostra a volume constante é realizado em um edômetro convencional conforme os critérios propostos pela ISRM (1989), permitindo a determinação da pressão de expansão (Figura 2.19). Neste método o corpo de prova é submetido a uma tensão vertical pré-estabelecida, sendo inundado em seguida. O ensaio mede a pressão axial necessária para forçar a amostra a manter a altura constante quando confinada e imersa em água.

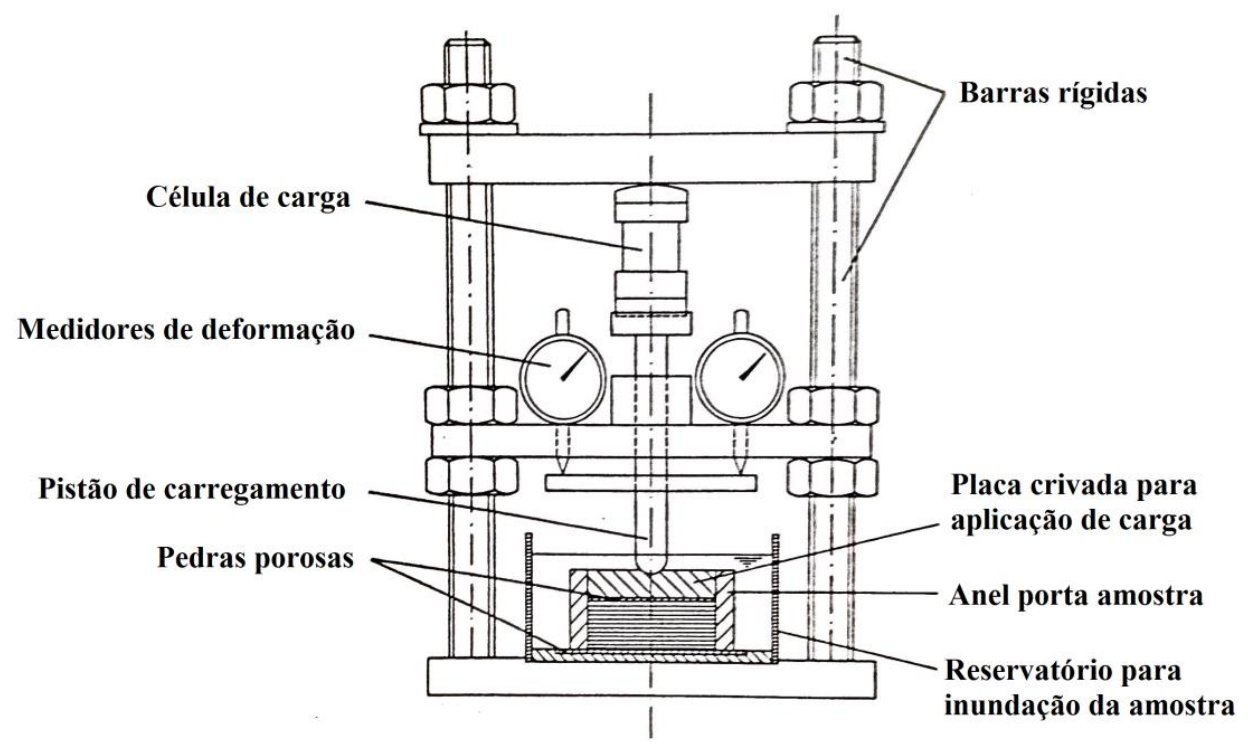

Figura 2.19 - Equipamento para medida de pressão de expansão axial (adaptado da ISRM, 1989).

\subsubsection{Edométrico Direto}

Este ensaio utiliza amostras indeformadas ou deformadas moldadas em um edômetro convencional na condição de umidade natural submetida a um carregamento que corresponde à sobrecarga do terreno. Ao fim da consolidação após os devidos acréscimos de carga aplicada, amostra é inundada permitindo a expansão até que atinja a estabilização. Após a aplicação de todos os incrementos de carga, como em um ensaio de consolidação, obtém-se a curva e versus $\log \sigma$. A partir do gráfico determina-se a $\Delta \mathrm{e}$, que corresponde à variação do índice de vazios, pela consequente variação de volume da amostra (Presa, 1984).

\subsubsection{Edômetro Duplo}

O ensaio edométrico duplo foi idealizado por Jennins e Knight (1957) como uma metodologia simples para o estudo de solos colapsíveis, sendo posteriormente adaptado para a quantificação de solos expansivos. 
Neste ensaio são utilizadas duas amostras, de maneira que seja o mais semelhante possível, as quais sofrem carregamentos sucessivos em dois edômetros distintos. Durante o ensaio uma das amostras se mantem com umidade natural, enquanto que a outra é inundada desde o início do experimento. A amostra ensaiada na umidade natural permite determinar o índice de vazios inicial sob tensão vertical.

Ferreira et al. (2009) avaliaram, por meio de ensaios edométricos simples e duplos com diferentes valores de umidade inicial e tensões externas aplicadas, a variação do volume e a pressão de expansão do solo, devido à mudança do teor de água, em um Vertissolo coletado no município de Petrolândia no estado de Pernambuco. A tensão de expansão foi avaliada por seis métodos distintos. Os resultados concluem que a expansão devido ao acréscimo de umidade é maior para o solo com menor umidade inicial e maior tensão vertical externa aplicada. A ordem com que o solo é solicitado ou inundado influencia o valor da tensão de expansão. Verificou-se também que a tensão de expansão a ser considerada no projeto deve ser aquela que melhor representa a condição de campo. A inundação leva a aumento de volume (expansão) ou diminuição (colapso) em função da umidade inicial e da tensão vertical aplicada ao solo. Conclui-se ainda, que a variação de volume, devido à variação do teor de água, está associada à condição inicial em que se encontra o solo e àquela a que será submetido.

\subsubsection{Edômetro com Sucção Controlada}

O ensaio de pressão de expansão com controle de sucção utiliza uma célula edométrica que possibilita conhecer o comportamento do solo não saturado quanto à variação de volume. Neste caso, o controle de sucção e a aplicação da tensão vertical possibilitam a realização de diferentes trajetórias de tensões de sucção (Futai, 1997).

As células edométricas com controle de sucção foram estudadas por Escario (1967; 1969), Barden et al. (1969), Chang (1969), Atchinson e Woodburn (1969), Escario e Sáez (1973), Fredlund e Morgenstern (1976), entre outros. Alguns autores apresentaram modificações no arranjo do equipamento proposto por Escario (1967; 1969). No Brasil, Ferreira (1995), Machado (1995) e Futai (1997) também desenvolveram células edométricas com controle de sucção para o estudo de solos não saturados.

Escario e Sáez (1973) propuseram uma metodologia a partir de um edômetro com sucção controlada para determinar as características de deformabilidade. $\mathrm{O}$ equipamento é baseado 
no mesmo princípio da câmara de pressão (Figura 2.20), na qual considera-se a água dos poros em contato direto com a água da pedra porosa de alto valor de entrada de ar. O ensaio consiste em confinar a amostra em um anel similar ao do edômetro convencional. A pedra porosa é colocada na base da célula e sobre a mesma a amostra confinada lateralmente. Outra pedra porosa é colocada na parte superior da amostra, e sobre essa pedra é colocado um disco metálico para apoio do pistão de carregamento vertical. Os dispositivos de entrada e saída de água permitem o controle da variação de umidade, e consequente da sucção.

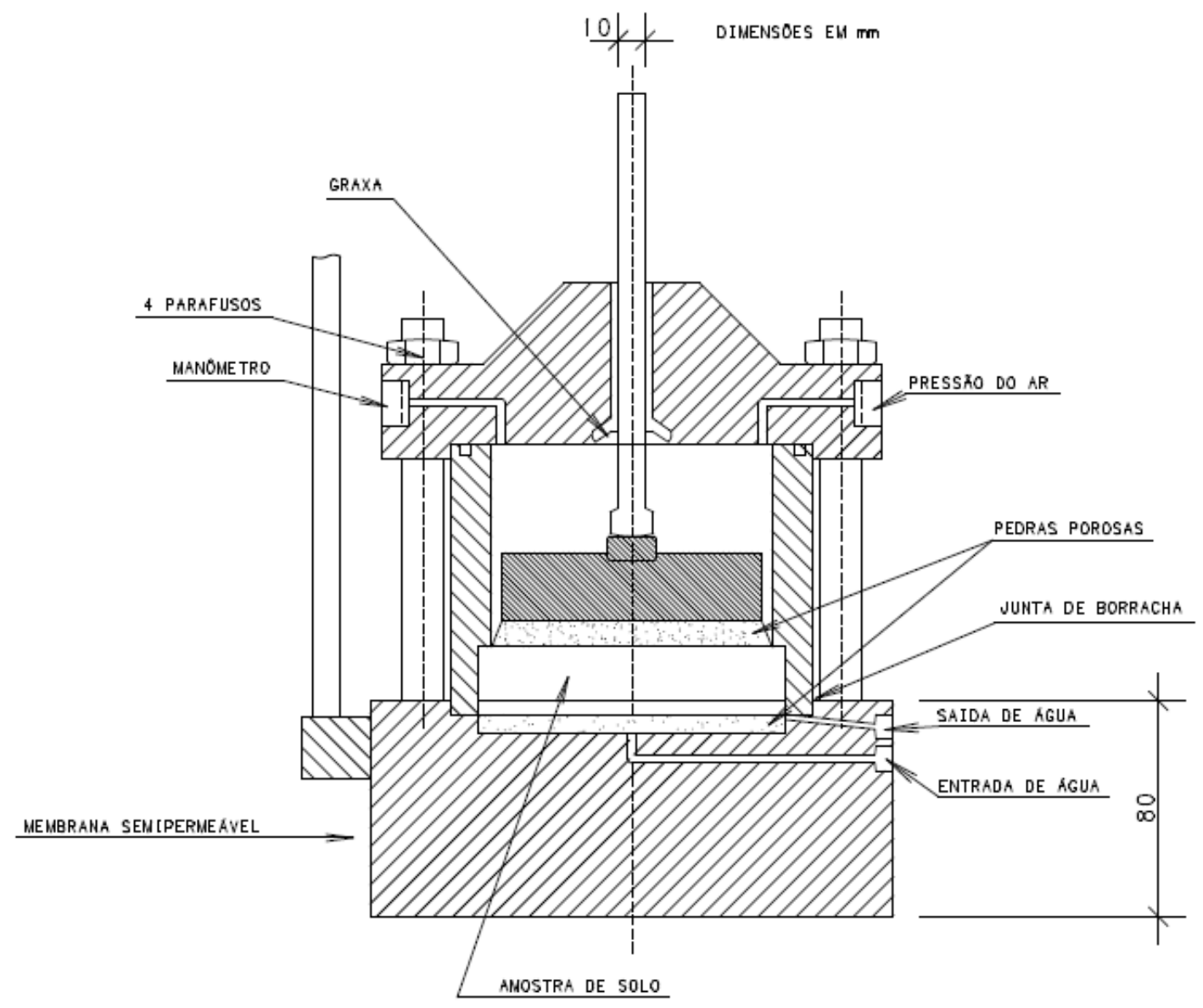

Figura 2.20 - Edômetro com sucção controlada (Escario e Sáez, 1973).

As amostras foram compactadas a 90\% da densidade seca máxima variando-se o teor de umidade. Resultados mostraram que a amostra expande durante o estágio em que a sucção diminui. Entretanto, para a amostra submetida a um valor elevado de tensão de $500 \mathrm{kPa}$, a variação de volume é inversa, ou seja, o solo é comprimido.

Esteban e Sáez (1988) adaptaram a técnica do edômetro para estudar o comportamento deformacional do solo sob condição de sucção elevada. $\mathrm{O}$ equipamento utilizado para o 
ensaio consiste em uma câmara hermética que suporta uma amostra que é confinada por um anel de aço e pedras porosas com tamanhos adequados de poros. $\mathrm{O}$ aparelho possui um depósito destinado às soluções para implementar a umidade relativa, e também um pistão que permite medir a deformação da amostra e aplicação de tensões verticais (Figura 2.21).

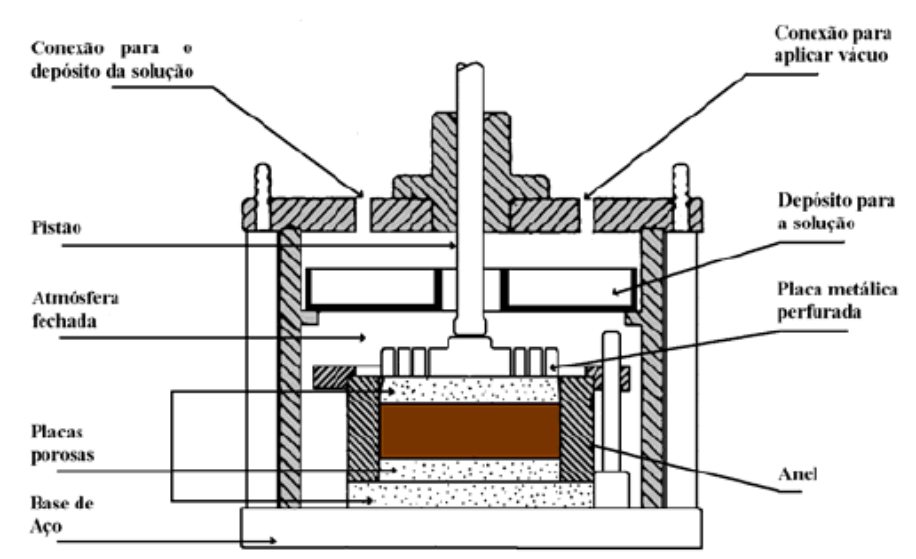

Figura 2.21 - Equipamento para ensaio edométrico utilizando a técnica de controle de sucção por imposição de umidade relativa (Esteban e Sáez, 1988, modificado de Soto, 2004).

O controle de sucção nestes ensaios de pressão de expansão se dá por meio da transferência de vapor, por imposição de umidade relativa. O ensaio consiste em colocar a amostra em contato com uma atmosfera de umidade relativa controlada de acordo com uma solução que proporciona a pressão de vapor determinada (Soto, 2004 e Pereira, 2004).

a) Trabalhos realizados com transferência de vapor para determinar a expansão.

Ensaios edométricos com sucção controlada a partir da imposição de umidade relativa por transferência de vapor foram realizados por Esteban (1990), Bernier et al. (1997), Vilar (1999), Cuisiner e Masrouri (2004). Esses autores alegaram que a desvantagem dessa técnica é o longo tempo requerido para estabilização da sucção das amostras, devido ao processo lento de umedecimento. Para reduzir esse tempo, alguns autores propuseram a utilização de aparatos para forçar a circulação do vapor de água, através de uma bomba de ar (Blatz e Graham 2000; Lloret et al. 2003; Dueck 2004; Jotisankasa et al. 2007).

Pintado et al. (2009) avaliaram a pressão de expansão em amostras de solo compactadas por meio do controle de sucção por imposição de umidade relativa. Os autores comentam que a escolha do tipo de solução, especialmente em ensaios com temperatura elevada, deve levar em conta a possibilidade de volatização da solução. Soluções voláteis podem se condensar nos tubos, nas pedras porosas ou nas próprias amostras de solo. No caso de ácido sulfúrico, a 
presença de soluções voláteis no ar podem alterar a composição mineralógica e danificar o ensaio.

Tang et al. (2011) estudaram o uso de um argilito compactado para substituir bentonita comercial, a fim de selar resíduos radioativos. O material apresentou pressão de expansão que pode ser proveniente da variação de volume ocorrida pela infiltração de água dos poros da rocha sã no material compactado. Para tanto, os autores analisaram a pressão de expansão por diversas metodologias, dentre essas o método a volume constante por imposição de umidade relativa, o método expansão-reconsolidação (swell-reload), e o método da expansão-zero (zero-swell). No método à volume constante foram utilizadas soluções salinas saturadas de $\mathrm{ZnSO}_{4} \cdot 7 \mathrm{H}_{2} \mathrm{O}$, com umidade relativa mantida em $91,3 \%$ à $20^{\circ} \mathrm{C}$, correspondendo à uma sucção de 12,6 MPa.

Os autores verificaram que a pressão de expansão depende do método de ensaio aplicado, e pode variar de 1 a $5 \mathrm{MPa}$. Os ensaios com os testes a volume constante permitiram observar que o comportamento expansivo durante o umedecimento é função da sucção, e que depende da forma e dos caminhos de hidratação.

Lee et al. (2012) analisaram a pressão de expansão de bentonitas compactadas em diferentes densidades secas face à diferentes concentrações de solução salina de $\mathrm{NaCl}$. As densidades variaram entre 1,5 a $1,7 \mathrm{~g} / \mathrm{cm}^{3}$, e as concentrações utilizadas foram de $0,04 \mathrm{M}$ e $0,4 \mathrm{M}$. Os ensaios foram conduzidos com a metodologia a volume constante, com duração de 30 dias para a estabilização da expansão. Os resultados mostraram que a pressão de expansão aumentou com o aumento da densidade. Em relação às concentrações de $\mathrm{NaCl}$, a expansão foi maior na concentração de $0,04 \mathrm{M}$, e a medida que aumentou para $0,4 \mathrm{M}$ essa pressão diminuiu.

Ferreira (2009) comenta que as medidas de algumas propriedades importantes para projetos de engenharia em solos expansivos são menos relevantes que os métodos de identificação. $\mathrm{Na}$ literatura existem muitas técnicas para determinação dessas propriedades, no entanto, em geral, não são representativas das mudanças que ocorrem em campo, particularmente com no que diz respeito a histórico de tensões e sucção.

É possível verificar que não há um método universal com melhor representatividade do fenômeno. Portanto, faz-se necessário analisar o comportamento desses materiais em teores de umidade variados com o controle da sucção e modos de umedecimento. 


\subsubsection{Outros Ensaios com Sucção Controlada}

O controle de sucção também é aplicado para analisar parâmetros de resistência e deformabilidade, e também, o potencial ao colapso. Algumas técnicas foram adaptadas para essas aplicações, das quais podem ser citados o ensaio de compressão triaxial e o cisalhamento direto.

\subsubsection{Compressão Triaxial com sucção controlada}

O ensaio de compressão triaxial é uma das técnicas mais refinadas para determinar parâmetros de resistência e deformabilidade de solos. Este ensaio garante a impermeabilização total da amostra, além do controle da drenagem do corpo de prova e medidas de poropressão.

Pinto (2000) descreve a técnica como sendo um ensaio na qual é aplicado um estado hidrostático de tensões e um carregamento axial sobre o corpo de prova cilíndrico de solo envolto com uma membrana de borracha. A câmara de ensaio é totalmente preenchida com água, na qual é aplicada uma pressão que caracteriza a pressão confinante, ou pressão de confinamento, que atua em todas as direções. O carregamento axial é realizado por meio da aplicação de forças no pistão que penetra na câmara. O ensaio é chamado de ensaio de deformação controlada (Figura 2.22).

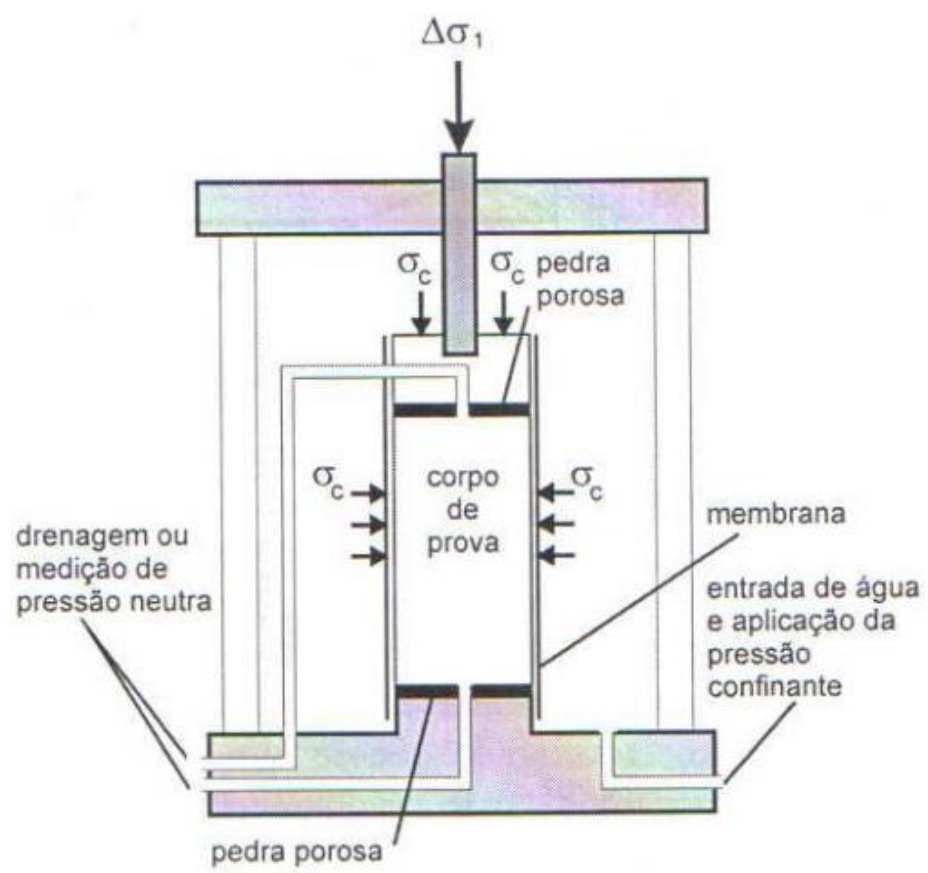

Figura 2.22 - Esquema do equipamento triaxial com controle de entrada e saída de água. 
Presa et al. (1991) descreve a modificação deste ensaio para a análise do comportamento deformacional de solos não saturados com o controle de sucção. A modificação na célula triaxial consiste em mudar o referencial de pressão através da técnica da translação de eixos aplicando pressão de ar na parte superior do corpo de prova. Dessa forma, é possível induzir a sucção desejada no solo.

O corpo de prova é alocado sobre uma pedra porosa saturada de alto valor de entrada de ar, que está em contato com o sistema de drenagem. As deformações verticais são obtidas por meio de transdutores de deslocamento.

\subsubsection{Cisalhamento Direto com Sucção Controlada}

Para o controle de sucção, as modificações realizadas na prensa convencional de cisalhamento direto estão descritas no trabalho realizado por Fonseca (1991). O equipamento é constituído por uma câmara de pressão que permite a aplicação de pressão de ar no topo do corpo de prova e também por meio da caixa de cisalhamento. A base da caixa é composta por uma pedra cerâmica porosa de alto valor de entrada de ar, por onde é aplicada uma pressão de água, e o corpo de prova é colocado sobre a mesma.

Os deslocamentos horizontais e verticais, as medidas de pressões de ar e água, as forças cisalhantes e o controle das forças verticais no corpo de prova são realizados por instrumentos elétricos como transdutores de deslocamento e pressão, e células de carga (Figura 2.23).

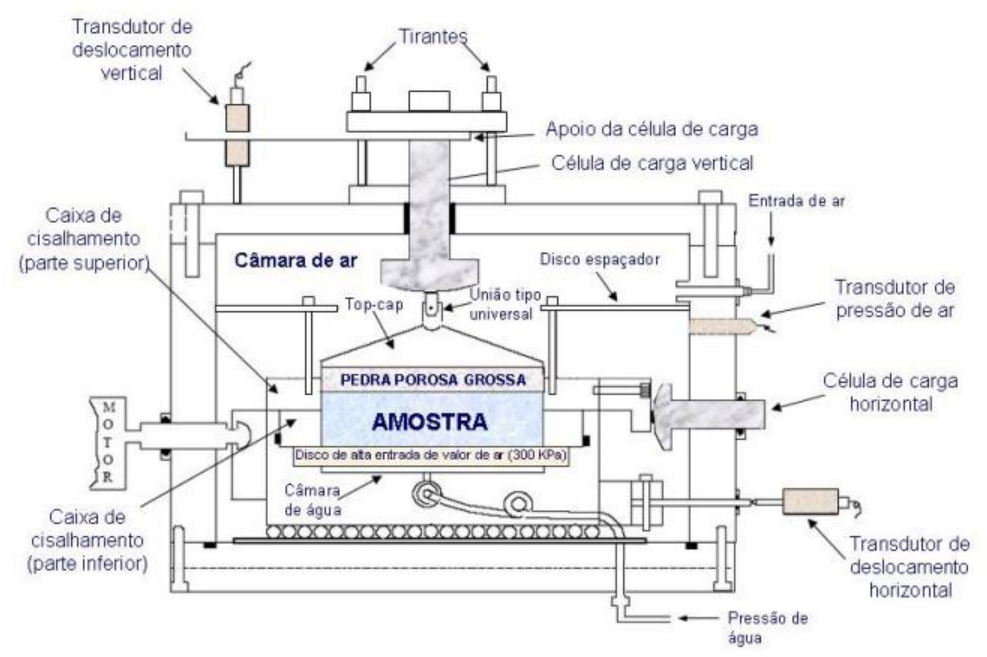

Figura 2.23 - Equipamento de cisalhamento direto com sucção controlada (Adaptado de Fonseca, 1991). 
Lopes (2007) analisou a influência da sucção na resistência ao cisalhamento de um solo residual da região metropolitana de Belo Horizonte $(\mathrm{MG})$ não saturado por meio de ensaios de cisalhamento direto. O equipamento utilizado foi o mesmo desenvolvido por Fonseca (1991). A autora analisou o comportamento em amostras indeformadas com teor de umidade natural, e apresentou algumas considerações sobre a sucção na compressibilidade do material. Foi verificado que a resistência aumenta para baixos valores de sucção matricial. Para valores elevados, o comportamento apresentou linearidade, o que permitiu o ajuste da envoltória para uma função hiperbólica.

\subsection{Correlações para Classificação de Solos Expansivos}

$\mathrm{Na}$ literatura, existem diversos autores que propuseram critérios de classificação do potencial de expansão, dentre eles: Seed et al.. (1962), Van der Merwe (1964), Fredlund et al. (1980), Chen (1988), Mc Keen (1992), entre outros.

Outros autores, como Alonso et al. (1992), Basma et al. (1995), Rao et al. (2006) relacionam a pressão de expansão com as propriedades índices do solo, sendo o teor de umidade, densidade, porcentagem de argila, limites de consistência e capacidade de troca catiônica, os mais utilizados.

O índice de expansão livre (FSI) proposto por Holtz e Gibbs (1956) é considerado como uma propriedade de um solo expansivo a qual reflete o respectivo potencial de expansão. O ensaio de FSI é realizado com solo seco em estufa passado na peneira $425 \mu \mathrm{m}$. É definido como razão entre a diferença de volume de solo, água e querosene ao volume de solos em querosene, expresso como:

$$
F S I=\frac{\left[\begin{array}{c}
(\text { volume final de solo em água })- \\
(\text { volume final de solo em querosene }) \times 100
\end{array}\right]}{\text { volume final de solo em querosene }}
$$

Solos com FSI > 200 são considerados com expansibilidade muito alta; FSI entre 100 e 200 são caracterizados com alta expansibilidade; FSI entre 5 e 100 com expansibilidade média, e FSI < 50 com baixa expansibilidade. Os autores consideram que as características de expansão previstas com o FSI devem ser consideradas como um parâmetro, ao invés de outra propriedade índice. 
Seed et al. (1962b), em estudo sobre as características de expansibilidade de argilas compactadas, desenvolveram um gráfico com base na "Atividade da Argila versus Percentual de Argila" (Figura 2.24).

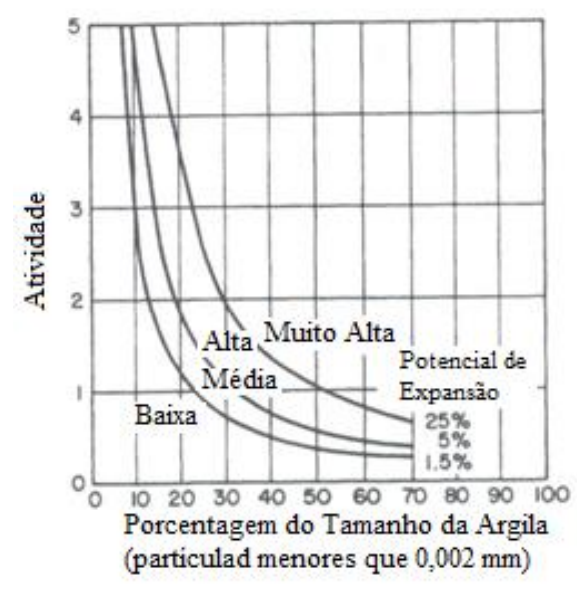

Figura 2.24 - Classificação do potencial de expansão proposto por Seed et al. (1962b).

Wiliams e Donaldson (1980) propuseram uma classificação quanto à expansibilidade que relaciona a porcentagem de argila com o índice de plasticidade do material (Figura 2.25).

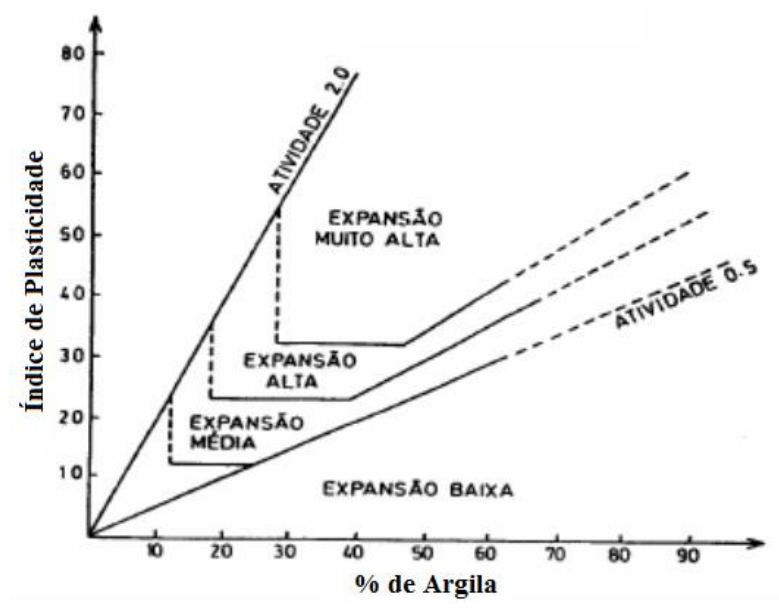

Figura 2.25 - Classificação da expansibilidade de materiais argilosos (Wiliams e Donaldson, 1980)

McKeen e Hamberg (1981) desenvolveram um sistema de classificação que combina as propriedades índices com a capacidade de troca de cátions (CTC). O sistema estendeu os conceitos de Pearring (1963) e Holt (1969), que desenvolveram um quadro de classificação que relaciona a mineralogia, a atividade da argila; e um novo parâmetro, a atividade de troca catiônica, expressa como: 


$$
A T C_{c}=C T C / \text { Teor de Argila }
$$

O sistema de classificação Pearing-Holt indica grupos mineralógicos de determinadas regiões em uma carta "Índice de Atividade versus Capacidade de Troca de Cátions", como mostra a Figura 2.26.

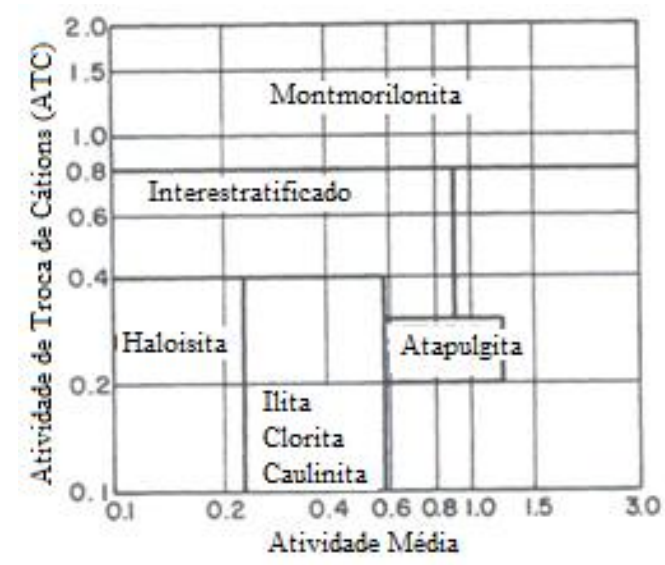

Figura 2.26 - Classificação mineralógica proposta por Pearing (1963) e Holt (1969).

Pereira e Pejon (1999) propuseram a avaliação do potencial de expansão de solos e rochas através do valor de adsorção de azul de metileno (VB) versus \% de argila. Os autores basearam-se no estudo do potencial expansivo da Formação Guabirotuba no estado do Paraná, e substituíram o índice de plasticidade pelo VB. Neste gráfico foi possível delimitar área de predominância de materiais com o potencial expansivo em: muito alto, alto, médio e baixo (Figura 2.27).

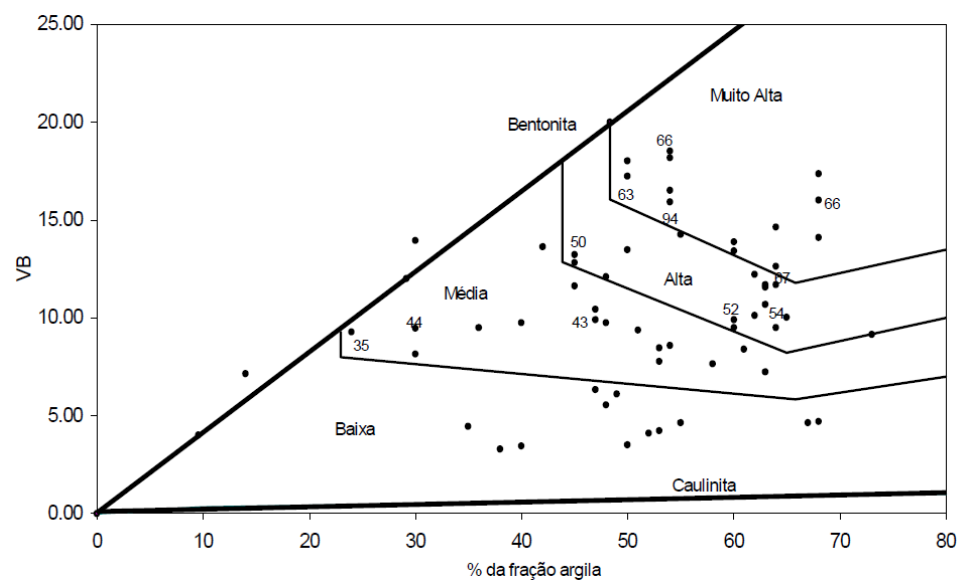

Figura 2.27 - Representação dos valore de VB versus porcentagem de fração argilosa, com os respectivos valores de expansão livre (\%) (Pereira e Pejon, 1999, modificado de Pereira 2004). 
Após obterem resultados satisfatórios a partir dessa análise, os autores aprimoraram a relação “\% de argila versus VB versus expansão" para cada sucção imposta, gerando um Índice Mineralógico (IM) expresso na seguinte equação:

$$
I M=\frac{\% \operatorname{argila} * V B}{100}
$$

Os dados de IM e pressão de expansão foram plotados em um gráfico, a fim de analisar a influência da mineralogia na expansão dos materiais estudados pelos autores de acordo com o aumento de sucção. A Figura 2.28 mostra que a sucção aumenta, e os atributos mineralógicos diminuem na previsão do potencial expansivo dos materiais.

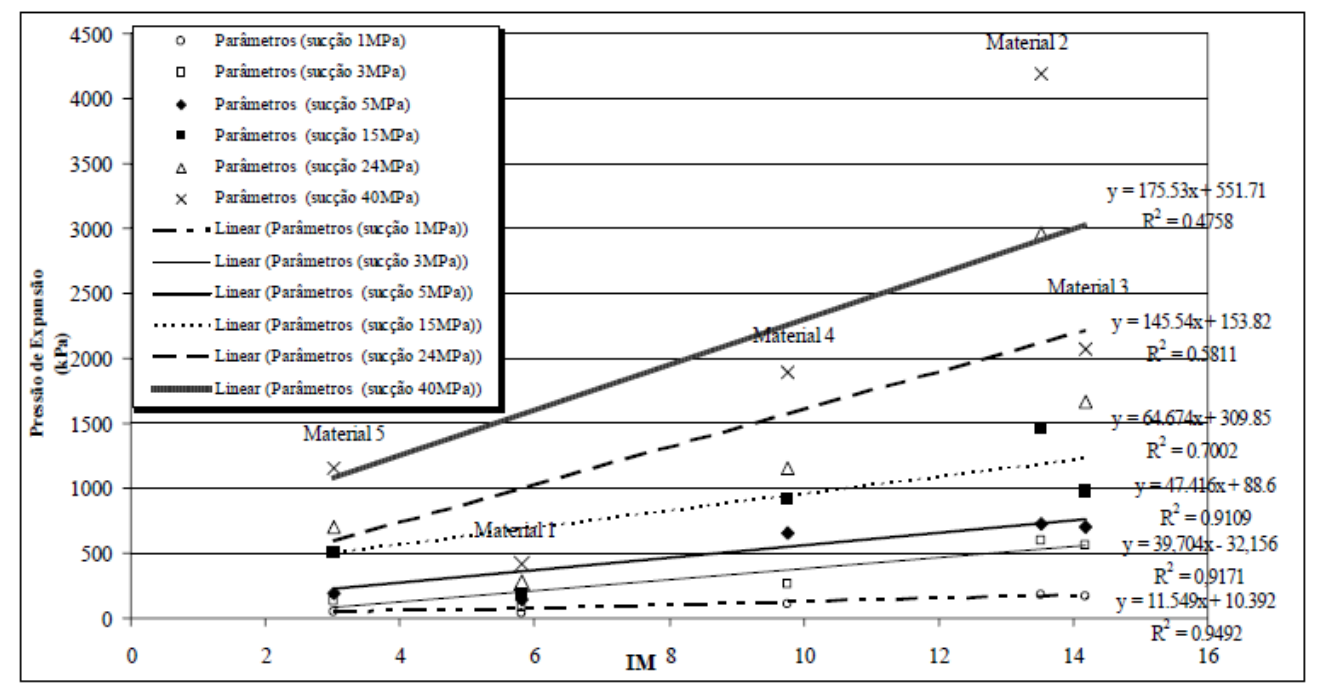

Figura 2.28 - Resultados de IM versus Pressão de Expansão para diferentes sucções impostas (Pereira, 2004).

Com esses resultados de IM, os autores optaram por incorporar uma relação entre os parâmetros provenientes dos índices físicos ( $\rho \mathrm{d})$, índices de consistência (IP), granulometria (\% argila) e índices físico-químicos (VB) versus resultados de Pressão de Expansão para cada sucção imposta. A correlação desses parâmetros é apresentada na equação (2.19):

$$
I C M=\frac{I P * \rho_{d} * \% \operatorname{argila} * V B}{10.000}
$$

Onde, ICM = índice característico dos materiais.

Os dados dos índices ICM para cada material versus pressão de expansão (kPa) correspondentes às sucções impostas foram plotados em um gráfico e estão mostrados na Figura 2.29. 


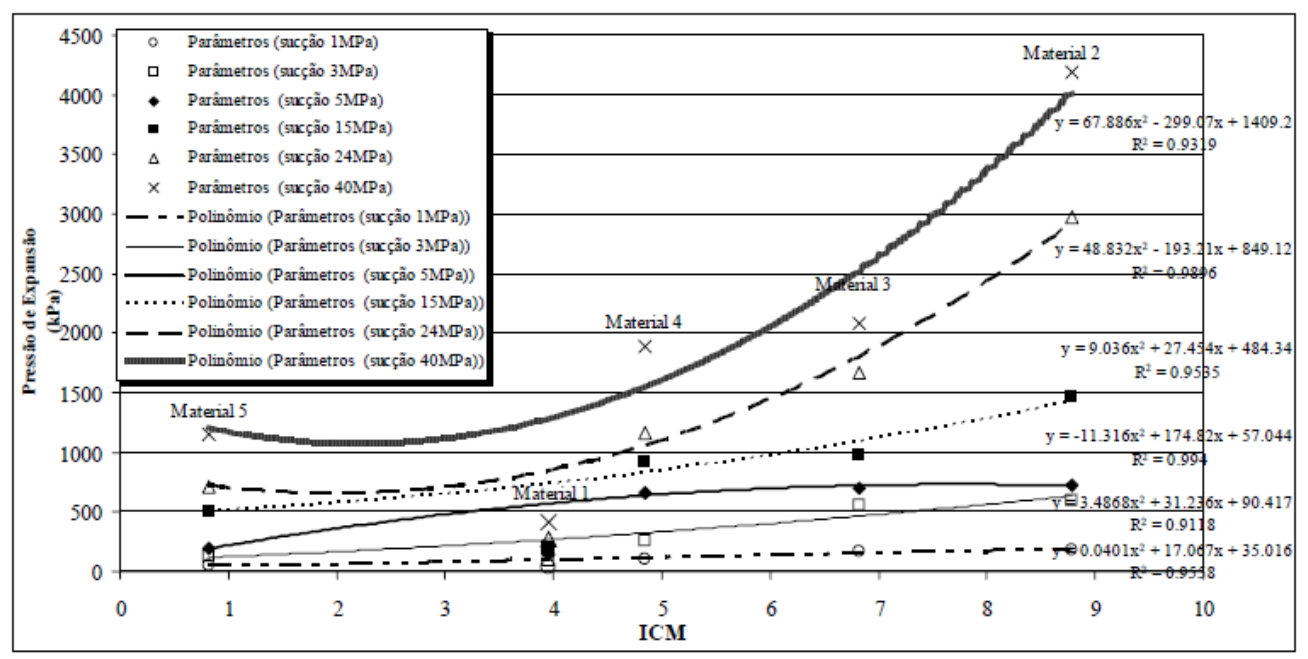

Figura 2.29 - Resultados de ICM e Pressões de Expansão para as diferentes sucções impostas (Pereira, 2004).

Há um consenso geral que a pressão de expansão aumenta com o aumento da densidade, aumento da porcentagem de argila e diminuição do teor de umidade (Tomas et al., 2000; Erzin e Erol, 2004; Rao et al., 2004).

PraKash e Sridharan (2004) estudaram uma simples abordagem baseada no índice de expansão livre, para classificar o solo quanto a expansibilidade. A metodologia leva em consideração a razão entre o volume de sedimentos em equilíbrio de $10 \mathrm{~g}$ de solo seco imerso em água destilada $\left(\mathrm{V}_{\mathrm{d}}\right)$, em relação ao volume de sedimentos em equilíbrio imerso em tetra cloreto de carbono ou querosene $\left(\mathrm{V}_{\mathrm{k}}\right)$. $\mathrm{O}$ índice de expansão livre (FSR) é calculado então:

$$
F S R=\frac{V_{a}}{V_{K}}
$$

Vale ressaltar também, que esta técnica além de classificar quanto à expansão, ainda leva em consideração o tipo de argilomineral presente, como mostra a Tabela 2.10. 
Tabela 2.10 - Classificação dos solos baseado no índice de expansão livre (Prakash e Sridharan, 2004).

\begin{tabular}{cccc}
\hline $\begin{array}{c}\text { Índice de Expansão } \\
\text { Livre (FSR) }\end{array}$ & $\begin{array}{c}\text { Expansibilidade do } \\
\text { Solo }\end{array}$ & Tipo de Argila & $\begin{array}{c}\text { Tipo de Argilomine ral } \\
\text { Dominante }\end{array}$ \\
\hline$\leq 1,0$ & Insignificante & Não Expansiva & Caulinita \\
$1,0-1,5$ & Baixo & $\begin{array}{c}\text { Mistura de Expansiva } \\
\text { com Não expansiva }\end{array}$ & Caulinita + Montmorilonita \\
& Moderado & Expansiva & Montmorilonita \\
$1,5-2,0$ & Alto & Expansiva & Montmorilonita \\
$2,0-4,0$ & Muito Alto & Expansiva & Montmorilonita \\
$>4,0$ & & & \\
\hline
\end{tabular}

Outros autores também propuseram correlações para o potencial expansivo e pressão de expansão envolvendo as propriedades índices e as condições da amostra. Algumas correlações são apresentadas na Tabela 2.11 .

Tabela 2.11- Correlações para características de expansão (Rao et al., 2004).

\begin{tabular}{|c|c|c|c|}
\hline Quantificação & Referência & Parâmetros & Equações \\
\hline Potencial de Expansão, S (\%) & Vijay vergiy a \& Ghazzaly (1973) & $\begin{array}{l}\text { Limite de Liquidez }(\%), \mathrm{w}_{\mathrm{L}} \\
\text { Densidade Seca Máxima, }\left(\mathrm{kN} / \mathrm{cm}^{3}\right), \gamma_{\mathrm{d}}\end{array}$ & $\log S=1 / 19,5\left(\gamma_{d}+0,65 w_{L}-130,5\right)$ \\
\hline Potencial de Expansão, S (\%) & Nay ak \& Christensen (1974) & $\begin{array}{l}\text { Index de Plasticidade }(\%), \mathrm{I}_{\mathrm{p}} \\
\text { Teor de Umidade, }(\%), \mathrm{w}_{\mathrm{i}} \\
\text { Teor de Argila }\end{array}$ & $\mathrm{S}=2,3 \times 10^{-2}(\mathrm{Ip})^{1,45} \mathrm{C} / \mathrm{w}_{\mathrm{i}}+6,4$ \\
\hline Pressão de Expansão, $\left(\mathrm{kg} / \mathrm{cm}^{2}\right), P_{s}$ & Komornik \& David (1969) & $\begin{array}{l}\text { Limite de Liquidez (\%), wL } \\
\text { Densidade Seca Máxima, }\left(\mathrm{kN} / \mathrm{cm}^{3}\right), \gamma \mathrm{d} \\
\text { Teor de Umidade, }(\%) \text { wi }\end{array}$ & $\log P_{s}=-2,1+0,021 w_{L}+0,00067 \gamma_{d}-0,027 w_{i}$ \\
\hline Pressão de Expansão, $\left(\operatorname{ton} / \mathrm{ft}^{2}\right), P_{s}$ & Vijay vergiy a \& Ghazzaly (1973) & $\begin{array}{l}\text { Limite de Liquidez }(\%), \mathrm{wL} \\
\text { Densidade Seca Máxima, }\left(\mathrm{lb} / \mathrm{ft}^{3}\right), \gamma \mathrm{d}\end{array}$ & $\log P_{s}=1 / 19,5\left(\gamma_{d}-0,65 w_{L}-139,5\right)$ \\
\hline Pressão de Expansão, $\left(\mathrm{lb} / \mathrm{inch}^{2}\right), P_{s}$ & Nay ak \& Christensen (1974) & $\begin{array}{l}\text { Index de Plasticidade (\%), Ip } \\
\text { Teor de Umidade, (\%), wi } \\
\text { Teor de Argila }\end{array}$ & $\mathrm{P}_{\mathrm{s}}=3,6 \times 10^{-2}(\mathrm{Ip})^{1,12} \mathrm{C}^{2} / \mathrm{w}_{\mathrm{i}}^{2}+3,8$ \\
\hline
\end{tabular}




\section{MATERIAIS E MÉTODOS}

Neste capítulo apresenta-se a caracterização dos materiais utilizados nesta pesquisa, bem como, os ensaios de caracterização e a metodologia adotada para realização dos ensaios de expansão. Descreve-se, também, o equipamento desenvolvido e os respectivos dispositivos para medição da pressão de expansão com controle de sucção.

\subsection{Características dos Materiais Estudados}

\subsubsection{Formação Corumbataí}

A Formação Corumbataí aflora na bacia hidrográfica do rio Corumbataí, situada na porção nordeste da Bacia Sedimentar do Paraná, na Depressão Periférica Paulista, centro-leste do Estado de São Paulo (Perinotto e Lino, 2014). Essa formação situa-se acima da Formação Irati, constituindo a camada superior do Grupo Passa Dois, a última Era Paleozóica.

No Estado de São Paulo, esta formação apresenta-se, em geral, com espessura inferior a 150 metros, que se reduz para norte, até se anular próximo ao limite com o Estado de Minas Gerais (Campos, 1989).

Esta formação geológica tem como principal unidade litológica os siltitos e argilitos cinzaavermelhados/esverdeados e arroxeados. Essas rochas são intercaladas, também, por lentes e camadas de arenitos muito finos, além de intercalações carbonáticas. As estruturas sedimentares são estratificadas do tipo plano-paralelas, cruzadas e de baixo ângulo, marcas onduladas, fraturas de ressecamento e brechas intra formacionais (Campos, op. Cit.).

A região tipo de ocorrência dessa formação é a bacia hidrográfica do mesmo nome, localizada no estado de São Paulo, nas regiões de Rio Claro, Piracicaba, Limeira e Pirassununga, e aflora em uma área de aproximadamente $1.500 \mathrm{~km}^{2}$ (Figura 3.1).

De acordo com diversos autores, os horizontes de argila presentes na Formação Corumbataí pertencem aos grupos da montmorilonita, ilita e caulinita. Essa variação da determinação da composição mineralógica deve-se à própria variação dos ambientes de sedimentação e aos processos de alteração após a deposição (Musso, 2004). 

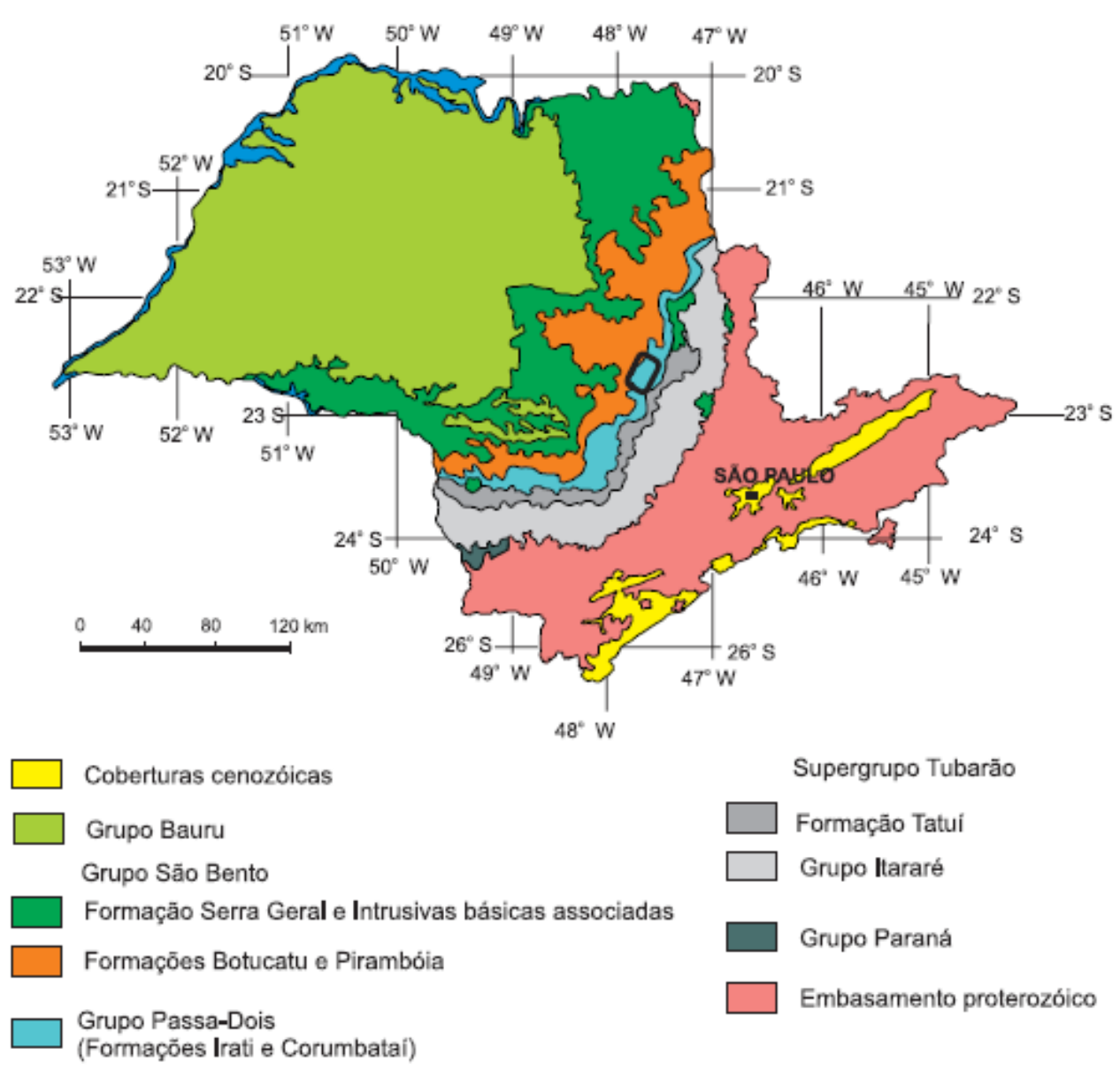

Figura 3.1 - Localização das cidades onde afloram os materiais da Formação Corumbataí e da Formação Botucatu no Estado de São Paulo (Perinotto et al., 2008).

\subsubsection{Formação Botucatu}

A Formação Botucatu aflora na região central do Estado de São Paulo, mais precisamente nas serras basálticas. As amostras de solo dessa formação, utilizadas nesta pesquisa, foram coletadas por Loch (2013), no município de São Carlos.

O autor comenta que Muro (2000) e outros caracterizam essa unidade geológica pela constituição de arenitos de granulação fina a média, de cor avermelhada, com grãos bem selecionados e de alta esfericidade, sendo muito friáveis ou silicificados. As estruturas predominantes são estratificações cruzadas de médio a grande porte, podendo atingir até $15 \mathrm{~m}$ de altura. Essa formação ocupa uma área de aproximadamente $60 \%$ da superfície total no município de São Carlos, em São Paulo. 


\subsubsection{Bentonita}

A bentonita utilizada neste trabalho é proveniente de minas localizadas no município de Boa Vista no estado da Paraíba, comercializadas pela empresa de exploração mineral DRESCON S/A. Silva (2011) comenta que essa bentonita é aplicada como aditivo em fluidos de perfuração de petróleo, visto que, por serem sódicas apresentam elevado índice de inchamento e alta capacidade de troca de cátions.

\subsection{Metodologia}

\subsubsection{Coleta de Amostras}

As amostras de sedimentos da Formação Corumbataí foram coletadas em taludes de corte na Rodovia Irineu Penteado que dá acesso à cidade de Ipeúna, no interior do estado de São Paulo nas coordenadas UTM 223057 E e 7.517.776 N, zona 23 Sul.

Os materiais dessa formação apresentam problemas de desagregabilidade e, portanto, exibem fissuramento no qual influencia diretamente nas propriedades mecânicas. Por este fato, para a realização de uma amostragem representativa de blocos de rocha indeformados sem fraturamento e fissuras, optou-se por uma escavação manual cuidadosa sem o uso da caixa metálica de molde, visto que, a umidade das amostras não estava nas condições almejadas para a moldagem. Desse modo, na tentativa de se coletar amostras com umidade natural, foi necessária a remoção de camadas superficiais expostas ao sol que estavam extremamente ressecadas.

A escavação foi avançada até que fosse possível a obtenção de blocos íntegros sem desagregação, como mostra a Figura 3.2. A retirada dos blocos foi realizada a partir dos planos de acamamento evitando o fraturamento.

Imediatamente após a moldagem, os blocos foram alocados em uma base de madeira para a aplicação de uma camada de parafina. A fim de garantir a integridade e manter o teor de umidade de campo, após o parafinamento, selaram-se os mesmos com plástico filme. Em seguida, os materiais foram transportados para o laboratório, e armazenados em câmara úmida. 


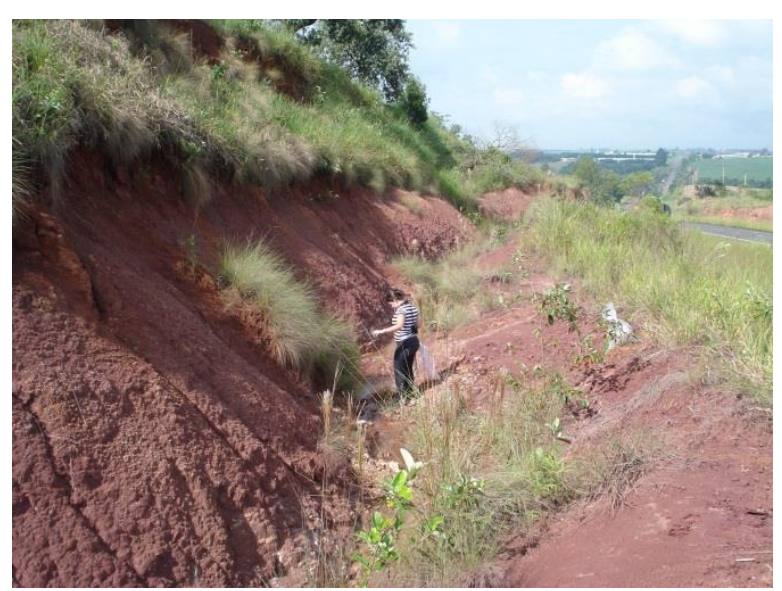

(a)

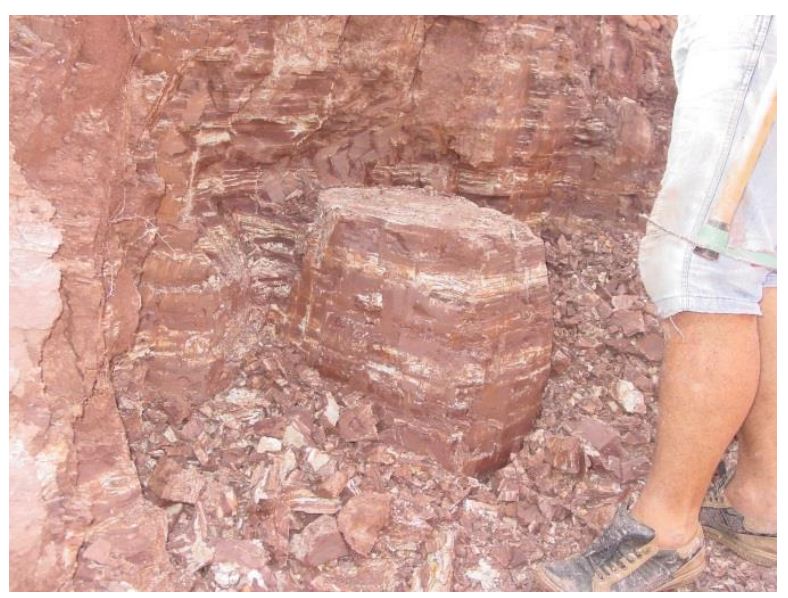

(c)

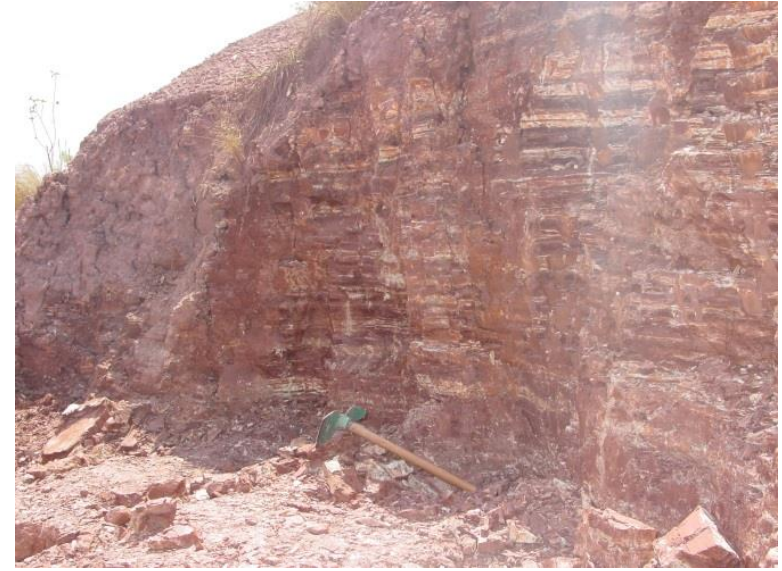

(b)

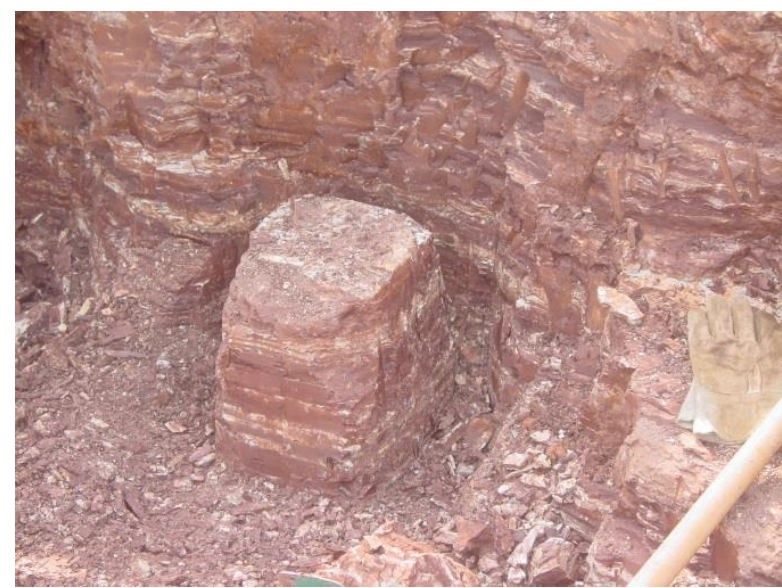

(d)

Figura 3.2 - Coleta de amostras da Formação Corumbataí: (a) Talude às margens da rodovia, onde foram retiradas as amostras; (b) Detalhamento e aspecto geral da abertura feita no talude; (c) Moldagem do bloco indeformado; (d) Bloco moldado.

A Figura 3.2(b) permite visualizar a presença de siltitos argilosos carbonáticos, de cor predominantemente avermelhada, com bancos esbranquiçados. Neste local, ficou evidente o fenômeno de empastilhamento originado pelo desconfinamento da abertura no talude.

As amostras deformadas oriundas de fragmentos da rocha sedimentar foram coletadas diretamente em sacos plásticos, seladas e transportadas até o laboratório para determinação do teor de umidade natural e realização dos ensaios de caracterização e expansão.

Posterior à amostragem, os fragmentos coletados referentes à amostra deformada foram levados a uma máquina com rolo compressor a fim de desagregar o material, até que o mesmo fosse reduzido a pó, semelhate a um silte. Esse processo foi realizado para obtenção do 
material fino para determinação das características expansivas nas condições de material desagregado e compactado.

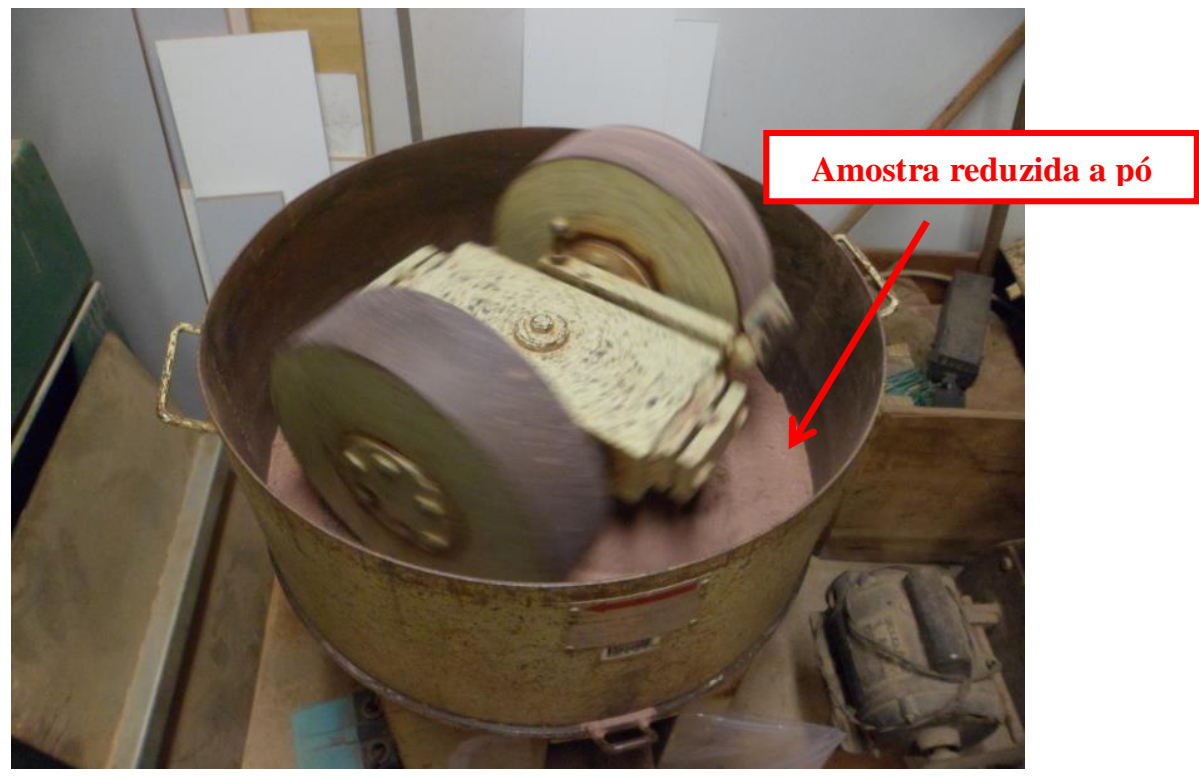

Figura 3.3 - Máquina de moagem e desfragmentação do material da Formação Corumbataí.

\subsubsection{Ensaios de Caracterização Geotécnica}

As amostras estudadas foram caracterizadas por meio de ensaios de distribuição granulométrica (ABNT NBR 7181:1984) e massa específica dos sólidos $\left(\rho_{\mathrm{s}}\right)$ (ABNT NBR 6508:1984). Foi realizado, também, o ensaio de compactação na energia Proctor Normal (ABNT NBR 7182:1986) para determinação na massa específica aparente seca máxima $\left(\rho_{\text {dmáx }}\right)$ e umidade ótima ( $\left.w_{\text {ót. }}\right)$. Os demais índices físicos foram calculados a partir de fórmulas que permitem a correlação.

Os ensaios para determinação dos Limites de Consistência foram realizados de acordo com as normas ABNT NBR 6459:1980 (Limite de Liquidez) e NBR 9180:1982 (Limite de Plasticidade).

\subsubsection{Ensaios de Caracterização Mineralógica}

\subsubsection{Análise Térmica Diferencial}

A análise térmica diferencial (ATD) é uma técnica aplicada na identificação de argilominerais que consiste no aquecimento de uma argila, a velocidade constante, juntamente com uma substância termicamente inerte (geralmente o óxido de alumínio-alfa ou coríndon). Este ensaio demonstra as diferenças de temperatura entre o padrão inerte e a argila em estudo. $\mathrm{O}$ 
resultado é lançado sob a forma de gráfico onde uma curva de reação, chamada de curva termo diferencial ou termograma, registra as variações de temperatura na amostra, decorrentes das modificações físico-químicas. Os picos que aparecem no termograma são função da composição química e estrutura cristalina do argilomineral analisado. Quando ocorrem reações endo ou exotérmicas, estes picos apresentam-se como deflexões em sentidos opostos no termograma.

O ensaio de ATD foi realizado no Laboratório de Geotecnia Ambiental - Departamento de Geotecnia, da Escola de Engenharia de São Carlos - Universidade de São Paulo (USP), por meio do equipamento BP Engenharia, modelo RB 3000-20.

Nesta pesquisa, este ensaio foi realizado conforme as recomendações de Santos (1989). Para o ATD utilizou-se de 2 a $3 \mathrm{~g}$ do material, com velocidade de aquecimento de $12,5^{\circ} \mathrm{C} / \mathrm{min}$.

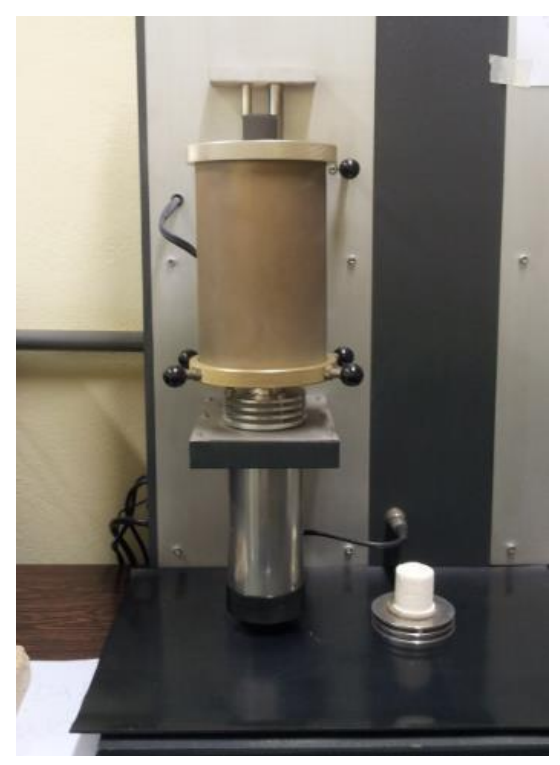

Figura 3.4 - Equipamento para ensaio de Análise Térmica Diferencial.

\subsubsection{Difração de raios-x (DRX)}

Esta técnica permite estudar a estrutura cristalina dos materiais, realizando-se a classificação e identificação dos grupos dos argilominerais a partir da medição da distância interplanar basal do argilomineral. Foram ensaiadas as amostras provenientes das Formações Corumbataí e Botucatu, e também a amostra de bentonita pura.

Esses ensaios foram realizados no Laboratório de Difração de Raios-x do Instituto de Física de São Carlos/USP, por meio de um difratômetro automático, Rigaku Rotaflex, modelo RU- 
200B com tubo de Cobre $(\mathrm{Cu})$. As lâminas orientadas para a análise de DRX foram preparadas da forma descrita a seguir:

As amostras foram destorroadas em almofariz e em seguida colocadas em suspensão em uma solução com defloculante (Hexametafosfato de sódio - concentração de 45 g/l). A suspensão foi agitada mecanicamente por dez minutos e em seguida deixada em repouso por 12 horas. Após este tempo a amostra foi novamente agitada mecanicamente por mais cinco minutos. Foram utilizadas lâminas de vidro com dimensões de 4 x $2 \mathrm{~cm}$ como suporte para deposição do material. Essas lâminas foram colocadas em um recipiente com um suporte no fundo que serve como apoio. O material foi então transferido para o recipiente até recobrir totalmente o suporte. Aguarda-se, então, um tempo de 2 minutos, e em seguida introduz-se a lâmina onde será depositado o material para a análise por difração de raios-X. Foram analisadas três lâminas, as quais contemplaram: uma lâmina com amostra sem tratamento especial; uma lâmina com amostra aquecida à $550^{\circ} \mathrm{C}$; e uma lâmina com amostra tratada com etilenoglicol por meio de solvatação.

\subsubsection{Microscopia Eletrônica de Varredura (MEV)}

As amostras de solo deformadas e indeformadas foram submetidas ao ensaio de microscopia eletrônica de varredura (MEV) a fim de observar a microestrutura, textura, vazios e identificação dos possíveis argilominerais presentes na fração fina.

Os ensaios foram realizados no Laboratório de Caracterização Estrutural (LCE) Departamento de Engenharia de Materiais (DEMa), da Universidade Federal de São Carlos (UFSCar), por meio do aparelho denominado "FEI Inspect $S$ 50", o qual é acoplado à um sistema de Espectrômetro de Dispersão de Energia de Raios X (EDS).

Para a realização do MEV, as amostras foram preparadas em pequenas porções e fixadas com cola incolor em pinos de alumínio (“stub”) com dimensões padronizadas. Em seguida, o conjunto amostra + stub foi colocado em estuda a $60^{\circ} \mathrm{C}$ para garantir a perfeita secagem (Figura 3.5). 


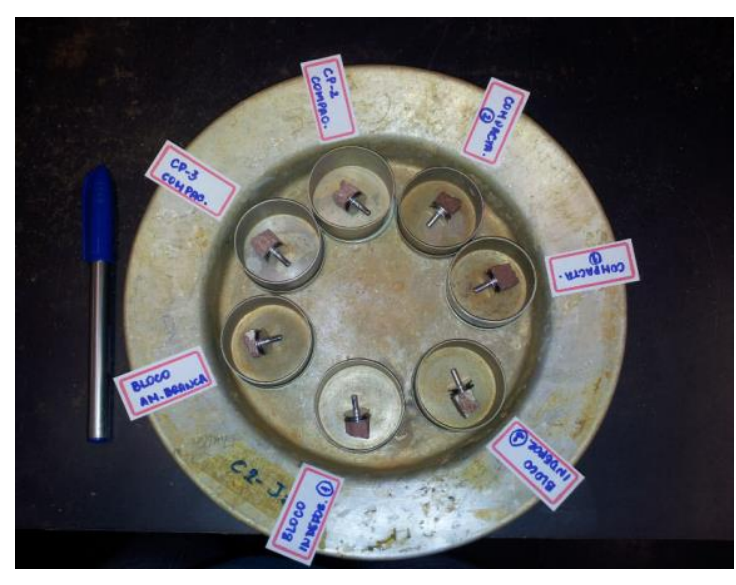

(a)

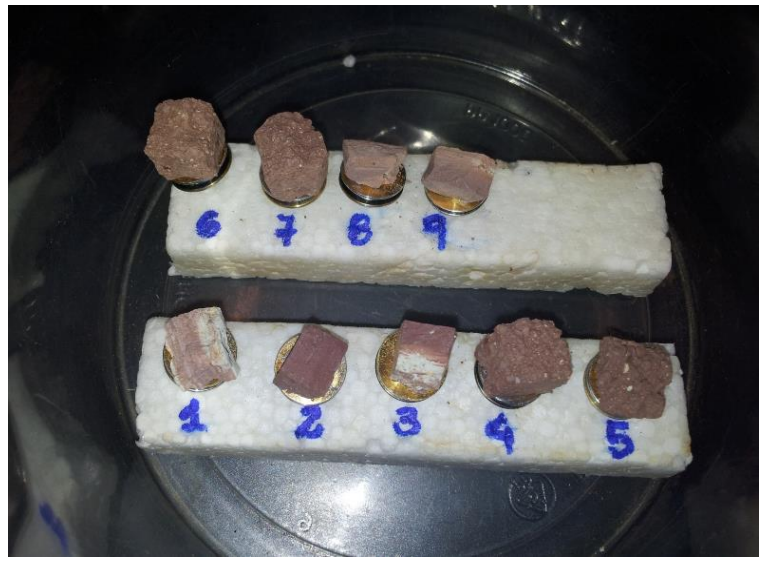

(b)

Figura 3.5 - (a) Amostras coladas nos stubs antes de secar em estufa; (b) Amostras secas para ensaio.

Após secagem em estufa, as amostras foram submetidas a um banho metálico de ouro. Esse procedimento consiste em depositar uma camada do material metálico que seja suficientemente fina de maneira que não seja vista pelo microscópio, e ao mesmo tempo trabalhe como condutora, permitindo, assim, uma boa definição para a imagem.

Para cada uma das amostras foram obtidas imagens com aumentos de 1.000 até 10.000 vezes. Em alguns casos onde foram observados vazios e texturas peculiares os aumentos variaram entre 10.000 vezes e 20.000 vezes.

\subsubsection{Adsorção de Azul de Metileno pelo Método da Mancha}

De forma complementar aos ensaios realizados para identificação dos argilominerais, realizou-se também o ensaio de adsorção de azul de metileno proposto por Lan (1977) e adaptado por Pejon (1992).

No que se refere á fração granulométrica, os autores utilizam partículas de dimensões inferiores a $0,5 \mathrm{~mm}$, e a adaptação proposta sugere que se utilizem amostras que passam na peneira de 2,0 mm, permitindo assim a obtenção de um índice de adsorção de azul de metileno global, o que torna o ensaio de simples execução e evita a necessidade de execução do ensaio de granulometria.

Em relação à concentração da solução de azul de metileno utilizou-se ao invés de $10 \mathrm{~g} / \mathrm{L}$ uma concentração de 1,5 g/L, devido ao fato de que os solos de regiões tropicais apresentam a fração argilosa constituída predominantemente por minerais de baixa capacidade de adsorção, o que permite maior precisão nas determinações. 
Inicialmente deve-se pesar uma quantidade entre 0,5 a 1,0 g de cada amostra em um becker $(100 \mathrm{~mL})$, em seguida adicionar $10 \mathrm{~mL}$ de água destilada, e colocar o becker sobre o agitador magnético, mantendo em agitação por cerca de três minutos. Após o tempo de agitação, adicionar $1 \mathrm{~mL}$ da solução de azul de metileno (concentração de 1,5 g/L). Manter a solução em agitação constante por $30 \mathrm{~s}$. Em seguida retirar uma gota da suspensão com um bastão de vidro e colocar sobre o papel filtro. O teste é considerado positivo quando é formada uma auréola azul clara ao redor do círculo escuro. Caso o teste seja negativo, adicionar mais $1 \mathrm{~mL}$ de azul de metileno, aguardar 30 segundos e repetir o teste em papel filtro. Continuar o procedimento até que o teste seja positivo. Caso o teste seja positivo, aguardar durante três minutos e realizar novamente o teste. Se for positivo o ensaio está encerrado. Caso negativo, adiciona-se mais $1 \mathrm{~mL}$ de azul de metileno e prossegue-se o ensaio até novo teste positivo. $\mathrm{O}$ resultado é considerado positivo se uma auréola azul clara permanecer, assim, o ensaio pode ser considerado encerrado.

Após o ensaio, é possível determinar os parâmetros necessários para caracterizar os minerais presentes na amostra. A capacidade de troca de cátions (CTC) é calculada de acordo com a seguinte equação:

$$
C T C=\frac{V \cdot C \cdot 100}{M}
$$

onde,

$$
\begin{aligned}
& \mathrm{CTC} \rightarrow \text { meq/100g ou cmol+/kg } \\
& \mathrm{V} \rightarrow \text { Volume da solução de azul de metileno }(\mathrm{mL}) \\
& \mathrm{C} \rightarrow \text { Concentração da solução }(\mathrm{N}) \\
& \mathrm{M} \rightarrow \text { Massa de solos seca }(\mathrm{g})
\end{aligned}
$$

A superfície específica é calculada de acordo com a equação abaixo:

$$
S E=\frac{3,67 \cdot V}{M}
$$

onde,

$$
\begin{aligned}
& \mathrm{SE} \rightarrow \text { Superfície específica do material }\left(\mathrm{m}^{2} / \mathrm{g}\right) \\
& \mathrm{V} \rightarrow \text { Volume da solução de azul de metileno }(\mathrm{mL}) \\
& \mathrm{M} \rightarrow \text { Massa do solo seco }(\mathrm{g})
\end{aligned}
$$

O valor de azul de metileno é calculado de acordo com a seguinte equação: 


$$
V_{b}=\frac{1,5 \cdot V \cdot 100}{M \cdot 1000}
$$

onde,

$$
\begin{aligned}
& \mathrm{V} \rightarrow \text { Volume de azul de metileno }(\mathrm{mL}) \\
& \mathrm{M} \rightarrow \text { Massa de solo seco }(\mathrm{g})
\end{aligned}
$$

Para a determinação da capacidade de troca de cátions da bentonita pelo método da mancha utilizou-se uma concentração de $5 \mathrm{~g} / \mathrm{L}$ de Azul de Metileno com $0,5 \mathrm{~g}$ de material devido à sua elevada CTC. Neste caso, a superfície específica foi calculada a partir da seguinte equação:

$$
S E=\frac{12,23 \cdot V}{M}
$$

E o valor de azul de metileno calculado com a equação:

$$
V_{b}=\frac{5 \cdot V \cdot 100}{M \cdot 1000}
$$

\subsubsection{Porosimetria por Intrusão de Mercúrio}

O ensaio de porosimetria por intrusão de mercúrio foi realizado no Instituto de Física de São Carlos (IFSC) da Universidade de São Paulo (USP), através do equipamento PoreSizer 9320 da Micrometrics Instrument Corporation. A capacidade máxima de pressão de injeção do mercúrio é de 30.000 psi, a qual permite o preenchimento de poros maiores que $60 \AA$.

As amostras submetidas ao ensaio de porosimetria compreendem quatro condições:

(1) Amostras indeformadas da Formação Corumbataí nas condições: seca ao ar, e amostras estabilizadas nas sucções de 40.000, 25.000, 10.000 e $5.000 \mathrm{kPa}$, antes e após o ensaio de expansão inundada.

(2) Amostras compactadas da Formação Corumbataí nas condições: compactada na umidade ótima e seca ao ar; compactada seca (pó), e posteriormente seca ao ar; e estabilizadas nas sucções de 40.000, 25.000, 10.000 e 5.000 kPa, antes e após o ensaio de expansão inundada.

(3) Amostras da Formação Corumbataí secas, na forma de pó, misturadas com bentonita, compactadas nas proporções: $70 \%, 50 \%, 30 \%, 10 \%$ e 5\% de bentonita, somente antes do ensaio de expansão. 
(4) Amostras da Formação Botucatu secas, misturadas com bentonita e compactadas nas proporções: $70 \%, 50 \%, 30 \%$ de bentonita, somente antes do ensaio de expansão.

\subsubsection{Curva de Retenção}

A curva de retenção de água das amostras foi determinada pelo processo de secagem (drenagem) e umedecimento pelo Método do Papel Filtro (Marinho, 1995) e pelo Método do Dessecador à Vácuo. A curva de retenção permite avaliar os níveis de sucção em função da variação de umidade do material. A quantidade de água foi analisada em termos de umidade gravimétrica (\%), pois tem melhor representação para solos com alto potencial de deformação.

Os dados experimentais das curvas de retenção foram ajustados por modelos matemáticos propostos por Van Genuchten (1980) e Fredlund \& Xing (1994) a partir do programa computacional Grapher 6.0.

\subsubsection{Método do Papel Filtro}

De acordo com Fredlund e Rahardjo (1993), o método do papel filtro permite obter medidas de sucção matricial e sucção total. Quando o fluxo capilar, ocorrido entre as partículas de solo e as fibras do papel, interage com a água nos poros mede-se a sucção matricial. Quando as moléculas de água têm que escapar da água dos poros vencendo as forças capilares no solo e eventual força osmótica, ocorre o fluxo de vapor. Neste caso, a medida obtida é a sucção total. Assim, a metodologia para determinação da sucção matricial é realizada com o contato direto do papel filtro na amostra. Já para a determinação da sucção total, coloca-se uma malha ou rede entre o papel filtro e amostra para garantir o não contato entre os mesmos.

Na determinação da sucção total e matricial, após embalar o "conjunto" papel filtro-amostrapapel filtro ou papel filtro-malha-amostra-malha-papel filtro, o mesmo é isolado do ambiente externo em saco plástico na câmara úmida por sete dias até atingir equilíbrio entre o fluxo de água do solo para o papel. Após este período, determina-se a umidade do papel filtro, e a sucção é conhecida através da curva de calibração do papel filtro, em função das respectivas umidades do solo.

A sucção matricial foi determinada em amostras na condição indeformada e compactada na umidade ótima em amostras da Formação Corumbataí, tanto para trajetórias de secagem, como para trajetórias de umedecimento. A sucção total foi determinada, também, para o 
mesmo material, em amostras indeformadas e compactadas na umidade ótima, neste caso somente para trajetórias de umedecimento.

\section{- Processo de Secagem}

Para as condições indeformada e compactada na umidade ótima, o ensaio teve início a partir do processo de secagem, onde a amostra encontra-se saturada. Foram moldados 16 corpos de prova cilíndricos para cada condição, sendo que as amostras indeformadas foram talhadas diretamente dos blocos indeformados, e as amostras deformadas foram compactadas na umidade ótima diretamente no cilindro de PVC por meio do processo de compactação com uma prensa semelhante ao descrito por Souza (2009). Em seguida, os corpos de prova foram colocados sobre uma pedra porosa parcialmente submersa em água destilada para atingir a saturação (Figura 3.6). O tempo de imersão foi de aproximadamente quatro dias para ambas as condições, visto que, as amostras apresentam alto teor de argila.

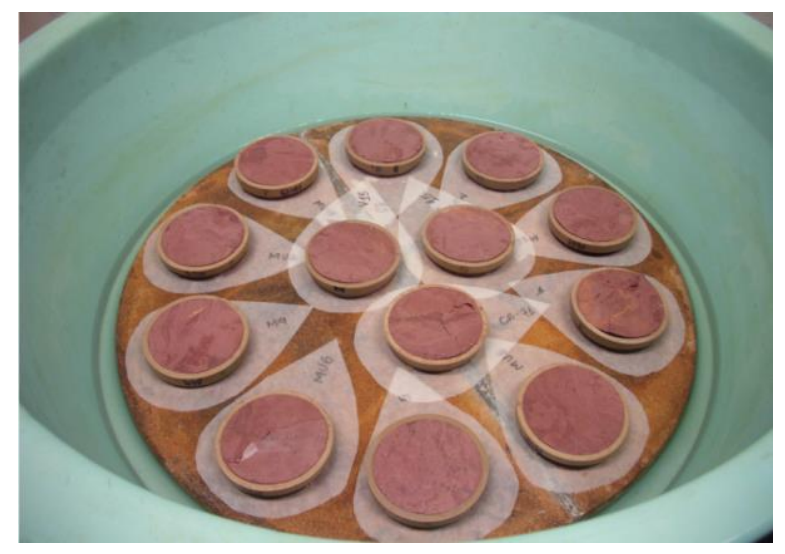

Figura 3.6 - Corpos de prova de amostras indeformadas sobre pedra porosa para saturação.

Após a saturação, os corpos de prova foram deixados em processo de secagem até que atingissem o teor de umidade calculado a partir dos índices físicos para cada ponto da curva de retenção (Figura 3.7a). Os valores de umidade calculados foram obtidos com os pesos dos corpos de prova controlados sucessivamente até a obtenção exata do teor de umidade. Cada ponto representa, então, o comportamento do material na condição saturada até completar a secagem.

Ao atingir o teor de umidade desejado, foram colocados os papéis de filtro Whatman $n^{0} 42$ com diâmetro menor que o dos cilindros em contato direto com a amostra, respectivamente em cada lado (Figura 3.7b). Cada conjunto (papel filtro + amostra + papel filtro) foi cuidadosamente embrulhado com um filme de plástico e envolto com fita adesiva de forma 
firme para garantir o contato entre o papel e a amostra (Figura 3.7c). Em seguida, os conjuntos foram colocados em um isopor hermeticamente fechado por um período de sete dias até que fosse atingido o equilíbrio de umidade entre o papel e o material em sala climatizada com temperatura variando entre $21^{\circ} \mathrm{e} 23^{\circ} \mathrm{C}$.

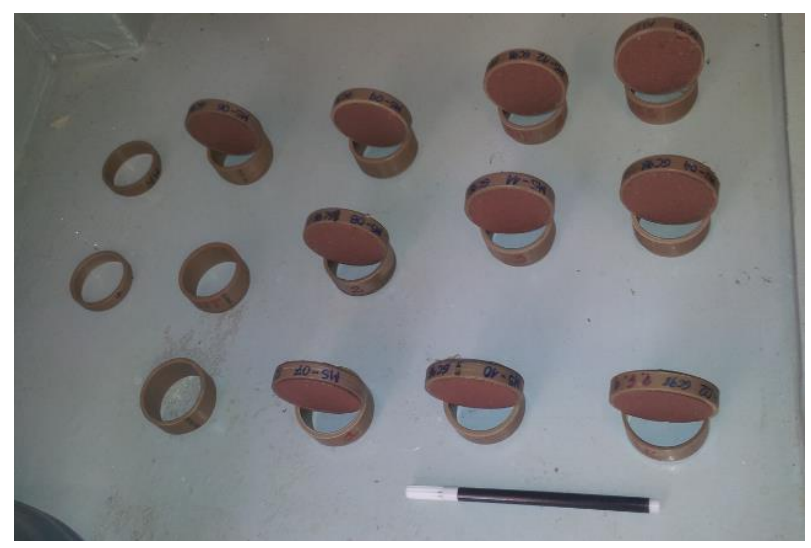

(a)

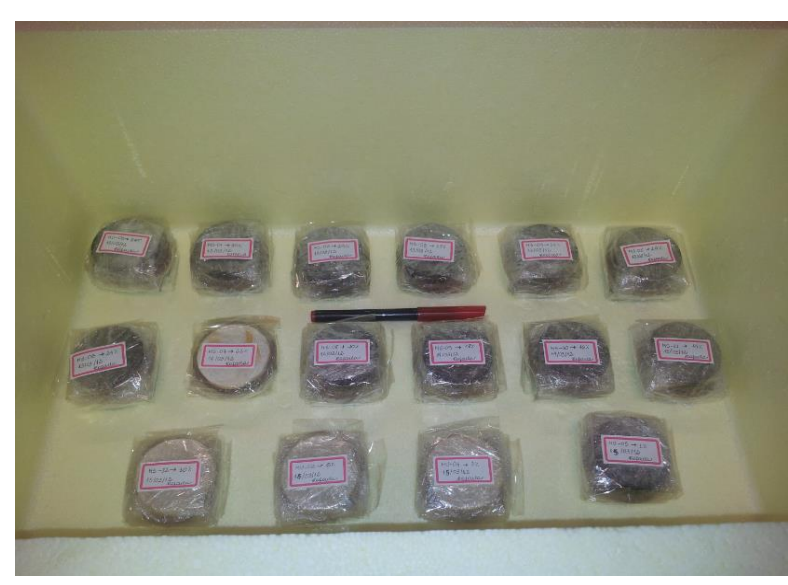

(c)

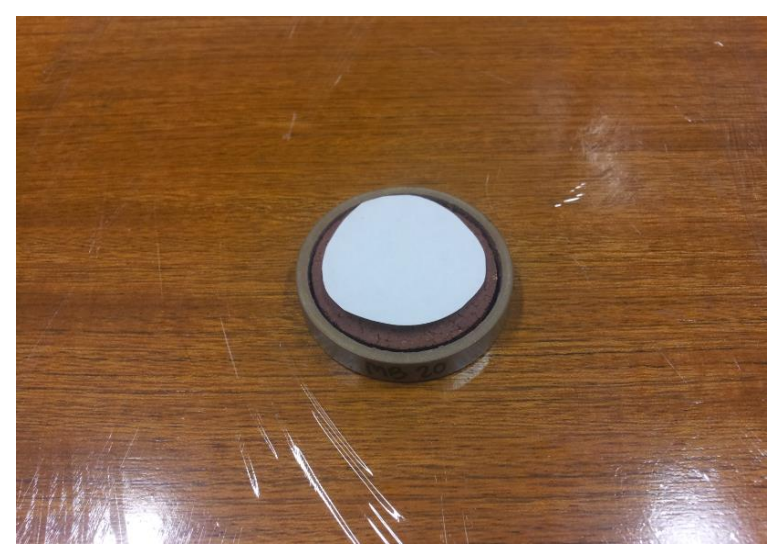

(b)

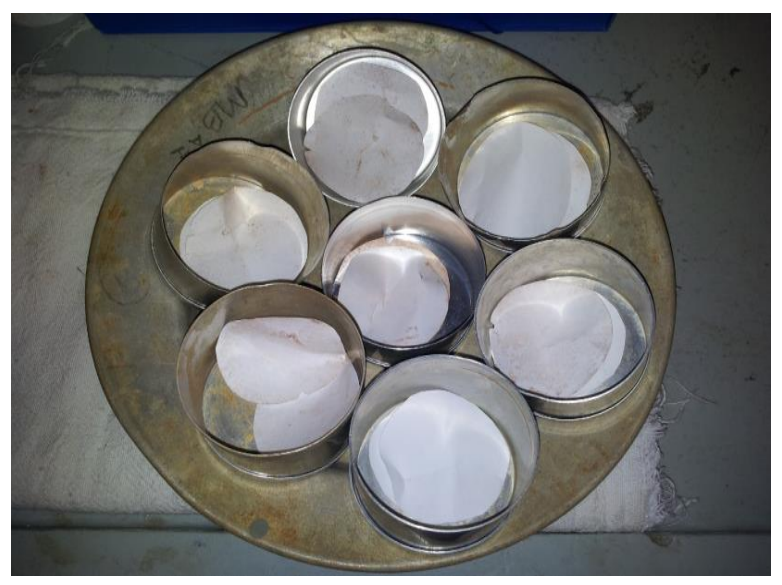

(d)

Figura 3.7 - (a) Corpos de prova em processo de secagem; (b) Montagem do ensaio com papel filtro; (c) Corpos de prova moldados com papel filtro nas umidades calculadas; (d) Papel filtro seco após ensaio.

Após este período, os papéis foram retirados e pesados em uma balança com resolução de 0,0001g. Em seguida, os papéis foram colocados na estufa para secagem (tempo máximo de 4 horas a $110^{\circ} \mathrm{C}$ ) e posteriormente pesados (Figura 3.7d). Determinou-se então, os teores de umidade.

Foram calculadas as umidades de equilíbrio dos papéis e das amostras de solo. A suçãao matricial foi determinada pela umidade dos papéis, por meio das curvas de calibração do papel filtro Whatman $\mathrm{n}^{0} 42$ obtidas por Chandler et al. (1992), expressa pela equação: 
Para umidades do papel filtro > 47\%:

$$
\text { Sucção }(\mathrm{kPa})=10^{(6,05-2,48 \log w)}
$$

Para umidades do papel filtro $\leq 47 \%$ :

$$
\operatorname{Sucção~}(\mathrm{kPa})=10^{(4,84-0,0622 \mathrm{w})}
$$

onde, “w” é a umidade do papel.

- Processo de Umedecimento

Neste processo, os corpos de prova inicialmente moldados nos anéis de PVC foram submetidos à secagem ao ar. Para obtenção da umidade desejada em cada anel, calculou-se previamente o volume de água a ser adicionado no umedecimento das amostras. O controle de umidade foi realizado medindo-se o peso dos corpos de prova considerando a variação pelo umedecimento do solo, uma vez que, a perda de material é inibida durante esse processo (Figura 3.8).

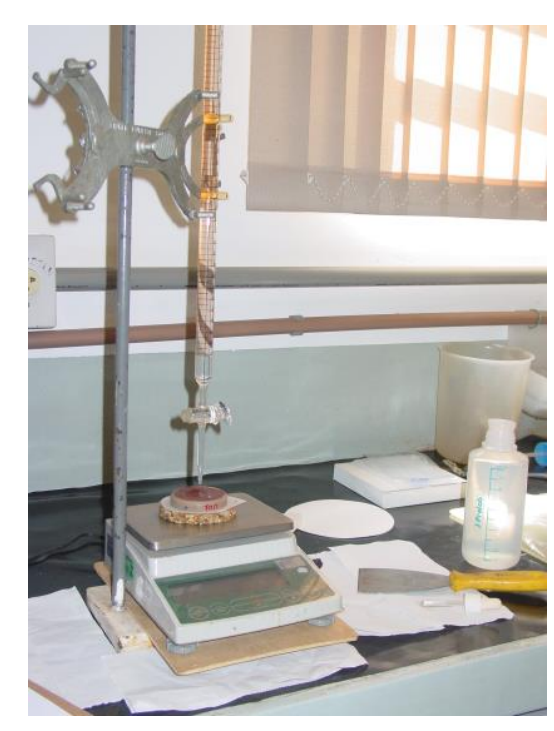

(a)

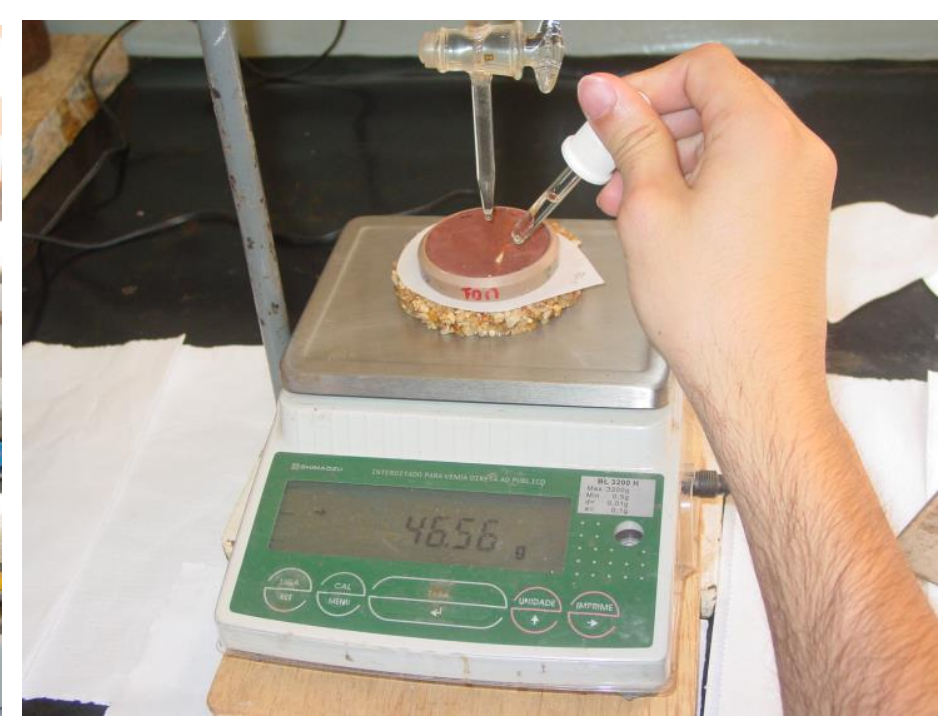

(b)

Figura 3.8 - Processo de umedecimento: (a) Conjunto balança + proveta de umedecimento + amostra; (b) Detalhe de umedecimento e controle do peso da amostra.

Após o umedecimento até a umidade desejada, os anéis foram colcados em sacos plásticos dentro de uma caixa térmica para homogeneização e estabilização da umidade no corpo de prova, como mostra a Figura 3.9. Após 48h, verificou a umidade dos mesmos novamente pelo 
peso, e aqueles que estavam fora do valor foram imediatamente ajustados. Em seguida, foram montados os conjuntos de papel filtro-amostra-papel filtro dando continuidade no ensaio.

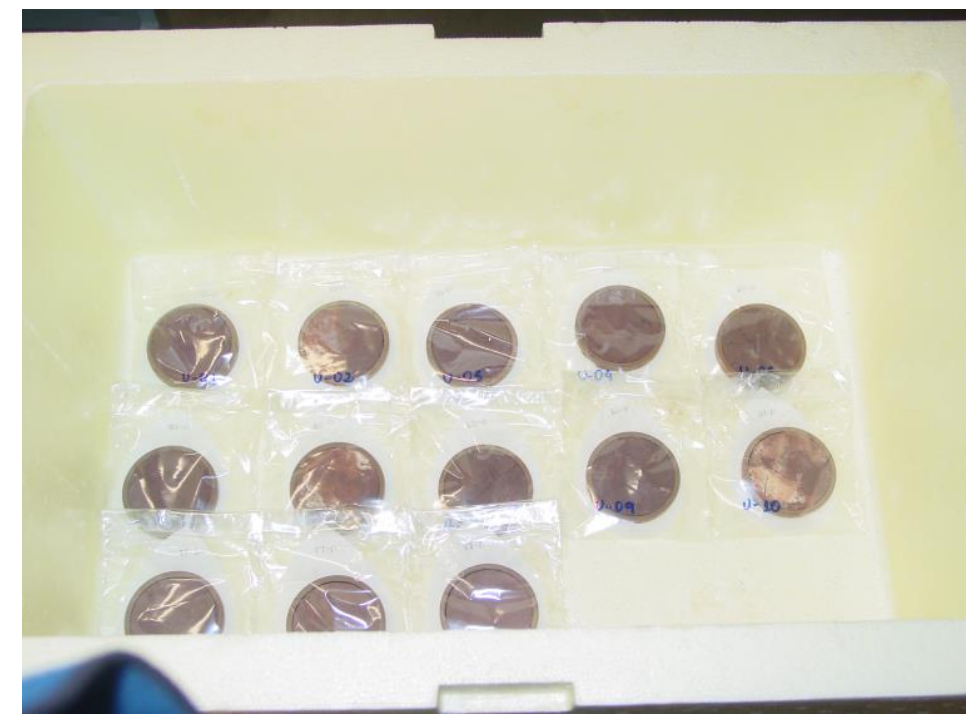

Figura 3.9 - Anéis ensacados na caixa térmica para estabilização da umidade após umedecimento.

\subsubsection{Método do Funil de Placa de Sucção}

Para a determinação dos valores de sucção abaixo de $15 \mathrm{kPa}$, os quais não são possíveis de determinar com o método do papel filtro, utilizou-se o método do Funil de Haynes, comumente conhecido como Funil de Placa de Sucção. O equipamento consiste em um funil com uma placa porosa de alta pressão de entrada de ar, conectada a um tubo flexível acoplado a um reservatório de altura regulável para a saída de água, quando o procedimento é a secagem (Menezes e Pejon, 2010). De acordo com Libardi (2000), a altura máxima da placa porosa em relação ao nível do líquido que permite manter o menisco capilar é de aproximadamente $8,5 \mathrm{~m}$.

O procedimento do ensaio consiste em estabelecer um valor de sucção de acordo com a altura do reservatório posicionado em uma cota inferior ao nível da amostra saturada. A pressão atmosférica atua tanto no solo com no reservatório e, portanto, a diferença de potencial é resultante de uma diferença de cotas (Georgetti, 2010).

$\mathrm{O}$ equipamento permite a aplicação de sucções matriciais entre 1 a $13 \mathrm{kPa}$, as quais correspondem à diferença de cota de 0,1 a 1,3 m (Figura 3.10). Foram ensaiados corpos de prova indeformados e compactados na umidade ótima da Formação Corumbataí com as mesmas dimensões dos corpos de prova ensaiados pela técnica do papel filtro. 


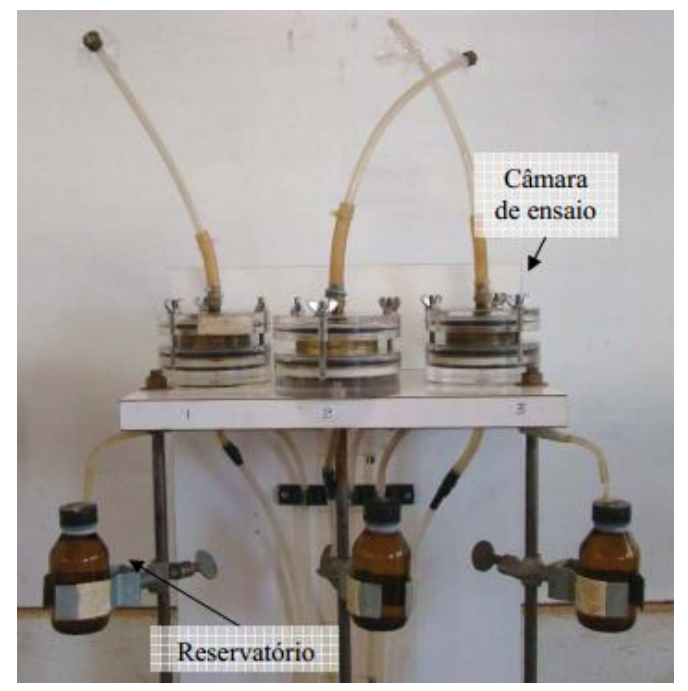

Figura 3.10 - Funil de Placa Porosa (Adaptado de Georgetti, 2010).

O procedimento inicia-se com a saturação do sistema para evitar bolhas de ar no tubo; e saturação prévia dos corpos de prova sobre pedras porosas grossas, revestidas com papel filtro. Em seguida, as amostras foram colocadas sobre as placas porosas já saturadas de 100 $\mathrm{kPa}$ de entrada de ar. O reservatório de água foi posicionado na altura que fornece a sucção desejada. Após essa etapa, inicia-se o ensaio com a abertura da drenagem de água, a fim de permitir a dessaturação da amostra até cessar o fluxo de água. Após o equilíbrio, as amostras foram retiradas do equipamento para pesagem e posterior determinação do teor de umidade gravimétrica.

\subsubsection{Método da Imposição de Umidade Relativa - Dessecador à Vácuo}

Foram determinadas curvas de retenção pelo método do dessecador a vácuo, no qual a sucção é controlada pela imposição de umidade relativa dentro do recipiente, que pode variar de acordo com o tipo e concentração da solução utilizada.

As soluções salinas de $\mathrm{NaCl}$ preparadas em diferentes concentrações de acordo com a Norma ASTM E 104-85 (1991) permitiram impor sucções de 40.000, 25.000, 10.000 e $5.000 \mathrm{kPa}$, para uma temperatura média de $23^{\circ} \mathrm{C}$. Determinou-se a curva de retenção por este método para as amostras indeformada e compactadas na umidade ótima da Formação Corumbataí.

Após a moldagem dos materiais em anéis de PVC similares aos utilizados no ensaio de papel filtro, as amostras foram colocadas dentro do dessecador. Cada dessecador continha uma dada concentração da solução salina de $\mathrm{NaCl}$. As amostras foram mantidas dentro dos recipientes até atingir o equilíbrio de umidade, que foi controlado por sucessivas pesagens dos anéis com o material até que não houvesse variação significativa no peso (Figura 3.11 e Figura 3.12). 


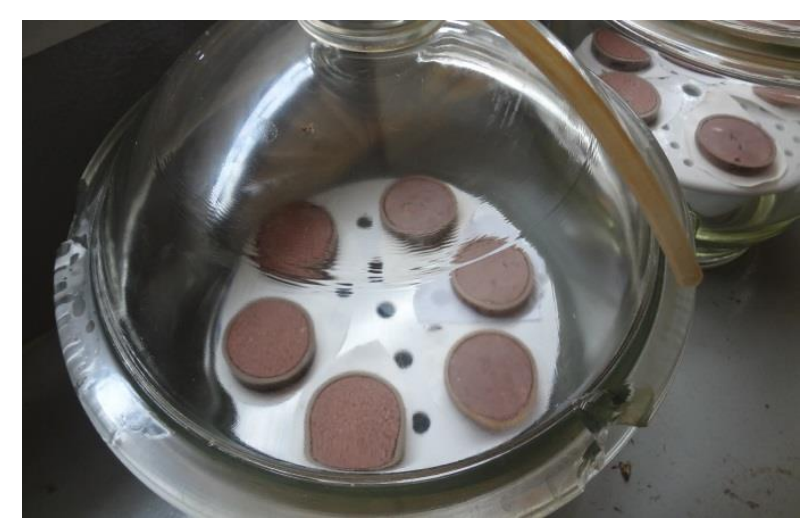

(a)

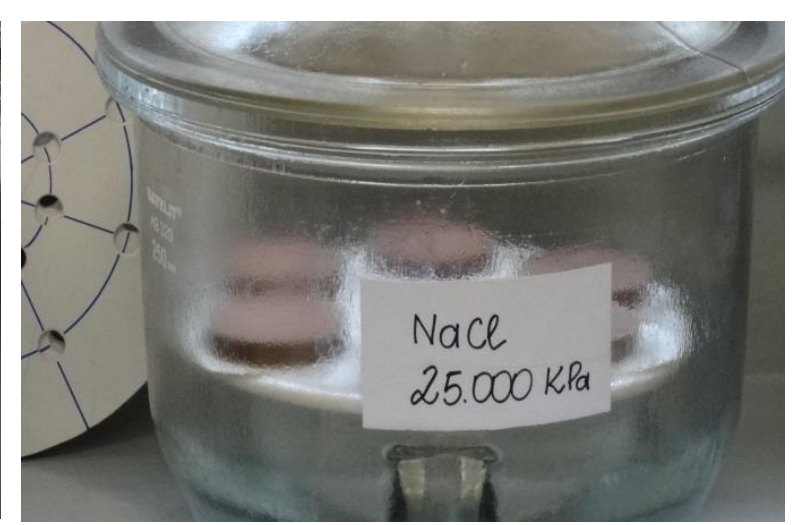

(b)

Figura 3.11 - Detalhes das amostras dentro dos dessecadores de vidro.

Após sucessivas pesagens, ao atingir o equilíbrio, considerou-se que toda transferência de água em forma de vapor já havia cessado. À cada pesagem, aplicou-se uma pressão de vácuo de $40 \mathrm{kPa}$ em cada dessecador para acelerar o processo de transferência de vapor de água, visto que, este ensaio foi de longa duração com mais de 9 meses para estabilização das umidades. Durante o ensaio, controlou-se a temperatura de forma rigorosa dentro do ambiente da sala de ensaio. Os resultados permitiram determinar pares de umidade gravimétrica (\%) versus Sucção Total $(\mathrm{kPa})$.

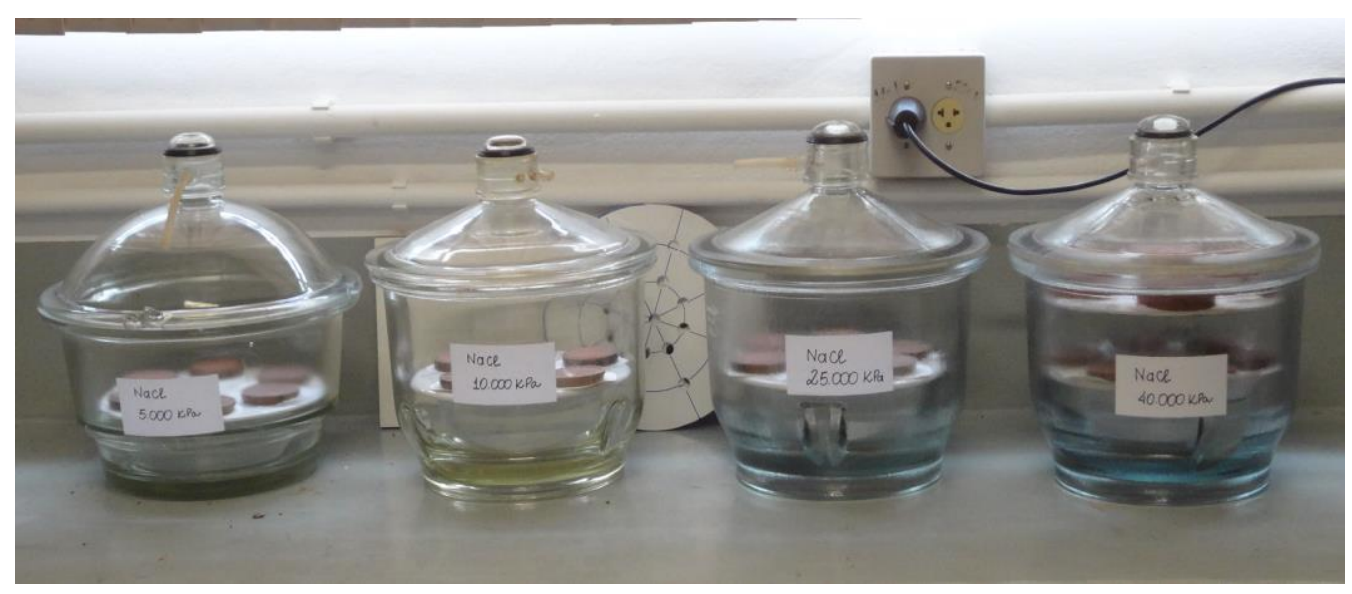

Figura 3.12 - Corpos de prova nos dessecadores à vácuo.

$\sqrt{ }$ Calibração do Papel Filtro

A calibração do papel filtro foi realizada apenas para determinar a sucção do mesmo em condições conhecidas, como por exemplo, em soluções salinas em diferentes concentrações (Figura 3.13). Para esse ensaio, seguiu-se o mesmo procedimento descrito para o dessecador a vácuo, com o controle da umidade dos papéis através da pesagem dos mesmos em uma balança com resolução de $0,0001 \mathrm{~g}$. 
Após atingir o equilíbrio de vapor em cada sucção, pesaram-se os papéis, e em seguida, colocaram-se na estufa por um período de 4 horas. Após secagem em estufa, os papéis foram pesados novamente para a determinação do teor de umidade correspondente a cada sucção imposta.

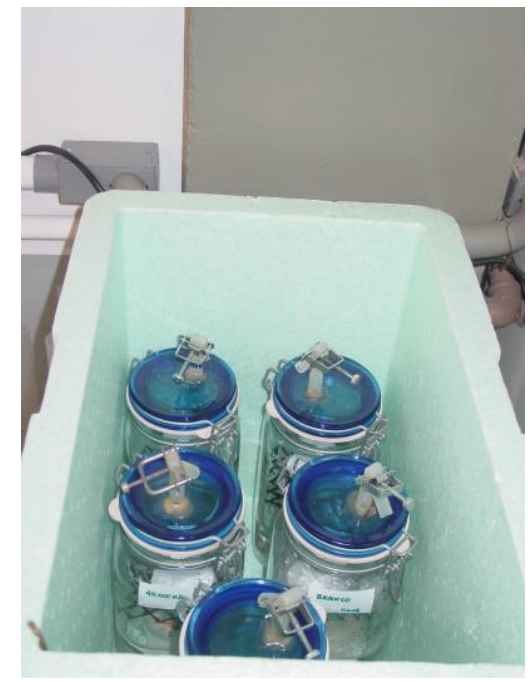

(a)

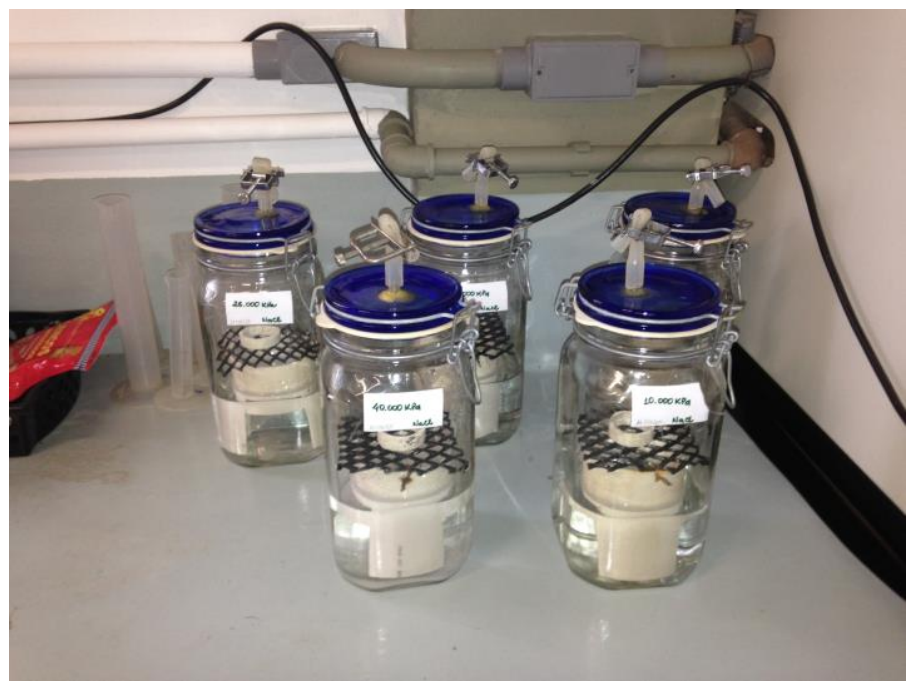

(b)

Figura 3.13 - Dessecadores para calibração dos papéis de filtro.

\subsubsection{Preparação dos Corpos de Prova para Ensaios de Expansão}

\subsubsection{Corpos de Prova Indeformados}

Os corpos de prova indeformados foram moldados, inicialmente à mão, de forma cuidadosa diretamente dos blocos indeformados para evitar a quebra ou fissura do material. Após estabilização das umidades desejadas para as sucções iniciais, os CP's foram remoldados em um torno mecânico para acertar o diâmetro e faces superiores e inferiores (Figura 3.14). 

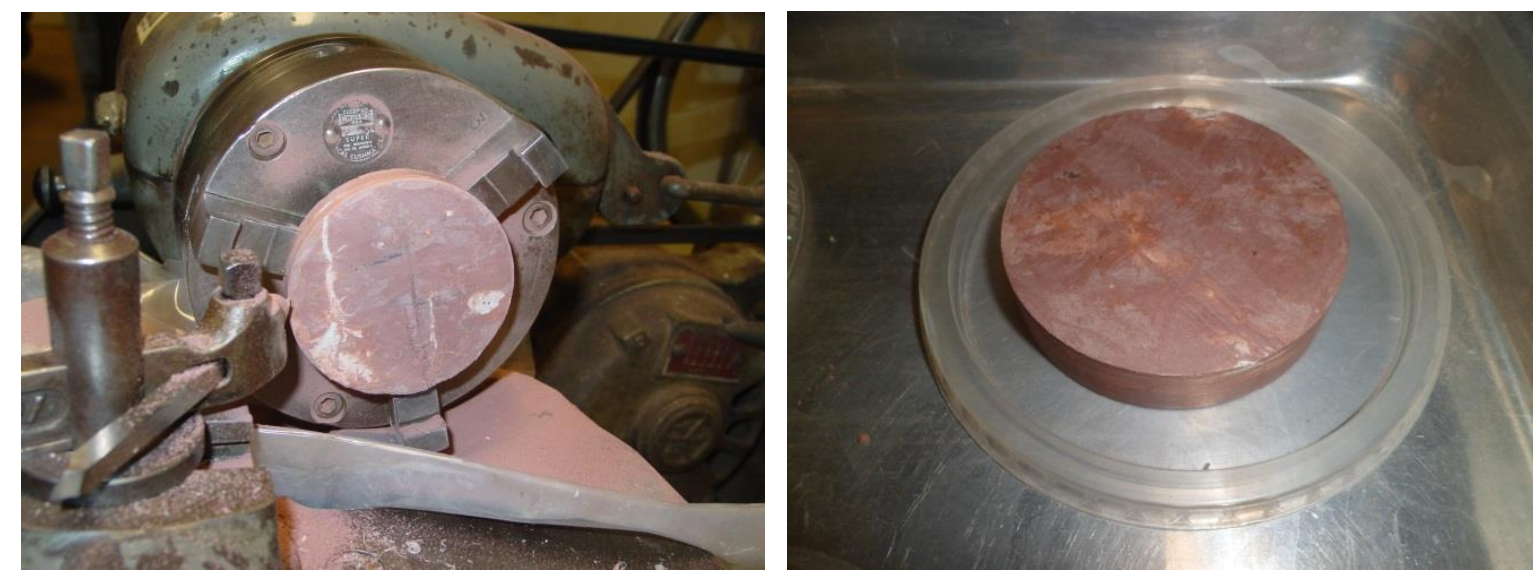

Figura 3.14 - Detalhes da remoldagem dos corpos de prova indeformados: (a) amostra no torno mecânico; (b) Detalhe do corpo de prova após remoldagem.

\subsubsection{Corpos de Prova Compactados}

Os corpos de provas foram moldados imediatamente antes da montagem da célula edométrica para assegurar o total controle da umidade inicial do material ensaiado. A compactação dos corpos de prova foi realizada por meio de uma prensa manual que permitiu a obtenção de diferentes densidades secas (Figura 3.15). Essa preparação foi adotada para os corpos de prova ensaiados tanto na expansão inundada, como na transferência de vapor.

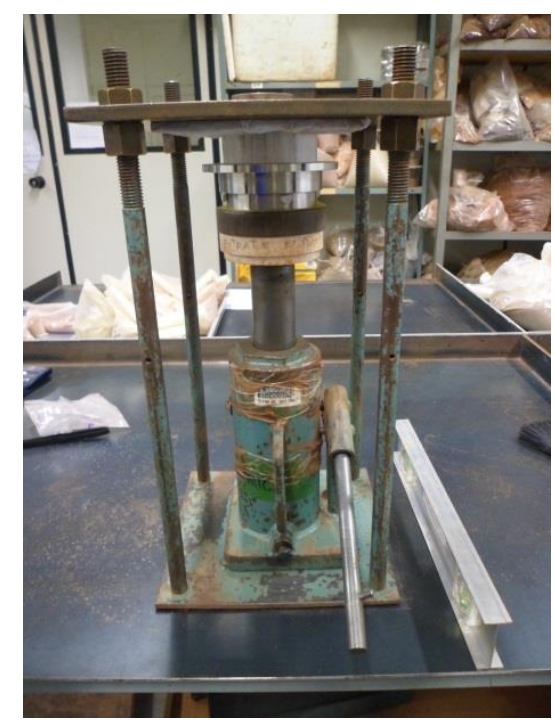

Figura 3.15 - Prensa para compactação dos corpos de prova.

Na Figura 3.15 é possível observar que as amostras foram compactadas diretamente no anel de inox da célula edométrica. Maiores detalhes da montagem na prensa de compactação, e do corpo de prova compactado podem ser vistos na Figura 3.16. 


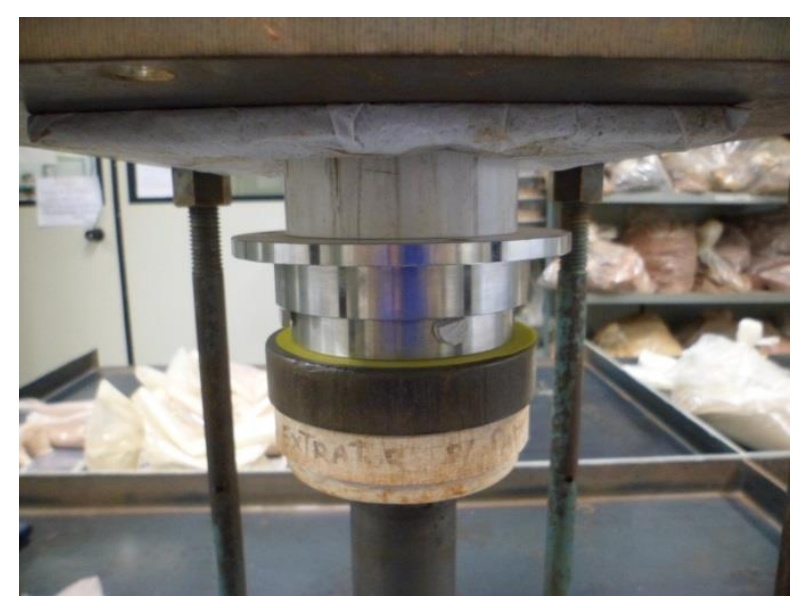

(a)

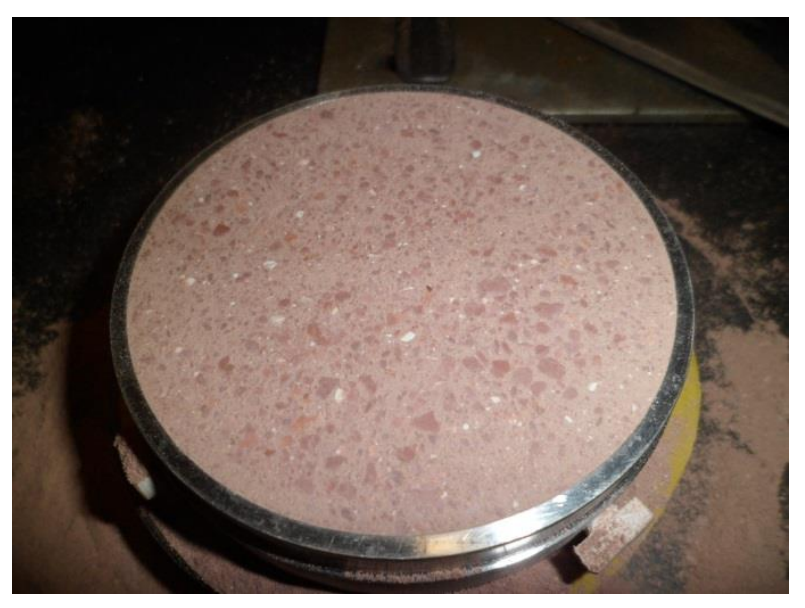

(b)

Figura 3.16 - Detalhes da preparação dos corpos de prova: (a) Montagem na prensa de compactação; (b) Corpo de prova compactado.

\subsubsection{Liofilização das Amostras Antes e Após Expansão Inundada}

As amostras submetidas à expansão inundada foram liofilizadas antes e após os ensaios. Para a condição antes do ensaio, foram moldados dois corpos de prova idênticos, e colocados na mesma condição que antecedeu o ensaio de expansão (dessecadores para estabilização da umidade inicial e secagem ao ar). Já na condição após o ensaio de expansão, tomou-se como amostra a ser liofilizada o próprio corpo de prova ensaiado. Essas amostras foram liofilizadas para manter a microestrutura do material nas situações de antes e após a expansão a fim de analisar os poros e a estrutura interna.

A liofilização é uma técnica de secagem que constitui na remoção da água por meio do processo de sublimação. O material é, inicialmente, congelado, ou seja, todo o seu conteúdo de água transforma-se em gelo, e em seguida é submetido a condições de pressões muito baixas (Marques, 2008).

O congelamento do material foi realizado, previamente, com um banho de nitrogênio, onde as amostras foram colocadas em um Becker e inseridas em um recipiente com nitrogênio (Figura 3.17). Após essa etapa, o material doi colocado no equipamento, o qual é composto de uma câmara hermeticamente fechada que permite remover o ar de dentro através de uma bomba de alto vácuo, criando uma condição para que ocorra a sublimação da água. 


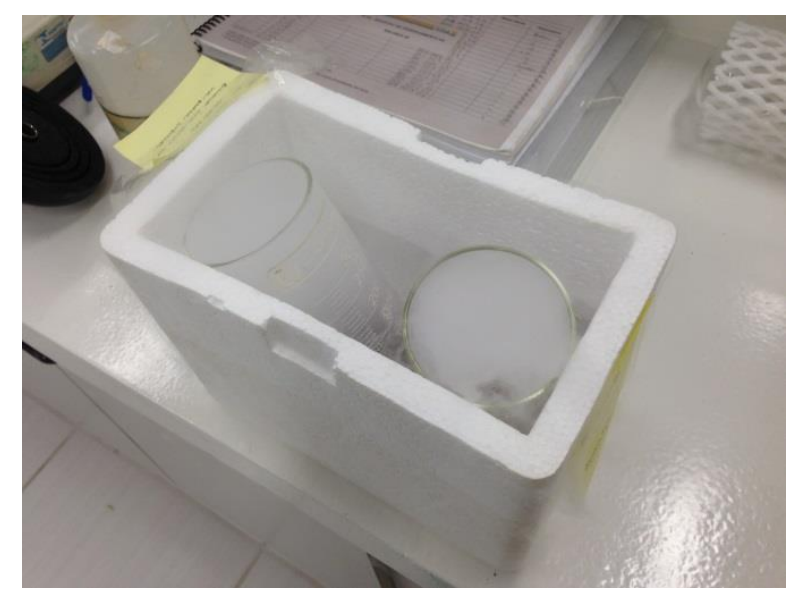

Figura 3.17 - Congelamento prévio com nitrogênio.

Este processo de liofilização foi realizado no Laboratório de Química Orgânica do Instituto de Quimica de São Carlos (IQSC) da Universidade de São Paulo no liofilizador de bancada da marca Edwards, modelo L 202 (Figura 3.18).

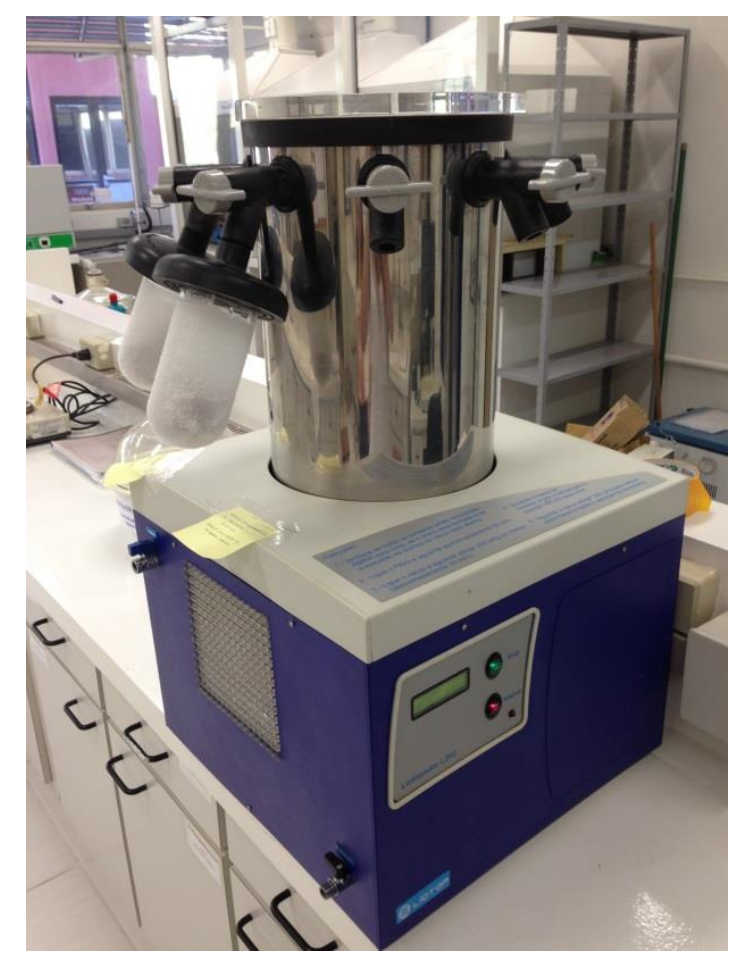

Figura 3.18 - Equipamento de liofilização de amostras. 


\subsubsection{Pressão de Expansão por Inundação}

\subsubsection{Método à Volume Constante em Edômetro Convencional}

Nesta fase da pesquisa, o potencial expansivo das amostras foi avaliado por meio de ensaios de pressão de expansão pelo método a volume constante, sem o controle de sucção, preconizado pela Associação Internacional de Mecânica das Rochas (ISRM, 1989).

Foram ensaiadas amostras nas condições indeformadas e compactadas, totalizando 20 ensaios de expansão inundada, cujas moldagens estão descritas a seguir:

(1) Cinco corpos de prova indeformados moldados com material da Formação Corumbataí diretamente dos blocos, com diâmetro aproximado de 7,3 cm e altura 2,0 cm. Em seguida, as amostras foram colocadas em dessecadores a vácuo para atingir a umidade correspondente à sucção inicial desejada. Os corpos de prova foram testados nas condições: seco ao ar; sucções inicial estabilizadas em 40.000, 25.000, 10.000 e $5.000 \mathrm{kPa}$.

(2) Cinco corpos de prova com material da Formação Corumbataí compactados na umidade ótima, e em seguida colocados em dessecadores a vácuo para atingir a umidade correspondente à sucção inicial desejada. As amostras foram testadas nas condições: seco ao ar; sucções inicial estabilizada em 40.000, 25.000, 10.000 e $5.000 \mathrm{kPa}$.

(3) Um corpo de prova com material da Formação Corumbataí compactado na condição seca ao ar (pó);

(4) Cinco corpos de prova compactados com material seco ao ar (pó) da Formação Corumbataí misturados com bentonita, nas seguintes porcentagens: com 70\%, 50\%, 30\%, $10 \%$, e $5 \%$ de bentonita.

(5) Um corpo de prova de bentonita pura compactada na condição seca ao ar (pó);

(5) Três corpos de prova compactados com material seco ao ar (pó) da Formação Botucatu misturados com bentonita, nas seguintes porcentagens: com $70 \%, 50 \%$, e $30 \%$.

As sucções iniciais pré-estabelecidas aos corpos de prova indeformados e compactados da Formação Corumbataí descritos nos itens (1) e (2) foram impostas a partir de soluções salinas de cloreto de sódio $(\mathrm{NaCl})$ preparas em diferentes concentrações, de acordo com a norma ASTM E 104-85 (1991). 
O ensaio de expansão pelo método a volume constante consiste em confinar uma amostra em uma célula edométrica. Inicialmente, aplica-se uma pré-carga equivalente a $25 \mathrm{kPa}$ para ajustar o sistema, e anota-se o valor referente ao "zero" nos deflectômetros. Nos ensaios realizados nesta pesquisa a pressão de ajuste aplicada foi de $35 \mathrm{kPa}$, pois o sistema de aquisição de dados não apresentou resolução para registros menores de pressão. Em seguida, preenche-se com água destilada o reservatório até o nível da placa porosa superior à amostra, a fim de inundar o sistema. Registra-se, então, a força e o deslocamento axial em função do tempo. O aumento no carregamento é realizado a cada deslocamento vertical de $0,01 \mathrm{~mm}$ $(0,05 \%)$ até que a altura do corpo de prova retorne para o valor inicial, ou seja, carrega-se até que o deflectômetro volte para o "zero".

O ensaio deve ser continuado até que não haja mais deslocamento axial, ou seja, até mobilizar completamente a expansão da amostra. A pressão máxima de expansão corresponde à pressão final na mobilização da expansão. Os dados do ensaio são apresentados em gráficos de Pressão de Expansão (kPa) versus Tempo (h).

Para a realização desses ensaios, foi desenvolvido um equipamento compatível com sistema sugerido pela ISRM (1989) que consiste em cinco prensas edométricas, a fim de avaliar a pressão de expansão com o maior controle na aplicação dos carregamentos, e também nas medidas de deslocamento axial. Dessas cinco prensas, apenas uma foi utilizada para expansão inundada, e as demais para o ensaio com transferência de vapor.

\subsubsection{Desenvolvimento do Equipamento - Expansão Inundada}

O equipamento consiste em um conjunto de prensa manual com célula edométrica e uma célula de carga.

\section{$\sqrt{ }$ Célula Edométrica}

(a) Anel de aço inoxidável rígido para acomodar a amostra, com borda interna lisa e polida (Figura 3.19[1]). A espessura da parede do anel tem $0,85 \mathrm{~cm}$ e altura de 2,0 cm. Esse anel deve apresentar um encaixe na parte superior onde será colocada uma espécie de "colar" de aço inoxidável com mesmo diâmetro (Figura 3.19[2]). O colar é a peça que será presa por três parafusos na base da célula edométrica, garantindo assim, a fixação do conjunto. Utiliza-se também um anel-braçadeira para acomodar a amostra no anel, visto que, devido secagem ao ar ocorre uma variação no diâmetro da amostra de solo. 


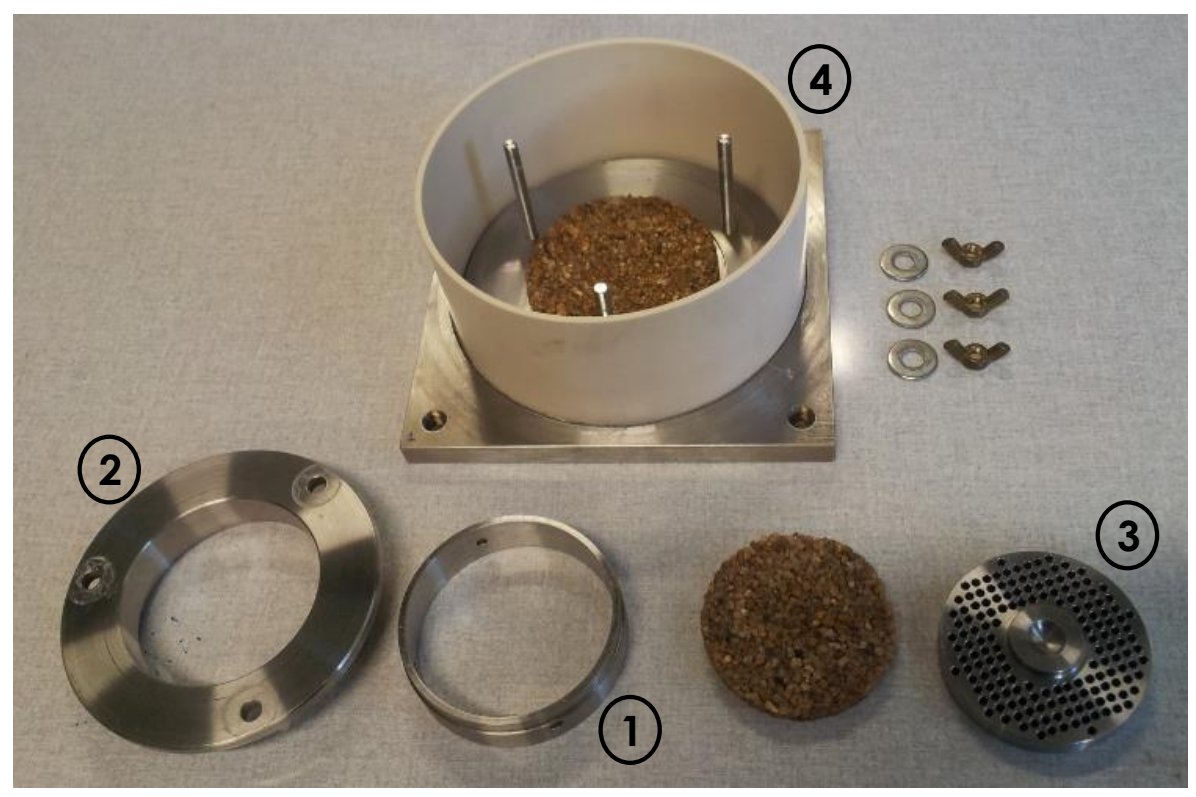

Figura 3.19 - Peças para montagem da célula edométrica para ensaio com inundação.

(b) Placa crivada de aço inoxidável com uma concavidade no centro para acomodar o pistão de carregamento (Figura 3.19[3]). Essa concavidade tem a função de uma rótula. Os furos da placa crivada devem apresentar diâmetros aproximados de $1 \mathrm{~mm}$ a fim de garantir o abastecimento de água no interior do anel onde será colocada a amostra. A placa crivada deve ser suficientemente espessa para assegurar a aplicação do carregamento (dimensões - altura $1,0 \mathrm{~cm}$, e diâmetro $6,1 \mathrm{~cm})$.

(c) Duas placas porosas confeccionadas com material granular. A placa superior deve apresentar um diâmetro $5 \mathrm{~mm}$ menor que o diâmetro da amostra de solo, e a placa inferior deve ser do tamanho do anel de inox apenas para encaixar na base da célula edométrica.

(d) Na base da célula edométrica foi colado um tubo de PVC com cola adesiva para servir de reservatório.

A Figura 3.20 apresenta o esquema de montagem do corpo de prova na célula edométrica. A Figura 3.20a mostra o corpo de prova com um anel cilíndrico de abertura flexível. Foi utilizado esse anel móvel para envolver a lateral da amostra, visto que, após secagem, os corpos de prova apresentaram diâmetro menor. Portanto, para garantir a perfeita fixação e encaixe no cilindro da célula edométrica, fez-se necessário a utilização deste anel. O corpo de prova com o anel flexível é colocado no cilindro e ajustado por meio de quatro parafusos na lateral (Figura 3.20b). O colar de fixação é encaixado no conjunto anel + anel flexível + corpo de prova (Figura 3.20c). Na base da célula edométrica é colocada uma placa porosa (Figura 3.20e), e posteriormente o conjunto é fixado na base de inox por meio de três parafusos (Figura 3.20f). 


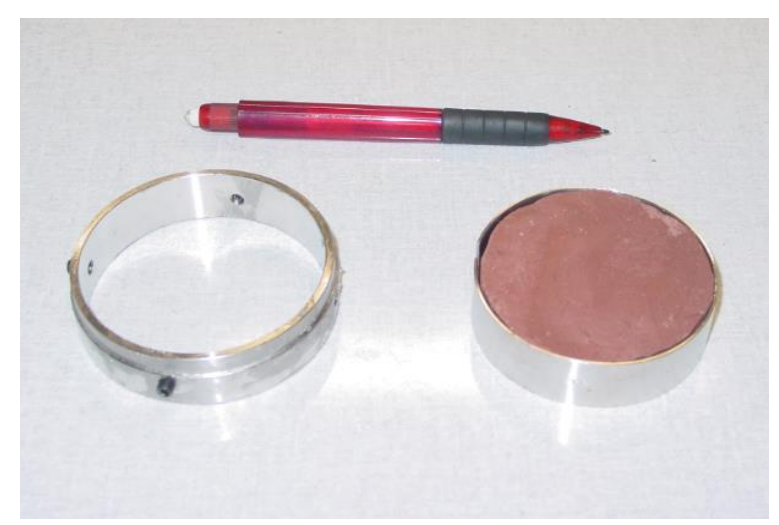

(a)

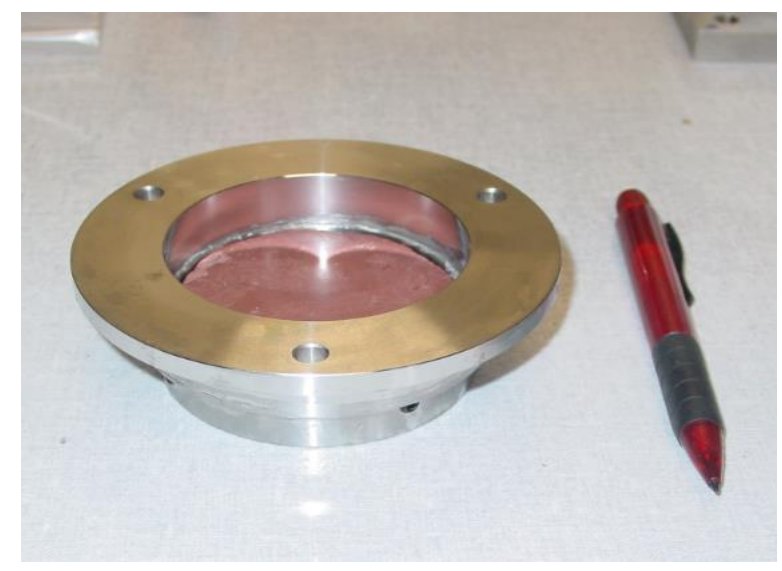

(c)

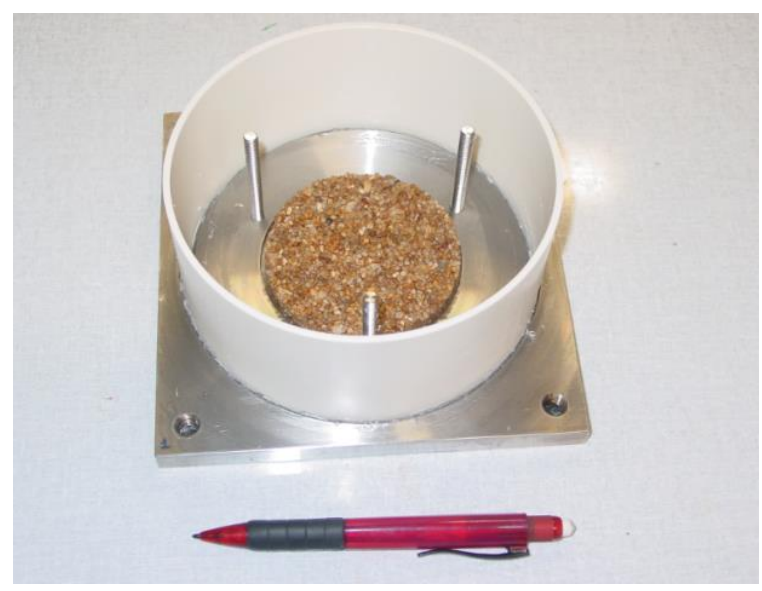

(e)

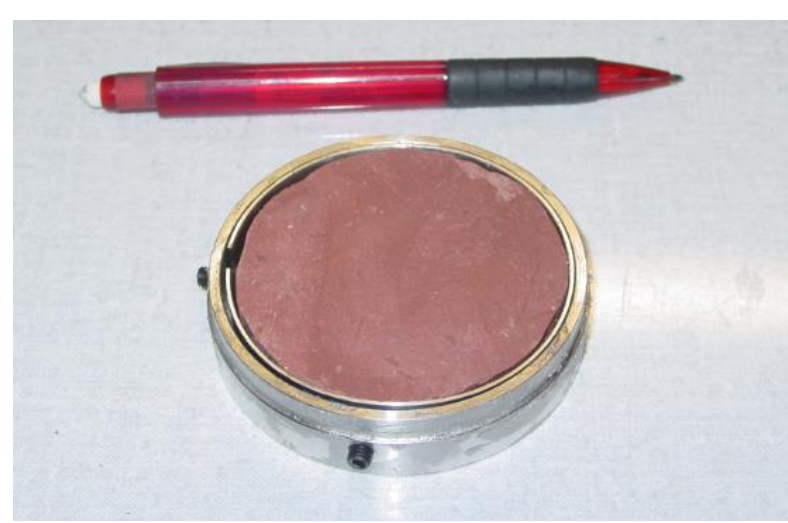

(b)

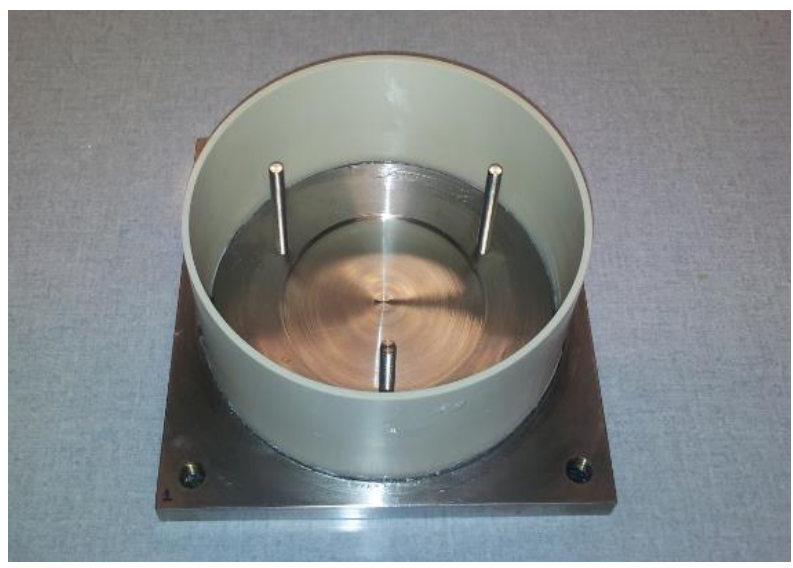

(d)

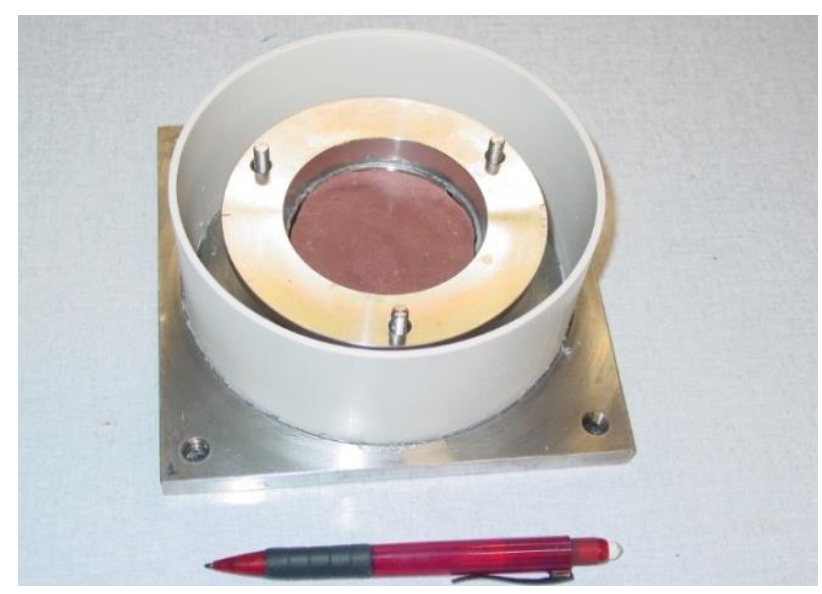

(f)

Figura 3.20 - Esquema de montagem das peças da célula edométrica: (a) Corpo de prova na braçadeira; (b) Anel + abraçadeira; (c) Conjunto de anel + abraçadeira + corpo de prova + colar; (d) Base com reservatório; (e) Base + pedra porosa inferior; (f) Conjunto de anel + abraçadeira + corpo de prova + colar montados na base da célula edométrica.

\section{$\sqrt{ }$ Prensa}

O projeto da prensa manual foi desenvolvido com base no método sugerido pela ISRM (1989). Foram realizados ensaios teste para verificar a funcionalidade do sistema. Durante os 
testes detectaram-se perdas de sensibilidade nas medições dos deslocamentos devido à posição dos deflectômetros. Após inúmeras tentativas de reposicionamento dos sensores, foram realizadas modificações no arranjo final, o que assegurou a redução de movimentos indesejados no sistema. A Figura 3.21 apresenta as modificações realizadas no arranjo preconizado pela ISRM (1989).

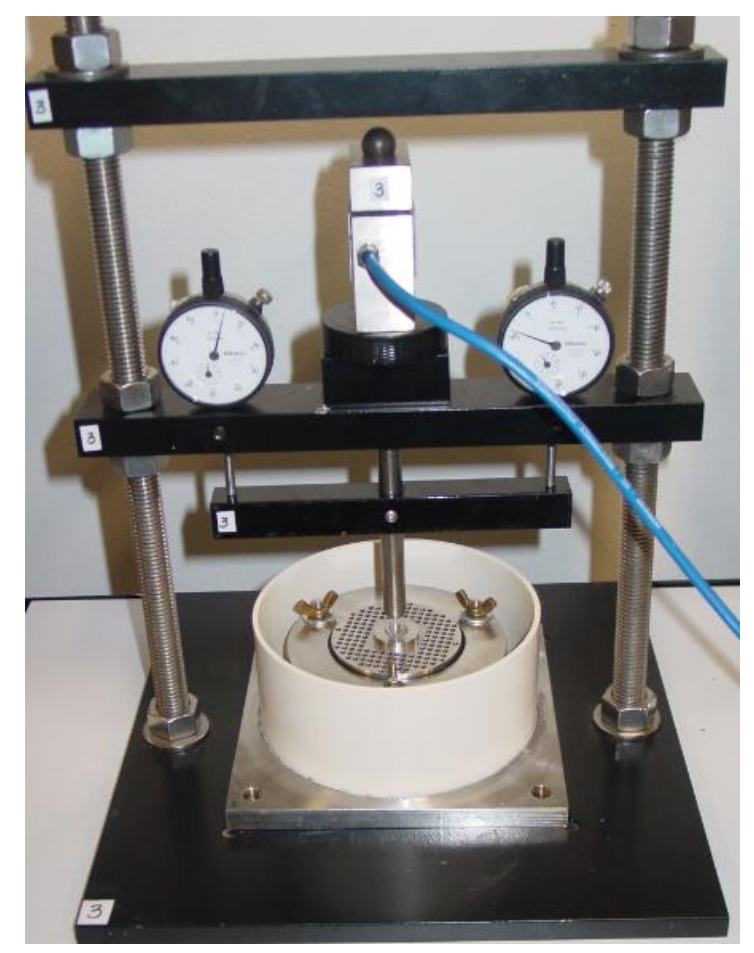

(a)

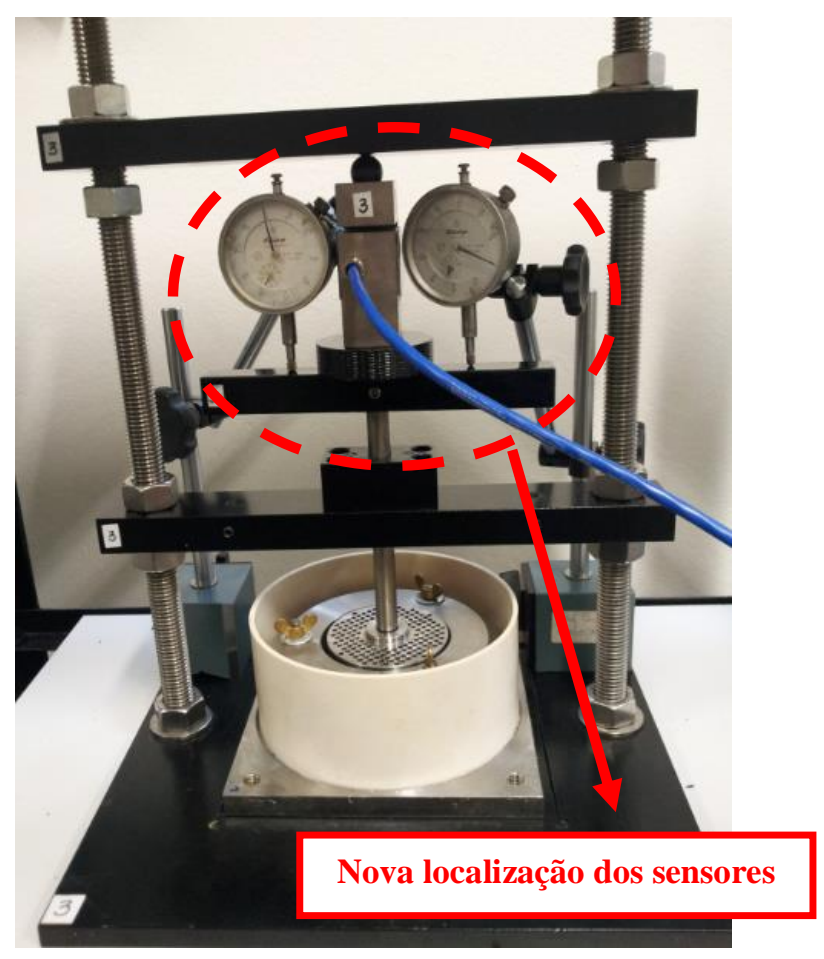

(b)

Figura 3.21 - (a) Prensa com arranjo montado segundo ISRM (1989); (b) Prensa com arranjo modificado nesta pesquisa.

Na Figura 3.21 é possível observar que a mudança no arranjo da prensa se deu na localização das ponteiras dos deflectômetros. No arranjo antigo (Figura 3.21a) os sensores posicionavamse na barra fixa roscada nos parafusos. O arranjo modificado (Figura 3.21b) prevê nova localização, sendo a fixação dos mesmos situados na barra menor fixa ao pistão de carregamento, acima da barra fixa aos parafusos. Esta nova localização dos sensores permitiu aproximar ao máximo os deflectômetros do conjunto pistão + célula de carga, o que garantiu menor perda de sensibilidade das leituras de deslocamento.

A Figura 3.22 apresenta o projeto final da prensa após as modificações com as respectivas medidas das peças que compõem o sistema. 


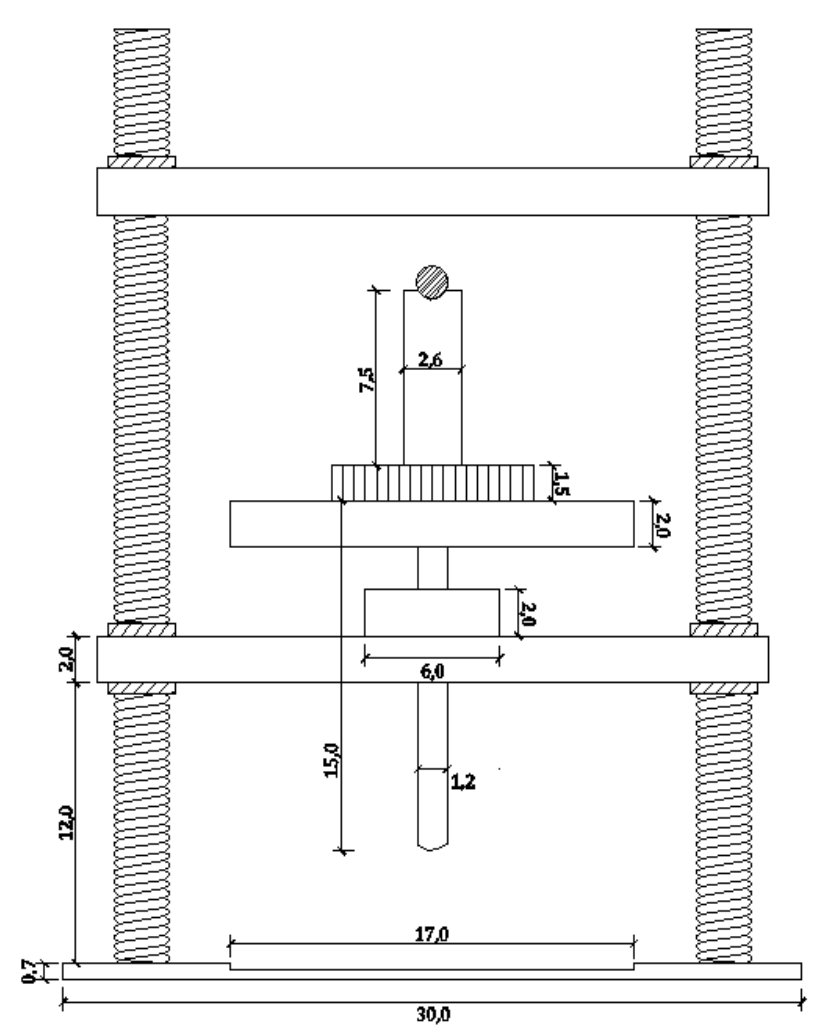

Figura 3.22 - Projeto modificado da prensa para ensaio de pressão de expansão (medidas em centímetro).

\subsubsection{Componentes do Sistema de Aplicação de Carga}

O sistema de aplicação de carga é composto de vários elementos descritos a seguir:

(a) Dois parafusos rígidos capazes de aplicar carga por meio de roscas e arruelas em conjunto com uma barra de aço fixos á uma base com dimensões de 30,0 x 30,0 cm. Os parafusos apresentam diâmetro de $1,8 \mathrm{~cm}$ e devem estar em perfeito estado de conservação (livre de corrosão) para garantir o ajuste contínuo do carregamento mantendo a altura da amostra a um valor constante. A base na qual os parafusos são afixados deve apresentar um rebaixo para encaixar a célula edométrica e evitar qualquer movimento indesejado do sistema.

(b) Pistão de carregamento, ou haste, com extremidade hemisférica, para assentar sobre a placa crivada de carregamento. O pistão deve ter o diâmetro de $1,2 \mathrm{~cm}$ e altura de $15,0 \mathrm{~cm}$, soldado a um disco de aço na parte superior com rosca no topo para fixar a célula de carga. Ao longo do comprimento do pistão, uma barra menor é fixa para apoiar o cursor dos deflectômetros que medirão o deslocamento do pistão. O pistão passa por um orifício existente em uma barra fixa no sistema que garante a verticalidade no momento do carregamento. 
(c) Dois deflectômetros com sensibilidade de $0,01 \mathrm{~mm}$ com base magnética são apoiados sobre a barra menor fixa no pistão apenas para medir o deslocamento (Figura 3.23).

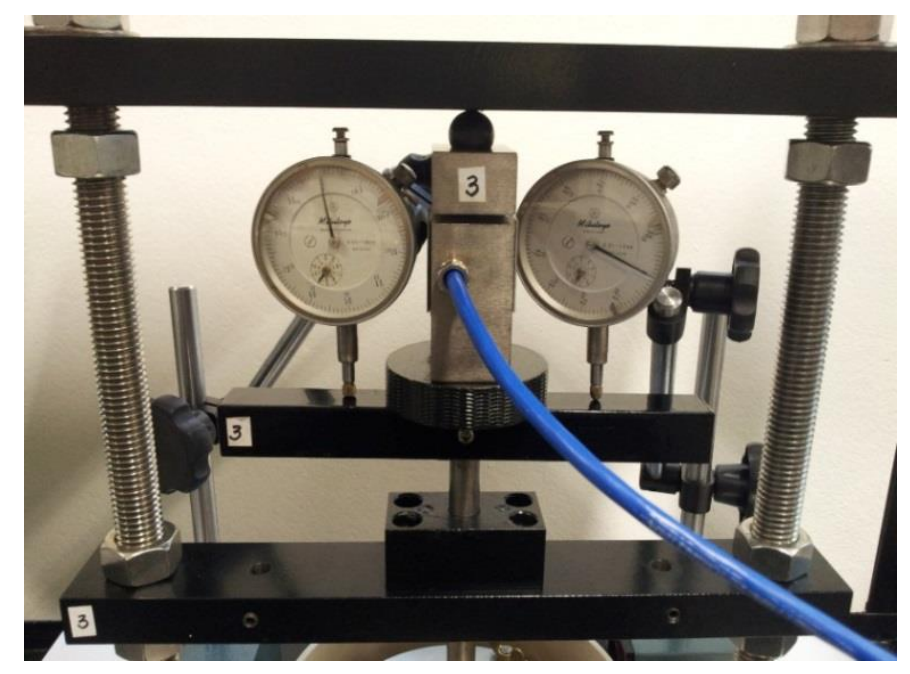

Figura 3.23 - Novo posicionamento dos deflectômetros na prensa.

(d) Célula de Carga

Para medir o carregamento foram utilizadas células de carga da marca Reaccion, modelo CZC-1000 (Figura 3.24). A célula de carga possui capacidade para $1 \mathrm{tf}$. O dispositivo é fixo na rosca existente no topo do pistão. A alimentação das células de carga foi realizada por uma fonte de 10 Vcc da marca Minipa. A calibração das células de carga foi realizada de forma estática na prensa de expansão utilizando-se uma célula de carga aferida de mesma capacidade com sistema de aquisição de dados P3 da Vishay Micro Measurement.

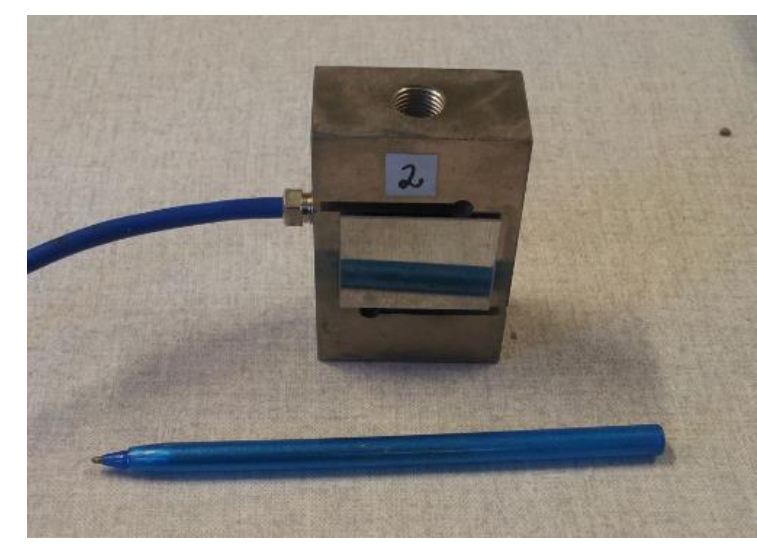

Figura 3.24 - Célula de carga utilizada nos ensaios de pressão de expansão. 
(e) Sistema de Aquisição de Dados

Os registros de carregamentos da célula de carga foram realizados por um sistema de aquisição analógica da marca NOVUS, “Registrador FieldLogger". Este equipamento registra os dados e armazena as informações em uma memória interna. Possui 64 canais de entrada e uma entrada para alimentação.

Os dados registrados pelo FieldLogger foram transmitidos ao computador através de um conversor USB-i485 da NOVUS. A comunicação e tratamento dos dados foi realizada pelo software FieldChart da NOVUS. 


\subsubsection{Pressão de Expansão por Transferência de Vapor}

\subsubsection{Método à Volume Constante em Edômetro com Sucção Controlada}

A pressão de expansão dos materiais desta pesquisa foi analisada, também, pela variação de volume pelo controle de sucção por imposição de umidade relativa. Para este ensaio, utilizouse um equipamento similar ao utilizado na expansão por inundação, porém com algumas adaptações e modificações na célula edométrica.

A técnica da imposição de umidade relativa consiste em impor níveis de sucção total à amostra por meio da pressão parcial de vapor de água que se encontra em equilíbrio com a água do solo. Ou seja, a umidade relativa conhecida pela concentração da solução salina permite saber qual a sucção que está sendo imposta ao sistema.

Os ensaios foram realizados em amostras secas ao ar, posteriomente compactadas em diferentes condições, por processo de umedecimento. Foram ensaiadas, ainda, amostras indeformadas e, também, amostras compactadas na umidade ótima e posteriormente secas ao ar. No geral, foram ensaiados 15 corpos de provas, em que 5 não apresentaram pressão de expansão, e 10 revelaram pressão de expansão. A Tabela 3.1 apresenta o conjunto de amostras ensaiadas com esta técnica:

Tabela 3.1 - Amostras ensaiadas com a técnica da transferência de vapor.

\begin{tabular}{|c|c|}
\hline \multicolumn{2}{|l|}{ AMOSTRAS } \\
\hline Material Argiloso da Formação Corumbataí & Terminologia \\
\hline Amostra Indeformada & - \\
\hline Amostra compactada na Wót e depois seca ao ar, ensaiada sem bomba de circulação & - \\
\hline Amostra compactada na Wót e depois seca ao ar, ensaiada com bomba de circulação & - \\
\hline Amostra compactada na Wót e depois seca ao ar, ensaiada com bomba e circulação na pedra inferior & - \\
\hline Amostra compactada na Wót e depois seca ao ar, ensaiada na prensa de adensamento & - \\
\hline Misturas Argilosas da Formação Corumbataí com Bentonita & Terminologia \\
\hline Bentonita pura seca compactada & Bentonita \\
\hline Amostra argilosa seca compactada com $70 \%$ de bentonita & Argiloso $+70 \%$ \\
\hline Amostra argilosa seca compactada com $50 \%$ de bentonita & Argiloso $+50 \%$ \\
\hline Amostra argilosa seca compactada com $30 \%$ de bentonita & Argiloso $+30 \%$ \\
\hline Amostra argilosa seca compactada com $10 \%$ de bentonita & Argiloso $+10 \%$ \\
\hline Amostra argilosa seca compactada com 5\% de bentonita & Argiloso $+5 \%$ \\
\hline Amostra argilosa seca compactada & Argiloso \\
\hline Misturas Arenosas da Formação Botucatu com Bentonita & Terminologia \\
\hline Amostra arenosa seca compactada com $70 \%$ de bentonita & Arenoso $+70 \%$ \\
\hline Amostra arenosa seca compactada com $50 \%$ de bentonita & Arenoso $+50 \%$ \\
\hline Amostra arenosa seca compactada com $30 \%$ de bentonita & Arenoso $+30 \%$ \\
\hline
\end{tabular}

Nos ensaios, foram impostas sucções de $5.000 \mathrm{kPa}$ por meio de solução salina de $\mathrm{NaCl}$ preparada segundo as recomendações da Norma ASTM E 104-85 (1991). As pressões de 
expansão foram medidas por meio de um sistema de aquisição de dados acoplado a uma célula de carga localizada imediatamente acima do pistão de carregamento.

A metodologia de ensaio foi a mesma utilizada na expansão inundada a volume constante, como descrito no item 3.2.4.4. A diferença principal está no tempo duração do ensaio, que não é de 24 h. O tempo desse ensaio é função da mobilização total da expansão para o nível de sucção imposto pela solução salina. Ou seja, considera-se que, uma vez cessada a expansão, o corpo de prova já sofreu sua expansão máxima sob níveis de sucções desejados. Esse tempo de ensaio pode durar meses, e dependendo do tipo de material até anos.

\subsubsection{Desenvolvimento do Equipamento - Transferência de Vapor}

Para a realização dos ensaios com a transferência de vapor foi desenvolvido um sistema fechado que permite a circulação do vapor de água do reservatório de solução salina até a célula edométrica. Com esse sistema de reservatório externo é possível trocar a concentração da solução para impor diferentes níveis de sucção sem comprometer o confinamento do corpo de prova na célula edométrica. É possível, também, utilizar uma bomba de circulação de vapor para acelerar o processo de umedecimento do corpo de prova, uma vez que, essa forma de transferência de umidade é demorada.

A Figura 3.25 mostra uma visão geral da prensa de expansão com o sistema de transferência de vapor desenvolvido nesta pesquisa. A seguir, é descrita separadamente a construção das peças que compõem o equipamento, a montagem do ensaio, bem como, o sistema de aquisição de dados.

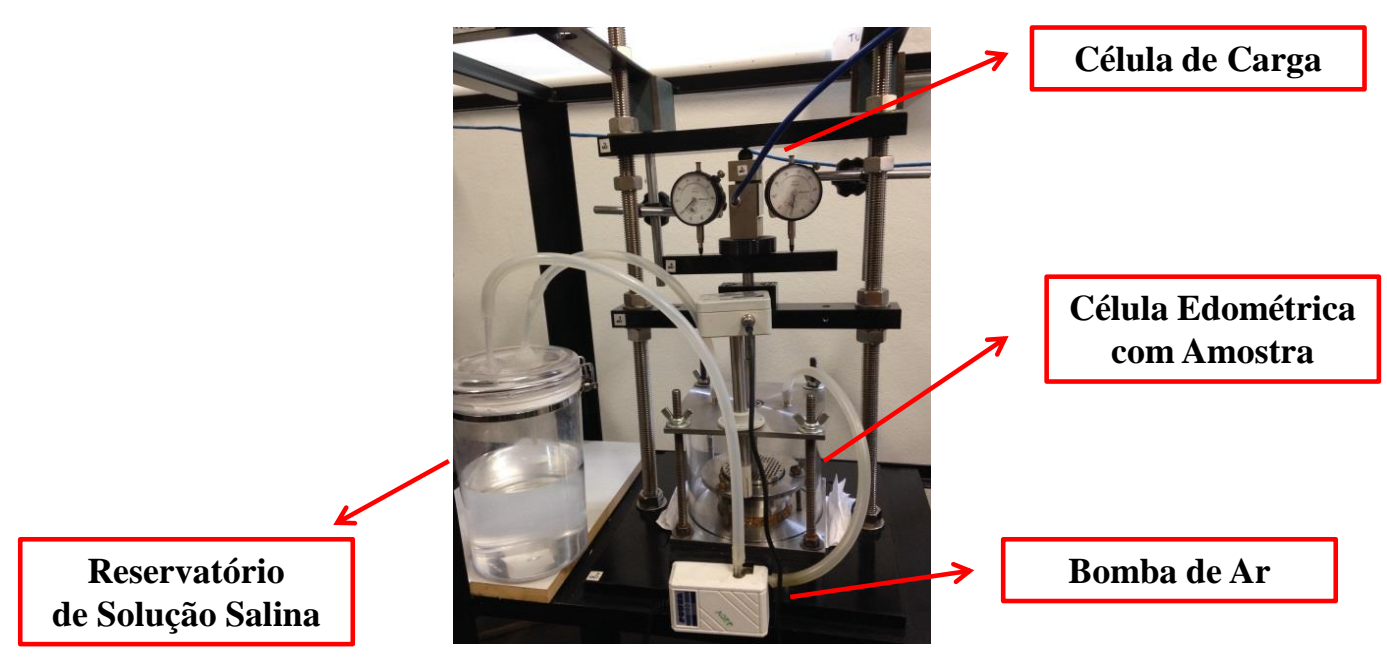

Figura 3.25 - Equipamento para medir pressão de expansão por transferência de vapor. 


\section{$\sqrt{ }$ Célula Edométrica}

Na Figura 3.26, as peças [1], [2], [3] e [4] são montadas da mesma forma como descrito no ensaio de expansão inundada. A diferença está no cilindro de acrílico (Figura 3.25[6]) para o fechamento da célula com a colocação da tampa (Figura 3.26 [7]).

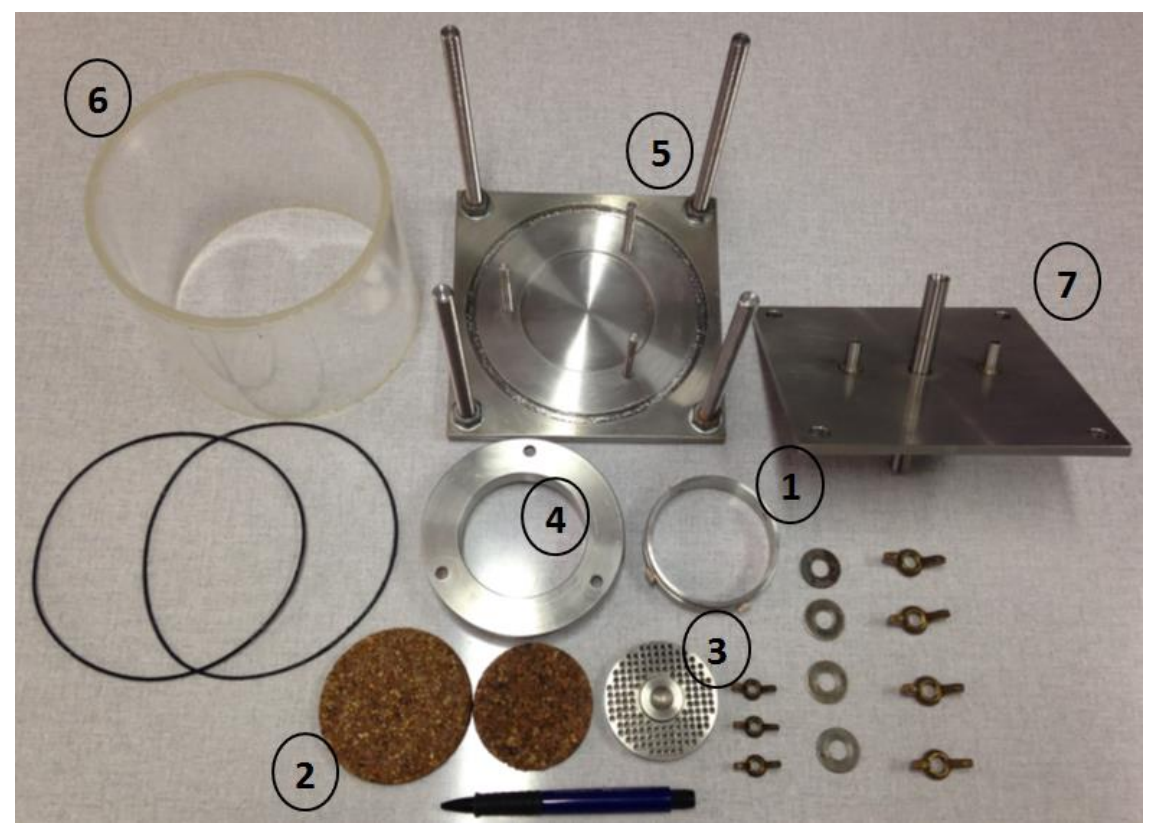

Figura 3.26 - Peças de montagem da célula edométrica para ensaio com a técnica da transferência de vapor.

A Figura 3.27 apresenta as fases de montagem da célula edométrica: em [a] coloca-se a pedra porosa de alta permeabilidade na base da célula; em [b] ilustra-se a colocação do anel onde é moldado o corpo de prova; acima do corpo de prova, em [c] é colocado o colar de aço para assegurar que o anel com o corpo de prova esteja fixo na pedra porosa inferior; na parte superior do anel com o corpo de prova [d], coloca-se uma pedra porosa identica à inferior, e logo acima a placa crivada que será o apoio do pistão de carregamento. Para garantir que o sistema esteja hermeticamente fechado, aplica-se graxa de silicone na depressão de encaixe do cilindro de acrílico, evitando, assim, possíveis vazamentos. Em [e] indica-se a colocação do cilindro de acrílico com os o-rings na parte inferior e superior. Por fim, em [f] é mostrada a célula montada com tampa e base inferior.

Vale ressaltar que a Figura 3.27 é ilustrativa, apenas para mostrar o passo a passo da montagem da célula edométrica. No momento da montagem, o corpo de prova é compactado diretamente no anel de aço, imediatamente antes do ensaio. 


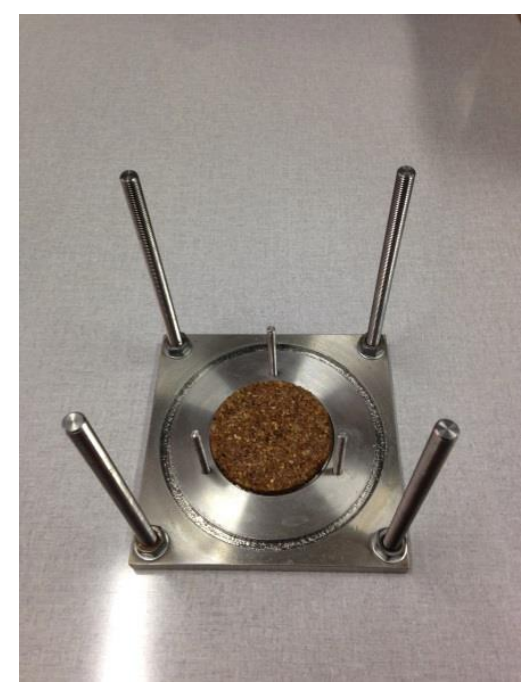

(a)

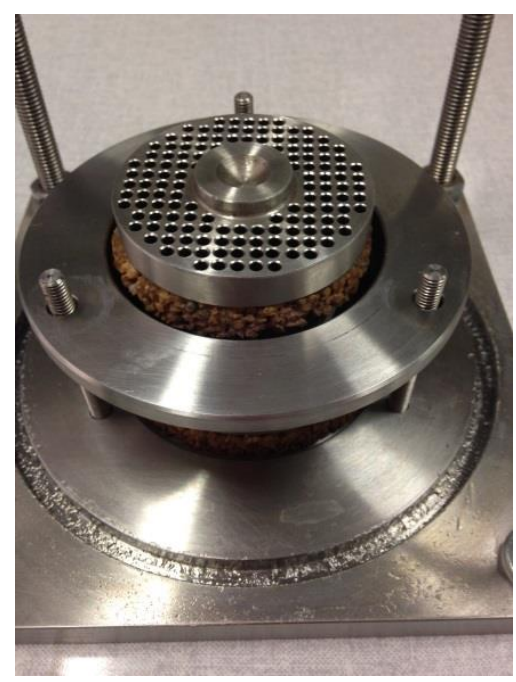

(d)

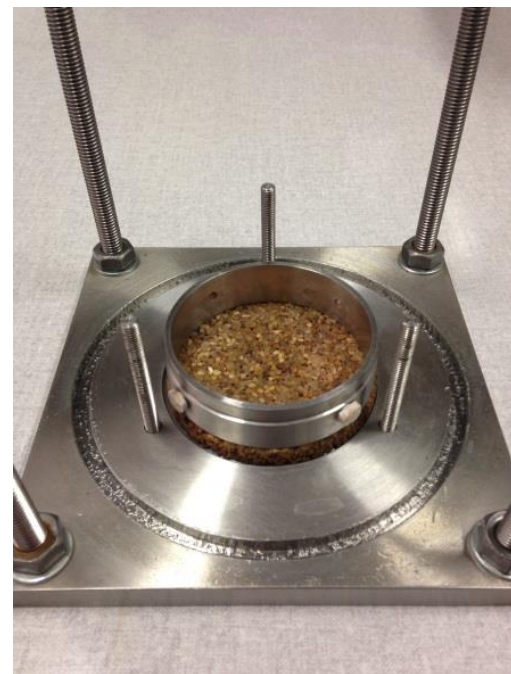

(b)

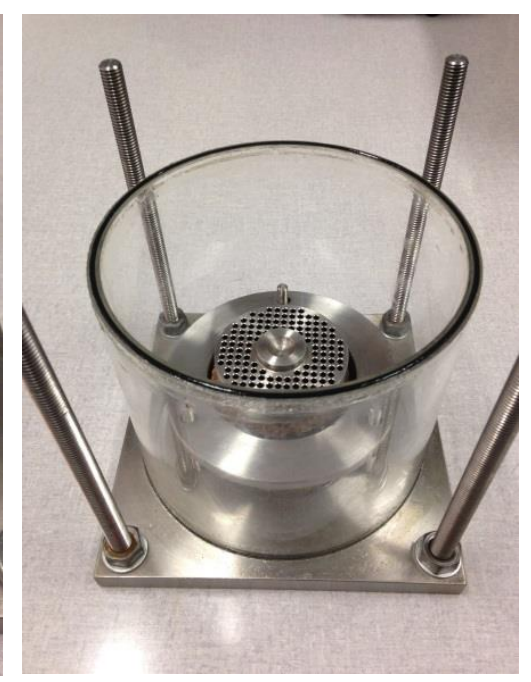

(e)

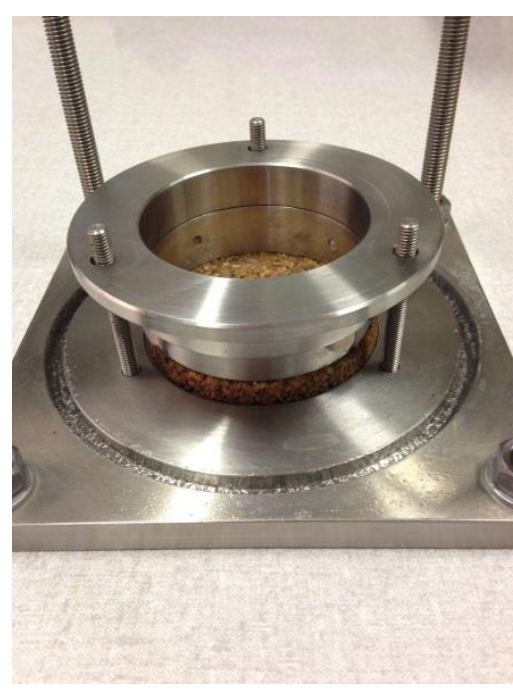

(c)

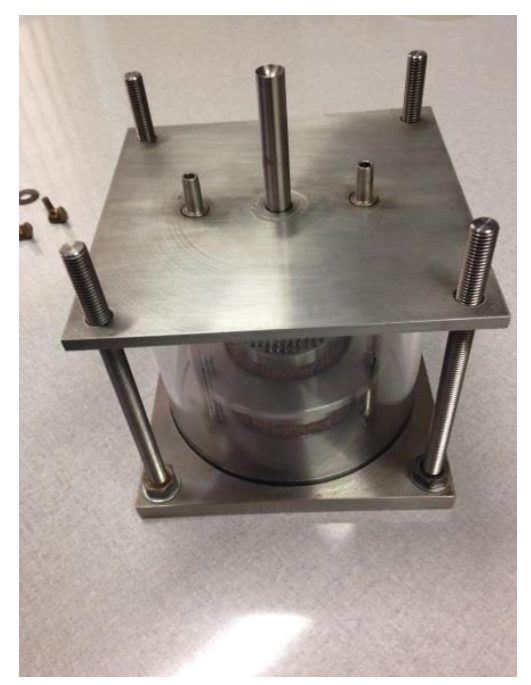

(f)

Figura 3.27 - Montagem da célula edométrica: (a) Pedra porosa inferior; (b) Anel portaamostra acima da pedra porosa; (c) Colar de fixação do anel porta-amostra; (d) Pedra porosa superior + placa crivada; (e) Cilidro de acrílico; e (f) Tampa de célula edométrica.

$\sqrt{ }$ Reservatório de Solução Salina

O reservatório para armazenar a solução salina foi confeccionado a partir de um pote de acrílico com tampa hermética, o qual garantiu o não vazamento do vapor para o ambiente externo. A Figura 3.28 mostra o reservatório com as adaptações para colocação das mangueiras que ligam com a bomba de circulação e a célula edométrica. 


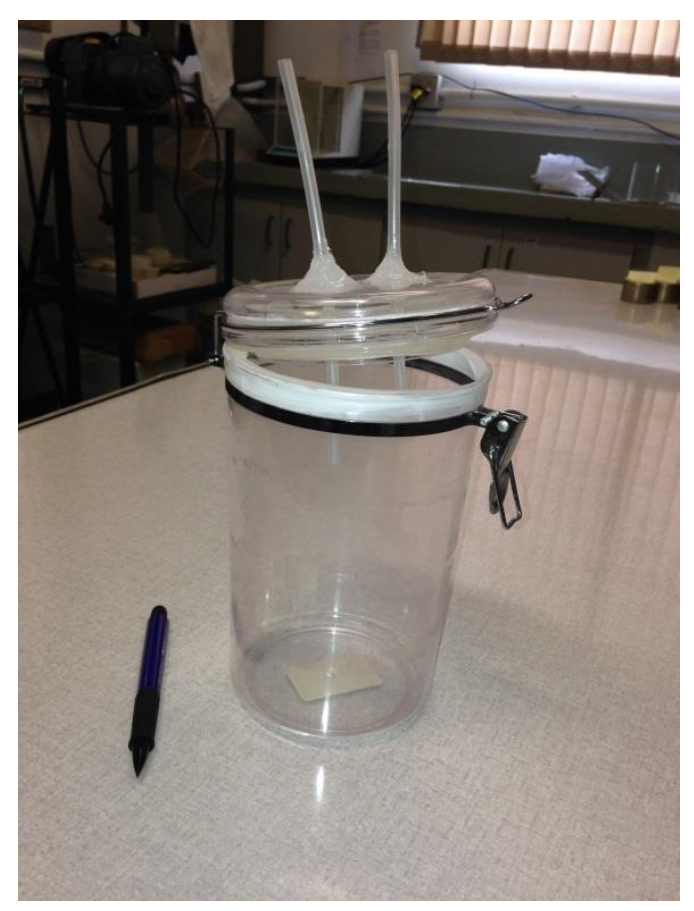

Figura 3.28 - Reservatório de armazenamento para solução salina.

Na Figura 3.29 é possível abservar alguns cuidados que foram tomados a cada montagem do reservatório com solução. Na tampa, foram feitos dois furos para colagem de dois canos flexíveis para entrada e saída de vapor de água. Esses canos foram colados com silicone, e neles foram encaixadas as mangueiras responsáveis pelo fluxo do vapor. Para evitar vazamentos, foi aplicada fita branca de vedação em toda a extremidade do reservatório para assegurar o encaixe perfeito da tampa.

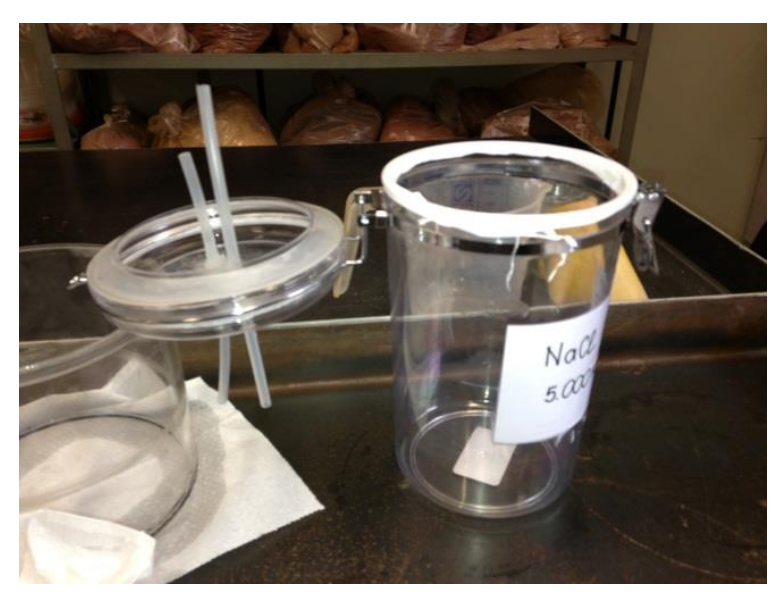

(a)

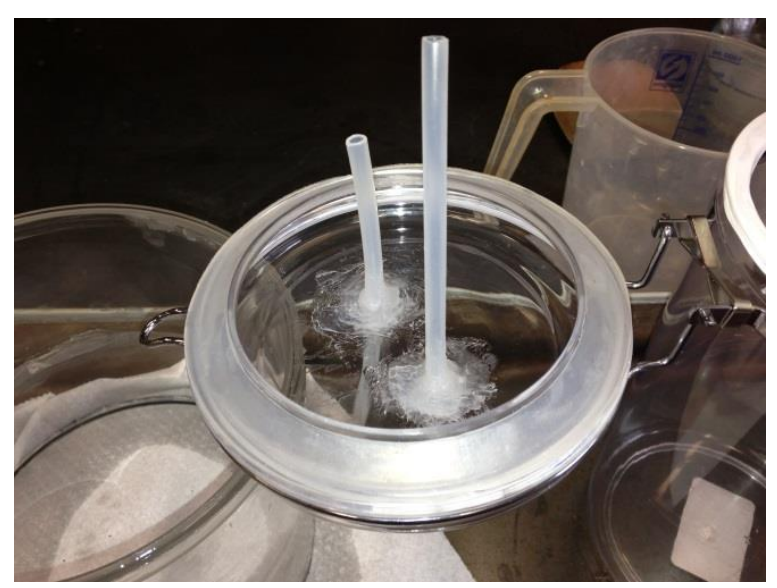

(b)

Figura 3.29 - Detalhes da preparação do reservatório de solução salina. 
$\sqrt{ }$ Sistema de circulação de vapor

Para acelerar a transferência de umidade entre o vapor de água do reservatório de solução salina e o corpo de prova acoplado na célula edométrica optou-se utilizar uma bomba para forçar a circulação de vapor. Essa bomba tem a função de sugar o vapor de água do reservatório, e levar até a célula, trabalhando em um sistema fechado, e sem a contaminação do ar pelo funcionamento da mesma.

A bomba utilizada para circulação foi uma adaptação de uma bomba de aquário, onde foram feitas algumas modificações para que o sistema ficasse completamente fechado. A Figura 3.30 mostra a bomba utilizada e já instalada.

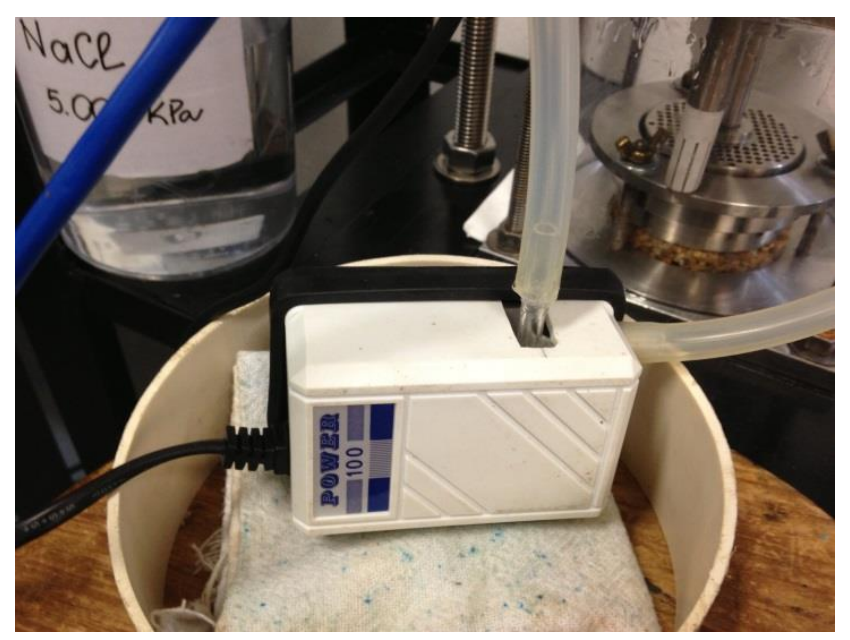

Figura 3.30 - Bomba de ar para circulação do vapor.

A Figura 3.31 ilustra os detalhes das modificações e adaptações realizadas na bomba de aquário, com abertura na lateral para colagem do cano de acrílico para colocação da mangueira. 


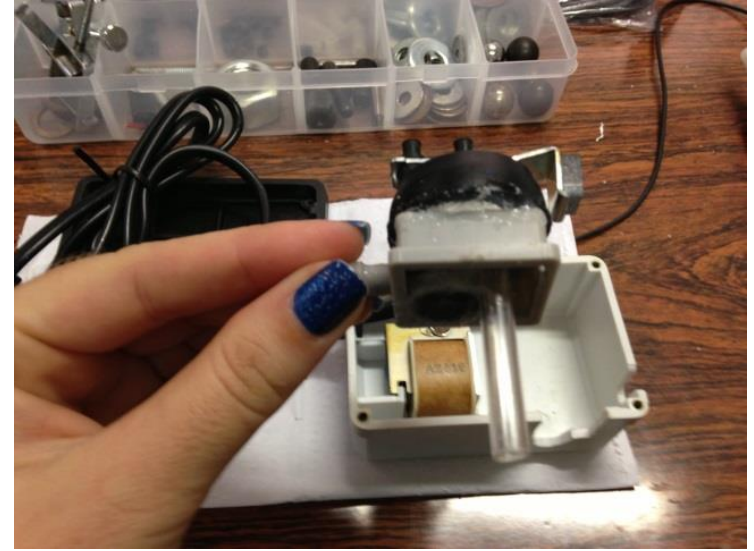

(a)

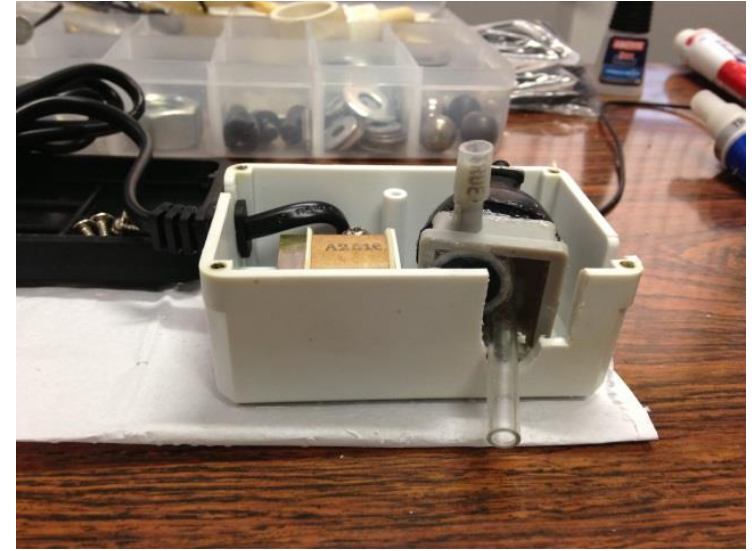

(b)

Figura 3.31 - Detalhes da adaptação na bomba de circulação de ar.

$\sqrt{ }$ Sistema de Aquisição de Dados

Como citado anteriormente, foram confeccionadas cinco prensas, sendo quatro para transferência de vapor e uma para expansão inundada, então, foi necessário desenvolver uma caixa coletora de dados, e também, alimentadora para as cinco células de carga que trabalharam ao mesmo tempo. A Figura 3.32 apresenta a caixa de aquisição e compilação dos dados.

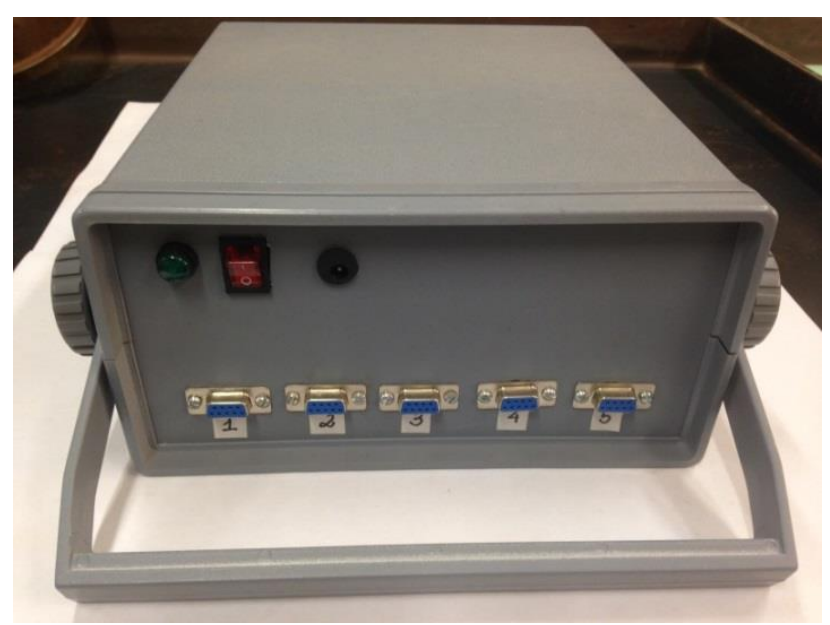

Figura 3.32 - Sistema de aquisição de dados.

De acordo com a Figura 3.33, dentro da caixa contém: fontes para as cinco células de carga; aquisitor de dados com 64 canais receptores da marca NOVUS; cinco entradas de sinais das células de carga; e uma saída de sinal que é transferido para o computador, por meio do software citado anteriormente. 


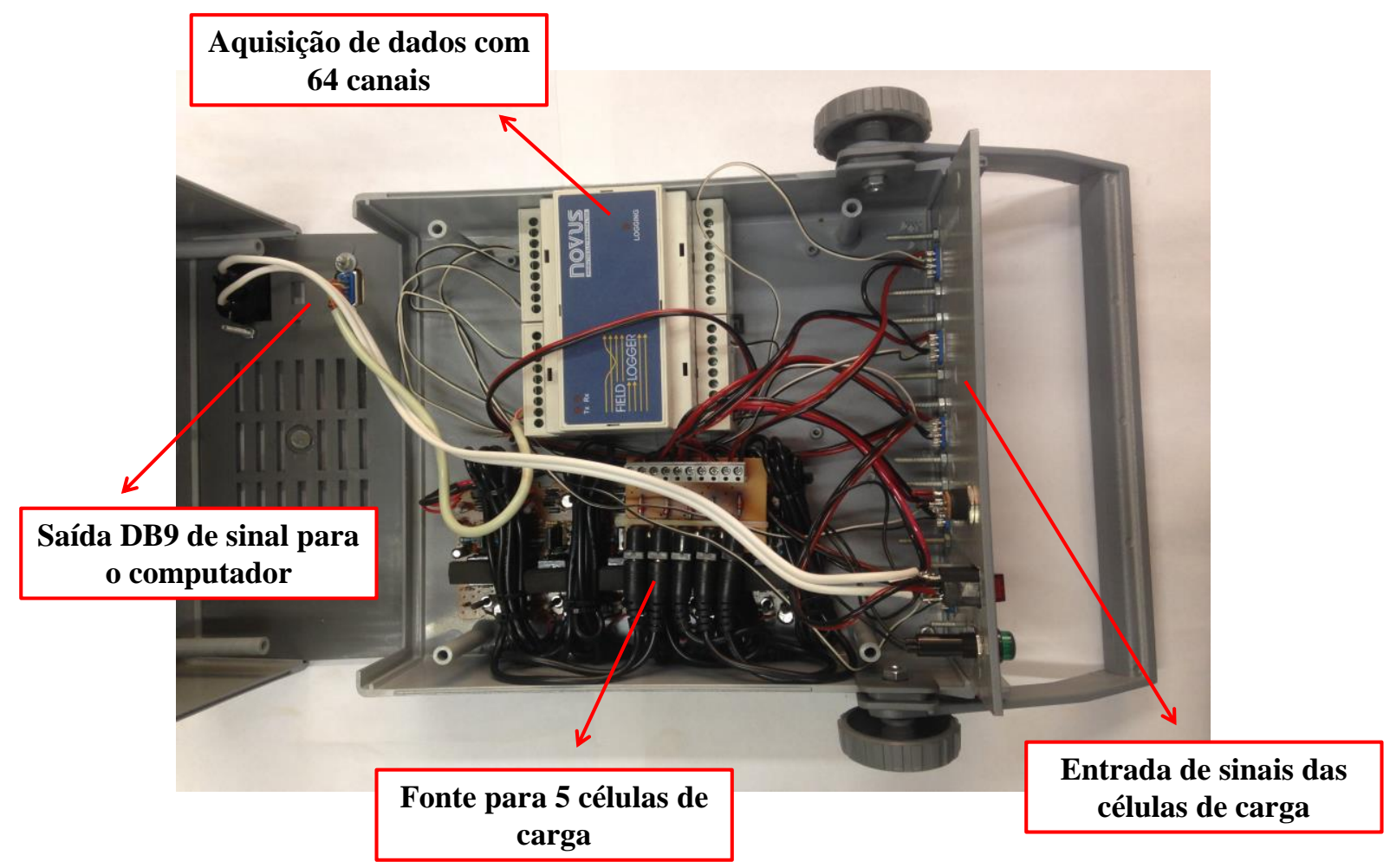

Figura 3.33 - Montagem do sistema de aquisição de dados.

A Figura 3.34 mostra a disposição geral do equipamento completo, com conjunto de prensas e sistema de aquisição de dados ligado ao computador.

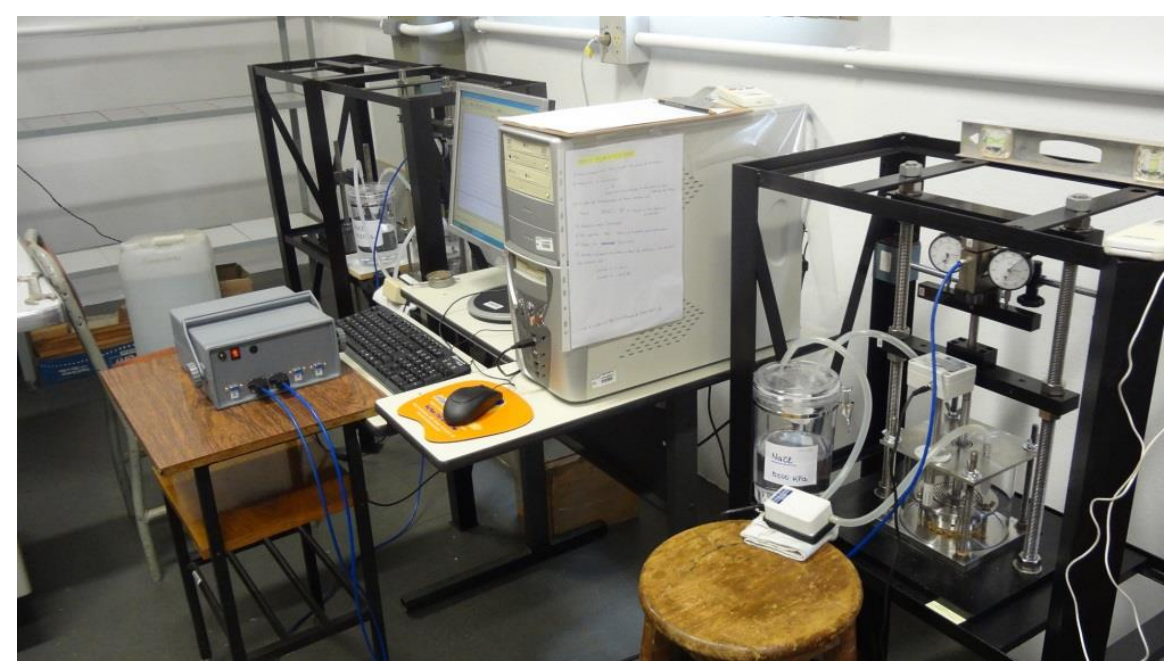

Figura 3.34 - Disposição das prensas para medição da expansão com sistema de aquisição de dados. 


\section{APRESENTAÇÃO DOS RESULTADOS}

São apresentados neste capítulo resultados de caracterização geotécnica dos materiais da Formação Corumbataí e Formação Botucatu, bem como, algumas características da bentonita. Apresenta-se, também, a caracterização físico-química por meio de ensaios de análise térmica gravimétrica, difração em raios-x e determinação da capacidade de troca de cátions. Em seguida, são mostradas as curvas de retenção determinada por diferentes técnicas. E, por fim, os resultados de pressão de expansão para as combinações de materiais, metodologias empregadas e correlações de parâmetros de expansão.

\subsection{Ensaios de Caracterização Geotécnica}

As curvas de distribuição granulométrica dos materiais ensaiados estão apresentadas na Figura 4.1. Na Tabela 4.1 são mostradas as características dos respectivos materiais empregados nesta pesquisa, como: índices físicos (massa específica dos sólidos, massa específica seca, umidade ótima), porcentagens dos materiais, limites de consistência. O material arenoso da Formação Botucatu foi caracterizado por Loch (2013).

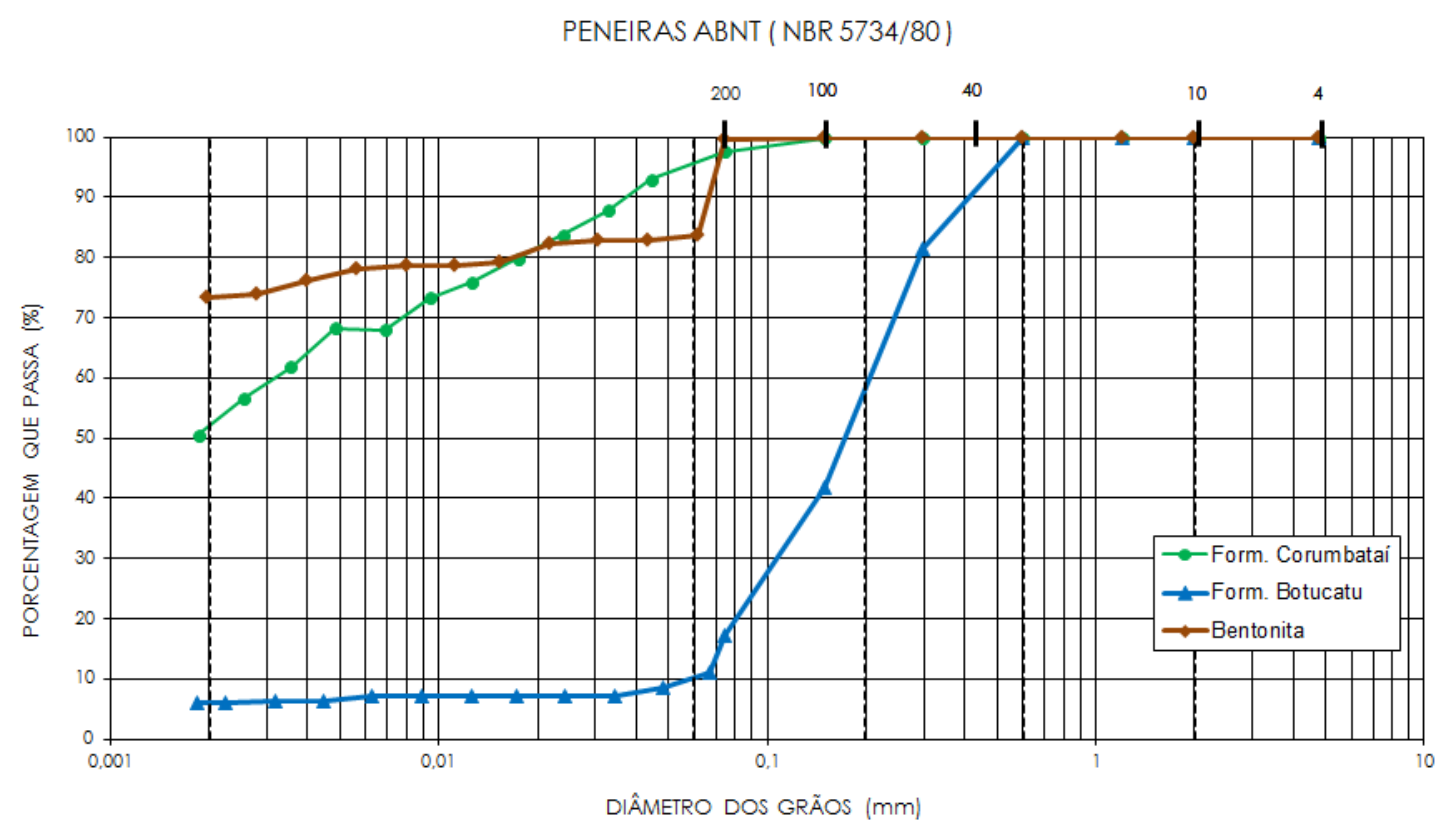

Figura 4.1 - Curvas de distribuição granulométrica dos materiais analisados. 
Na Tabela 4.1 é possível observar que o material da Formação Corumbataí possui elevado teor de argila, podendo ser classificada segundo a Associação Brasileira de Normas Técnicas (ABNT: 7181/84), como argila siltosa. Na classificação AASHTO M 14591 (2004), trata-se de uma amostra pertencente ao grupo A7. De acordo com Sistema Unificado de Classificação de Solos (SUCS), de Casagrande (1948), o solo está classificado como argila inorgânica de alta plasticidade. O material da Formação Botucatu apresenta elevado teor de areia fina e média, e uma pequena fração de argila e silte. Na classificação SUCS, o material é denominado de areia mal graduada com argila.

Tabela 4.1 - Características geotécnicas dos materiais.

\begin{tabular}{rc|c}
\cline { 2 - 3 } & Form. Corumbataí & Form. Botucatu \\
\hline$\%$ argila & 50 & 6 \\
$\%$ silte & 45 & 4 \\
$\%$ areia & 5 & 90 \\
$\mathrm{w}_{\text {ot }}(\%)$ & 23,7 & 6,4 \\
$\rho_{\mathrm{s}}\left(\mathrm{g} / \mathrm{cm}^{3}\right)$ & 2,69 & 2,63 \\
$\rho\left(\mathrm{g} / \mathrm{cm}^{3}\right)$ & 1,81 & 1,76 \\
$\rho_{\mathrm{d}}\left(\mathrm{g} / \mathrm{cm}^{3}\right)$ & 1,47 & 1,93 \\
$\mathrm{e}$ & 0,84 & 0,55 \\
$\mathrm{n}(\%)$ & 45,65 & 36 \\
$\mathrm{Sr}(\%)$ & 76,24 & 18,99 \\
$\mathrm{LL}(\%)$ & 76 & - \\
$\mathrm{LP}(\%)$ & 32 & $\mathrm{np}$ \\
$\mathrm{IP}(\%)$ & 44 & - \\
\hline
\end{tabular}

A curva granulométrica da bentonita apresentou elevada porcentagem de finos, configurando um material altamente argiloso. A massa específica dos sólidos $\left(\rho_{\mathrm{s}}\right)$ deste material foi de 2,74 $\mathrm{g} / \mathrm{cm}^{3}$. As curvas de compactação dos materiais da Formação Corumbataí e Formação Botucatu estão apresentadas na Figura 4.2. 


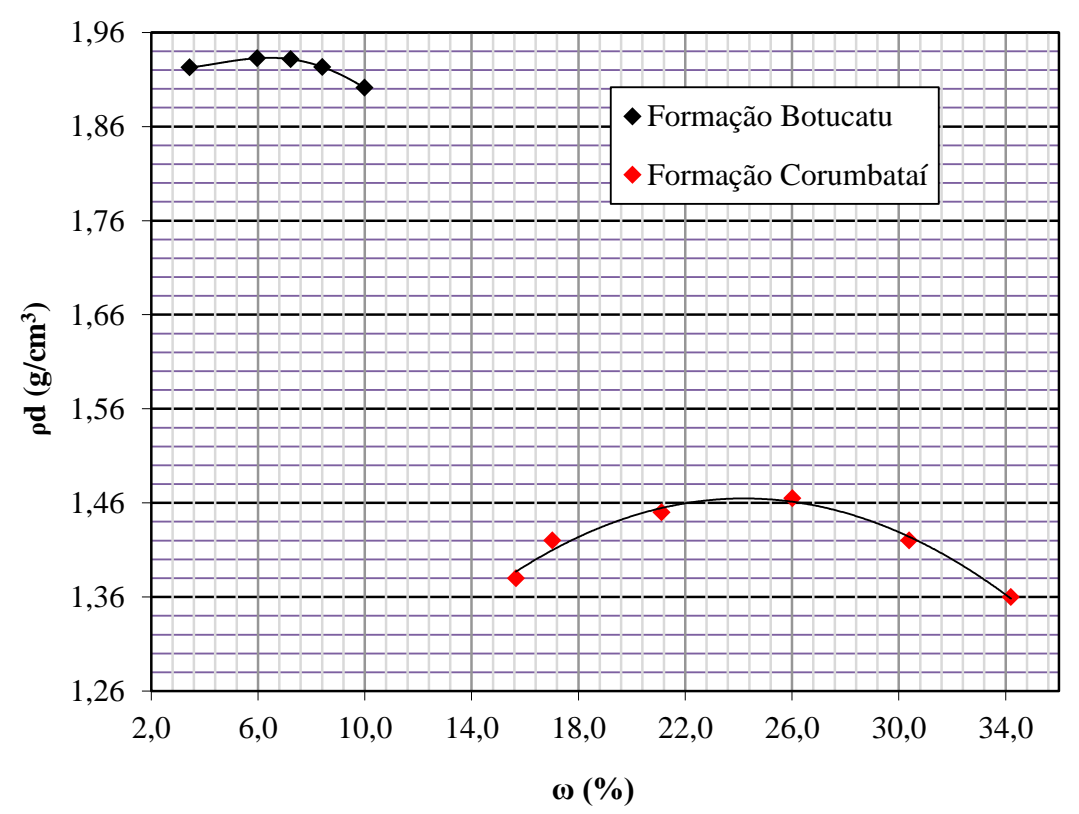

Figura 4.2 - Curvas de compactação do Material argiloso da Formação Corumbataí e do Material arenoso da Formação Botucatu (Loch, 2013).

Quanto aos índices físicos, segundo a IAEG (1979), o material argiloso apresenta um grau de saturação elevado (próximo de 80\%), índice de vazios alto (próximo de 0,9), e também porosidade elevada (entre 45 e 50\%). Os limites de liquidez e plasticidade mostram-se elevados, com índice de plasticidade indicando um material muito plástico. Pela classificação de Williams e Donaldson (1980), a qual relaciona a porcentagem de argila com índice de plasticidade, o material é classificado com “expansão muito alta". Já o material arenoso apresentou dificuldades na obtenção dos limites de consistência.

A simples análise das características da amostra da Formação Corumbataí permite realizar constatações empíricas citadas por Chen (1975) a fim de prever um comportamento expansivo. $\mathrm{O}$ autor realizou estudos em solos de regiões montanhosas dos Estados Unidos e verificou que os solos compostos por $95 \%$ de partículas com diâmetro inferior a 0,074 mm LL $>60 \%$ devem apresentar um alto potencial de expansão. Os resultados obtidos nos ensaios de caracterização dessa pesquisa corroboram as constatações do autor, e mostram que o material apresenta indícios de ser expansivo. 


\subsection{Ensaios de Caracterização Mineralógica}

\subsubsection{Análise Térmica Diferencial (ATD)}

A Figura 4.3 mostra os termogramas obtidos na análise térmica diferencial (ATD). Foi utilizado cerca de $1,0 \mathrm{~g}$ de material passado na peneira \#400 $(0,0038 \mathrm{~mm})$. A Tabela 4.2 apresenta uma possível interpretação de cada pico presente nos termogramas, com base em Grim (1953), Mackenzie (1957) e Santos (1989).

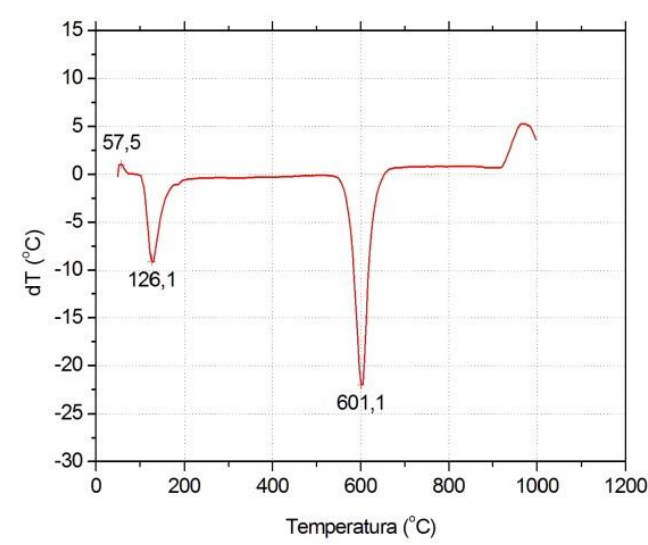

(a)

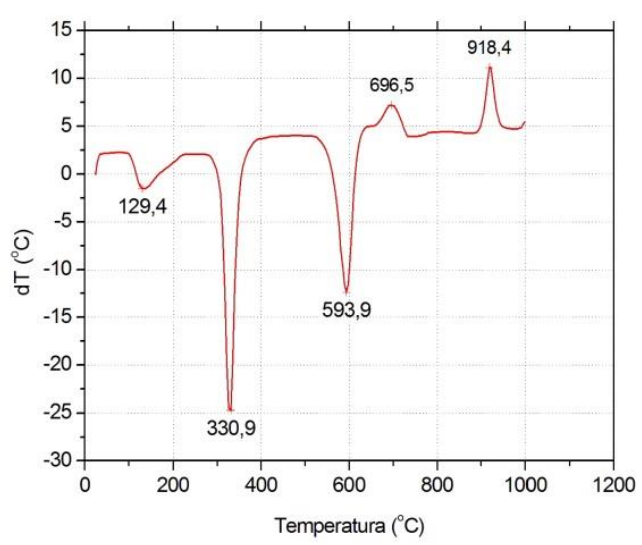

(b)

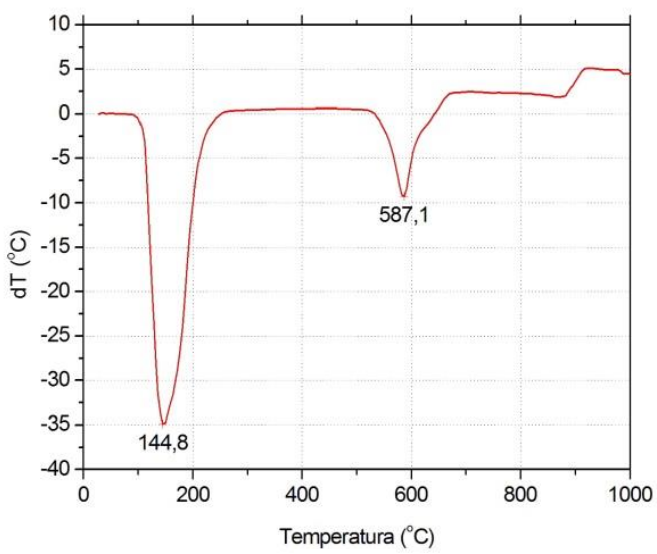

(c)

Figura 4.3 - Termogramas obtidos nas análıses térmicas diferencial (ATD): (a) Material da Formação Corumbataí; (b) Material da Formação Botucatu; (c) Bentonita.

$\mathrm{Na}$ curva de reação do material da Formação Corumbataí (Figura 4.3(a)), o primeiro pico endotérmico ocorre a $126^{\circ} \mathrm{C}$, característico de argilomineral do grupo da montmorilonita. Já o segundo pico endotérmico ocorre a aproximadamente $600^{\circ} \mathrm{C}$, temperatura dentro do intervalo de desidroxilação característico da caulinita que está entre $450^{\circ} \mathrm{C}$ e $600^{\circ} \mathrm{C}$ (Santos, 1989). 
A curva de reação do material da Formação Botucatu (Figura 4.3(b)) apresenta dois picos endotérmicos acentuados configurando os argilominerais gibsita e caulinita/quartzo, e um pico exotérmico à $918^{\circ} \mathrm{C}$ da nucleação da mulita. A bentonita (Figura 4.3(c)) apresentou um termograma com pico endotérmico peculiar de argilominerais do grupo das esmectitas sódicas, e um segundo pico possivelmente do quartzo. O pico que se destaca na bentonita é característico de argilominerais montmorilonítico sódico (Santos, 1989).

Tabela 4.2 - Identificação dos minerais por pico.

\begin{tabular}{ccccc}
\hline Material & Pico & $\begin{array}{c}\text { Condição } \\
\text { Térmica }\end{array}$ & To & Mineral Provável \\
\hline Formação & 2 & Endotérmico & 126,1 & Montmorilonita/Ilita \\
Corumbataí & 3 & Endotérmico & 601,1 & Caulinita \\
\hline Formação & 2 & Endotérmico & 330,9 & Gibsita \\
Botucatu & 3 & Endotérmico & 593,9 & Caulinita/Quartzo \\
& 5 & Exotérmico & 918,4 & Nucleação da Mulita \\
\hline \multirow{2}{*}{ Bentonita } & 1 & Endotérmico & 144,8 & Montmorilonita Sódica \\
& 2 & Endotérmico & 587,1 & Quartzo \\
\hline
\end{tabular}

\subsubsection{Difração de Raios-X}

Os difratogramas obtidos na difração de raios-x estão apresentados na Figura 4.4, representados pelo ângulo de reflexão (20) versus a intensidade. O ensaio foi realizado com lâminas dos materiais preparadas em três diferentes procedimentos: normal, aquecida à $550^{\circ} \mathrm{C}$ e tratada com etilenoglicol. Os picos que predominam em cada tipo de material são mostrados na Figura 4.4 com os respectivos valores da distância interplanar basal d (ângstron). 


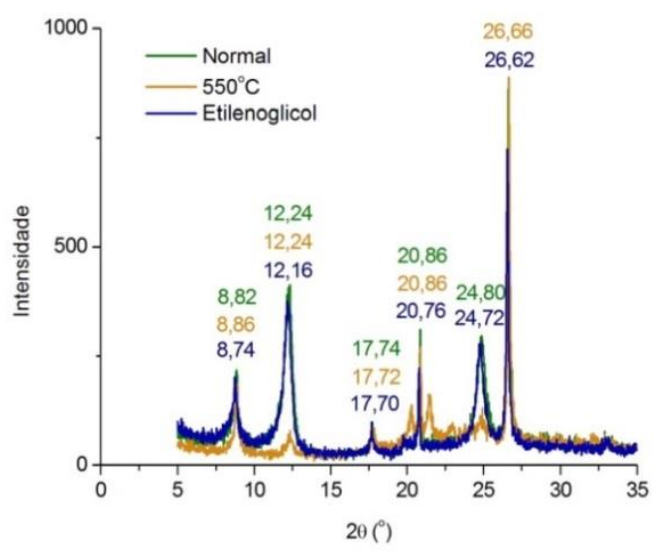

(a)

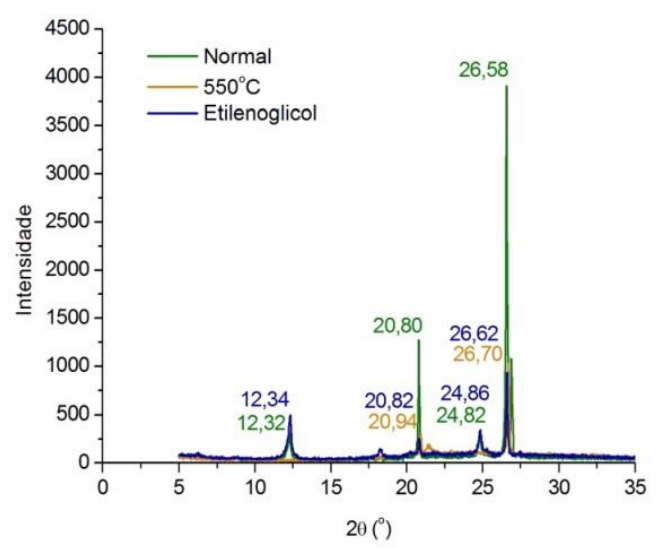

(b)

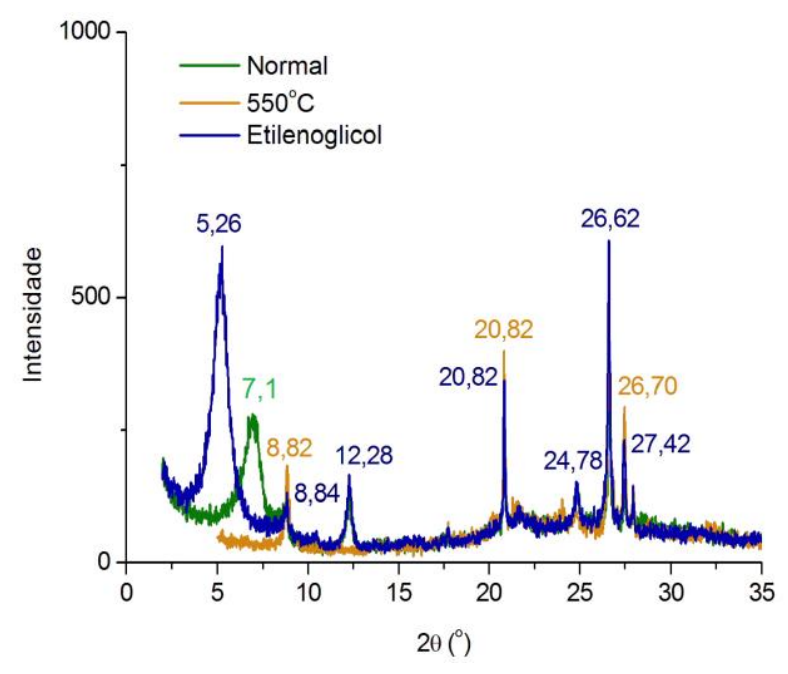

(c)

Figura 4.4 - Difratogramas de Raios-X para lâminas tratadas nos procedimentos normal, aquecida à $550^{\circ} \mathrm{C}$ e banhadas na solução de etilenoglicol: (a) Amostra da Formação

Corumbataí; (b) Amostra da Formação Botucatu; (c) Bentonita.

O material argiloso (Figura 4.4(a)) apresenta argilominerais do grupo da caulinita e das micas (ilita), enquanto que o material arenoso (Figura 4.4(b)) é constituído, basicamente, de quartzo e caulinita. A bentonita (Figura 4.4(c)) apresentou o argilomineral expansivo montmorilonita e a caulinita. 
Tabela 4.3 - Identificação dos minerais a partir dos difratogramas de raios-X.

\begin{tabular}{|c|c|c|c|c|c|}
\hline \multirow{2}{*}{ Material } & \multirow{2}{*}{ Procedimento } & \multirow{2}{*}{ Picos } & \multicolumn{2}{|c|}{ Parâmetros } & \multirow{2}{*}{ Mineral Provável } \\
\hline & & & $2 \theta$ & d & \\
\hline \multirow{16}{*}{$\begin{array}{c}\text { Form. } \\
\text { Corumbataí }\end{array}$} & \multirow{6}{*}{ Normal } & 1 & 8,8 & 10,0 & Ilita \\
\hline & & 2 & 12,2 & 7,2 & Caulinita \\
\hline & & 3 & 17,7 & 5,0 & Mica/Ilita \\
\hline & & 4 & 20,9 & 4,3 & Quartzo \\
\hline & & 5 & 24,8 & 3,6 & Caulinita \\
\hline & & 6 & 26,6 & 3,3 & Quatzo \\
\hline & \multirow{4}{*}{$550^{\circ} \mathrm{C}$} & 1 & 8,9 & 10,0 & Ilita \\
\hline & & 2 & 12,2 & 7,2 & Caulinita \\
\hline & & 3 & 17,7 & 5,0 & Mica/Ilita \\
\hline & & 4 & 20,9 & 4,3 & Quartzo \\
\hline & \multirow{6}{*}{ Etilenoglicol } & 1 & 8,7 & 10,1 & Ilita \\
\hline & & 2 & 12,2 & 7,3 & Caulinita \\
\hline & & 3 & 17,7 & 5,0 & Mica/Ilita \\
\hline & & 4 & 20,8 & 4,3 & Quartzo \\
\hline & & 5 & 24,8 & 3,6 & Caulinita \\
\hline & & 6 & 26,5 & 3,4 & Quartzo \\
\hline \multirow{10}{*}{$\begin{array}{c}\text { Form. } \\
\text { Botucatu }\end{array}$} & \multirow{4}{*}{ Normal } & 1 & 26,6 & 3,4 & Quartzo \\
\hline & & 2 & 20,8 & 4,3 & Quartzo \\
\hline & & 3 & 12,3 & 7,2 & Caulinita \\
\hline & & 4 & 24,8 & 3,6 & Caulinita \\
\hline & \multirow{2}{*}{$550^{\circ} \mathrm{C}$} & 1 & 26,7 & 3,3 & Quartzo \\
\hline & & 2 & 20,9 & 4,2 & Quartzo \\
\hline & \multirow{4}{*}{ Etilenoglicol } & 1 & 26,6 & 3,3 & Quartzo \\
\hline & & 2 & 12,3 & 7,2 & Caulinita \\
\hline & & 3 & 24,9 & 3,6 & Caulinita \\
\hline & & 4 & 20,8 & 4,3 & Quartzo \\
\hline \multirow{14}{*}{ Bentonita } & \multirow{5}{*}{ Normal } & 1 & 7,1 & 12,5 & Montmorilonita \\
\hline & & 2 & 12,3 & 7,2 & Caulinita \\
\hline & & 3 & 20,9 & 4,3 & Quartzo \\
\hline & & 4 & 24,8 & 3,6 & Caulinita \\
\hline & & 5 & 26,6 & 3,3 & Quartzo \\
\hline & \multirow{3}{*}{$550^{\circ} \mathrm{C}$} & 1 & 8,8 & 10,0 & Montmorilonita \\
\hline & & 2 & 20,8 & 4,3 & Quartzo \\
\hline & & 3 & 26,6 & 3,3 & Quartzo \\
\hline & \multirow{6}{*}{ Etilenoglicol } & 1 & 5,3 & 16,8 & Montmorilonita \\
\hline & & 2 & 8,8 & 10,0 & Ilita \\
\hline & & 3 & 12,3 & 7,2 & Caulinita \\
\hline & & 4 & 20,8 & 4,3 & Quartzo \\
\hline & & 5 & 24,8 & 3,6 & Caulinita \\
\hline & & 6 & 26,6 & 3,3 & Quartzo \\
\hline
\end{tabular}

* (Loch, 2013)

Os resultados dos difratogramas para os diferentes métodos de preparação das lâminas para o ensaio apresentaram conformidade na determinação dos argilominerais que compõem cada material, confirmando as informações obtidas em cada resposta ao tipo de tratamento. 
A ausência na identificação de minerais expansivos do grupo da esmectita (montmorilonita) na amostra de material argiloso da Formação Corumbataí pode ser esclarecida pela variação que ocorre nas porções de argilominerais, pela granulometria muito fina e pela fração argila, o que dificulta a orientação preferencial (Santos, 1989).

\subsubsection{Adsorção de Azul de Metileno}

Os resultados do ensaio de azul de metileno pelo método da mancha são mostrados na Tabela 4.4. Foram utilizadas aproximadamente $0,5 \mathrm{~g}$ de amostra da Formação Corumbataí e de Bentonita, e 5,0g de material da Formação Botucatu. A concentração de azul de metileno para os solos argiloso e arenoso foi de $1,5 \mathrm{~g} / \mathrm{L}$, e para a bentonita foi de $5,0 \mathrm{~g} / \mathrm{L}$. Os parâmetros calculados foram: a capacidade de troca de cátions (CTC), a superfície específica (SE) e o valor de azul de metileno ( $\mathrm{Vb})$. A partir destes parâmetros determinaram-se os possíveis minerais presentes nas amostras.

Tabela 4.4 - Parâmetros calculados no ensaio de azul de metileno.

\begin{tabular}{ccccc}
\hline Amostras & CTC $_{\text {arg }}(\mathbf{m e q} / \mathbf{1 0 0 g})$ & $\mathbf{S E ~}\left(\mathbf{m}^{2} / \mathbf{g}\right)$ & $\mathbf{V b}(\mathbf{g} / \mathbf{1 0 0 g})$ & Mineral Provável \\
\hline Form. Corumbataí & 29,31 & 114,69 & 4,69 & Haloisita + Ilita \\
Form. Botucatu & 14,07 & 6,61 & 0,27 & Caulinita \\
Bentonita & 88,71 & 513,66 & 21,0 & Montmorilonita \\
\hline
\end{tabular}

Os valores da CTC para caracterização dos argilominerais presentes na amostra confirmam os resultados obtido no difratograma de raios-x. A amostra de solo argiloso indica a presença dos argilominerais do grupo da caulinita (haloisita), e do grupo das micas (ilita). A CTC da bentonita confirma a presença do argilomineral montmorilonítico. E a caulinita é confirmada na amostra arenosa. A atividade da porcentagem de argilomineral $\left(\mathrm{A}_{\mathrm{cb}}\right)$ das amostras é apresentadas na Tabela 4.5 de acordo com a classificação proposta por Lautrin (1989).

Tabela 4.5 - Atividade dos argilominerais presente nas amostras (Lautrin, 1989).

\begin{tabular}{ccccc}
\hline Amostras & $\mathbf{V b}$ & \% Arg. & $\mathbf{A}_{\mathbf{c b}}$ & Atividade \\
\hline Form. Corumbataí & 4,69 & 50 & 9,4 & Ativa \\
Form. Botucatu & 0,27 & 6 & 4,5 & Pouco Ativa \\
Bentonita & 21,00 & 74 & 28,4 & Nociva \\
\hline
\end{tabular}




\subsection{Curvas de Retenção de Água}

As curvas de retenção de água foram determinadas em laboratório pelos métodos do papel filtro e dessecador a vácuo para as amostras da Formação Corumbataí nas condições indeformada e compactada. Os resultados dos ensaios permitiram determinar curvas representativas dos dados em função da sucção matricial ou sucção total $(\mathrm{kPa})$ versus a umidade gravimétrica $(\%)$.

\subsubsection{Papel Filtro}

As curvas de retenção pelo método do papel filtro foram determinadas pelos processos de secagem e umedecimento em função da sucção matricial. Foram determinadas também, as curvas de retenção em função da sucção total pelo processo de umedecimento.

Os dados experimentais foram ajustados de acordo com o modelo matemático proposto por van Genuchten (1980) e Fredlung e Xing (1994) através do software Grapher versão 9.1. A curva de retenção para a amostra indeformada pelo processo de umedecimento é apresentada na Figura 4.5 com valores de sucção total versus umidade gravimétrica, e os respectivos ajustes matemáticos.

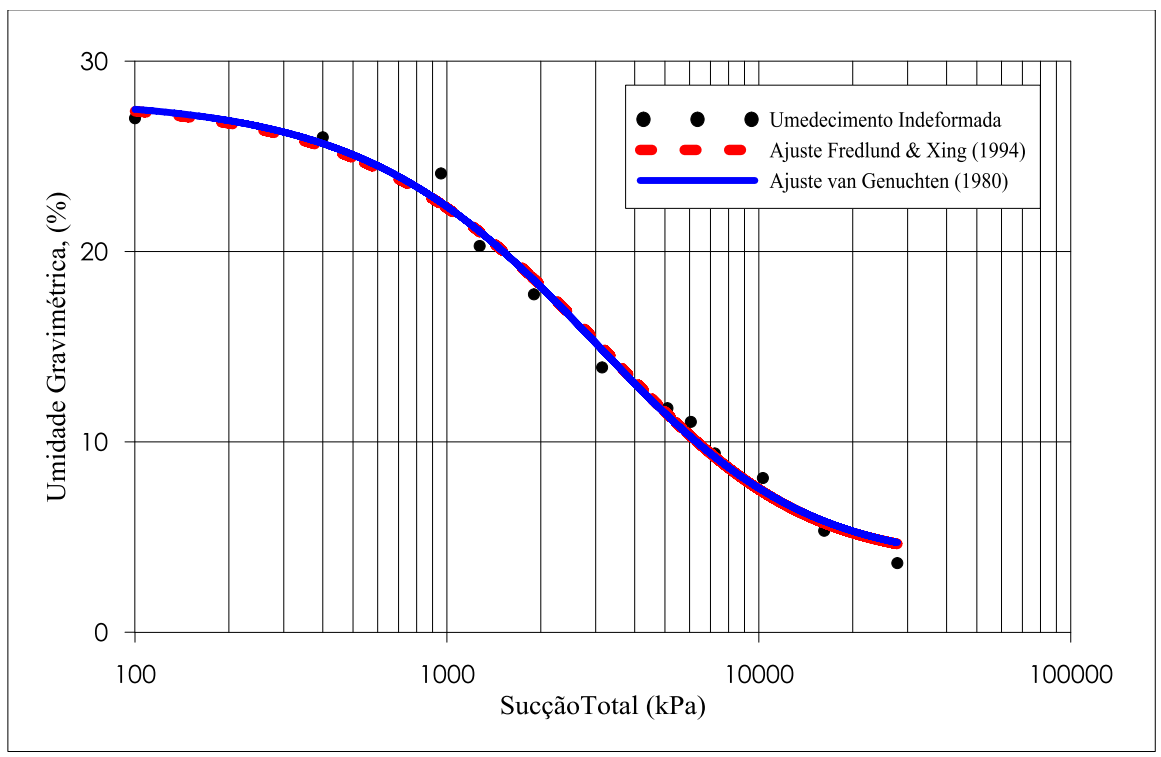

Figura 4.5 - Curva de retenção pelo método do papel filtro com trajetória de umedecimento para a amostra indeformada da Formação Corumbataí. 
A Figura 4.6 apresenta a curva de retenção para a amostra compactada pelo processo de umedecimento com valores de umidade gravimétrica versus sucção total, e os respectivos ajustes matemáticos.

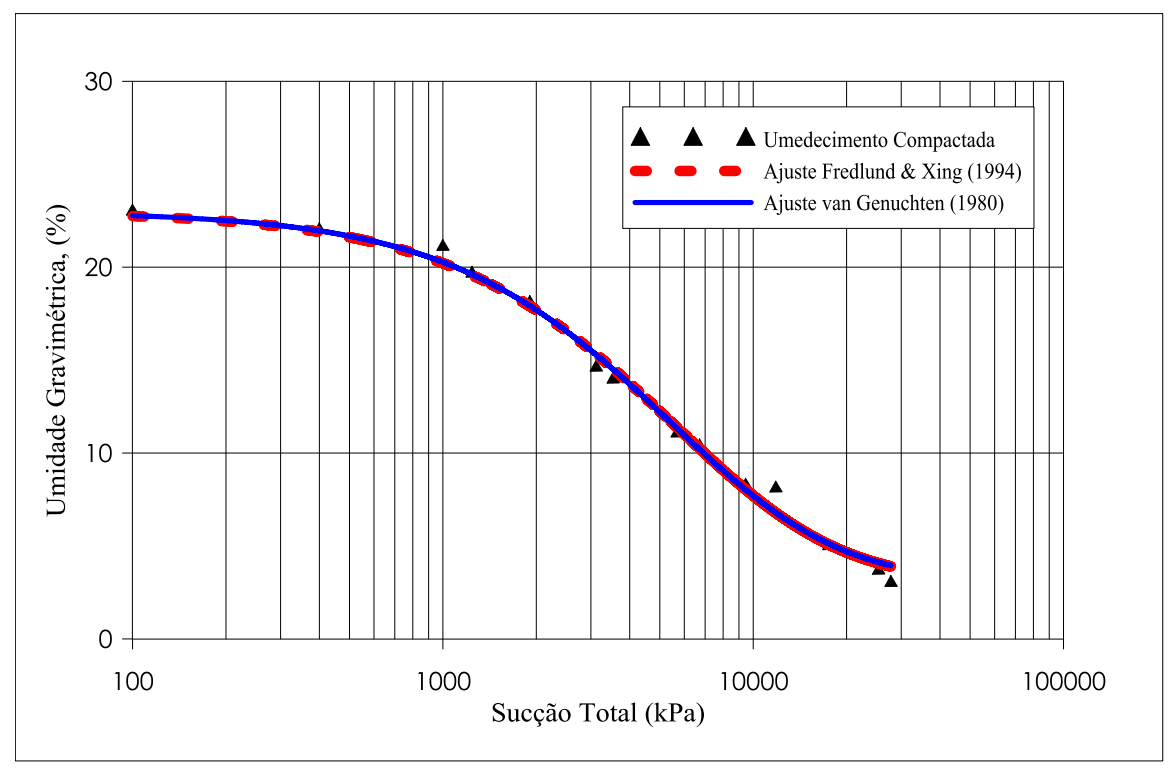

Figura 4.6 - Curva de retenção pelo método do papel filtro com trajetória de umedecimento para a amostra compactada da Formação Corumbataí.

Os parâmetros de ajuste e os coeficientes de determinação $\left(\mathrm{r}^{2}\right)$ para as curvas de retenção com sucção total nas condições indeformada e compactada estão mostrados na Tabela 4.6.

Tabela 4.6 - Parâmetros de ajuste dos modelos matemáticos aos dados experimentais da curva de retenção com sucção total das amostras indeformada e compactada.

\begin{tabular}{ccccccc}
\hline Parâmetros de Ajuste - van Genuchten (1980) & $\mathbf{w}_{\text {res }}(\boldsymbol{\%})$ & $\mathbf{w}_{\text {sat }}(\boldsymbol{\%})$ & $\boldsymbol{\alpha}$ & $\mathbf{n}$ & $\mathbf{m}$ & $\mathbf{r}^{\mathbf{2}}$ \\
\hline Am. Indeformada & 3,6 & 28,0 & 0,00025 & 1,1187 & 1,3676 & 0,99 \\
Am. Compactada & 3,0 & 23,0 & 8,5435 & 1,1200 & 2,3830 & 0,99 \\
\hline Parâmetros de Ajuste - Fredlund \& Xing (1994) & $\mathbf{w}_{\text {res }}(\boldsymbol{\%})$ & $\mathbf{w}_{\mathbf{s a t}}(\boldsymbol{\%})$ & $\mathbf{a}$ & $\mathbf{n}$ & $\mathbf{m}$ & $\mathbf{r}^{\mathbf{2}}$ \\
\hline Am. Indeformada & 3,6 & 28,0 & 5196,54 & 1,0308 & 4,2350 & 0,99 \\
Am. Compactada & 3,0 & 23,0 & 12660,20 & 1,0797 & 6,4750 & 0,99 \\
\hline
\end{tabular}

As curvas de retenção determinadas em termos de sucção total pelo processo de umedecimento apresentaram características semelhantes para a condição indeformada e compactada. A pressão de entrada de ar para a amostra indeformada e compactada foi de 800 $\mathrm{kPa}$ e $1.000 \mathrm{kPa}$, respectivamente. O intervalo de dessaturação das curvas ficou entre $800 \mathrm{kPa}$ e $40.000 \mathrm{kPa}$ aproximadamente. Os modelos de van Genuchten (1980) e Fredlund \& Xing (1993) apresentaram ajustes de qualidade aos dados experimentais, com coeficientes de determinação $\left(\mathrm{r}^{2}\right)$ próximos de 1 . 
Foram determinadas as curvas de retenção para sucção matricial com trajetórias de umedecimento e secagem. A Figura 4.7 apresenta o gráfico com as respectivas curvas para a amostra indeformada. Os pontos experimentais correspondentes ao intervalo de 1 a $13 \mathrm{kPa}$ foram obtidos pelo método do funil de placa porosa.

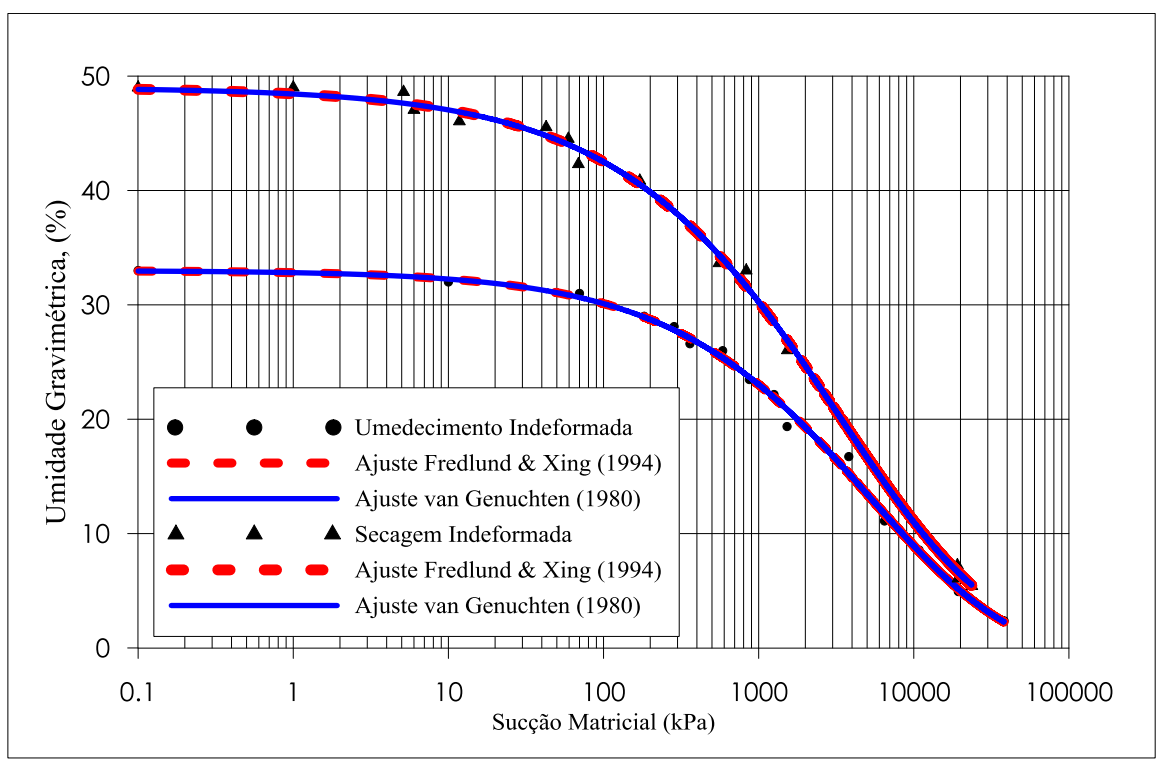

Figura 4.7 - Curvas de retenção pelo método do papel filtro com trajetória de umedecimento e secagem para a amostra indeformada da Formação Corumbataí.

Os parâmetros de ajuste e os coeficientes de determinação $\left(\mathrm{r}^{2}\right)$ para as curvas de retenção com sucção matricial na condição indeformada estão mostrados na Tabela 4.7 para a trajetória de secagem, e na Tabela 4.8 para a trajetória de umedecimento.

Tabela 4.7 - Parâmetros de ajuste dos modelos matemáticos aos dados experimentais da curva de retenção com sucção matricial da amostra indeformada para a trajetória de secagem.

\begin{tabular}{ccccccc}
\hline Parâmetros de Ajuste - van Genuchten (1980) & $\mathbf{w}_{\text {res }}(\boldsymbol{\%})$ & $\mathbf{w}_{\text {sat }}(\boldsymbol{\%})$ & $\boldsymbol{\alpha}$ & $\mathbf{n}$ & $\mathbf{m}$ & $\mathbf{r}^{\mathbf{2}}$ \\
\hline Am. Indeformada Secagem & $-0,001$ & 49,0 & 2,3528 & 0,5487 & 4,0061 & 0,99 \\
\hline Parâmetros de Ajuste - Fredlund \& Xing (1994) & $\mathbf{w}_{\text {res }}(\boldsymbol{\%})$ & $\mathbf{w}_{\mathbf{s a t}}(\boldsymbol{\%})$ & $\mathbf{a}$ & $\mathbf{n}$ & $\mathbf{m}$ & $\mathbf{r}^{\mathbf{2}}$ \\
\hline Am. Indeformada Secagem & $-3,1$ & 49,0 & 8459,9594 & 0,5584 & 4,4425 & 0,99 \\
\hline
\end{tabular}

Tabela 4.8 - Parâmetros de ajuste dos modelos matemáticos aos dados experimentais da curva de retenção com sucção matricial da amostra indeformada para a trajetória de umedecimento.

\begin{tabular}{ccccccc}
\hline Parâmetros de Ajuste - van Genuchten (1980) & $\mathbf{w}_{\text {res }}(\boldsymbol{\%})$ & $\mathbf{w}_{\mathbf{s a t}}(\boldsymbol{\%})$ & $\boldsymbol{\alpha}$ & $\mathbf{n}$ & $\mathbf{m}$ & $\mathbf{r}^{\mathbf{2}}$ \\
\hline Am. Indeformada Umedecimento & $-1,0$ & 33,0 & 2,4504 & 0,6076 & 3,4740 & 0,99 \\
\hline Parâmetros de Ajuste - Fredlund \& Xing (1994) & $\mathbf{w}_{\text {res }}(\boldsymbol{\%})$ & $\mathbf{w}_{\text {sat }}(\boldsymbol{\%})$ & $\mathbf{a}$ & $\mathbf{n}$ & $\mathbf{m}$ & $\mathbf{r}^{\mathbf{2}}$ \\
\hline Am. Indeformada Umedecimento & $-1,4$ & 33,0 & 22183,3 & 0,6087 & 6,4815 & 0,99 \\
\hline
\end{tabular}

A Figura 4.8 apresenta a curva de retenção para a amostra compactada pelo processo de umedecimento e secagem com valores de umidade gravimétrica versus sucção matricial. 
Novamente, os pontos experimentais correspondentes ao intervalo de 1 a $13 \mathrm{kPa}$ foram obtidos pelo método do funil de placa porosa.

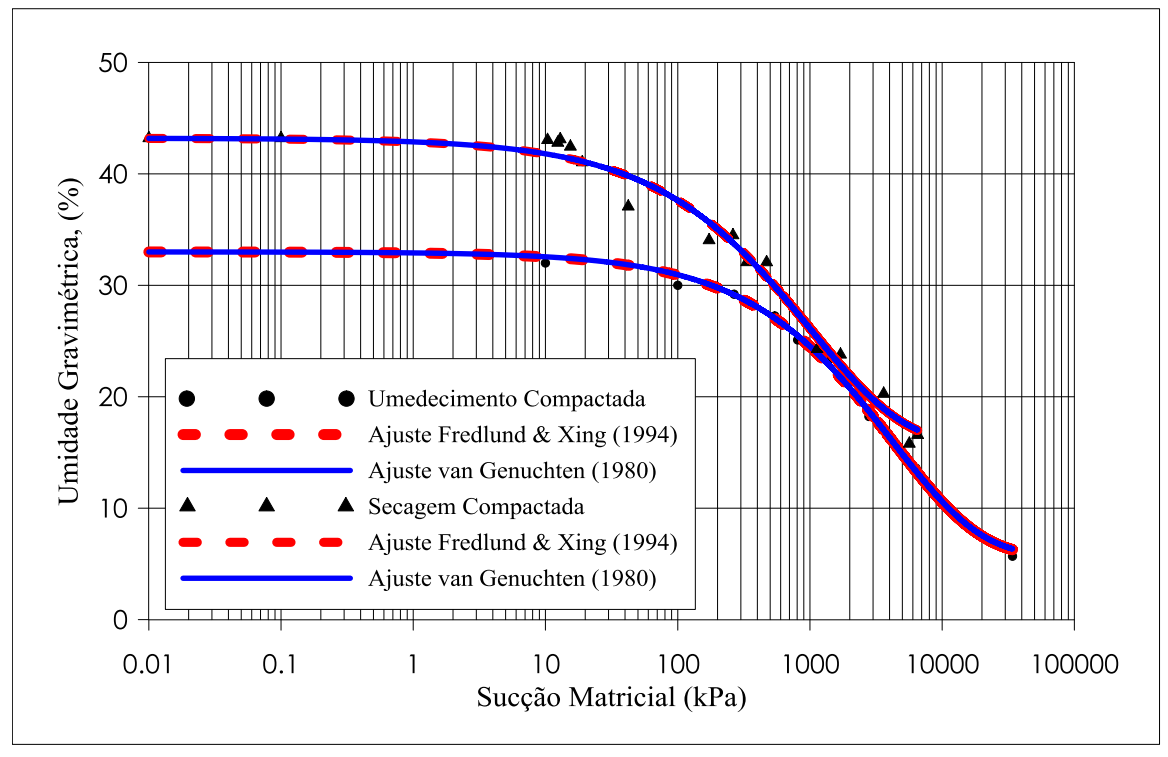

Figura 4.8 - Curvas de retenção pelo método do papel filtro com trajetória de umedecimento e secagem para a amostra compactada da Formação Corumbataí.

Os parâmetros de ajuste e os coeficientes de determinação $\left(\mathrm{r}^{2}\right)$ para as curvas de retenção com sucção matricial na condição compactada estão mostrados na Tabela 4.9 para a trajetória de secagem, e na Tabela 4.10 para a trajetória de umedecimento.

Tabela 4.9 - Parâmetros de ajuste dos modelos matemáticos aos dados experimentais da curva de retenção com sucção matricial da amostra compactada para a trajetória de secagem.

\begin{tabular}{cccccccc}
\hline Parâmetros de Ajuste - van Genuchten (1980) & $\mathbf{w}_{\text {res }}(\boldsymbol{\%})$ & $\mathbf{w}_{\text {sat }}(\boldsymbol{\%})$ & $\boldsymbol{\alpha}$ & $\mathbf{n}$ & $\mathbf{m}$ & $\mathbf{r}^{\mathbf{2}}$ \\
\hline Am. Compactada Secagem & 15,8 & 43,7 & 6,781 & 0,6389 & 24,1738 & 0,98 \\
\hline Parâmetros de Ajuste - Fredlund \& Xing (1994) & $\mathbf{w}_{\text {res }}(\boldsymbol{\%})$ & $\mathbf{w}_{\text {sat }}(\boldsymbol{\%})$ & $\mathbf{a}$ & $\mathbf{n}$ & $\mathbf{m}$ & $\mathbf{r}^{\mathbf{2}}$ \\
\hline Am. Compactada Secagem & 15,8 & 43,7 & 99987,67 & 0,6307 & 206,6998 & 0,98 \\
\hline
\end{tabular}

Tabela 4.10 - Parâmetros de ajuste dos modelos matemáticos aos dados experimentais da curva de retenção com sucção matricial da amostra compactada para a trajetória de umedecimento.

\begin{tabular}{ccccccc}
\hline Parâmetros de Ajuste - van Genuchten (1980) & $\mathbf{w}_{\text {res }}(\boldsymbol{\%})$ & $\mathbf{w}_{\text {sat }}(\boldsymbol{\%})$ & $\boldsymbol{\alpha}$ & $\mathbf{n}$ & $\mathbf{m}$ & $\mathbf{r}^{\mathbf{2}}$ \\
\hline Am. Compactada Umedecimento & 5,7 & 33,0 & 3,859 & 0,6821 & 16,6525 & 0,99 \\
\hline Parâmetros de Ajuste - Fredlund \& Xing (1994) & $\mathbf{w}_{\text {res }}(\boldsymbol{\%})$ & $\mathbf{w}_{\text {sat }}(\boldsymbol{\%})$ & $\mathbf{a}$ & $\mathbf{n}$ & $\mathbf{m}$ & $\mathbf{r}^{\mathbf{2}}$ \\
\hline Am. Compactada Umedecimento & 5,7 & 33,0 & 999984,43 & 0,6711 & 104,7300 & 0,99 \\
\hline
\end{tabular}

As curvas de retenção determinadas em função da sucção matricial em trajetórias de umedecimento e secagem apresentaram histerese nas duas condições analisadas. A diferença de umidade entre as curvas de umedecimento e secagem é de aproximadamente $15 \%$ no 
trecho correspondente à entrada de ar, 2 a 3\% para a sucção de 10.000 kPa, e ao aproximar-se do trecho residual essa diferença tende a não existir. Este fato pode ser ocorrido visto que o material contém elevada porcentagem de finos, o qual apresenta alta sensibilidade em ciclos de umedecimento e secagem, o que pode levar a essa diferença na umidade de saturação.

No trecho residual, percebe-se que haveria necessidade de mais pontos para melhor configuração do final das curvas, possibilitando assim, a determinação das respectivas umidades residuais reais, tendo em vista que a mesma apresentou valor elevado de 15,8\% na trajetória de secagem. Os valores negativos apresentados na Tabela 4.7 e na Tabela 4.8 não tem função física, visto que, foram utilizados somente a título de ajuste dos modelos no software. Os modelos utilizados mostraram-se bem ajustados para essas curvas, com coeficientes de determinação $\left(\mathrm{r}^{2}\right)$ entre 0,98 e 0,99 .

As curvas de retenção realizadas pelo método do papel permitiram determinar o trecho correspondente à dessaturação do material, definindo o intervalo de sucção para ser imposto às amostras antes dos ensaios de expansão. Os níveis de sucção adotados para impor nas amostras variaram em um intervalo entre $40.000 \mathrm{kPa}$ e $5.000 \mathrm{kPa}$.

Foram realizadas tentativas para determinação da curva de retenção pelo método da câmara de pressão (Panela de Richards) para a amostra indeformada e amostra compactada, porém, ocorreram inúmeros problemas de queda de energia elétrica interrompendo o funcionamento do sistema de injeção de pressão de ar no equipamento. Por este fato, as curvas obtidas não apresentaram representatividade e consistência nos resultados experimentais. Dessa forma, optou-se por não utilizar esses dados, e manter somente a curva determinada pelo método do papel filtro como a curva característica de retenção do material.

\subsubsection{Dessecador a Vácuo}

As curvas de retenção pelo método do dessecador a vácuo foram determinadas para amostras na condição indeformada e compactada a partir de soluções salinas preparadas em concentrações correspondente aos intervalos de sucção de 40.000, 25.000, 10.000 e 5.000 $\mathrm{kPa}$. Esses ensaios foram realizados a fim de comparar o equilíbrio das sucções obtidas nas amostras destinadas aos ensaios de expansão. 


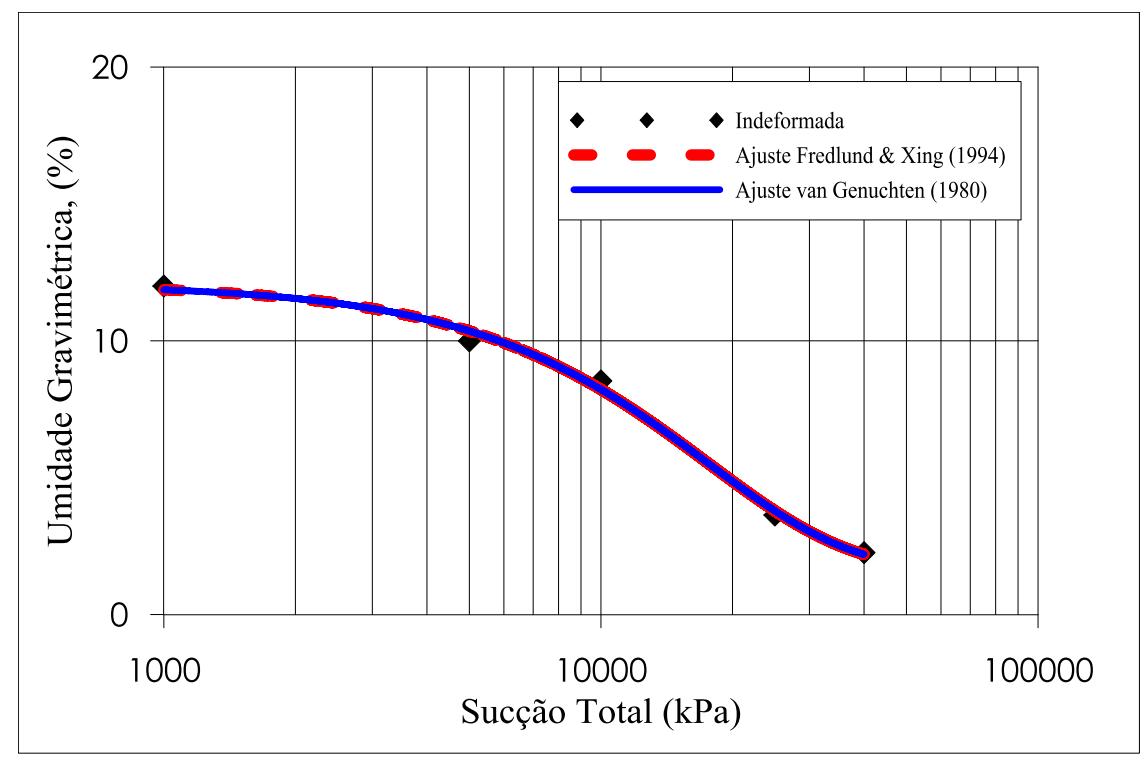

Figura 4.9 - Curva de retenção pelo método do dessecador a vácuo para amostra indeformada da Formação Corumbataí.

Os parâmetros de ajuste e os coeficientes de determinação $\left(\mathrm{r}^{2}\right)$ para a curva de retenção com sucção total na condição indeformada pelo método da câmara do dessecador a vácuo estão mostrados na Tabela 4.11.

Tabela 4.11 - Parâmetros de ajuste dos modelos matemáticos aos dados experimentais da curva de retenção com sucção total da amostra indeformada pelo método do dessecador a vácuo.

\begin{tabular}{ccccccc}
\hline Parâmetros de Ajuste - van Genuchten (1980) & $\mathbf{w}_{\mathbf{r}}(\boldsymbol{\%})$ & $\mathbf{w}_{\mathbf{s}}(\boldsymbol{\%})$ & $\boldsymbol{\alpha}$ & $\mathbf{n}$ & $\mathbf{m}$ & $\mathbf{r}^{\mathbf{2}}$ \\
\hline Am. Indeformada - Total & 1,7 & 12,1 & 3,4593 & 1,3630 & 45,4786 & 0,99 \\
\hline Parâmetros de Ajuste - Fredlund \& Xing (1994) & $\mathbf{w}_{\mathbf{r}}(\boldsymbol{\%})$ & $\mathbf{w}_{\mathbf{s}} \mathbf{( \% )}$ & $\mathbf{a}$ & $\mathbf{n}$ & $\mathbf{m}$ & $\mathbf{r}^{\mathbf{2}}$ \\
\hline Am. Indeformada - Total & 1,7 & 12,1 & 337617,64 & 1,3579 & 149,9859 & 0,99 \\
\hline
\end{tabular}




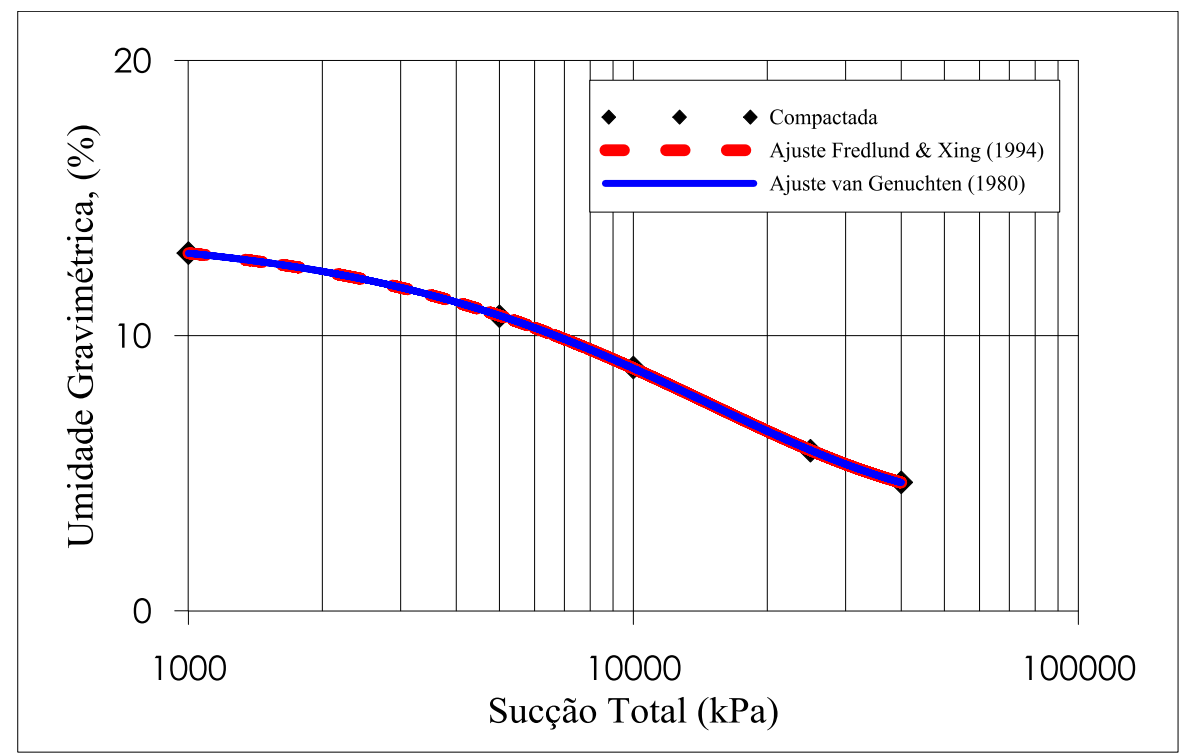

Figura 4.10 - Curva de retenção pelo método do dessecador a vácuo para amostra compactada da Formação Corumbataí.

Os parâmetros de ajuste e os coeficientes de determinação $\left(\mathrm{r}^{2}\right)$ para a curva de retenção com sucção total na condição compactada pelo método da câmara do dessecador a vácuo estão mostrados na Tabela 4.12.

Tabela 4.12 - Parâmetros de ajuste dos modelos matemáticos aos dados experimentais da curva de retenção com sucção total da amostra compactada pelo método do dessecador a vácuo.

\begin{tabular}{ccccccc}
\hline Parâmetros de Ajuste - van Genuchten (1980) & $\mathbf{w}_{\mathbf{r}}(\boldsymbol{\%})$ & $\mathbf{w}_{\mathbf{s}}(\boldsymbol{\%})$ & $\boldsymbol{\alpha}$ & $\mathbf{n}$ & $\mathbf{m}$ & $\mathbf{r}^{\mathbf{2}}$ \\
\hline Am. Compactada - Total & 3,7 & 13,8 & 3,2317 & 0,9252 & 16,5408 & 0,99 \\
\hline Parâmetros de Ajuste - Fredlund \& Xing (1994) & $\mathbf{w}_{\mathbf{r}}(\boldsymbol{\%})$ & $\mathbf{w}_{\mathbf{s}}(\boldsymbol{\%})$ & $\mathbf{a}$ & $\mathbf{n}$ & $\mathbf{m}$ & $\mathbf{r}^{\mathbf{2}}$ \\
\hline Am. Compactada - Total & 3,7 & 13,8 & 500000 & 0,9159 & 67,4761 & 0,99 \\
\hline
\end{tabular}

As curvas de retenção obtidas pelo dessecador a vácuo ficaram semelhantes às curvas obtidas pelo método do papel filtro, corroborando o intervalo de dessaturação adotado. O trecho correspondente ao intervalo entre as sucções escolhidas apresentou-se bem definido, o que facilitou o controle das sucções das amostras a serem ensaiadas. Como o ensaio é relativamente longo, e levando-se em consideração que as amostras a serem ensaiadas apresentavam maior dimensão, o tempo de equilíbrio das sucções foi significativamente maior. 


\subsection{Pressão de Expansão}

A pressão de expansão foi conduzida em amostras argilosas indeformadas e compactadas da Formação Corumbataí, e também em misturas desses materiais com bentonita. Foram realizados, também, ensaio de expansão em amostras arenosas da Formação Botucatu misturados com bentonita. O comportamento expansivo foi verificado por meio de ensaio na condição inundada e pela técnica da transferência de vapor.

\subsubsection{Ensaios de Expansão por Inundação}

\subsubsection{Amostra Indeformada da Formação Corumbataí}

Os ensaios por inundação em amostras da Formação Corumbataí foram conduzidos em amostras indeformadas com imposição da sucção inicial. As amostras foram moldadas a partir de blocos indeformados, com umidade natural, e posteriormente, estabilizadas nas condições iniciais de ensaio desejadas como mostra a Tabela 4.13. Os dados de moldagem estão mostrados na Tabela 4.14 .

Tabela 4.13 - Nomenclatura das amostras indeformadas da Formação Corumbataí.

\begin{tabular}{|c|c|}
\hline Nomenclatura & Condição das Amostras \\
\hline Seca ao ar & Amostra indeformada ensaiada na condição seca ao ar \\
\hline $40.000 \mathrm{kPa}$ & Amostra indeformada ensaiada com umidade estabilizada na sucção de $40.000 \mathrm{kPa}$ \\
\hline $25.000 \mathrm{kPa}$ & Amostra indeformada ensaiada com umidade estabilizada na sucção de $25.000 \mathrm{kPa}$ \\
\hline $10.000 \mathrm{kPa}$ & Amostra indeformada ensaiada com umidade estabilizada na sucção de $10.000 \mathrm{kPa}$ \\
\hline $5.000 \mathrm{kPa}$ & Amostra indeformada ensaiada com umidade estabilizada na sucção de $5.000 \mathrm{kPa}$ \\
\hline
\end{tabular}

Tabela 4.14 - Índices físicos de moldagem das amostras indeformadas da Formação Corumbataí.

\begin{tabular}{|c|c|c|c|c|c|c|c|}
\hline Amostra & $\begin{array}{c}\mathbf{w} \\
\mathbf{( \% )}\end{array}$ & $\begin{array}{c}\boldsymbol{\rho} \\
\mathbf{g} / \mathbf{c m}^{\mathbf{3}}\end{array}$ & $\begin{array}{c}\boldsymbol{\rho}_{\mathbf{d}} \\
\mathbf{g} / \mathbf{c m}^{\mathbf{3}}\end{array}$ & $\begin{array}{c}\boldsymbol{\rho}_{\mathbf{s}} \\
\mathbf{g} / \mathbf{c m}^{3}\end{array}$ & $\begin{array}{c}\mathbf{e} \\
-\end{array}$ & $\begin{array}{c}\mathbf{S r} \\
\mathbf{\%}\end{array}$ & $\begin{array}{c}\mathbf{n} \\
\mathbf{\%}\end{array}$ \\
\hline Seca ao ar & 26,64 & 1,75 & 1,38 & 2,69 & 0,95 & 48,73 & 75,43 \\
\hline $40.000 \mathrm{kPa}$ & 26,59 & 1,91 & 1,51 & 2,69 & 0,79 & 44,07 & 90,83 \\
\hline $25.000 \mathrm{kPa}$ & 24,31 & 1,77 & 1,42 & 2,69 & 0,87 & 46,50 & 75,27 \\
\hline $10.000 \mathrm{kPa}$ & 25,62 & 1,93 & 1,53 & 2,69 & 0,83 & 45,31 & 83,22 \\
\hline $5.000 \mathrm{kPa}$ & 24,31 & 1,79 & 1,41 & 2,69 & 0,85 & 45,91 & 77,07 \\
\hline
\end{tabular}

Após moldagem, a umidade inicial das amostras foi estabilizada em dessecadores a vácuo por meio de soluções salinas de $\mathrm{NaCl}$. Os índices físicos das amostras estão apresentados na Tabela 4.15. 
Tabela 4.15 - Índices físicos das amostras indeformadas da Formação Corumbataí antes do ensaio de expansão inundada.

\begin{tabular}{|c|c|c|c|c|c|c|c|}
\hline Amostra & $\begin{array}{c}\mathbf{w}_{\text {equilíbrio }} \\
(\mathbf{\%})\end{array}$ & $\begin{array}{c}\boldsymbol{\rho} \\
\mathbf{g} / \mathbf{c m}^{3}\end{array}$ & $\begin{array}{c}\mathbf{\rho}_{\mathbf{d}} \\
\mathbf{g} / \mathbf{c m}^{\mathbf{3}}\end{array}$ & $\begin{array}{c}\mathbf{\rho}_{\mathbf{s}} \\
\mathbf{g} / \mathbf{c m}^{\mathbf{3}}\end{array}$ & $\begin{array}{c}\mathbf{e} \\
-\end{array}$ & $\begin{array}{c}\mathbf{n} \\
\mathbf{\%}\end{array}$ & $\begin{array}{c}\mathbf{S r} \\
\mathbf{\%}\end{array}$ \\
\hline Seca ao ar & 3,65 & 1,74 & 1,68 & 2,69 & 0,60 & 37,68 & 16,24 \\
\hline $40.000 \mathrm{kPa}$ & 4,02 & 2,03 & 1,95 & 2,69 & 0,38 & 27,40 & 28,66 \\
\hline $25.000 \mathrm{kPa}$ & 4,47 & 2,06 & 1,97 & 2,69 & 0,37 & 26,81 & 32,83 \\
\hline $10.000 \mathrm{kPa}$ & 8,07 & 1,96 & 1,81 & 2,69 & 0,49 & 32,70 & 44,70 \\
\hline $5.000 \mathrm{kPa}$ & 12,19 & 1,90 & 1,70 & 2,69 & 0,59 & 36,91 & 56,08 \\
\hline
\end{tabular}

Os resultados dos ensaios de expansão inundada estão mostrados na Figura 4.11. É possível notar que as pressões máximas foram entre 300 e $800 \mathrm{kPa}$, sendo o aumento gradativo e proporcional ao aumento de sucção inicial das amostras.

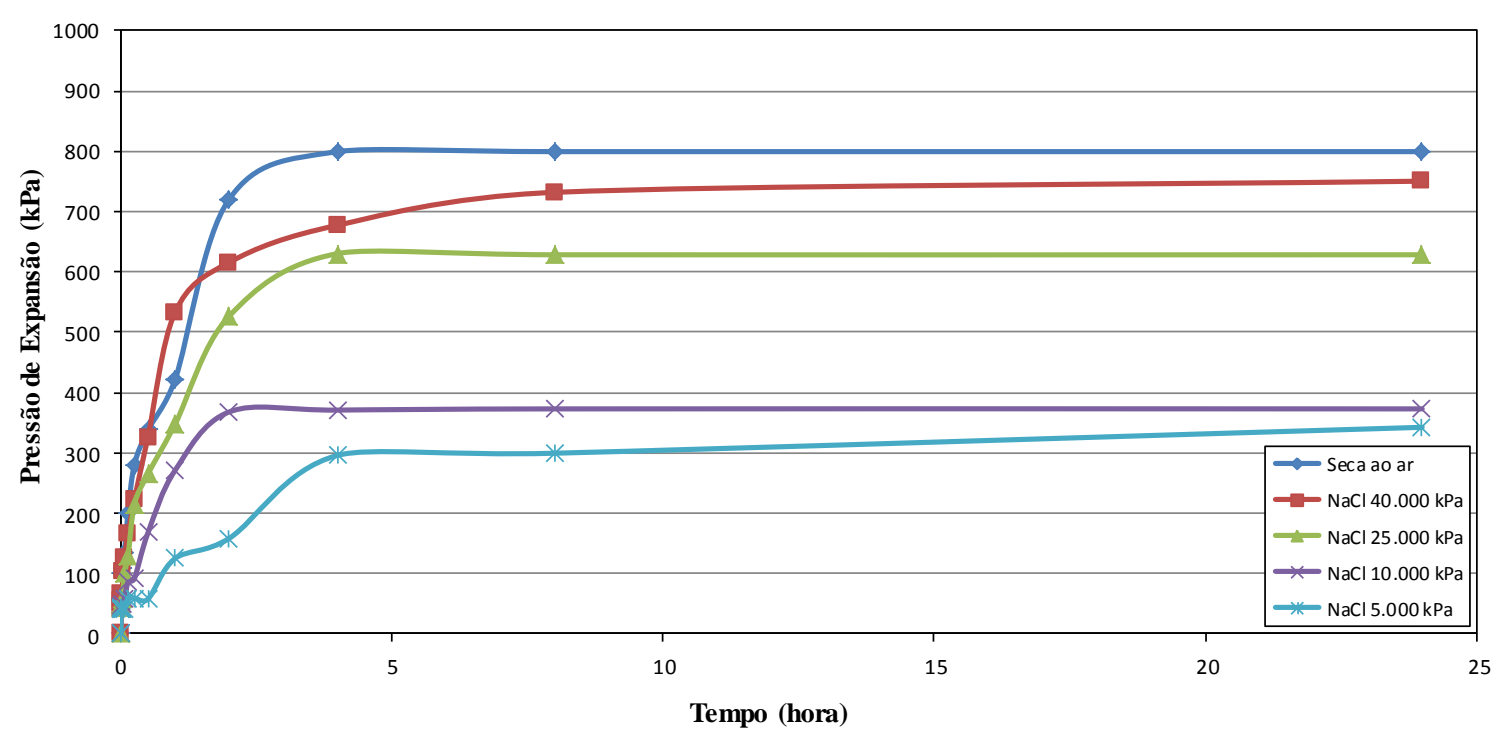

Figura 4.11 - Pressões de expansão inundada em amostras indeformadas da Formação Corumbataí.

As máximas pressões de expansão são apresentadas na Tabela 4.16, o que confirma a informação de que amostras com baixas sucções iniciais respondem com menores valores de expansão.

Tabela 4.16 - Pressões máximas de expansão inundada em amostras indeformadas da Formação Corumbataí.

\begin{tabular}{|c|c|}
\hline Ensaio & $\mathbf{P}_{\text {máxima }}(\mathbf{k P a})$ \\
\hline Seca ao ar & 799,15 \\
\hline $\mathrm{NaCl} 40.000 \mathrm{kPa}$ & 750,15 \\
\hline $\mathrm{NaCl} 25.000 \mathrm{kPa}$ & 628,15 \\
\hline $\mathrm{NaCl} 10.000 \mathrm{kPa}$ & 372,65 \\
\hline $\mathrm{NaCl} 5.000 \mathrm{kPa}$ & 342,15 \\
\hline
\end{tabular}




\subsubsection{Amostra Compactada da Formação Corumbataí}

Os ensaios por inundação em amostras compactadas da Formação Corumbataí são apresentados na Figura 4.12. Foram ensaiadas amostras nas condições: compactada na umidade ótima e, posteriormente, seca ao ar ( $\mathrm{W}_{\text {ót }}$ Seca ao Ar); compactada seca (pó) e, posteriormente, seca ao ar (Seca/ Seca ao Ar); compactada na umidade ótima e estabilizadas nas sucções de 40.000, 25.000, 10.000 e $5.000 \mathrm{kPa}$ (Tabela 4.17). As amostras compactadas na umidade ótima apresentaram índices físicos de moldagem mostrados na Tabela 4.18, com exceção da amostra compactada seca na forma de pó, cujas características de moldagem estão apresentadas na Tabela 4.19.

Tabela 4.17 - Nomenclatura das amostras indeformadas da Formação Corumbataí.

\begin{tabular}{|c|c|}
\hline Nomenclatura & Condição das Amostras \\
\hline Wot/ Seca ar & Amostra compactada na umidade ótima e ensaiada na condição seca ao ar \\
\hline Seca/ Seca ao ar & Amostra compactada seca na forma de pó e ensaiada na condição seca ao ar \\
\hline $40.000 \mathrm{kPa}$ & Amostra compactada na umidade ótima ensaiada com umidade estabilizada na sucção de 40.000 kPa \\
\hline $25.000 \mathrm{kPa}$ & Amostra compactada na umidade ótima ensaiada com umidade estabilizada na sucção de $25.000 \mathrm{kPa}$ \\
\hline $10.000 \mathrm{kPa}$ & Amostra compactada na umidade ótima ensaiada com umidade estabilizada na sucção de $10.000 \mathrm{kPa}$ \\
\hline $5.000 \mathrm{kPa}$ & Amostra compactada na umidade ótima ensaiada com umidade estabilizada na sucção de 5.000 kPa \\
\hline
\end{tabular}

Tabela 4.18 - Índices físicos de moldagem das amostras compactadas da Formação Corumbataí.

\begin{tabular}{|c|c|c|c|c|c|c|c|}
\hline Amostra & $\begin{array}{c}\mathbf{w} \\
\mathbf{( \% )}\end{array}$ & $\begin{array}{c}\boldsymbol{\rho} \\
\mathbf{g} / \mathbf{c m}^{3}\end{array}$ & $\begin{array}{c}\boldsymbol{\rho}_{\mathbf{d}} \\
\mathbf{g} / \mathbf{c m}^{\mathbf{3}}\end{array}$ & $\begin{array}{c}\boldsymbol{\rho}_{\mathbf{s}} \\
\mathbf{g} / \mathbf{c m}^{\mathbf{3}}\end{array}$ & $\begin{array}{c}\mathbf{e} \\
-\end{array}$ & $\begin{array}{c}\mathbf{n} \\
\mathbf{\%}\end{array}$ & $\begin{array}{c}\mathbf{S r} \\
\mathbf{\%}\end{array}$ \\
\hline Wot/Seca ar & 23,7 & 1,81 & 1,47 & 2,69 & 0,84 & 32,62 & 76,30 \\
\hline $40.000 \mathrm{kPa}$ & 23,7 & 1,81 & 1,47 & 2,69 & 0,84 & 32,64 & 76,26 \\
\hline $25.000 \mathrm{kPa}$ & 23,7 & 1,81 & 1,47 & 2,69 & 0,84 & 32,64 & 76,24 \\
\hline $10.000 \mathrm{kPa}$ & 23,7 & 1,81 & 1,47 & 2,69 & 0,84 & 32,60 & 76,36 \\
\hline $5.000 \mathrm{kPa}$ & 23,7 & 1,81 & 1,46 & 2,69 & 0,84 & 32,67 & 76,17 \\
\hline
\end{tabular}

Após moldagem, umidade inicial das amostras foi estabilizada em dessecadores a vácuo através de sucções impostas por soluções salinas de $\mathrm{NaCl}$. Os índices físicos das amostras estão apresentados na Tabela 4.19 .

Tabela 4.19 - Índices físicos das amostras compactadas da Formação Corumbataí.

\begin{tabular}{|c|c|c|c|c|c|c|c|}
\hline Amostra & $\begin{array}{c}\mathbf{w}_{\text {equilíbrio }} \\
(\boldsymbol{\%})\end{array}$ & $\begin{array}{c}\mathbf{\rho} \\
\mathbf{g} / \mathbf{c m}^{3}\end{array}$ & $\begin{array}{c}\mathbf{\rho}_{\mathbf{d}} \\
\mathbf{g} / \mathbf{c m}^{3}\end{array}$ & $\begin{array}{c}\mathbf{\rho}_{\mathbf{s}} \\
\mathbf{g} / \mathbf{c m}^{\mathbf{3}}\end{array}$ & $\begin{array}{c}\mathbf{e} \\
-\end{array}$ & $\begin{array}{c}\mathbf{n} \\
\mathbf{\%}\end{array}$ & $\begin{array}{c}\mathbf{S r} \\
\mathbf{\%}\end{array}$ \\
\hline Wot/Seca ar & 2,81 & 1,56 & 1,52 & 2,69 & 0,77 & 43,61 & 9,80 \\
\hline Seca/ Seca ao ar & 4,94 & 1,61 & 1,54 & 2,69 & 0,75 & 42,85 & 17,75 \\
\hline $40.000 \mathrm{kPa}$ & 4,99 & 1,64 & 1,56 & 2,69 & 0,72 & 41,96 & 18,56 \\
\hline $25.000 \mathrm{kPa}$ & 6,75 & 1,60 & 1,50 & 2,69 & 0,80 & 44,30 & 22,85 \\
\hline $10.000 \mathrm{kPa}$ & 9,35 & 1,70 & 1,56 & 2,69 & 0,73 & 42,10 & 34,58 \\
\hline $5.000 \mathrm{kPa}$ & 11,28 & 1,80 & 1,62 & 2,69 & 0,66 & 39,87 & 45,76 \\
\hline
\end{tabular}


Os resultados dos ensaios de expansão inundada das amostras compactadas estão mostrados na Figura 4.12. É possível notar que as pressões máximas foram entre 275 e $441 \mathrm{kPa}$, sendo o aumento gradativo e proporcional ao aumento de sucção inicial das amostras.

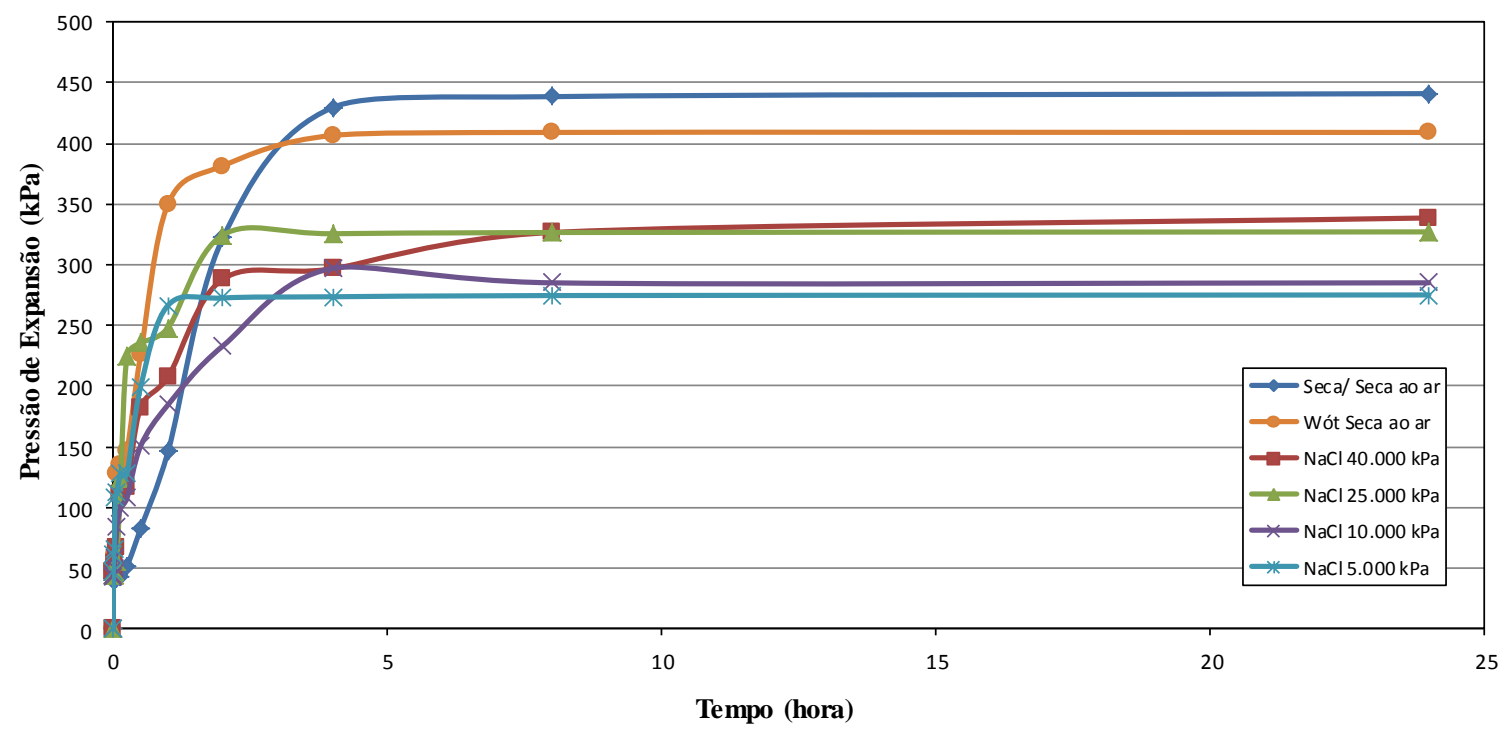

Figura 4.12 - Pressões de expansão em amostras compactadas da Formação Corumbataí.

As máximas pressões de expansão são apresentadas na Tabela 4.20, o que confirma a informação de que amostras com baixas sucções iniciais respondem com menores valores de expansão.

Tabela 4.20 - Pressões máximas de expansão inundada em amostras compactadas da Formação Corumbataí.

\begin{tabular}{|c|c|}
\hline Ensaio & $\mathbf{P}_{\text {máxima }}(\mathbf{k P a})$ \\
\hline Seca/ Seca ao ar & 441,15 \\
\hline Wot Seca ao ar & 409,15 \\
\hline $\mathrm{NaCl} 40.000 \mathrm{kPa}$ & 338,65 \\
\hline $\mathrm{NaCl} 25.000 \mathrm{kPa}$ & 327,15 \\
\hline $\mathrm{NaCl} 10.000 \mathrm{kPa}$ & 285,15 \\
\hline $\mathrm{NaCl} 5.000 \mathrm{kPa}$ & 275,15 \\
\hline
\end{tabular}

\subsubsection{Mistura de Material Argiloso da Formação Corumbataí com Bentonita}

As condições ensaiadas na inundação em misturas argilosas estão mostradas na Tabela 4.21. Os ensaios por inundação em amostras argilosas compactadas da Formação Corumbataí misturadas com bentonita são apresentados na Figura 4.13. A umidade inicial das amostras e os índices físicos estão apresentados na Tabela 4.22. Foram colocados nesta tabela, também, 
os dados da amostra compactada seca (na forma de pó) sem bentonita a título de comparação com as demais condições.

Tabela 4.21 - Nomenclatura das misturas argilosas da Formação Corumbataí com bentonita.

\begin{tabular}{|c|c|}
\hline Nomenclatura & Condição das Amostras \\
\hline Bentonita & Amostra de bentonita pura compactada na forma de pó e ensaiada na condição seca ao ar \\
\hline Argiloso $+70 \%$ Bent. & Mistura de material argiloso com 70\% bentonita pura compactada na forma de pó e ensaiada na condição seca ao ar \\
\hline Argiloso + 50\% Bent. & Mistura de material argiloso com 50\% bentonita pura compactada na forma de pó e ensaiada na condição seca ao ar \\
\hline Argiloso + 30\% Bent. & Mistura de material argiloso com 30\% bentonita pura compactada na forma de pó e ensaiada na condição seca ao ar \\
\hline Argiloso + 10\% Bent. & Mistura de material argiloso com 10\% bentonita pura compactada na forma de pó ensaiada na condição seca ao ar \\
\hline Argiloso + 5\% Bent. & Mistura de material argiloso com $5 \%$ bentonita pura compactada na forma de pó e ensaiada na condição seca ao ar \\
\hline Seca/ Seca ao Ar & Amostra compactada seca na forma de pó e ensaiada na condição seca ao ar \\
\hline
\end{tabular}

Tabela 4.22 - Índices físicos das amostras argilosas compactadas da Formação Corumbataí com bentonita.

\begin{tabular}{|c|c|c|c|c|c|c|c|}
\hline Amostra & $\begin{array}{c}\mathbf{w}_{\text {equilíbrio }} \\
(\boldsymbol{\%})\end{array}$ & $\begin{array}{c}\boldsymbol{\rho} \\
\mathbf{g} / \mathbf{c m}^{\mathbf{3}}\end{array}$ & $\begin{array}{c}\boldsymbol{\rho}_{\mathbf{d}} \\
\mathbf{g} / \mathbf{c m}^{\mathbf{3}}\end{array}$ & $\begin{array}{c}\boldsymbol{\rho}_{\mathbf{s}} \\
\mathbf{g} / \mathbf{c m}^{\mathbf{3}}\end{array}$ & $\begin{array}{c}\mathbf{e} \\
-\end{array}$ & $\begin{array}{c}\mathbf{n} \\
\mathbf{\%}\end{array}$ & $\begin{array}{c}\mathbf{S r} \\
\mathbf{\%}\end{array}$ \\
\hline Bentonita & 7,29 & 1,49 & 1,39 & 2,74 & 0,97 & 49,30 & 20,54 \\
\hline Argiloso + 70\% Bent. & 9,10 & 1,67 & 1,53 & 2,73 & 0,78 & 43,96 & 31,62 \\
\hline Argiloso + 50\% Bent. & 7,23 & 1,63 & 1,52 & 2,72 & 0,79 & 44,13 & 24,85 \\
\hline Argiloso + 30\% Bent. & 5,13 & 1,61 & 1,53 & 2,71 & 0,76 & 43,34 & 18,15 \\
\hline Argiloso + 10\% Bent. & 2,62 & 1,60 & 1,56 & 2,70 & 0,73 & 42,04 & 9,74 \\
\hline Argiloso + 5\% Bent. & 2,19 & 1,59 & 1,56 & 2,69 & 0,73 & 42,22 & 8,07 \\
\hline Seca/ Seca ao Ar & 4,94 & 1,74 & 1,66 & 2,69 & 0,63 & 38,50 & 21,24 \\
\hline
\end{tabular}

Os resultados dos ensaios de expansão inundada em amostras compactada estão mostrados na Figura 4.13. É possível notar que as pressões máximas variam entre $87 \mathrm{kPa}$ para o material com 5\% de adição de bentonita, e $700 \mathrm{kPa}$ para a bentonita pura.

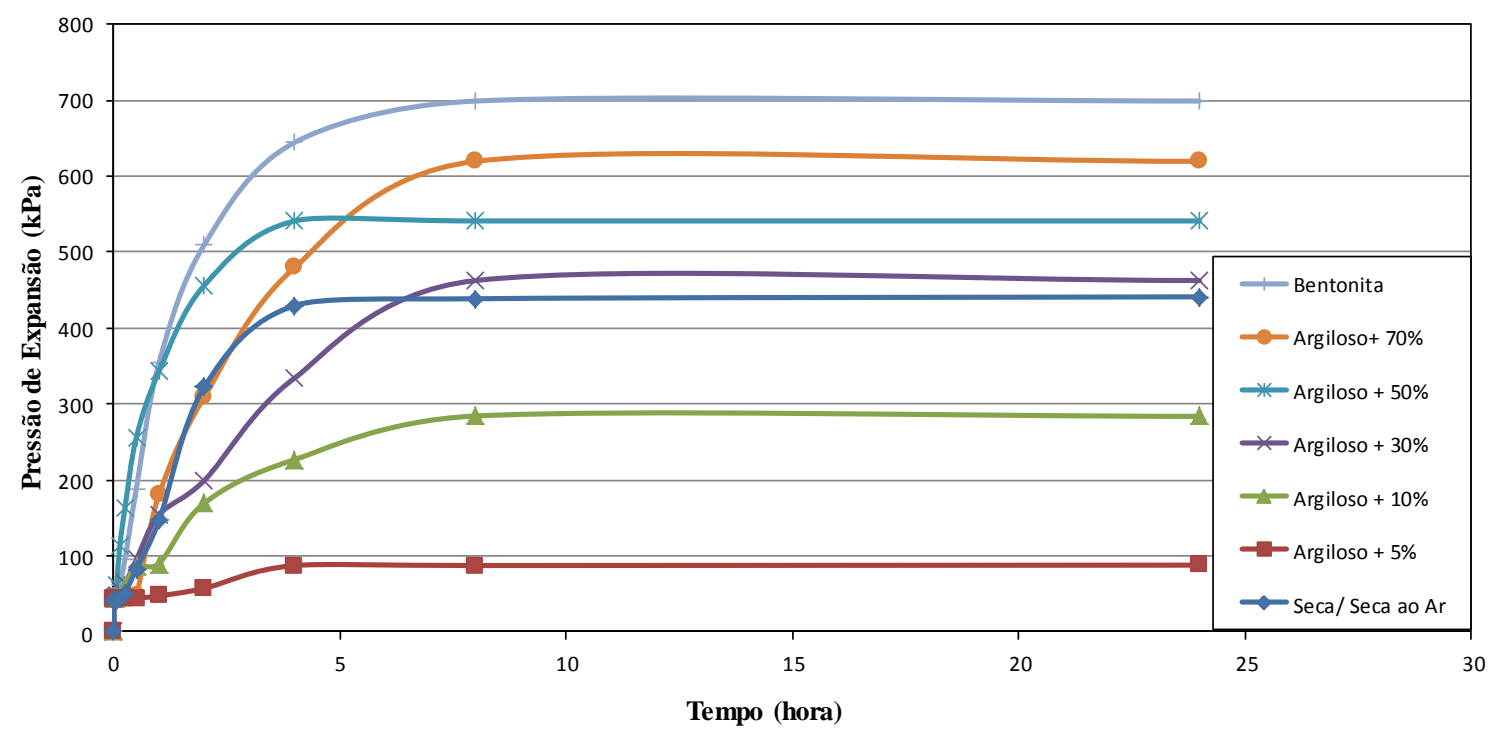

Figura 4.13 - Pressões de expansão inundada em amostras argilosas compactadas da Formação Corumbataí com bentonita. 
As máximas pressões de expansão são apresentadas na Tabela 4.23, o que confirma a informação de que amostras com baixo teor de argilomineral expansivo respondem com menores valores de expansão.

Tabela 4.23 - Pressões máximas de expansão inundada nas misturas de material argiloso compactado da Formação Corumbataí com bentonita.

\begin{tabular}{|c|c|}
\hline Ensaio & $\mathbf{P}_{\text {máxima }}(\mathbf{k P a})$ \\
\hline Bentonita & 699,15 \\
\hline Argiloso + 70\% Bent. & 619,65 \\
\hline Argiloso + 50\% Bent. & 541,15 \\
\hline Argiloso + 30\% Bent. & 462,65 \\
\hline Argiloso + 10\% Bent. & 283,65 \\
\hline Argiloso + 5\% Bent. & 87,65 \\
\hline Seca/ Seca ao Ar & 441,15 \\
\hline
\end{tabular}

A Tabela 4.24 apresenta as sucções iniciais das amostras antes do ensaio de expansão. Como não foram determinadas as curvas de retenção para as misturas analisadas nesta pesquisa, as sucções iniciais dessas amostras secas ao ar foram calculadas pela Lei de Kelvin como propõe Fredlund \& Rahardjo (1993) levando em consideração a umidade relativa do ar e temperatura do ambiente onde as amostras foram moldadas.

É possível notar que não houve uma uniformidade entre as condições iniciais de sucção, mesmo assim, os resultados demonstraram valores consistentes no que diz respeito ao aumento da pressão de expansão com o aumento no teor de bentonita da mistura.

Tabela 4.24 - Sucções iniciais das misturas de material da Formação Corumbataí com bentonita antes dos ensaios.

\begin{tabular}{|c|c|c|c|c|}
\hline Amostra & $\begin{array}{c}\text { Temperatura } \\
\mathbf{}^{\mathbf{C}}\end{array}$ & $\begin{array}{c}\text { Umidade } \\
\text { Relativa (\%) }\end{array}$ & Sucção (MPa)* & $\begin{array}{c}\mathbf{W}_{\text {equilíbrio }} \\
\mathbf{( \% )}\end{array}$ \\
\hline Bentonita & 20,0 & 53 & 86,0 & 7,29 \\
\hline Argiloso + 70\% Bent. & 23,9 & 39 & 129,2 & 9,10 \\
\hline Argiloso + 50\% Bent. & 25,4 & 42 & 119,6 & 7,23 \\
\hline Argiloso + 30\% Bent. & 26,2 & 40 & 126,7 & 5,13 \\
\hline Argiloso + 10\% Bent. & 26,2 & 57 & 77,7 & 2,62 \\
\hline Argiloso + 5\% Bent. & 25,7 & 64 & 61,6 & 2,10 \\
\hline Seca/ Seca ao Ar & 26,2 & 40 & 126,7 & 4,94 \\
\hline
\end{tabular}

*Sucção determinada com base na umidade relativa do ar antes da compactação.

\subsubsection{Mistura de Material Arenoso da Formação Botucatu com Bentonita}

As condições ensaiadas na inundação em misturas arenosas estão mostradas na Tabela 4.25.

Os resultados dos ensaios por inundação em amostras compactadas arenosas da Formação 
Botucatu misturadas com bentonita são apresentados na Figura 4.14. A umidade inicial das amostras e os índices físicos das estão apresentados na Tabela 4.26.

Tabela 4.25 - Nomenclatura das misturas arenosas da Formação Botucatu com bentonita.

\begin{tabular}{|c|l|}
\hline Nomenclatura & Condição das Amostras \\
\hline Arenoso + 70\% Bent. & Mistura de material arenoso com 70\% bentonita pura compactada na forma de pó e ensaiada na condição seca ao ar \\
\hline Arenoso + 50\% Bent. & Mistura de material arenoso com 50\% bentonita pura compactada na forma de pó e ensaiada na condição seca ao ar \\
\hline Arenoso + 30\% Bent. & Mistura de material arenoso com 30\% bentonita pura compactada na forma de pó e ensaiada na condição seca ao ar \\
\hline
\end{tabular}

Tabela 4.26 - Índices físicos das amostra arenosas compactadas da Formação Botucatu com bentonita antes do ensaio de expansão inundada.

\begin{tabular}{|c|c|c|c|c|c|c|c|}
\hline Amostra & $\begin{array}{c}\mathbf{w}_{\text {equilíbrio }} \\
(\boldsymbol{\%})\end{array}$ & $\begin{array}{c}\mathbf{\rho} \\
\mathbf{g} / \mathbf{c m}^{\mathbf{3}}\end{array}$ & $\begin{array}{c}\mathbf{\rho}_{\mathbf{d}} \\
\mathbf{g} / \mathbf{c m}^{\mathbf{3}}\end{array}$ & $\begin{array}{c}\mathbf{\rho}_{\mathbf{s}} \\
\mathbf{g} / \mathbf{c m}^{\mathbf{3}}\end{array}$ & $\begin{array}{c}\mathbf{e} \\
-\end{array}$ & $\begin{array}{c}\mathbf{n} \\
\mathbf{\%}\end{array}$ & $\begin{array}{c}\mathbf{S r} \\
\mathbf{\%}\end{array}$ \\
\hline Arenoso + 70\% Bent. & 6,39 & 1,60 & 1,51 & 2,71 & 0,80 & 44,34 & 21,70 \\
\hline Arenoso + 50\% Bent. & 4,61 & 1,75 & 1,67 & 2,68 & 0,60 & 37,59 & 20,54 \\
\hline Arenoso + 30\% Bent. & 2,82 & 1,81 & 1,76 & 2,68 & 0,52 & 34,28 & 14,51 \\
\hline
\end{tabular}

Na Figura 4.14 é possível notar que a expansão demonstrou valores consistentes no que diz respeito ao aumento no teor de bentonita da mistura.

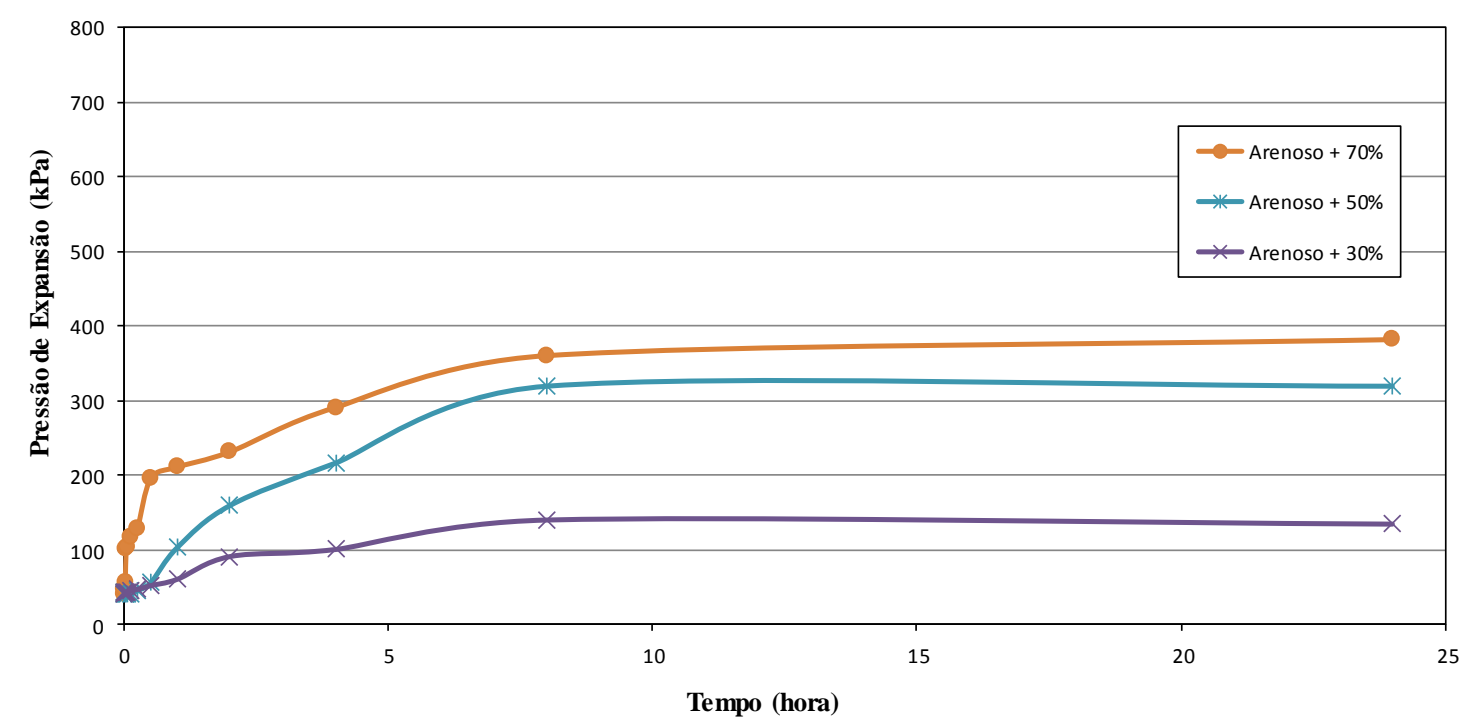

Figura 4.14 - Pressões de expansão inundada em amostras arenosas compactadas da Formação Botucatu com bentonita.

As máximas pressões de expansão são apresentadas na Tabela 4.27, o que corrobora o comportamento observado nas misturas de solo argiloso com bentonita. 
Tabela 4.27 - Pressões máximas de expansão inundada em amostras arenosas compactadas da Formação Botucatu com bentonita.

\begin{tabular}{|c|c|}
\hline Ensaio & $\mathbf{P}_{\text {máxima }}(\mathbf{k P a})$ \\
\hline Arenoso + 70\% Bent. & 381,65 \\
\hline Arenoso + 50\% Bent. & 319,15 \\
\hline Arenoso + 30\% Bent. & 134,15 \\
\hline
\end{tabular}

A Tabela 4.28 apresenta as sucções iniciais das amostras antes do ensaio de expansão calculadas da mesma forma como nas misturas de material argiloso com bentonita. Nota-se que a sucção inicial das amostras não apresentou valores tão elevados em comparação aos ensaios de material argiloso com bentonita. Mesmo assim, as expansões foram significativas.

Tabela 4.28 - Sucções iniciais das amostras arenosas compactadas da Formação Botucatu com bentonita antes dos ensaios

\begin{tabular}{|c|c|c|c|c|}
\hline Amostra & $\begin{array}{c}\text { Temperatura } \\
{ }^{\mathbf{o}} \mathbf{C}\end{array}$ & $\begin{array}{c}\text { Umidade } \\
\text { Relativa (\%) }\end{array}$ & Sucção (kPa)** & $\begin{array}{c}\mathbf{w}_{\text {equilíbrio }} \\
(\boldsymbol{\%})\end{array}$ \\
\hline Bentonita & 20 & 53 & 85970,49 & 7,29 \\
\hline Arenoso + 70\% Bent. & 26,5 & 62 & 66167,30 & 6,39 \\
\hline Arenoso + 50\% Bent. & 24,1 & 74 & 41343,65 & 4,61 \\
\hline Arenoso + 30\% Bent. & 24,0 & 74 & 41329,74 & 2,82 \\
\hline
\end{tabular}

*Sucção determinada com base na umidade relativa do ar antes da compactação.

\subsubsection{Ensaios de Expansão com Transferência de Vapor}

\subsubsection{Material Argiloso, Bentonita e Misturas}

Os resultados dos ensaios conduzidos com a técnica da transferência de vapor em amostras compactadas da Formação Corumbataí misturadas com bentonita estão mostrados na Figura 4.15. As amostras foram previamente secas ao ar, misturadas nas respectivas porcentagens desejadas e, em seguida, compactadas no anel de ensaio. Os índices físicos das amostras estão apresentados na Tabela 4.29.

Tabela 4.29 - Índices físicos das amostras argilosas compactadas da Formação Corumbataí misturadas com bentonita, antes do ensaio de expansão por transferência de vapor.

\begin{tabular}{|c|c|c|c|c|c|c|c|}
\hline Amostra & $\begin{array}{c}\mathbf{w}_{\text {equilíbrio }} \\
(\boldsymbol{\%})\end{array}$ & $\begin{array}{c}\mathbf{\rho} \\
\mathbf{g} / \mathbf{c m}^{\mathbf{3}}\end{array}$ & $\begin{array}{c}\mathbf{\rho}_{\mathbf{d}} \\
\mathbf{g} / \mathbf{c m}^{3}\end{array}$ & $\begin{array}{c}\mathbf{\rho}_{\mathbf{s}} \\
\mathbf{g} / \mathbf{c m}^{\mathbf{3}}\end{array}$ & $\begin{array}{c}\mathbf{e} \\
-\end{array}$ & $\begin{array}{c}\mathbf{n} \\
\mathbf{\%}\end{array}$ & $\begin{array}{c}\mathbf{S r} \\
\mathbf{\%}\end{array}$ \\
\hline Bentonita & 12,82 & 1,720 & 1,52 & 2,74 & 0,80 & 44,35 & 44,08 \\
\hline Argiloso + 70\% Bent. & 8,90 & 1,670 & 1,53 & 2,72 & 0,78 & 43,73 & 31,21 \\
\hline Argiloso + 50\% Bent. & 8,64 & 1,660 & 1,53 & 2,71 & 0,78 & 43,73 & 30,18 \\
\hline Argiloso + 30\% Bent. & 6,83 & 1,646 & 1,54 & 2,71 & 0,76 & 43,26 & 24,32 \\
\hline Argiloso + 10\% Bent. & 2,62 & 1,596 & 1,56 & 2,71 & 0,75 & 42,71 & 9,54 \\
\hline Argiloso + 5\% Bent. & 2,11 & 1,572 & 1,54 & 2,71 & 0,76 & 43,27 & 7,51 \\
\hline Seca/ Seca ao Ar & 1,52 & 1,605 & 1,58 & 2,69 & 0,70 & 41,21 & 5,83 \\
\hline
\end{tabular}


Durante todos os ensaios realizados com transferência de vapor foi imposto, apenas, um único nível de sucção às amostras, no valor de $5.000 \mathrm{kPa}$ por meio da solução salina de $\mathrm{NaCl}$, como descrito no item métodos. Este nível de sucção promoveu expansão frente à atmosfera de umedecimento, visto que, as amostras encontravam-se na condição seca com sucções mais elevadas.

A Figura 4.15 mostra as curvas de pressão de expansão versus o tempo de cada ensaio com a técnica da transferência de vapor. É possível notar que as pressões máximas foram entre 100 e $800 \mathrm{kPa}$, sendo o aumento gradativo e proporcional ao aumento da porcentagem de bentonita, como no ensaio inundado.

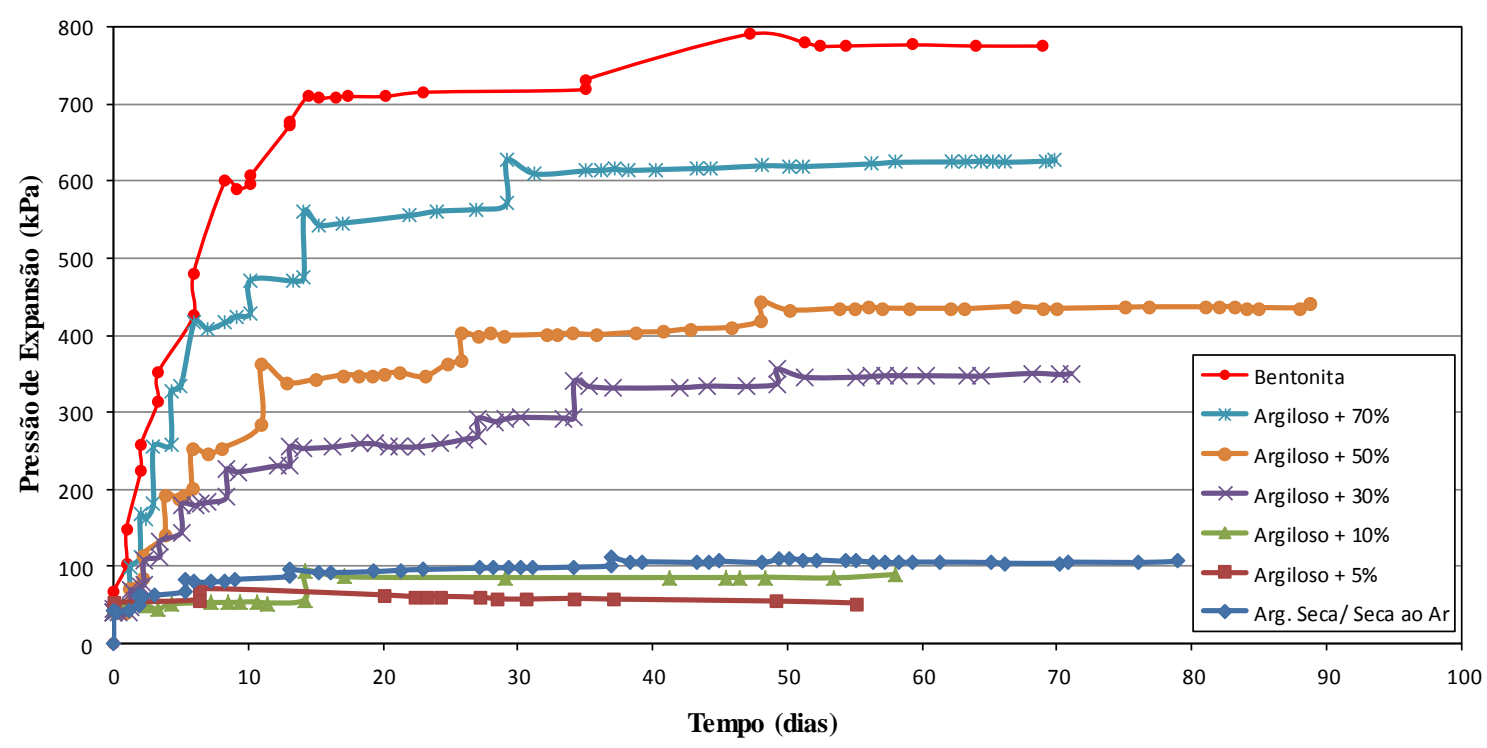

Figura 4.15 - Pressões de expansão com transferência de vapor em amostras argilosas compactadas da Formação Corumbataí misturadas com bentonita.

As máximas pressões de expansão são apresentadas na Tabela 4.30, o que confirma os resultados obtidos na expansão com inundação das amostras.

Tabela 4.30 - Pressões máximas de expansão por transferência de vapor em amostras argilosas compactadas da Formação Corumbataí misturadas com bentonita.

\begin{tabular}{|c|c|}
\hline Ensaio & $\mathbf{P}_{\text {máxima }}(\mathbf{k P a})$ \\
\hline Bentonita & 777,15 \\
\hline Argiloso + 70\% Bent. & 627,15 \\
\hline Argiloso + 50\% Bent. & 441,65 \\
\hline Argiloso + 30\% Bent. & 356,15 \\
\hline Argiloso + 10\% Bent. & 94,65 \\
\hline Argiloso + 5\% Bent. & 71,15 \\
\hline Seca/ Seca ao Ar & 109,65 \\
\hline
\end{tabular}


A Tabela 4.31 apresenta as sucções iniciais das amostras antes do ensaio de expansão por transferência de vapor calculadas, também, pela Lei de Kelvin como propõe Fredlund e Rahardjo (1993). É possível notar que não houve uma uniformidade entre as condições iniciais de sucção, mesmo assim, os resultados demonstraram valores consistentes no que diz respeito ao aumento da pressão de expansão com o aumento no teor de bentonita da mistura.

Tabela 4.31 - Sucções iniciais antes dos ensaios das amostras argilosas compactadas da Formação Corumbataí misturadas com bentonita.

\begin{tabular}{|c|c|c|c|c|}
\hline Amostra & $\begin{array}{c}\text { Tempe ratura } \\
{ }^{\mathbf{}} \mathbf{C}\end{array}$ & $\begin{array}{c}\text { Umidade } \\
\text { Relativa (\%) }\end{array}$ & Sucção (MPa)** & $\begin{array}{c}\mathbf{w}_{\text {equilibrio }} \\
(\mathbf{\%})\end{array}$ \\
\hline Bentonita & 24,4 & 57,3 & 76,5 & 12,82 \\
\hline Argiloso + 70\% Bent. & 22,8 & 61,0 & 67,6 & 8,90 \\
\hline Argiloso + 50\% Bent. & 23,3 & 70,0 & 48,8 & 8,64 \\
\hline Argiloso + 30\% Bent. & 23,5 & 58,0 & 74,6 & 6,83 \\
\hline Argiloso + 10\% Bent. & 26,2 & 57,0 & 77,7 & 2,62 \\
\hline Argiloso + 5\% Bent. & 25,7 & 39,0 & 130,0 & 2,11 \\
\hline Seca/ Seca ao Ar & 21,0 & 74,0 & 40,9 & 1,52 \\
\hline
\end{tabular}

*Sucção determinada com base na umidade relativa antes da compactação.

\subsubsection{Misturas de Material Arenoso com Bentonita}

Os resultados dos ensaios conduzidos com a técnica da transferência de vapor em amostras de arenosas compactadas da Formação Botucatu misturados com bentonita são mostrados na Figura 4.16. As amostras foram previamente secas ao ar, misturadas nas respectivas porcentagens desejadas, e em seguida compactadas no cilíndro de ensaio. Os índices físicos das amostras estão apresentados na Tabela 4.32.

Tabela 4.32 - Índices físicos das amostras arenosas compactadas da Formação Botucatu misturadas com bentonita antes do ensaio de expansão por transferência de vapor.

\begin{tabular}{|c|c|c|c|c|c|c|c|}
\hline Amostra & $\begin{array}{c}\mathbf{w}_{\text {equilíbrio }} \\
(\mathbf{\%})\end{array}$ & $\begin{array}{c}\mathbf{\rho} \\
\mathbf{g} / \mathbf{c m}^{\mathbf{3}}\end{array}$ & $\begin{array}{c}\mathbf{\rho}_{\mathbf{d}} \\
\mathbf{g} / \mathbf{c m}^{\mathbf{3}}\end{array}$ & $\begin{array}{c}\mathbf{\rho}_{\mathbf{s}} \\
\mathbf{g} / \mathbf{c m}^{\mathbf{3}}\end{array}$ & $\begin{array}{c}\mathbf{e} \\
-\end{array}$ & $\begin{array}{c}\mathbf{n} \\
\mathbf{\%}\end{array}$ & $\begin{array}{c}\mathbf{S r} \\
\mathbf{\%}\end{array}$ \\
\hline Arenoso + 70\% Bent. & 8,48 & 1,90 & 1,75 & 2,71 & 0,55 & 35,33 & 42,00 \\
\hline Arenoso + 50\% Bent. & 6,25 & 1,75 & 1,65 & 2,68 & 0,63 & 38,49 & 26,81 \\
\hline Arenoso + 30\% Bent. & 3,72 & 1,79 & 1,73 & 2,66 & 0,54 & 35,02 & 18,37 \\
\hline
\end{tabular}

A Figura 4.16 mostra as curvas de pressão de expansão versus o tempo de cada ensaio para as misturas de material arenoso com bentonita utilizando a técnica da transferência de vapor, sob sucção imposta de $5.000 \mathrm{kPa}$. Nota-se, também, que as pressões máximas foram entre $93 \mathrm{e}$ $440 \mathrm{kPa}$, resultando do aumento gradativo e proporcional ao aumento da porcentagem de bentonita, como no ensaio inundado. 


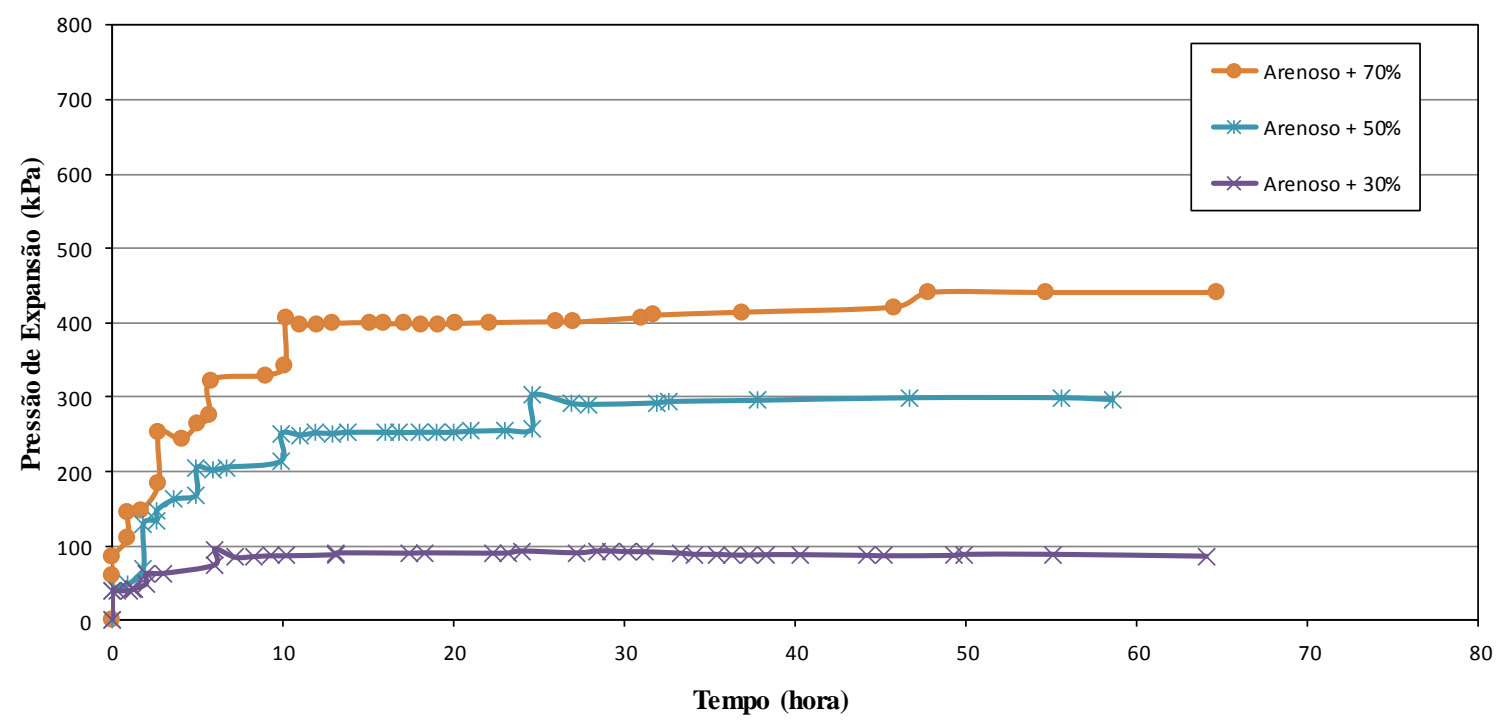

Figura 4.16 - Pressões de expansão com transferência de vapor em amostras arenosas compactadas da Formação Botucatu misturadas com bentonita.

As máximas pressões de expansão são apresentadas na Tabela 4.33, o que confirma o comportamento expansivo da bentonita com material não expansivo. $\mathrm{O}$ aumento da expansão, também, é gradativo com o aumento da porcentagem de material.

Tabela 4.33 - Pressões máximas de expansão por transferência de vapor em amostras arenosas compactadas da Formação Botucatu misturadas com bentonita.

\begin{tabular}{|c|c|}
\hline Ensaio & $\mathbf{P}_{\text {máxima }}(\mathbf{k P a})$ \\
\hline Arenoso + 70\% Bent. & 440,65 \\
\hline Arenoso + 50\% Bent. & 299,15 \\
\hline Arenoso + 30\% Bent. & 93,15 \\
\hline
\end{tabular}

A Tabela 4.34 apresenta as sucções iniciais das amostras antes do ensaio de expansão por transferência de vapor calculadas da mesma forma como nas misturas de material argiloso com bentonita. É possível notar que não houve uma uniformidade entre as condições iniciais de sucção, mesmo assim, os resultados demonstraram valores consistentes no que diz respeito ao aumento da pressão de expansão com o aumento no teor de bentonita da mistura. 
Tabela 4.34 - Sucções iniciais antes dos ensaios das amostras compactadas arenosas da Formação Botucatu misturadas com bentonita.

\begin{tabular}{|c|c|c|c|c|}
\hline Amostra & $\begin{array}{c}\text { Temperatura } \\
{ }^{\mathbf{C}}\end{array}$ & $\begin{array}{c}\text { Umidade } \\
\text { Relativa (\%) }\end{array}$ & Sucção (MPa)* & $\begin{array}{c}\mathbf{W}_{\text {equilíbrio }} \\
(\%)\end{array}$ \\
\hline Arenoso + 70\% Bent. & 23 & 56,0 & 79,3 & 8,48 \\
\hline Arenoso + 50\% Bent. & 23 & 55,2 & 81,3 & 6,25 \\
\hline Arenoso + 30\% Bent. & 23 & 71,0 & 46,9 & 3,72 \\
\hline
\end{tabular}

*Sucção determinada com base na umidade relativa ambiente antes da compactação.

Após os ensaios com a técnica da transferência de vapor, as amostras foram submetidas à inundação para avaliar se a expansão máxima de todas as condições analisadas nesta pesquisa já haviam sido mobilizadas. Dessa forma, não foi possível determinar as umidades finais após a transferência de vapor, visto que, os corpos de prova não foram desmontados da célula edométrica. 


\section{ANÁLISE DOS RESULTADOS}

\subsection{Ensaios de Expansão Inundada}

\subsubsection{Comportamento das Amostras Indeformadas e Compactadas da Formação Corumbataí}

As pressões máximas de expansão foram obtidas nos ensaios inundados em amostras indeformadas com umidade estabilizada no dessecador a vácuo, e seca ao ar. A máxima pressão apresentou valores da ordem de $800 \mathrm{kPa}$ para a amostra indeformada na condição seca ao ar. Para as amostras compactadas após secagem ao ar, com respectivas umidades estabilizadas, a máxima pressão de expansão foi obtida, para a amostra compactada seca na forma de pó, e posteriormente seca ao ar, com valor na ordem de $440 \mathrm{kPa}$. Essa diferença entre as máximas pressões de expansão entre as amostras indeformadas e compactadas pode ser explicada pela condição inicial das mesmas, envolvendo os índices físicos dos corpos de provas ensaiados, bem como, a sucção inicial. A Tabela 5.1 apresenta esses dados para as duas situações, e a Tabela 5.2 apresenta os índices físicos das amostras.

Tabela 5.1 - Características dos ensaios de máxima pressão de expansão.

\begin{tabular}{|c|c|c|c|}
\hline Amostra & Pmáx (kPa) & Condição & Sucção Inicial (MPa) \\
\hline Indeformada & 799,15 & Seca ao $\mathrm{Ar}$ & 77,1 \\
\hline Compactada & 441,15 & Seca/ Seca ao $\mathrm{Ar}$ & 89,4 \\
\hline
\end{tabular}

Tabela 5.2 - Índices físicos das amostras de máxima expansão.

\begin{tabular}{|c|c|c|c|c|}
\hline Amostra & Condição & $\mathbf{\rho}_{\mathbf{d}}\left(\mathbf{g} / \mathbf{c m}^{\mathbf{3}}\right)$ & $\mathbf{e}$ & $\mathbf{S r}(\boldsymbol{\%})$ \\
\hline Indeformada & Seca ao ar & 1,67 & 0,60 & 16,4 \\
\hline Compactada & Seca/ Seca ao ar & 1,52 & 0,77 & 9,8 \\
\hline
\end{tabular}

A Tabela 5.2 mostra que os índices físicos entre as amostras diferem significativamente no grau de saturação. A densidade seca apresenta-se maior nas amostras indeformadas, porém com maior teor de água nos vazios por conta do grau de saturação, e nas amostras compactadas apresenta-se com menor densidade e menos água nos vazios. Ou seja, a expansão da amostra indeformada foi governada pela densidade aparente seca e pelo índice de vazios.

Neste caso, pode-se inferir que os $16,4 \%$ de saturação nos vazios permitiu a formação de meniscos capilares entre as partículas aumentando a capacidade de absorção de água pela 
matriz do solo. Essa água já incorporada nos vazios das amostras antes do ensaio de expansão, serviu de canais de alimentação aos demais poros ao seu redor quando se deu o processo de inundação nas faces superior e inferior dos corpos de prova.

As amostras estabilizadas nas sucções de 5.000 e $10.000 \mathrm{kPa}$ não apresentaram aumento significativo nas pressões de expansão, tanto para as amostras indeformadas como para as amostras compactadas. Neste caso, pode-se atribuir que a sucção inicial não teve influência significativa.

Os gráficos apresentados nas Figura 4.11 e Figura 4.12 mostram para as amostras indeformadas que a mobilização da expansão ocorre de forma mais rápida para as amostras estabilizadas em 10.000 e $40.000 \mathrm{kPa}$, enquanto que nas compactadas ocorre na amostras compactada na umidade ótima, e depois na compactada seca com cerca de 1 hora de diferença na mobilização da expansão.

A Figura 5.1 apresenta o gráfico da relação entre a pressão máxima de expansão e a sucção inicial das amostras indeformadas e compactadas nos ensaios inundados. Fica claro que valores elevados de sucção tem maior influência na expansão do material natural. As amostras compactadas na umidade ótima e estabilizadas no dessecador a vácuo não demonstraram valores de expansão expressivos em relação aos níveis de sucção. Este fato pode ter ocorrido devido à compactação das amostras ter sido na umidade ótima. Neste caso, haveria possibilidade de mudança se fossem compactadas secas e em seguidas colocadas no dessecador para estabilização na sucção desejada.

A linha de tendência para as pressões máximas das amostras indeformadas apresentou como melhor ajuste uma equação polinomial do segundo grau com coeficiente angular próximo de zero. Enquanto que nas compactadas, o ajuste linear mostrou melhor comportamento. 


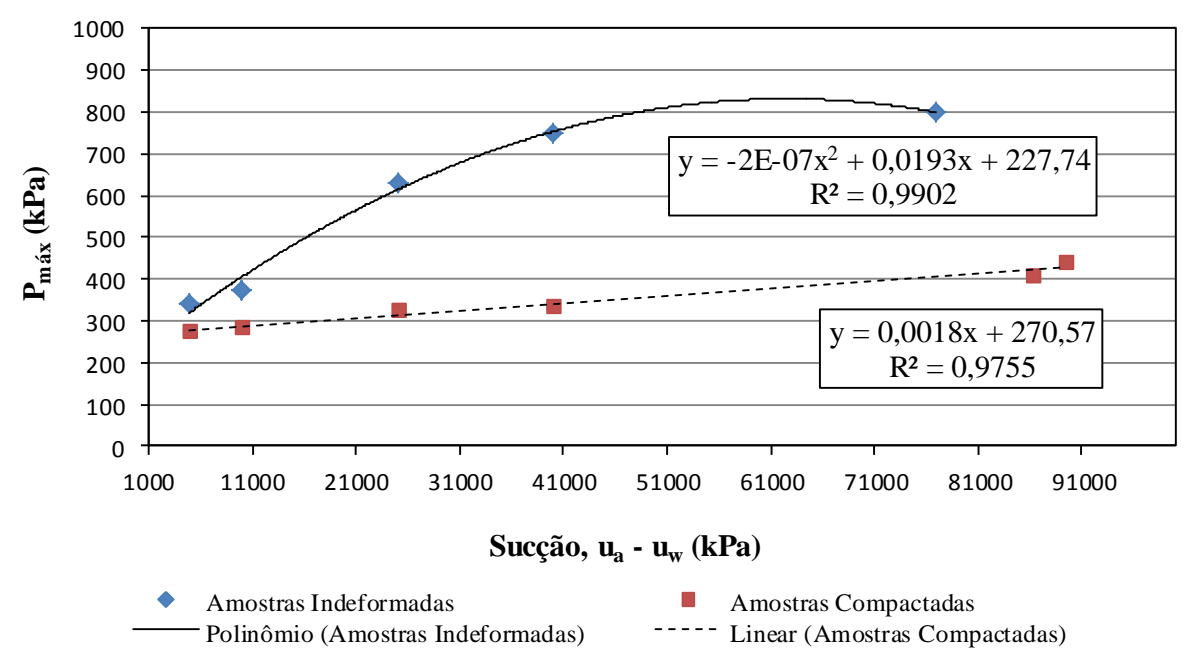

Figura 5.1 - Pressão de expansão versus sucção das amostras indeformadas e compactadas da Formação Corumbataí.

Nota-se na Figura 5.1 que os dados experimentais das amostras indeformadas não permitiram uma correlação linear devido ao último ponto do gráfico, correspondente à amostra indeformada seca ao ar. A sucção dessa amostra foi calculada com base na umidade relativa do ar da sala de ensaio e, portanto, esse valor pode não oferecer boa precisão. Assim sendo, se não for considerado este ponto, é possível que se obtenha, também, uma correlação linear para as amostras indeformadas. Vale ressaltar, ainda, que a correlação obtida nas amostras compactadas é válida apenas para o intervalo de sucção estudado.

\subsubsection{Distribuição de Poros - Amostras Indeformadas}

Existe uma divisão nítida entre os tamanhos de poros dos materiais estudados. De maneira geral, essa separação corresponde a dois grandes grupos, sendo os poros de tamanho grande e os poros de tamanho pequeno. Como visto da revisão bibliográfica desta pesquisa, esses grupos são dividos em duas classes: macroporos e microporos. A porosimetria por intrusão de mercúrio (PIM) foi realizada em todas as amostras desta pesquisa para determinar a respectiva macro e microporosidade existente nos materiais.

Nas amostras indeformadas, as análises de PIM foram realizadas antes e após o ensaio de expansão. A Figura 5.2 apresenta os resultados da amostra indeformada seca ao ar, a Figura 5.3 os dados da amostra indeformada com umidade estabilizada na solução salina de $\mathrm{NaCl}$ de $40.000 \mathrm{kPa}$, a Figura 5.4 os dados da amostra indeformada com umidade estabilizada na solução salina de $\mathrm{NaCl}$ de $25.000 \mathrm{kPa}$, a Figura 5.5 os dados da amostra indeformada com 
umidade estabilizada na solução salina de $\mathrm{NaCl}$ de $10.000 \mathrm{kPa}$, e a a Figura 5.6 os dados da amostra indeformada com umidade estabilizada na solução salina de $\mathrm{NaCl}$ de $5.000 \mathrm{kPa}$.

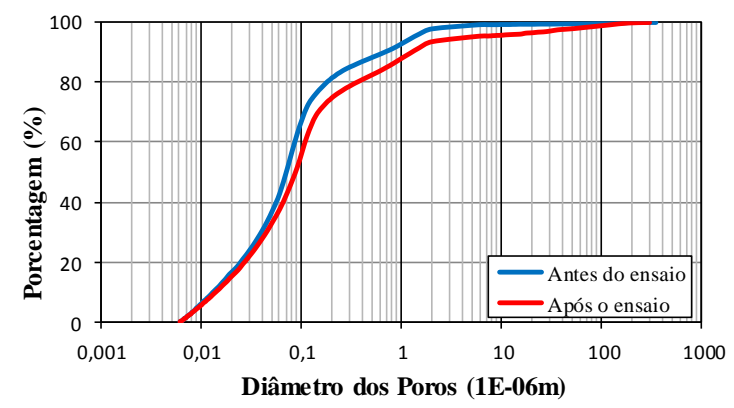

(a)

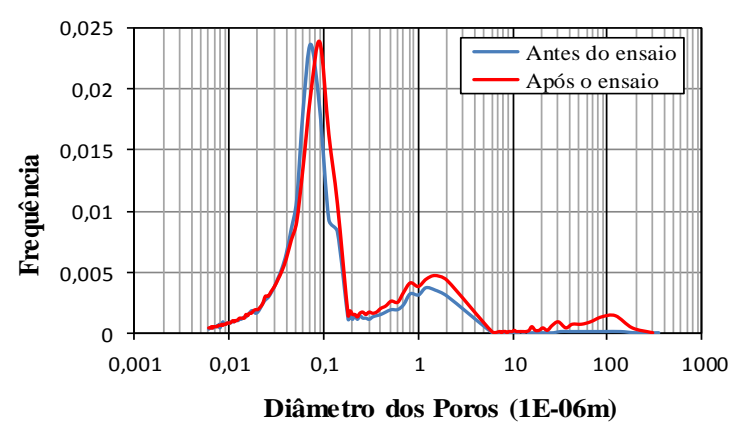

(b)

Figura 5.2 - Porosimetria por intrusão de mercúrio para amostra indeformada na condição seca ao ar: (a) Porcentagem versus diâmetro dos poros; (b) Frequência dos intervalos de diâmetros.

O ensaio com amostras indeformadas seca ao ar na qual revelou máxima pressão de expansão apresentou pequeno aumento na frequência de microporos após o ensaio (Figura 5.2). Após a expansão, houve a formação de dois intervalos de macroporo com frequências máximas em torno de $1 \mu \mathrm{m}$ e $10 \mu \mathrm{m}$, onde esse intervalo intermediário pode ser considerado um "mesoporo".

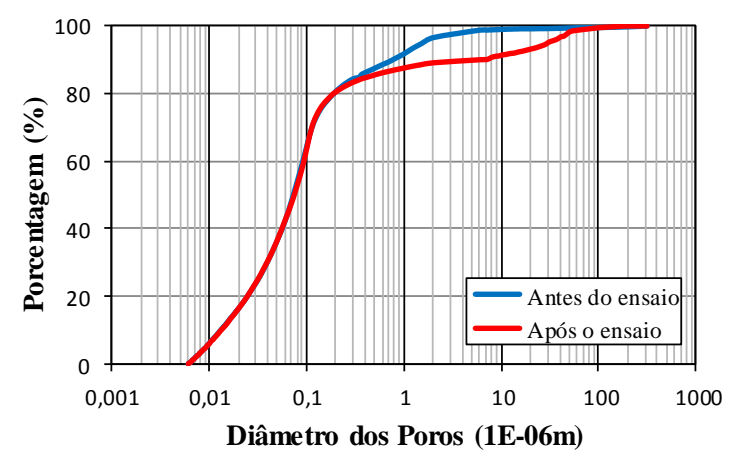

(a)

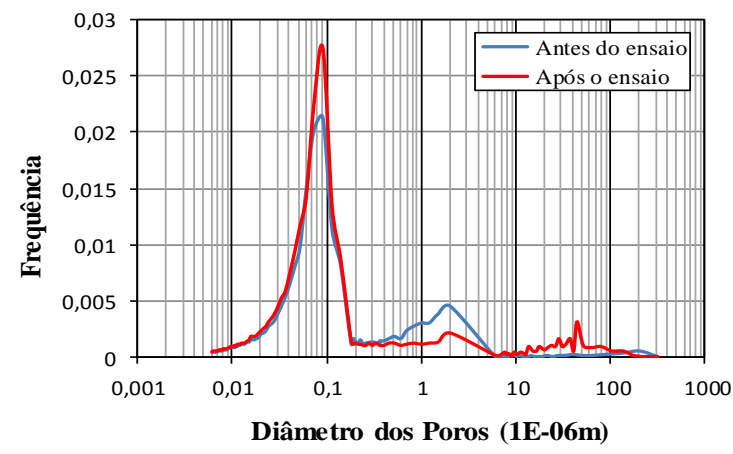

(b)

Figura 5.3 - Porosimetria por intrusão de mercúrio para amostra indeformada com umidade estabilizada na sucção de $40.000 \mathrm{kPa}$ : (a) Porcentagem versus diâmetro dos poros; (b)

Frequência dos intervalos de diâmetros.

Como mostra a Figura 5.3, a amostra estabilizada na sucção de $40.000 \mathrm{kPa}$ apresentou um comportamento distinto dos outros ensaios, com aumento na frequência dos microporos. Este fato pode ser esclarecido a partir da formação de macroporos de tamanhos maiores comprimindo os microporos ao seu redor, e em consequência disso aumentou a frequência dos microporos. 


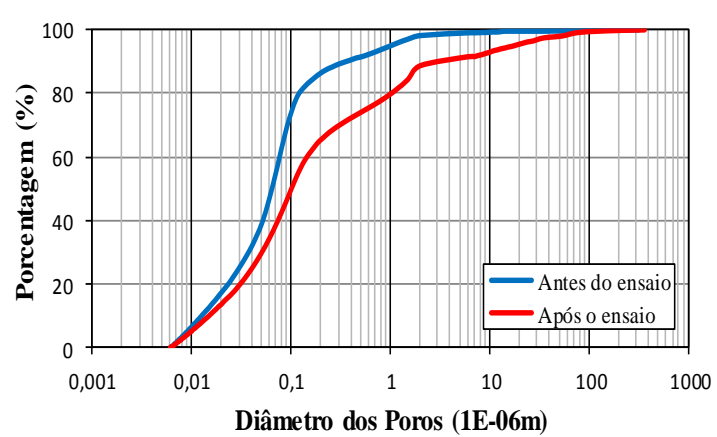

(a)

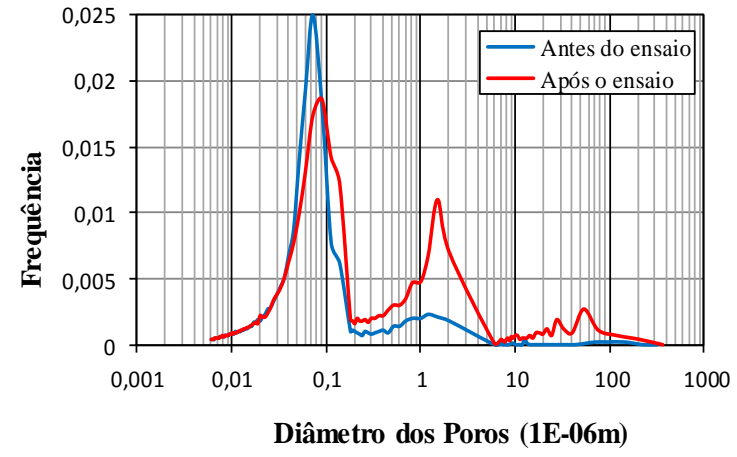

(b)

Figura 5.4 - Porosimetria por intrusão de mercúrio para a mostra indeformada com umidade estabilizada na sucção de 25.000 kPa: (a) Porcentagem versus diâmetro dos poros; (b) Frequência dos intervalos de diâmetros.

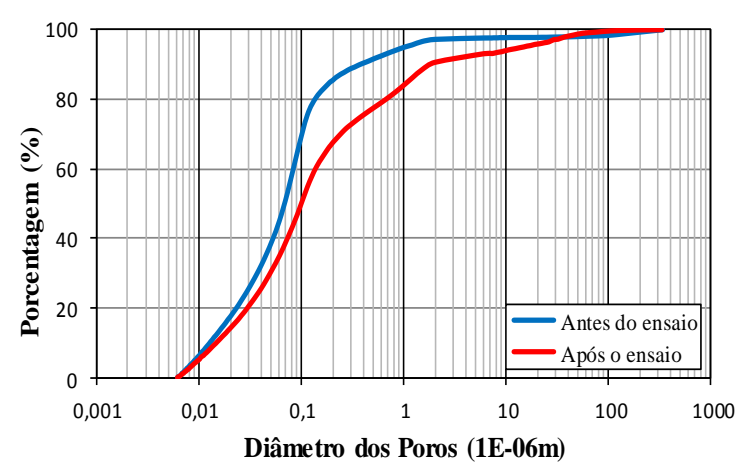

(a)

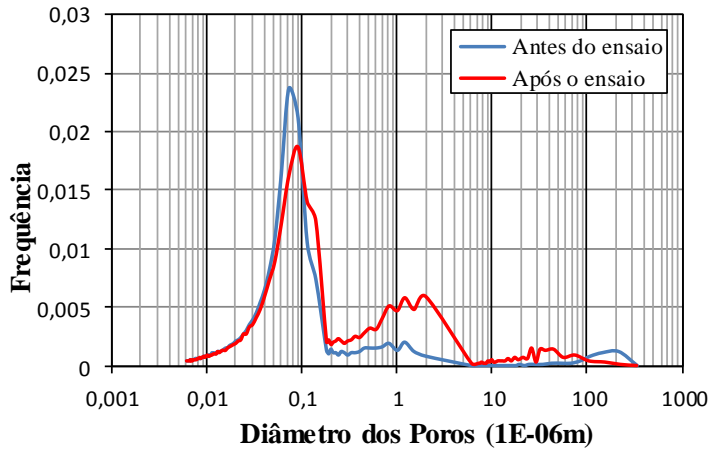

(b)

Figura 5.5 - Porosimetria por intrusão de mercúrio para amostra indeformada com umidade estabilizada na sucção de 10.000 kPa: (a) Porcentagem versus diâmetro dos poros; (b) Frequência dos intervalos de diâmetros.

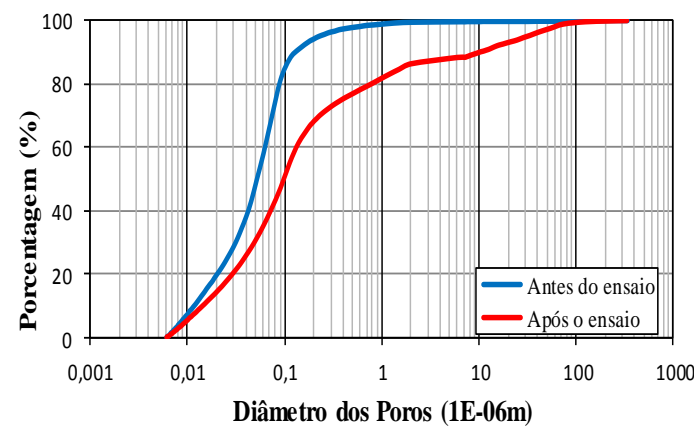

(a)

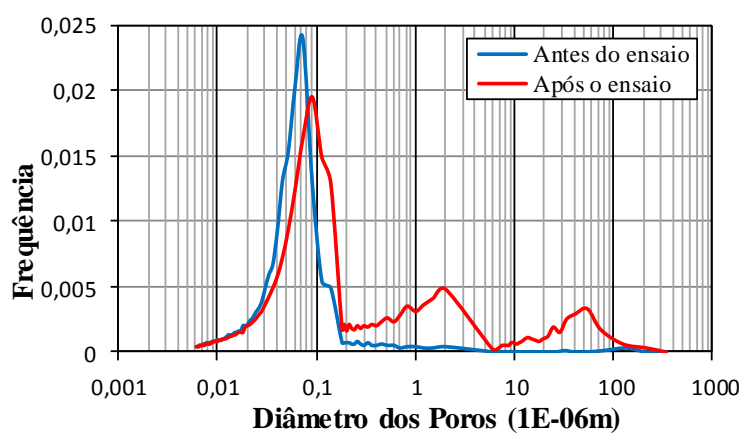

(b)

Figura 5.6 - Porosimetria por intrusão de mercúrio para amostra indeformada com umidade estabilizada na sucção de $5.000 \mathrm{kPa}$ : (a) Porcentagem versus diâmetro dos poros; (b) Frequência dos intervalos de diâmetros.

Nos ensaios com sucção estabilizada em 25.000 e 10.000 houve redução significativa na frequência de microporos, e um arranjo irregular nos intervalos de macroporo, com tendência a formação de macroporos de novos tamanhos (Figura 5.5 e Figura 5.6). Já no ensaio com 
sucção estabilizada em $5.000 \mathrm{kPa}$, o comportamento dos macroporos após o ensaio foi semelhante ao que ocorreu com o ensaio realizado na amostra seca ao ar.

É possível notar em todas as amostras que o intervalo de microporo encontra-se em $0,1 \mu \mathrm{m}$, porém, o intervalo de macroporo varia de acordo com a condição da amostra. O predomínio é de poros menores nas amostras indeformadas.

Diversos autores na literatura sugeriram classificações de tamanho de poros para diferentes tipos de materiais. Como não há um consenso para a aplicação dessas classificações em solos, optou-se por utilizar uma classificação recomendada pela International Union Of Pure and Applied Chemistry (IUPAC). A divisão do tamanho de poros proposta pela IUPAC é aplicada em materiais nanoporosos, nos quais são constituídos de vazios ou canais na escala nanométrica, podendo ser trabalhadas na escala micrométrica. Os microporos são os poros classificados com diâmetro menor que $0,002 \mu \mathrm{m}$ ( $2 \mathrm{~nm}$, ou $20 \AA$ ); os mesoporos com diâmetro entre 0,002 e $0,05 \mu \mathrm{m}$; os macroporos com diâmetros entre 0,05 e 7,5 $\mu \mathrm{m}$. E por fim, os megaporos com diâmetro maior que $7,5 \mu \mathrm{m}$.

Essa classificação se assemelha com várias classificações para poros de solos propostas por diferentes autores na literatura, dentre esses Everett (1972), Webb e Orr (1997) e Luxmoore (1980). A Tabela 5.3 apresenta as porcentagens de distribuição de poros nas amostras indeformadas.

Nota-se em todas as análises de PIM realizadas nesta pesquisa a ausência dos diâmetros menores que 0,002 $\mu \mathrm{m}$, no qual caracteriza os microporos. Este fato ocorreu em Pereira (2004) e Loch (2013). Os autores afirmam que esses microporos não foram atingidos pelo mercúrio devido à necessidade de maiores pressões de injeção para a introdução do mesmo, e, porém, essas pressões execedem a capacidade do equipamento utilizado. 
Tabela 5.3 - Porcentagem de distribuição dos poros nas amostras indeformadas da Formação Corumbataí.

\begin{tabular}{|cc|c|c|c|}
\hline \multicolumn{5}{|c|}{ Distribuição dos Poros por Diâmetro (\%) } \\
\hline \multirow{2}{*}{ Amostras } & & \multicolumn{3}{c|}{ IUPAC (1985) } \\
\cline { 3 - 5 } & & $\begin{array}{c}\text { Micro e Meso } \\
0,002<\varnothing<0,05 \mu \mathrm{m}\end{array}$ & \begin{tabular}{c} 
Macro \\
\multicolumn{2}{|c|}{ Meg $<\varnothing<7,5 \mu \mathrm{m}$}
\end{tabular} & $\varnothing>7,5 \mu \mathrm{m}$ \\
\hline \multirow{2}{*}{ Indeformada Seca ao Ar } & Antes & 37,51 & 61,76 & 0,73 \\
& Após & 33,56 & 61,96 & 4,48 \\
\hline Indeformada Estabilizada & Antes & 37,57 & 61,25 & 1,18 \\
em 40.000 kPa & Após & 37,65 & 52,74 & 9,61 \\
\hline Indeformada Estabilizada & Antes & 39,65 & 59,48 & 0,87 \\
em 25.000 kPa & Após & 30,33 & 61,53 & 8,14 \\
\hline Indeformada Estabilizada & Antes & 39,65 & 58,01 & 2,34 \\
em 10.000 kPa & Após & 31,18 & 62,05 & 6,77 \\
\hline Indeformada Estabilizada & Antes & 49,89 & 49,79 & 0,32 \\
em 5.000 kPa & Após & 31,31 & 57,26 & 11,43 \\
\hline
\end{tabular}

De modo geral, é possível notar na Tabela 5.3 que as amostras indeformadas apresentaram maior porcentagem de macroporos antes e após o ensaio. Essas amostras sofreram uma redução nos mesos e microporos após a expansão inundada, com exceção da amostra estabilizada na sucção de $40.000 \mathrm{kPa}$. Pode-se afirmar que essa redução foi distribuída entre os macros e megaporos desta classificação.

Analisando a micro e mesoporosidade, observa-se, um comportamento inesperado na porosimetria das amostras indeformadas antes do ensaio de expansão por inundação, em que as condições mais secas exibiram menos porcentagem de micro e mesoporo. Enquanto que, as amostras mais úmidas (estabilizadas nas sucções de 25.000, 10.000 e $5.000 \mathrm{kPa}$ ) apresentaram maior porcentagem de micro e mesoporo. Esperava-se que as amostras com sucção mais elevada, ou seja, as mais secas apresentassem porcentagem de micro e mesoporo maior do que as outras condições. No entanto, após a inundação, as porcentagens de micro e mesoporo de todas as amostras diminuíram, sendo essa diminuição em menor escala para as amostras mais secas. Nas amostras mais úmidas, os microporos aumentaram de tamanho após a inundação. A amostras estabilizada na sucção de $40.000 \mathrm{kPa}$ pode ter sofrido alguma alteração durante a execução do ensaio de PIM, visto que, após inundada não se vê variação na microestrutura do material. Ou, ainda, pode ser resultado da heterogeneidade da amostra indeformada.

Nota-se na Tabela 5.4 que há uma diferença entre a porosidade calculada pelos índices físicos e a porosidade determinada pelo ensaio de PIM. Essa diferença pode ser justificada pela 
aplicação de elevadas pressões de injeção de mercúrio na amostra, no qual deve ter promovido alterações na microestrutura do material. Vale ressaltar que as maiores diferenças entre as porosidades foram exibidas nas amostras estabilizadas nas sucções de 40.000, 25.000 e $10.000 \mathrm{kPa}$. Este fato pode ter ocorrido pela heterogeneidade do material indeformado.

Tabela 5.4 - Comparação entre porosidade calculada e a porosidade determinada pela PIM para as amostras indeformadas da Formação Corumbataí.

\begin{tabular}{|c|c|c|}
\hline \multirow{2}{*}{ Amostras } & \multicolumn{2}{|c|}{ Porosidade (\%) } \\
\cline { 2 - 3 } & $\boldsymbol{\eta}$ calc. & $\boldsymbol{\eta}$ PIM \\
\hline Seca ao ar & 37,68 & 38,09 \\
\hline $40.000 \mathrm{kPa}$ & 27,40 & 37,93 \\
\hline $25.000 \mathrm{kPa}$ & 26,81 & 37,19 \\
\hline $10.000 \mathrm{kPa}$ & 32,70 & 37,73 \\
\hline $5.000 \mathrm{kPa}$ & 36,91 & 36,41 \\
\hline
\end{tabular}

5.1.1.2 Microscopia Eletrônica de Varredura - Amostras Indeformadas

As imagens obtidas a partir da microscopia eletrônica de varredura (MEV) para as amostras indeformadas da Formação Corumbataí são mostradas a seguir na Figura 5.7 para a condição antes do ensaio de expansão, e na Figura 5.9 para a condição após o ensaio de expansão inundada. Todas as análises foram realizadas na direção perpendicular à estratificação do material. 

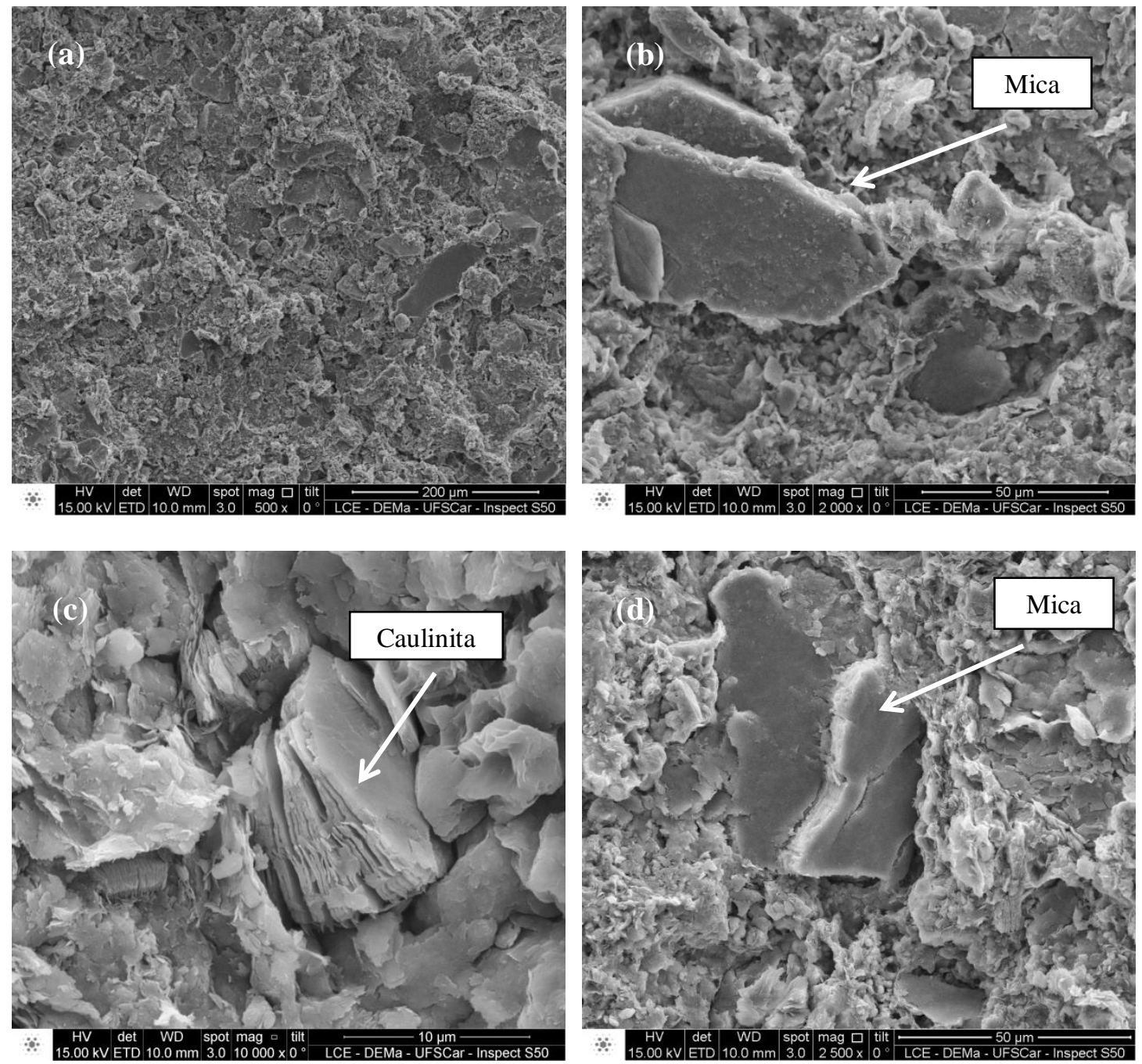

Figura 5.7 - Microscopia eletrônica de varredura da amostra indeformada na condição seca ao ar antes do ensaio de expansão inundada.

É possível notar na Figura 5.7(a) uma visão geral da textura da amostra antes da expansão. A Figura 5.7(b) e (d) mostram a presença de placas de mica (ilita) orientadas. Já a Figura 5.7(b) ilustra com detalhe a presença de argilominerais do grupo da caulinita. Observa-se também, a ausência de orientação preferencial e a ocorrência de espaços vazios entre as placas de caulinita.

Da Figura 5.7(a) foi realizada a análise semi quantitativa da composição química do material utilizando-se a microssonda eletrônica. A Figura 5.8 mostra os elementos químicos determinados pela leitura do diagrama espectral EDS, no qual constatou a presença de $\mathrm{Al}, \mathrm{Si}$, $\mathrm{O}, \mathrm{Mg}, \mathrm{K}$, dentre outros em pequenas porcentagens. 


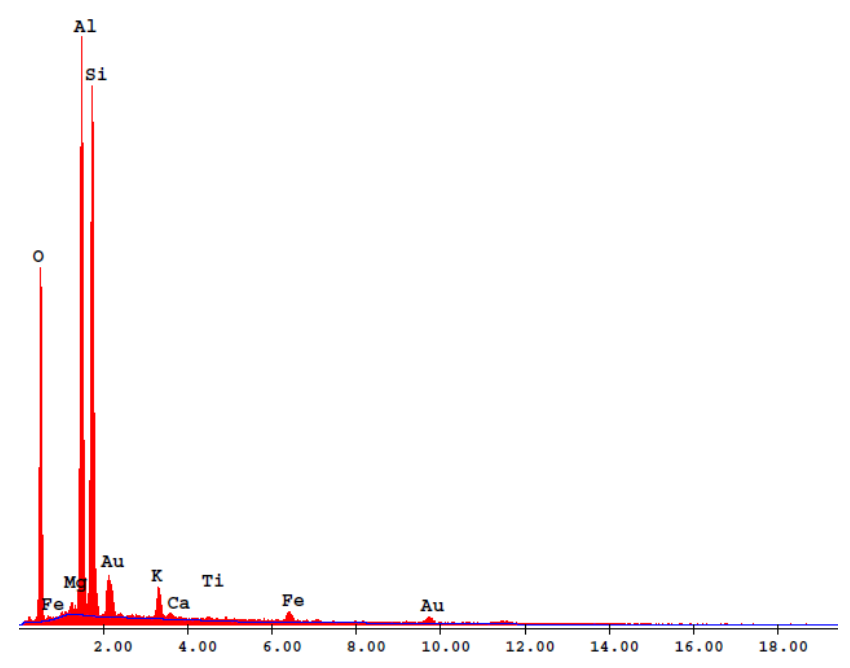

Figura 5.8 - Substâncias químicas constituintes na amostra indeformada antes do ensaio de expansão inundada.

Para a condição após o ensaio de expansão, as imagens do MEV são apresentadas na Figura 5.9. A Figura 5.9(a) apresenta uma visão geral da amostra com aumento de 1.000x, permitindo mostrar as trincas e fissuras ocorridas após o processo de expansão pela entrada de água, o que provocou a ocorrência de vazios no interior da amostra. A Figura 5.9(b) exibe a caulinita com as "folhas" mais espaçadas e a presença de vazios entre as mesmas. A Figura 5.9(c) e (d) ilustram o detalhamento da caulinita após a expansão. É visível a mudança na textura e arranjo dos grãos após o ensaio de expansão inundada. 

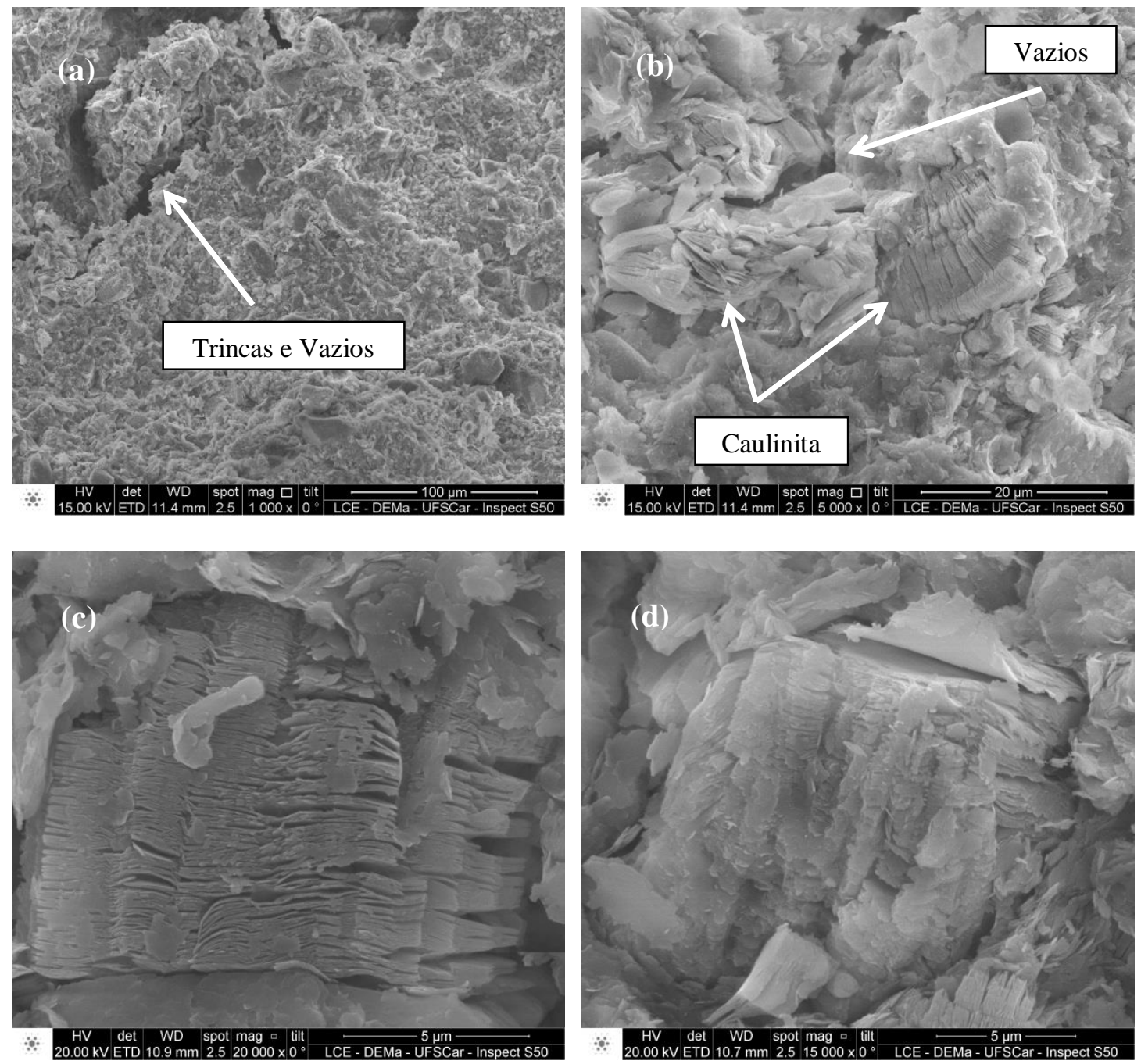

Figura 5.9 - Microscopia eletrônica de varredura da amostra indeformada na condição seca ao ar após do ensaio de expansão inundada.

\subsubsection{Distribuição de Poros - Amostras Compactadas}

Para as amostras compactadas, também, foram realizadas PIM antes e após o ensaio de expansão inundada. A Figura 5.10 apresenta os resultados da amostra compactada com o material seco ao ar, a Figura 5.11 os dados da amostra compactada na umidade ótima e seca ao ar após a compactação, a Figura 5.12 os dados da amostra compactada na umidade ótima e estabilizada na solução salina de $\mathrm{NaCl}$ de $40.000 \mathrm{kPa}$, a Figura 5.13 os dados da amostra compactada na umidade ótima e estabilizada na solução salina de $\mathrm{NaCl}$ de $25.000 \mathrm{kPa}$, a Figura 5.14 os dados da amostra compactada na umidade ótima e estabilizada na solução salina de $\mathrm{NaCl}$ de $10.000 \mathrm{kPa}$, e a Figura 5.15 os dados da amostra compactada na umidade ótima e estabilizada na solução salina de $\mathrm{NaCl}$ de $5.000 \mathrm{kPa}$. 


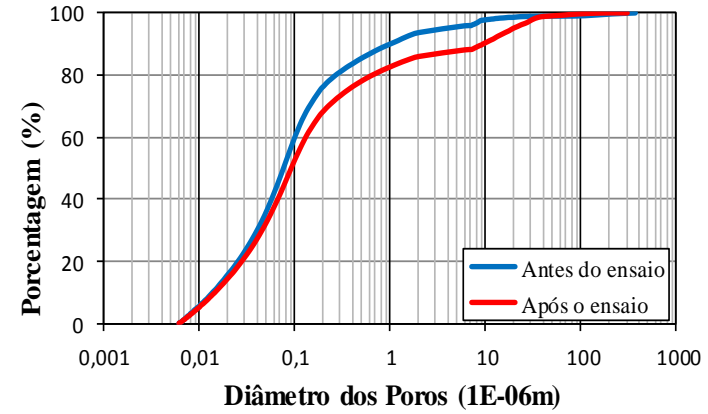

(a)

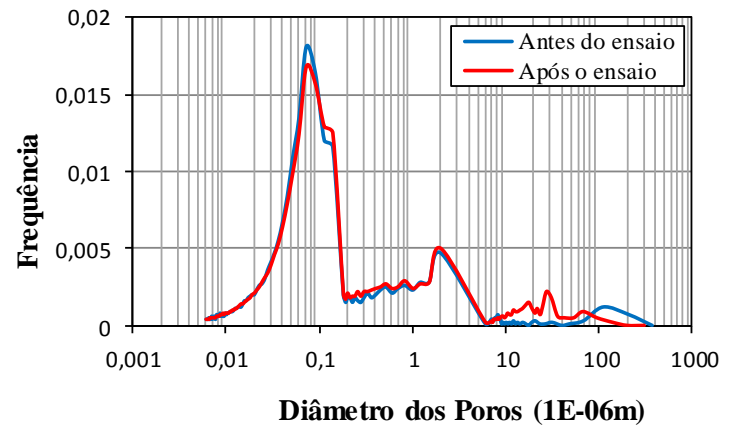

(b)

Figura 5.10 - Porosimetria por intrusão de mercúrio para amostra compactada seca e umidade estabilizada seca ao ar: (a) Porcentagem versus diâmetro dos poros; (b) Frequência dos intervalos de diâmetros.

A distribuição de poros nas amostras compactadas é definida visualmente de forma bimodal, onde é possível determinar o intervalo dos microporos, macroporos, e também de poros intermediários. Nas Figura 5.10 e Figura 5.11 observa-se que tanto as amostras compactadas com material seco quanto as compactadas na umidade ótima e secas ao ar não apresentaram evolução na distribuição de poros após o ensaio, apenas uma pequena redução na frequência dos microporos.

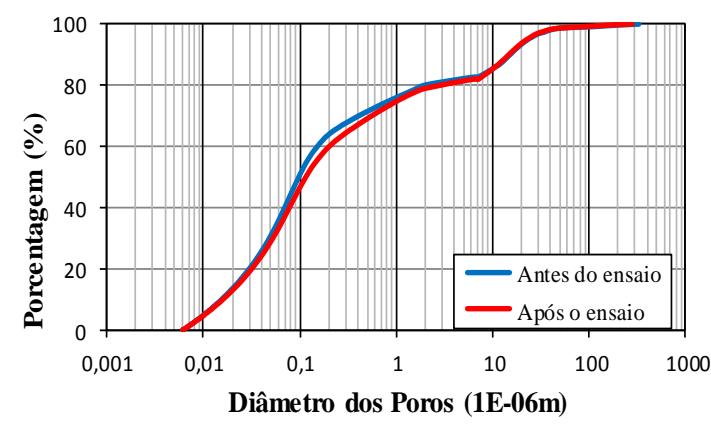

(a)

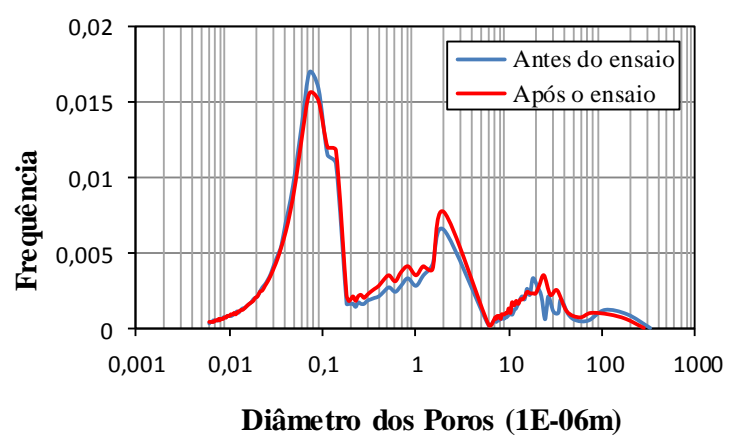

(b)

Figura 5.11 - Porosimetria por intrusão de mercúrio para amostra compactada na umidade ótima e estabilizada seca ao ar: (a) Porcentagem versus diâmetro dos poros; (b) Frequência dos intervalos de diâmetros.

Na Figura 5.12 é possível observar a variação que ocorreu nos macroporos da amostra estabilizada na sucção de $40.000 \mathrm{kPa}$. Houve uma redução no tamanho dos macroporos após a expansão, e o surgimento de dois intervalos intermediários entre os diâmetros de $1 \mu \mathrm{m}$ e $20 \mu \mathrm{m}$. Pode ter ocorrido algum problema durante a execução do ensaio, visto que, este valor alto de microporo foi anômalo em relação às outras amostras, desaparecendo após a expansão. 


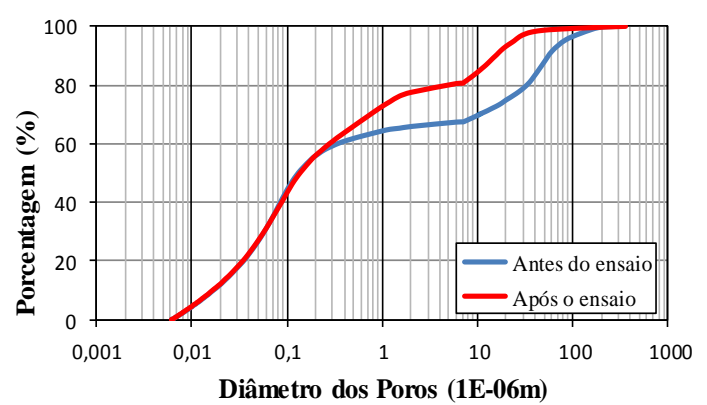

(a)

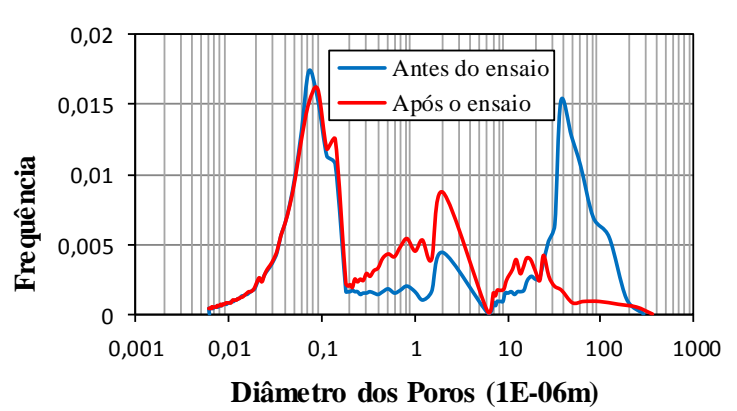

(b)

Figura 5.12 - Porosimetria por intrusão de mercúrio para amostra a amostra compactada na umidade ótima, e depois estabilizada na sucção de $40.000 \mathrm{kPa}$ : (a) Porcentagem versus diâmetro dos poros; (b) Frequência dos intervalos de diâmetros.

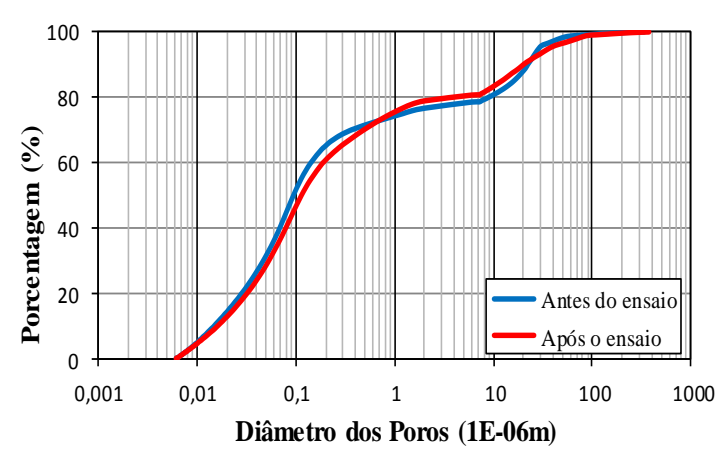

(a)

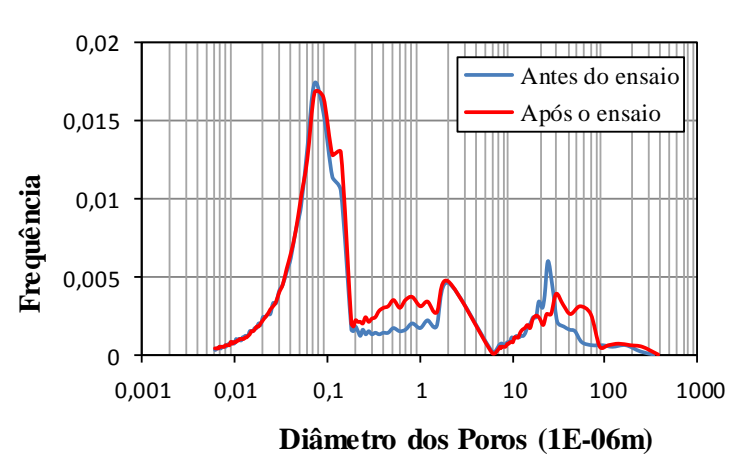

(b)

Figura 5.13 - Porosimetria por intrusão de mercúrio para amostra a amostra compactada na umidade ótima, e depois estabilizada na sucção de $25.000 \mathrm{kPa}$ : (a) Porcentagem versus diâmetro dos poros; (b) Frequência dos intervalos de diâmetros.

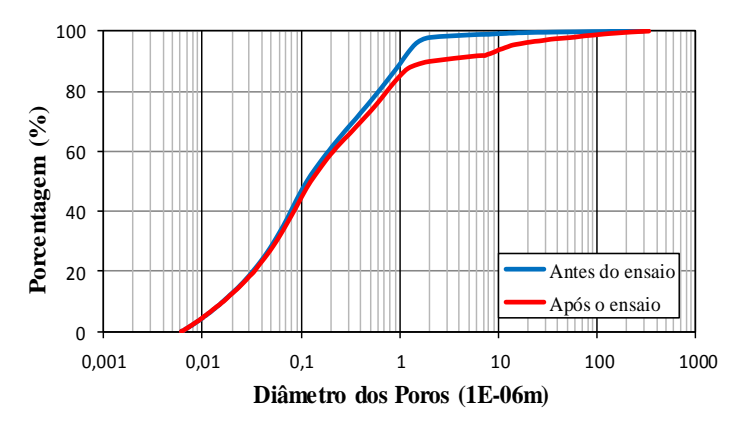

(a)

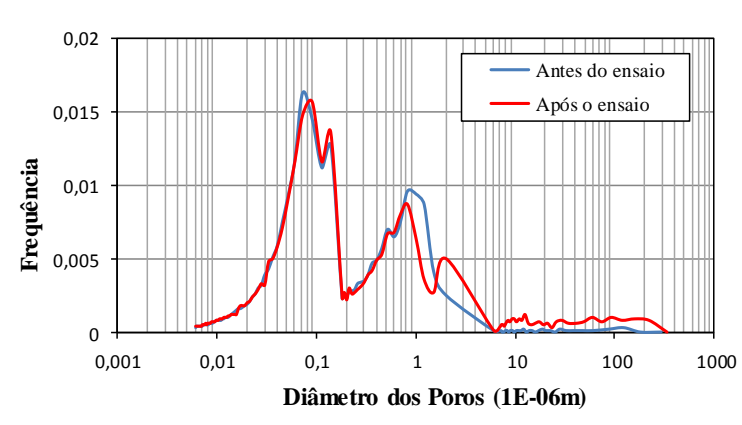

(b)

Figura 5.14 - Porosimetria por intrusão de mercúrio para amostra a amostra compactada na umidade ótima, e depois estabilizada na sucção de $10.000 \mathrm{kPa}$ : (a) Porcentagem versus diâmetro dos poros; (b) Frequência dos intervalos de diâmetros.

De maneira geral, as amostras estabilizadas nas sucções de 40.000, 25.000, 10.000 e 5.000 $\mathrm{kPa}$ apresentaram variação pequena de microporo. As modificações ocorreram, principalmente, ao nível dos macroporo após o ensaio de expansão. 


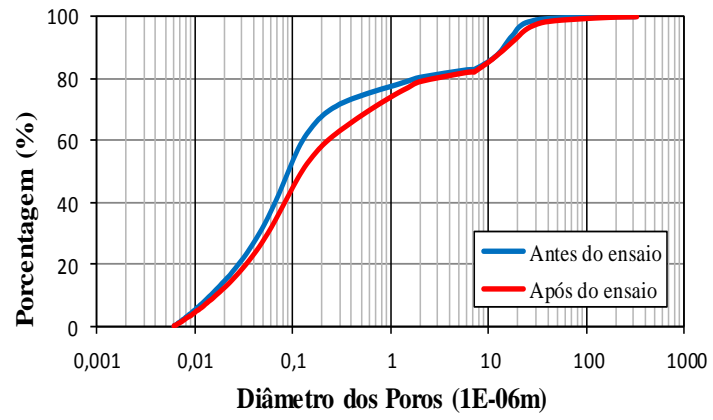

(a)

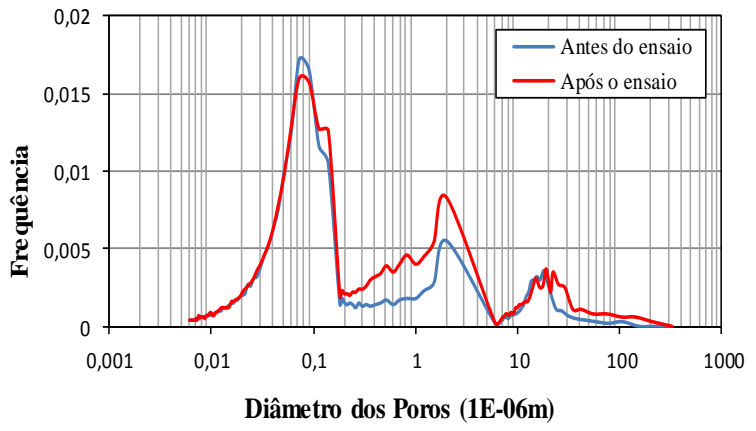

(b)

Figura 5.15 - Porosimetria por intrusão de mercúrio para amostra a amostra compactada na umidade ótima, e depois estabilizada na sucção de $5.000 \mathrm{kPa}$ : (a) Porcentagem versus diâmetro dos poros; (b) Frequência dos intervalos de diâmetros.

O comportamento dos poros das amostras que apresentaram máxima pressão de expansão, tanto na condição indeformada, como na condição compactada, não revelaram evolução e mudança após o ensaio inundado. Nesses casos, pode-se afirmar que a expansão tenha sido governada pela sucção inicial das amostras. Essa sucção inicial promoveu à superfície específica da argila forças de atração pelas moléculas de água. No entanto, essa absorção de água entre as camadas do argilomineral não promoveu variação significativa na distribuição dos poros.

A porcentagem de distribuição de poros das amostras compactadas é apresentada na Tabela 5.5. Da mesma forma como das amostras indeformadas, as compactadas também são constituídas, em sua maioria, de macroporos antes e após o ensaio.

A porcentagem de distribuição de poros permitiu constatar que ocorreu uma variação em todos os tamanhos de poros dessas amostras. A variação foi mais acentuada no intervalo de megaporo desta classificação, com exceção das amostras estabilizadas na sucção de 40.000 e $25.000 \mathrm{kPa}$, nas quais houve uma diminuição de megaporo. Em contrapartida, as amostras apresentaram aumento nos respectivos macroporos. O fato do aumento de megaporo após a inundação pode ser justificado pela presença de vazios de maior dimensão em comparação com os vazios das amostras indeformadas. 
Tabela 5.5 - Porcentagem de distribuição dos poros das amostras compactadas.

\begin{tabular}{|c|c|c|c|c|}
\hline \multicolumn{5}{|c|}{ Distribuição dos Poros por Diâmetro (\%) } \\
\hline \multirow[b]{2}{*}{ Amostras } & & \multicolumn{3}{|c|}{ IUPAC (1985) } \\
\hline & & $\begin{array}{c}\text { Micro e Meso } \\
0,002<\varnothing<0,05 \mu \mathrm{m}\end{array}$ & $\begin{array}{c}\text { Macro } \\
0,05<\varnothing<7,5 \mu \mathrm{m}\end{array}$ & $\begin{array}{c}\text { Mega } \\
\varnothing>7,5 \mu \mathrm{m} \\
\end{array}$ \\
\hline \multirow{2}{*}{$\begin{array}{c}\text { Compactada Seca/ Seca } \\
\text { ao Ar }\end{array}$} & Antes & 36,92 & 59,49 & 3,59 \\
\hline & Após & 33,21 & 55,40 & 11,39 \\
\hline \multirow{2}{*}{$\begin{array}{l}\text { Compactada na } \mathrm{W}_{\text {ot }} l \\
\text { Secao ao Ar }\end{array}$} & Antes & 31,75 & 51,30 & 16,95 \\
\hline & Após & 29,62 & 52,86 & 17,52 \\
\hline \multirow{2}{*}{$\begin{array}{c}\text { Compactada Estabilizada } \\
\text { em } 40.000 \mathrm{kPa}\end{array}$} & Antes & 27,59 & 40,30 & 32,11 \\
\hline & Após & 27,81 & 53,74 & 18,45 \\
\hline \multirow{2}{*}{$\begin{array}{c}\text { Compactada Estabilizada } \\
\text { em } 25.000 \mathrm{kPa}\end{array}$} & Antes & 32,49 & 46,33 & 21,18 \\
\hline & Após & 29,41 & 51,63 & 18,96 \\
\hline \multirow{2}{*}{$\begin{array}{c}\text { Compactada Estabilizada } \\
\text { em } 10.000 \mathrm{kPa}\end{array}$} & Antes & 29,31 & 69,62 & 1,07 \\
\hline & Após & 28,28 & 63,76 & 7,96 \\
\hline \multirow{2}{*}{$\begin{array}{c}\text { Compactada Estabilizada } \\
\text { em } 5.000 \mathrm{kPa}\end{array}$} & Antes & 33,10 & 50,24 & 16,66 \\
\hline & Após & 28,39 & 54,14 & 17,47 \\
\hline
\end{tabular}

Vale comentar, ainda, o destaque da porcentagem de macroporos da amostra estabilizada na sucção de $10.000 \mathrm{kPa}$ antes do ensaio no valor de 69,62\%. Esse aumento foi referente à compensação de megaporos no valor de apenas $1,07 \%$. Isso pode ter ocorrido devido ao processo de compactação da amostra, o qual promoveu um arranjo diferente neste corpo de prova.

As diferenças entre as porosidades calculadas e as porosidades determinadas pelo PIM são apresentadas na Tabela 5.6. Para os casos das amostras: compactada na umidade ótima, e posteriormente, seca ao ar; compactada na condição seca (pó), seca ao ar; e da compactada na umidade ótima, e posteriormente, estabilizada na sucção de $25.000 \mathrm{kPa}$; a porosimetria por intrusão de mercúrio não conseguiu alcançar todos os poros, exibindo porosidade menor do que a porosidade calculada pelos índices físicos. Isso ocorreu devido à limitação do equipamento, no qual não permite aplicar maiores pressões de injeção no mercúrio. Nas demais condições (amostras compactadas na umidade ótima, e posteriormente, estabilizadas nas $40.000,10.000$ e $5.000 \mathrm{kPa}$ ), as diferenças são resultados de alteração da microestrutura do material pela aplicação da pressão de injeção de mercúrio. 
Tabela 5.6 - Comparação entre porosidade calculada e a porosidade determinada pela PIM para as amostras compactadas da Formação Corumbataí.

\begin{tabular}{|c|c|c|}
\hline \multirow{2}{*}{ Amostra } & \multicolumn{2}{|c|}{ Porosidade (\%) } \\
\cline { 2 - 3 } & $\boldsymbol{\eta}_{\text {calc. }}$ & $\boldsymbol{\eta}_{\text {PIM }}$ \\
\hline $\mathrm{W}_{\text {ot }}$ Seca ao ar & 43,61 & 42,38 \\
\hline Seca/ Seca ao ar & 42,85 & 37,99 \\
\hline $40.000 \mathrm{kPa}$ & 41,96 & 45,31 \\
\hline $25.000 \mathrm{kPa}$ & 44,30 & 41,19 \\
\hline $10.000 \mathrm{kPa}$ & 42,10 & 43,33 \\
\hline $5.000 \mathrm{kPa}$ & 39,87 & 40,23 \\
\hline
\end{tabular}

\subsubsection{Microscopia Eletrônica de Varredura - Amostras Compactadas}

Foram realizadas análises de MEV nas amostras compactadas da Formação Corumbataí para as mesmas condições das indeformadas, antes e após os ensaios de expansão inundada, a fim de comparar o arranjo do material. A Figura 5.16 mostra as imagens da amostra compactada na condição seca e seca ao ar antes do ensaio na direção perpendicular à estratificação do material.

A Figura 5.16(a) ilustra uma visão geral da textura da amostra com aumento de 1.000x. A Figura 5.16(b) exibe uma aproximação da caulinita presente no material. Com um aumento de 2.000x, a Figura 5.16(c) mostra que a textura do material foi modificada com o processo de compactação, já apresentando vazios de dimensões maiores antes do ensaio de expansão. A Figura 5.16(d) mostra a textura novamente com maior detalhe em um aumento 8.000x.

A composição química obtida com a sonda EDS, mostrada na Figura 5.17, é a mesma encontrada para a amostra indeformada, confirmando a presença das substâncias químicas Al, $\mathrm{Si}, \mathrm{O}, \mathrm{K}, \mathrm{Mg}$, dentre outros em pequenas porcentagens. 

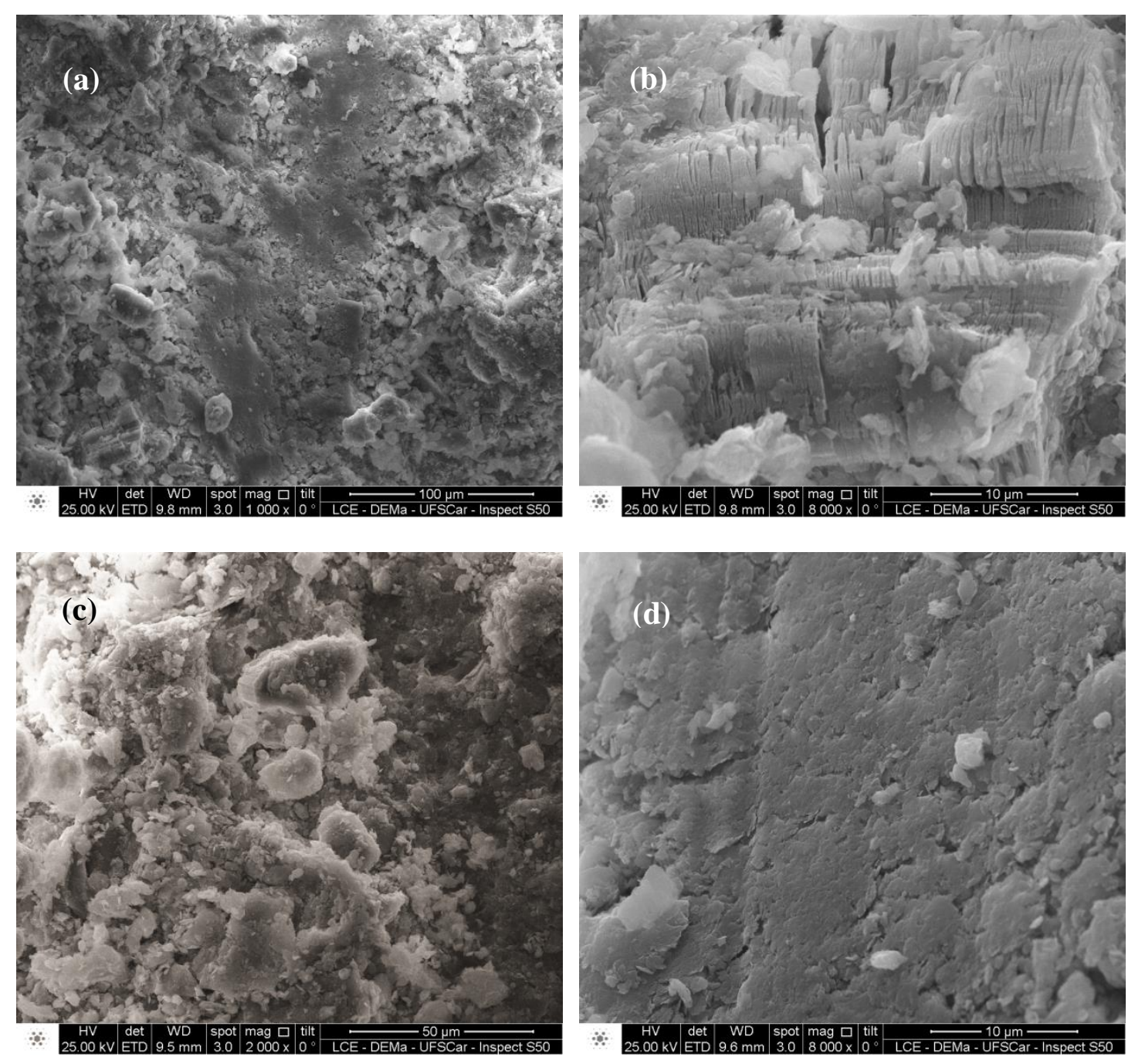

Figura 5.16 - Microscopia eletrônica de varredura da amostra compactada seca, e seca ao ar após compactação antes do ensaio de expansão inundada.

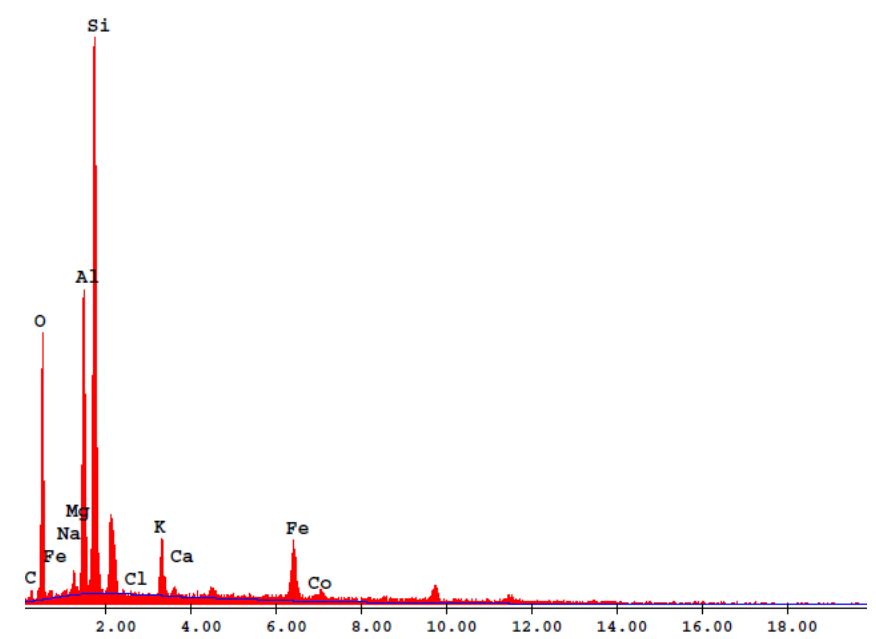

Figura 5.17 - Substâncias químicas constituintes na amostra compactada seca (pó), seca ao ar antes do ensaio de expansão inundada. 
Após o ensaio de expansão, foram obtidas imagens no MEV mostradas na Figura 5.18. É possível observar a diferença significativa na estrutura da amostra compactada seca após a inundação pelo aspecto textural e modificação do arranjo. A Figura 5.18(a) mostra a textura da amostra em um aumento de 5.000x. Com um aumento de 20.000x, a Figura 5.18(b) apresenta uma quantidade expressiva de vazios, com certa dispersão do material. As micas confinadas que sofreram expansão e fratura podem ser visualizadas na Figura 5.18(c), bem como, os vazios de maior dimensão. Na Figura 5.18(d), com um aumento de 40.000x, observa-se em detalhe a presença de vazios no material disperso visto na Figura 5.18(b), e também a desagregação das partículas.
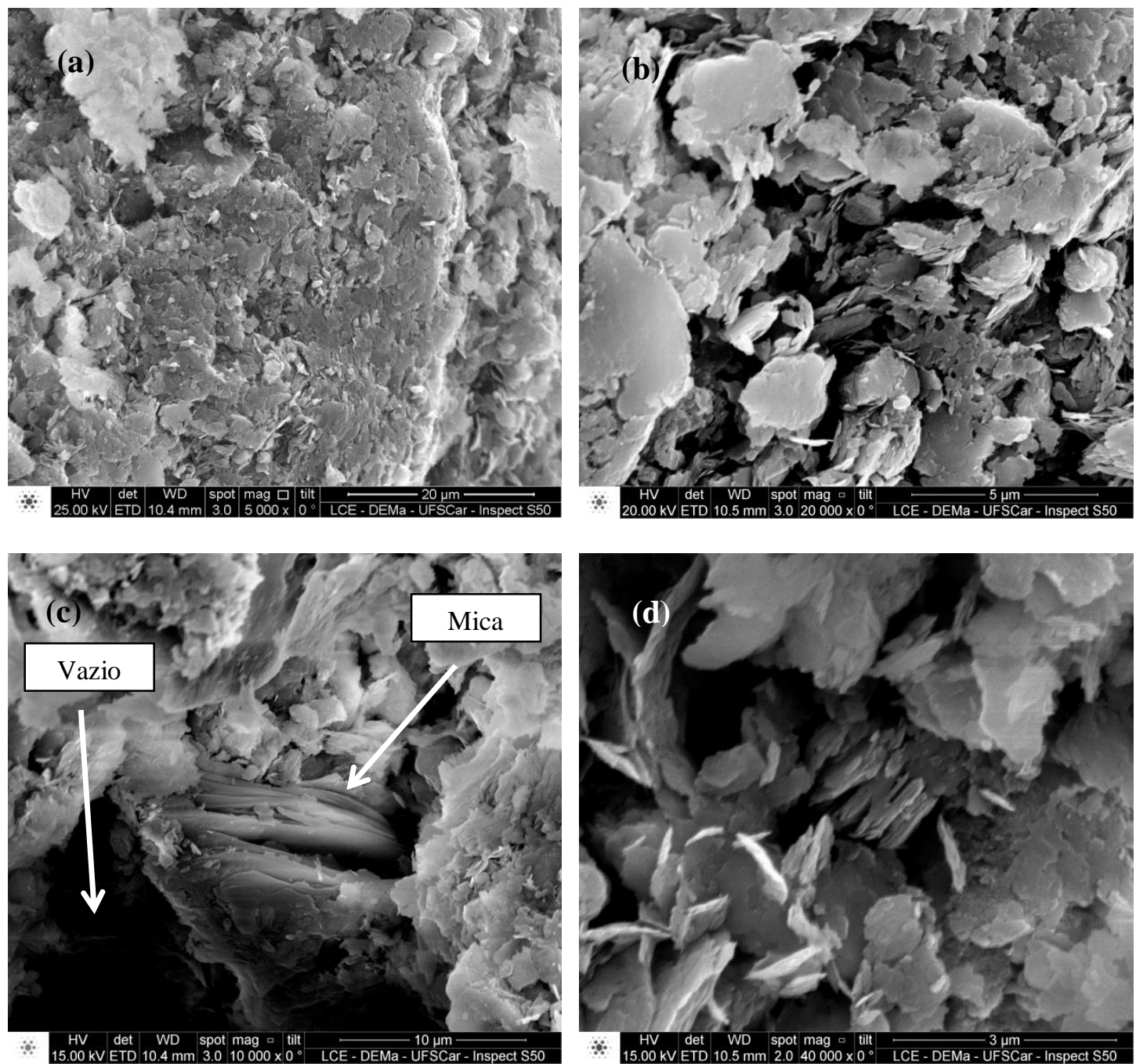

Figura 5.18 - Microscopia eletrônica de varredura da amostra compactada seca, e seca ao ar após o ensaio de expansão inundada.

A microscopia eletrônica de varredura da amostra compactada na umidade ótima e depois seca ao ar está mostrada na Figura 5.19. A Figura 5.19(a) mostra a textura da amostra em um aumento de 1.000x. Percebe-se que a compactação na umidade ótima conduziu a uma 
orientação mais bem definida das partículas planares maiores. A Figura 5.19(b) ilustra um arranjo de um grão de quartzo em meio à um vazio de grande dimensão. A Figura 5.19(c) mostra a caulinita em meio ao material disperso. E a Figura 5.19(d) mostra essa dispersão com vazios expressivos em um amento de 15.000x. Isto demonstra que em nível micro estrutural a compactação não foi efetiva o suficiente para promover a orientação dos argilominerais.
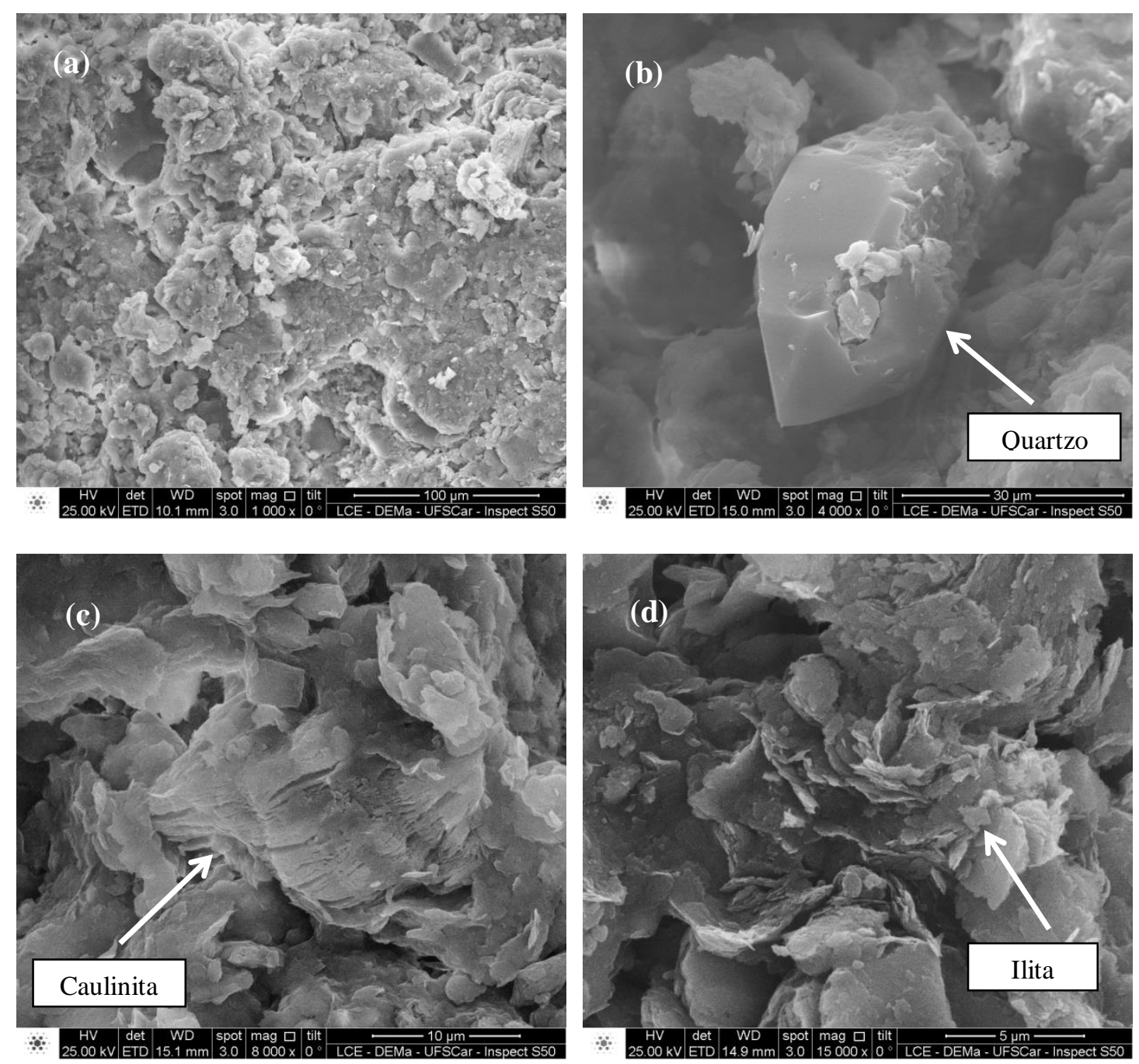

Figura 5.19 - Microscopia eletrônica de varredura da amostra compactada na umidade ótima e seca ao ar antes do ensaio de expansão inundada.

A Figura 5.20 mostra as imagens da amostra compactada na umidade ótima e seca ao ar após o ensaio de expansão. Não se observa diferenças significativas quando comparadas com as imagens desse material antes do ensaio, no entanto, nota-se um desarranjo estrutural, evidenciado pelo aumento de vazios, aparecimento de fraturas e menor orientação das partículas planares. A Figura 5.20(a) expõe uma visão geral da textura; a Figura 5.20(b) uma aproximação com aumento de 5.000x para mostrar a dispersão dos argilominerais; a Figura 
5.20(c) mostra um aumento de 10.000x facilitando a visualização do desarranjo estrutural da amostra; e a Figura 5.20(d) o detalhamento dos vazios de maior dimensão.
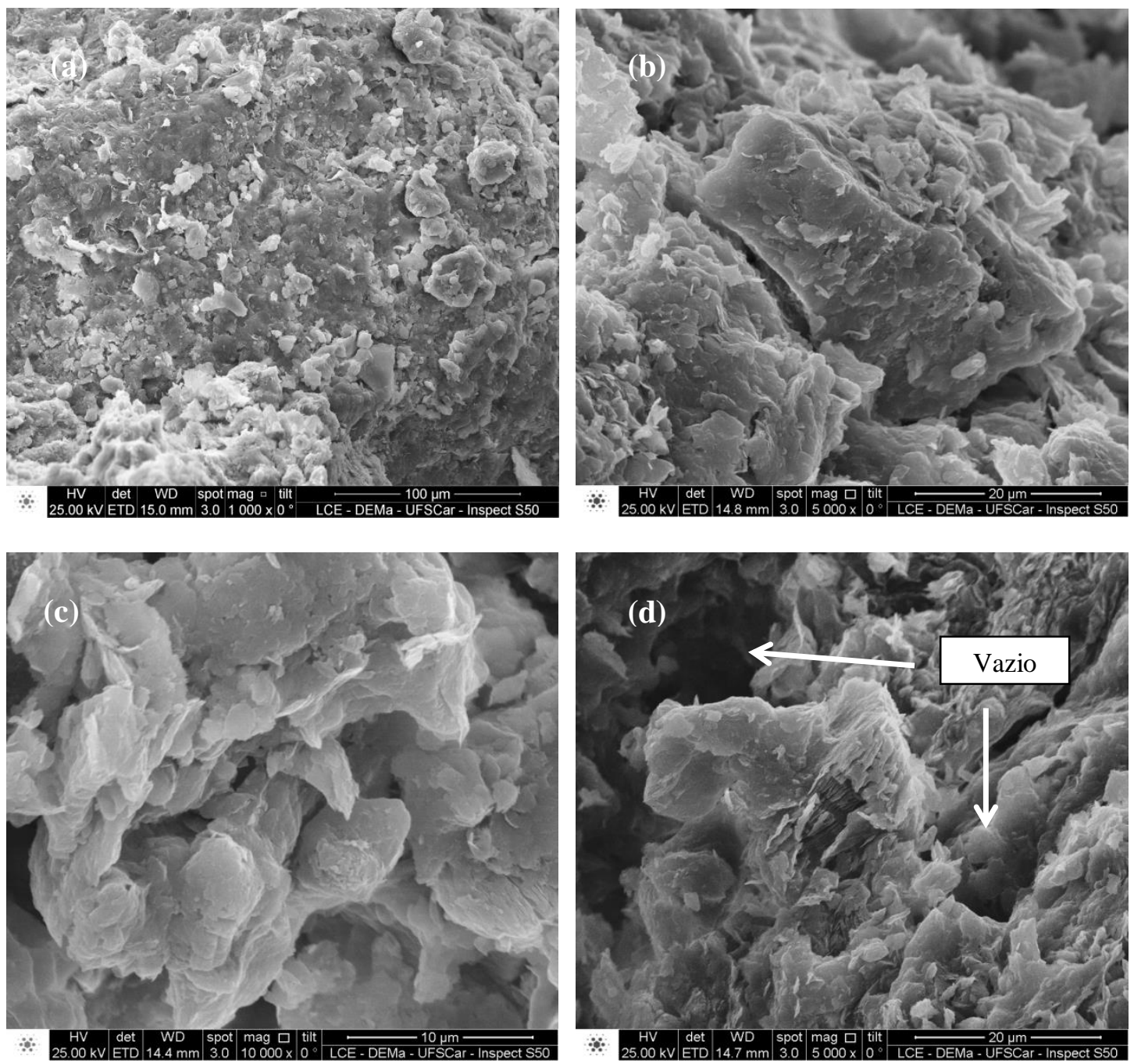

Figura 5.20 - Microscopia eletrônica de varredura da amostra compactada na umidade ótima e seca ao ar após o ensaio de expansão inundada.

5.1.2 Comportamento das Misturas de Material Argiloso da Formação Corumbataí com bentonita

Os ensaios inundados foram realizados, também, em misturas de solo argiloso da Formação Corumbataí com adição de bentonita nas proporções de 5\%, 10\%, 30\%, 50\% e 70\%, além, do ensaio com bentonita pura. As amostras foram compactadas diretamente no cilindro da célula edométrica imediatamente antes de iniciar o ensaio. As sucções iniciais foram calculadas em função das umidades relativas do ar do ambiente da sala de ensaio, as quais variaram entre 60.000 a $130.000 \mathrm{kPa}$. O objetivo foi buscar avaliar o efeito da presença de argilominerais do grupo das esmectitas no comportamento expansivo, principalmente no que tange aos ensaios 
de expansão com transferência de vapor, e as diferenças em relação ao ensaio com inundação da amostra.

As misturas com adição de 5\% e 10\% de bentonita apresentaram pressões de expansão fora do intervalo crescente de pressões das outras misturas, de $87 \mathrm{kPa}$ e $283 \mathrm{kPa}$ respectivamente, ou seja, os valores de expansão dessas duas misturas foram menores do que a expansão inundada com a amostra composta somente com material argiloso, no valor de $442 \mathrm{kPa}$. Este fato pode ter ocorrido pela porcentagem de bentonita nao ter sido suficiente para promover o aumento da pressão de expansão. Isto pode ter ocorrido devido essas duas amostras apresentarem sucção inicial mais baixa, com aproximadamente, a metade da sucção das outras misturas. Neste caso, a sucção pode ter governado este comportamento, bem como, os índices físicos da condição inicial das amostras.

As demais misturas apresentaram pressões crescente com valor máximo de cerca de $620 \mathrm{kPa}$ para a mistura de $70 \%$ de bentonita no material argiloso, com sucção inicial de $130.000 \mathrm{kPa}$. Este valor foi condizente com o obtido para amostra composta de bentonita pura, que apresentou aproximadamente $700 \mathrm{kPa}$ de expansão, com sucção inicial $86.000 \mathrm{kPa}$. Quanto aos índices físicos iniciais das amostras, pode-se afirmar que as umidades foram crescentes de acordo com o aumento da porcentagem de bentonita, bem como, os respectivos graus de saturação.

As pressões iniciais de expansão mostraram nas duas primeiras horas de ensaio valores maiores para a mistura de $30 \%$ de bentonita ao material argiloso em comparação à mistura de $50 \%$ ao solo. Após este momento, a expansão foi mobilizada e as misturas com maiores proporções de bentonita revelaram maiores pressões. Isso ocorre, também, na primeira hora de ensaio para a mistura de $50 \%$ de bentonita, com pressão de expansão maior do que a pressão da mistura de $70 \%$ de bentonita, e consequentemente, maior que da amostra de bentonita pura. Este fato pode ter ocorrido pela rápida entrada de água permitida pela elevada capacidade de absorção do material. Essa absorção de água está relacionada com o tipo de argilomineral, e também com as condições iniciais da amostra. De maneira geral, a estabilização da expansão ocorreu após oito horas de ensaio em todas as condições ensaiadas.

\subsubsection{Distribuição de Poros - Mistura de Material Argiloso com Bentonita}

Para esta condição, a porosimetria foi realizada apenas nas amostras antes do ensaio de expansão, o que não permite fazer uma análise da evolução após a expansão. A Figura 5.21 
apresenta a porosimetria da bentonita; a Figura 5.22 a porosimetria da amostra argilosa com mistura de 70\% de bentonita; a Figura 5.23 da amostra argilosa com mistura de 50\% de bentonita; a Figura 5.24 da amostra argilosa com mistura de $30 \%$ de bentonita; a Figura 5.25 da amostra argilosa com mistura de $10 \%$ de bentonita; e a Figura 5.26 da amostra argilosa com mistura de $5 \%$ de bentonita.

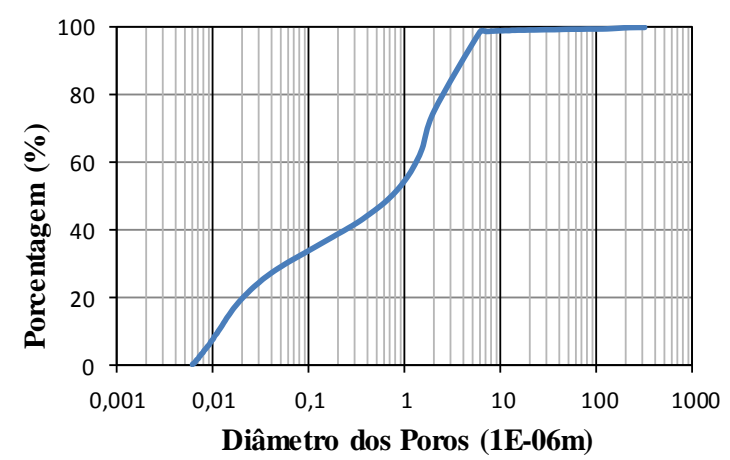

(a)

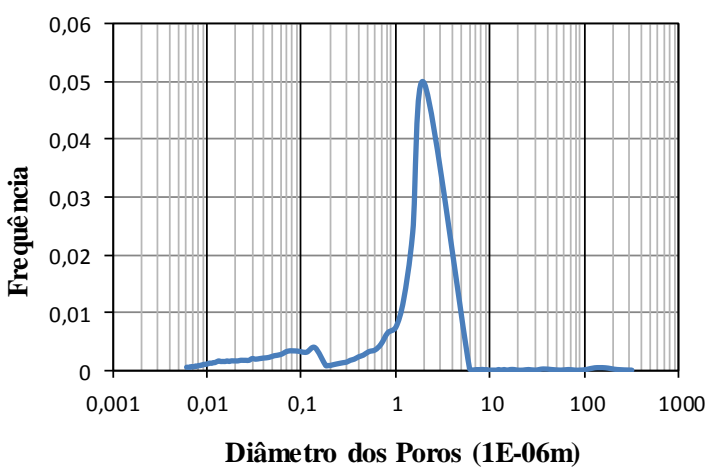

(b)

Figura 5.21 - Porosimetria por intrusão de mercúrio para amostra de bentonita compactada seca ao ar: (a) Porcentagem versus diâmetro dos poros; (b) Frequência dos intervalos de diâmetros.

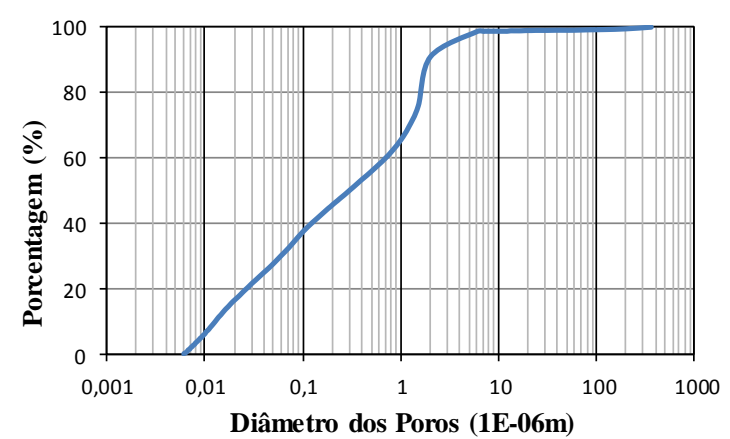

(a)

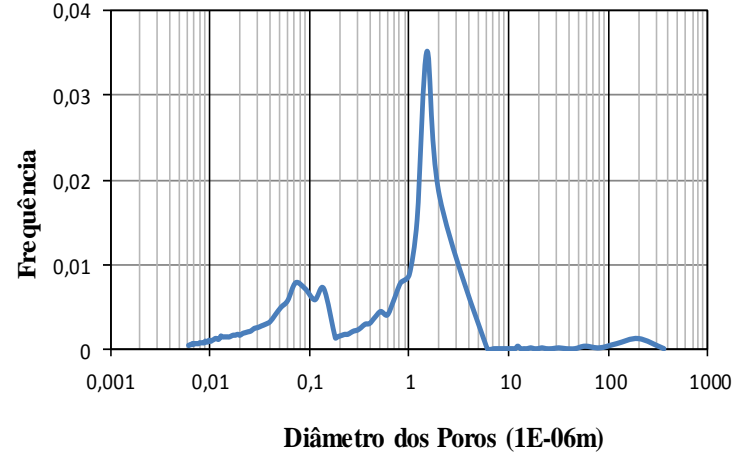

(b)

Figura 5.22 - Porosimetria por intrusão de mercúrio para amostra argilosa com $70 \%$ bentonita compactada seca ao ar: (a) Porcentagem versus diâmetro dos poros; (b) Frequência dos intervalos de diâmetros.

Para as misturas com $70 \%$ e $50 \%$ de bentonita, o pico de macroporo mostrou-se mais acentuado e definido. $\mathrm{O}$ intervalo de microporo apresentou frequência pouco definida nessas duas situações (Figura 5.22 e Figura 5.23). Isto revela a preponderância dos efeitos da adição de bentonita, que tem sua maior frequência de poros na faixa dos macroporos. Como o material compactado da Formação Corumbataí apresentou uma frequência de poros com diâmetros inferiores (Figura 5.10), as curvas de distribuição de poros evidenciam a distribuição bimodal para teores menores de bentonita (Figura 5.24 e Figura 5.25). 


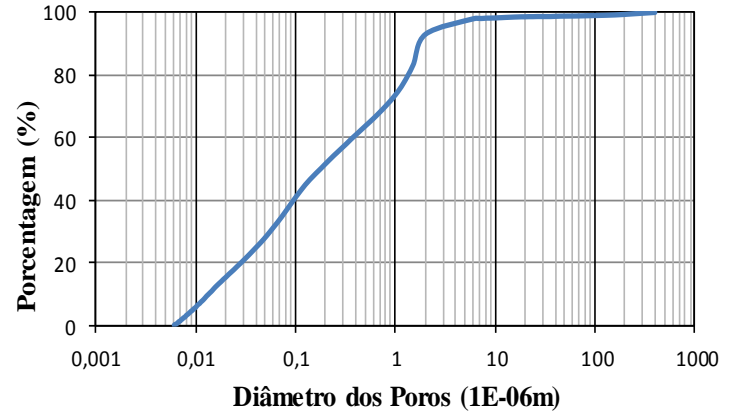

(a)

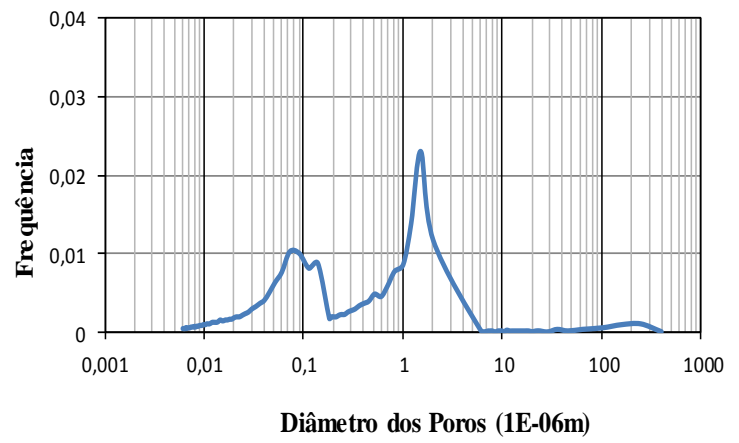

(b)

Figura 5.23 - Porosimetria por intrusão de mercúrio para amostra argilosa com 50\% bentonita compactada seca ao ar: (a) Porcentagem versus diâmetro dos poros; (b) Frequência dos intervalos de diâmetros.

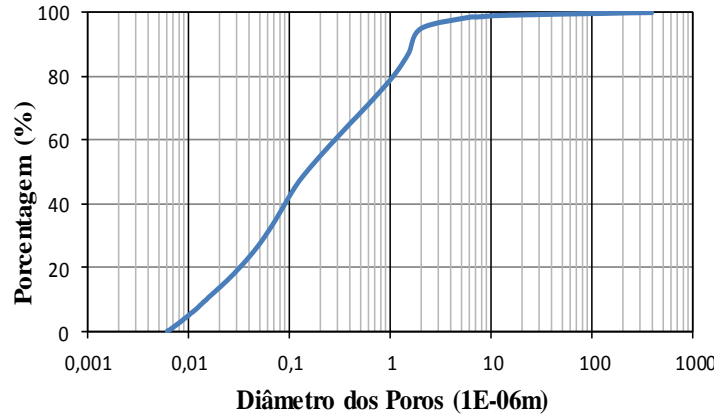

(a)

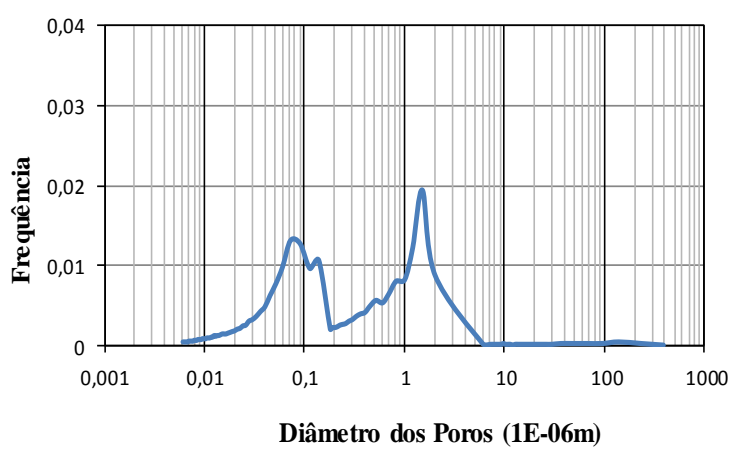

(b)

Figura 5.24 - Porosimetria por intrusão de mercúrio para amostra argilosa com 30\% bentonita compactada seca ao ar: (a) Porcentagem versus diâmetro dos poros; (b) Frequência dos intervalos de diâmetros.

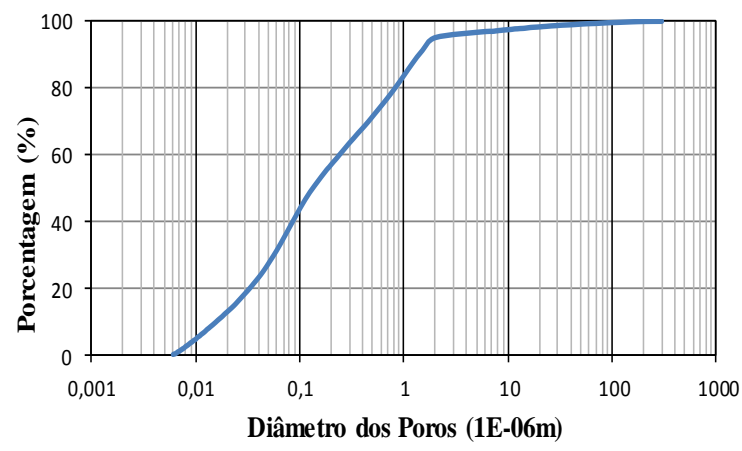

(a)

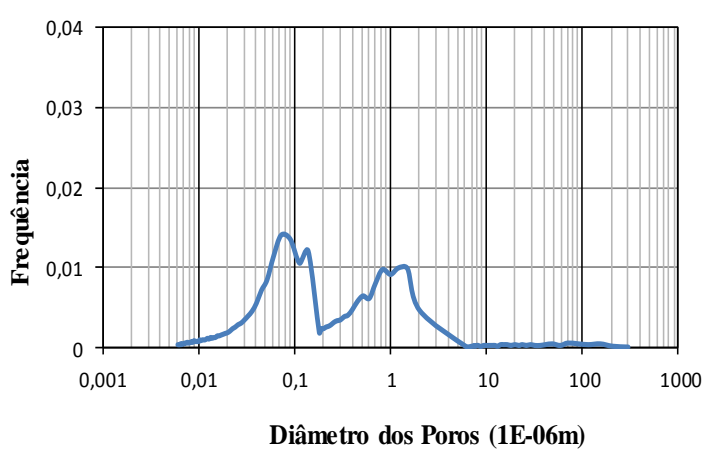

(b)

Figura 5.25 - Porosimetria por intrusão de mercúrio para amostra argilosa com $10 \%$ bentonita compactada seca ao ar: (a) Porcentagem versus diâmetro dos poros; (b) Frequência dos intervalos de diâmetros. 


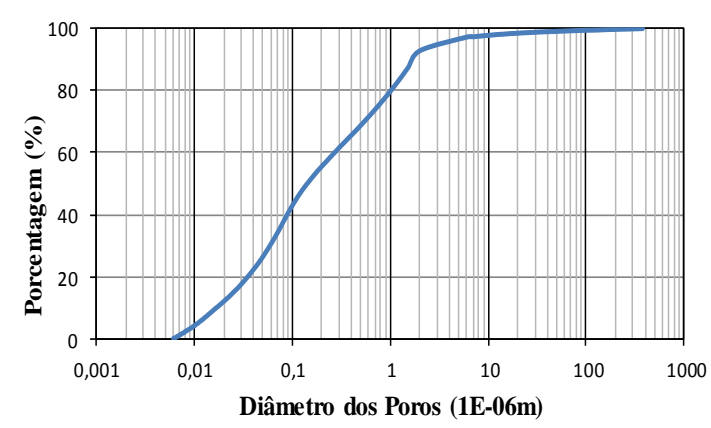

(a)

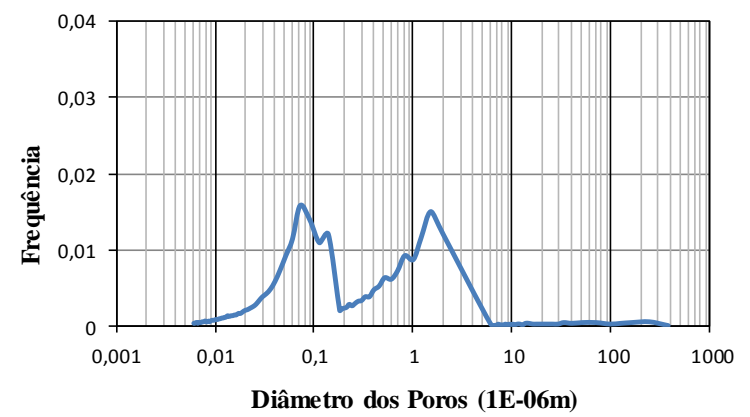

(b)

Figura 5.26 - Porosimetria por intrusão de mercúrio para amostra argilosa com 5\% bentonita compactada seca ao ar: (a) Porcentagem versus diâmetro dos poros; (b) Frequência dos intervalos de diâmetros.

Para esses ensaios, a distribuição de poros apresentou frequência similar para os intervalos de macroporo e microporo, revelando distribuições bimodais, com exceção da bentonita que apresentou uma distribuição unimodal.

Pode-se inferir que os macroporos das amostras de $50 \%$ e $70 \%$ de bentonita, ou poros de tamanho único configurados na porosimetria antes do ensaio de expansão podem ter parcela influência em conjunto com a sucção inicial para o comportamento expansivo. As misturas de $10 \%$ e $5 \%$ de bentonita não apresentam diferenças visuais significativas nas curvas de distribuição de poros.

A Tabela 5.7 mostra a porcentagem de distribuição de poros das amostras argilosas misturadas com bentonita somente para a condição antes da inundação. Para essas amostras, a maior porcentagem de tamanho de poro são os macroporos que constituem cerca de $70 \%$, seguido de $28 \%$ de meso e microporo, e apenas 1 a $2 \%$ de megaporo. Pode-se afirmar, então, que a expansão nessas amostras pode ser facilitada pela infiltração de água nos macroporos. Observa-se, ainda, na Tabela 5.7 que a adição de bentonita, em todos os casos, leva a um aumento da porcentagem de macroporo e diminuição dos micro e mesoporos em relação ao solo argiloso compactado sem adição da bentonita. 
Tabela 5.7 - Porcentagem de distribuição dos poros das amostras argilosas compactadas da Formação Corumbataí misturadas com bentonita.

\begin{tabular}{|c|c|c|c|}
\hline \multirow{2}{*}{ Amostras } & \multicolumn{3}{|c|}{ IUPAC (1985) } \\
\cline { 2 - 4 } & $\begin{array}{c}\text { Micro e Meso } \\
0,002<\varnothing<0,05 \mu \mathrm{m}\end{array}$ & $\begin{array}{c}\text { Macro } \\
0,05<\varnothing<7,5 \mu \mathrm{m}\end{array}$ & $\begin{array}{c}\text { Mega } \\
\varnothing>7,5 \mu \mathrm{m}\end{array}$ \\
\hline Bentonita & 29,13 & 69,68 & 1,19 \\
\hline Argiloso + 70\% Bentonita & 28,04 & 70,71 & 1,25 \\
\hline Argiloso + 50\% Bentonita & 28,68 & 69,40 & 1,92 \\
\hline Argiloso + 30\% Bentonita & 27,95 & 70,73 & 1,32 \\
\hline Argiloso + 10\% Bentonita & 28,03 & 69,02 & 2,95 \\
\hline Argiloso + 5\% Bentonita & 27,15 & 70,31 & 2,54 \\
\hline Argiloso & 36,92 & 59,49 & 3,59 \\
\hline
\end{tabular}

A Tabela 5.8 mostra as porosidades calculadas e as porosidades determinadas pelo PIM para as misturas de material argiloso com bentonita. Com exceção das misturas de $10 \%$ e $5 \%$, as demais amostras apresentaram porosidade menor determinada pela PIM, justificada pela impossibilidade do equipamento do alcançar poros menores. Já as misturas de $10 \%$ e 5\% exibiram porosidade maior pela PIM, o que significa que esses materiais estavam mais frágeis e susceptíveis à quebra e alteração da microestrutura durante a intrusão do mercúrio.

Tabela 5.8 - Comparação entre porosidade calculada e a porosidade determinada pela PIM para as amostras argilosas compactadas da Formação Corumbataí misturadas com bentonita.

\begin{tabular}{|c|l|c|}
\hline \multirow{2}{*}{ Amostra } & \multicolumn{2}{|c|}{ Porosidade (\%) } \\
\cline { 2 - 3 } & $\boldsymbol{\eta}$ calc. & $\boldsymbol{\eta}_{\text {PIM }}$ \\
\hline Bentonita & 49,30 & 36,14 \\
\hline Argiloso + 70\% & 43,96 & 40,96 \\
\hline Argiloso + 50\% & 44,13 & 40,95 \\
\hline Argiloso + 30\% & 43,34 & 42,55 \\
\hline Argiloso + 10\% & 42,04 & 42,44 \\
\hline Argiloso + 5\% & 42,22 & 44,41 \\
\hline Argiloso & 38,50 & 38,00 \\
\hline
\end{tabular}

\subsubsection{Microscopia Eletrônica de Varredura - Mistura de Material Argiloso com}

Bentonita

Para as misturas de material argiloso com bentonita e para a bentonita pura foi realizada a microscopia eletrônica de varredura, também, apenas para a condição antes do ensaio de expansão inundada, como se procedeu com a porosimetria.

A Figura 5.27 apresenta as imagens obtidas pelo MEV para a bentonita pura. A Figura 5.27(a) mostra uma visão geral da textura da amostra, que é diferenciada da amostra argilosa da 
Formação Corumbataí. Nota-se na Figura 5.27(b) com aumento de 2.000x a presença de vazios de tamanhos variados e um material menos orientado devido à dificuldade do processo de compactação de um material argiloso com teor de umidade muito baixo. As imagens das Figura 5.27(c) e Figura 5.27(d) com aumento maior de 8.000x evidenciam claramente uma textura mais floculada, com a presença de inúmeros vazios.

A composição química da amostra determinada pela sonda EDS está apresentada na Figura 5.28. O material é composto basicamente de $\mathrm{Si}, \mathrm{Al}, \mathrm{O}, \mathrm{Na}$, e Fe, que são os elementos comuns em argilominerais do grupo da esmectita.
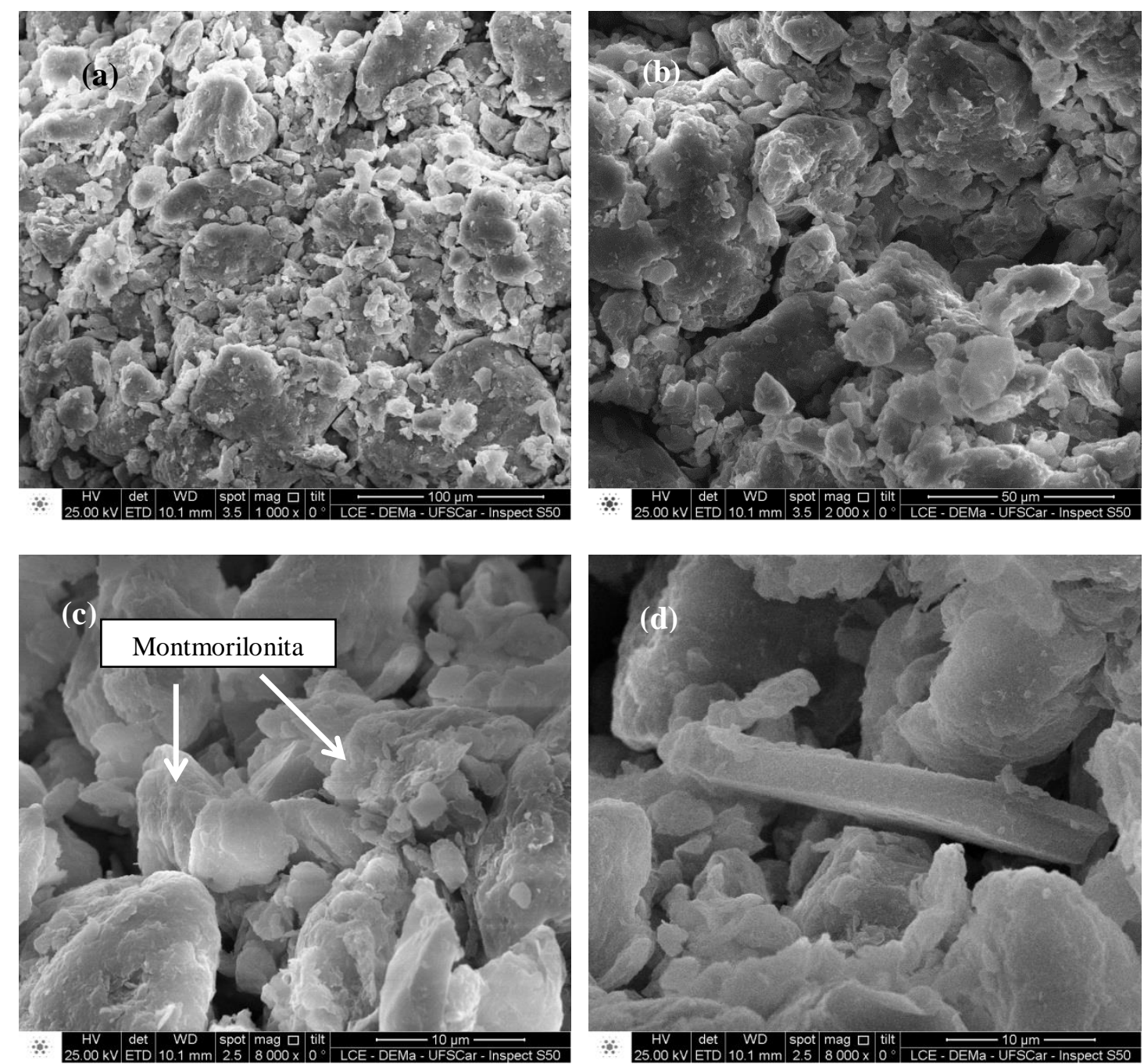

Figura 5.27 - Microscopia eletrônica de varredura da amostra de bentonita compactada antes do ensaio de expansão inundada. 


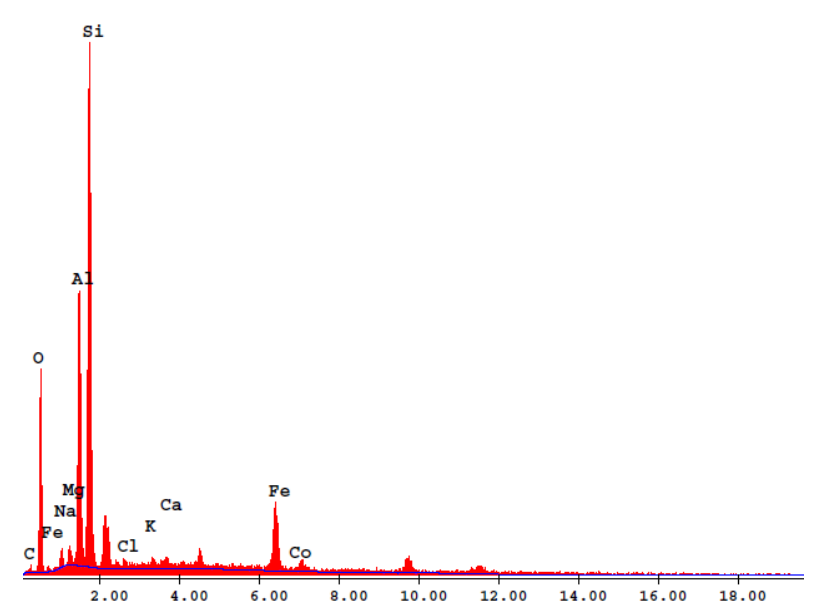

Figura 5.28 - Substâncias químicas constituintes na amostra de bentonita.

Para a mistura de material argiloso com $70 \%$ de bentonita, as imagens de MEV estão apresentadas na Figura 5.29. A mistura dos dois materiais apresenta fissuras antes mesmo de ser submetida ao ensaio de expansão, como mostra a Figura 5.29(a). Com um aumento de 2.000x (Figura 5.29(b)) nota-se a mistura dos materiais bem dispersos, com a presença de vazios de diferentes tamanhos. A Figura 5.29(c), em um aumento de 5.000x, ilustra a dificuldade de compactação dessas amostras e a grande quantidade de vazios presentes. $\mathrm{Na}$ Figura 5.29(d) observa-se a presença abundante de haloisita, que é um argilomineral do grupo da caulinita, evidenciada somente com aumento de 60.000x. 

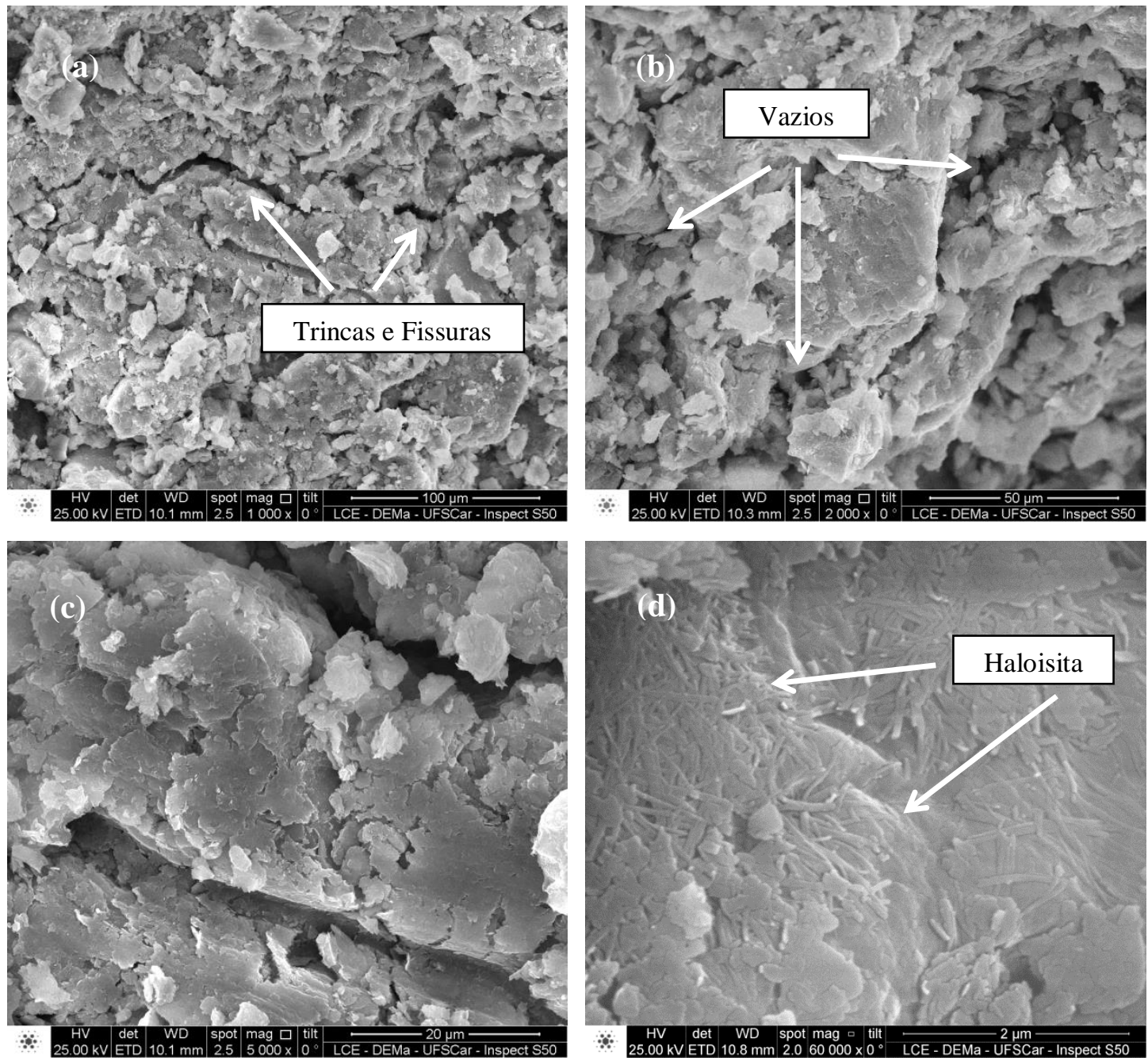

Figura 5.29 - Microscopia eletrônica de varredura da mistura de material argiloso com 70\% de bentonita.

A composição química da mistura de material argiloso com $70 \%$ de bentonita determinada pelo EDS está apresentada na Figura 5.30. A mistura é composta de $\mathrm{Si}, \mathrm{Al}, \mathrm{O}, \mathrm{Mg}, \mathrm{Na}$, e Fe, que são as elementos químicos comuns aos dois materiais. 


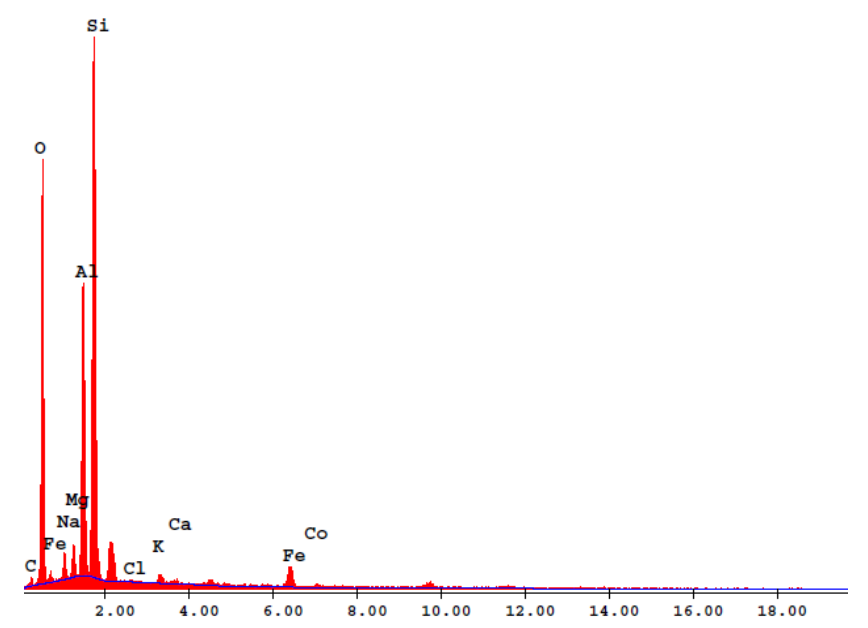

Figura 5.30 - Substâncias químicas constituintes na mistura de material argiloso com $70 \%$ de bentonita.

As imagens de MEV da mistura de material argiloso com 50\% de bentonita estão mostradas na Figura 5.31. É possível observar que a amostra apresenta inúmeros vazios diminutos nas imagens com aumento acima de 8.000x. Na Figura 5.31(a) nota-se o aspecto textural semelhante ao das outras amostras. A Figura 5.31(b) permite visualizar os diversos microvazios existentes na amostra em meio à montmorilonita dispersa. Em um aumento de 12.000x, a Figura 5.31(c) exibe com mais detalhe o aspecto dos vazios no interior da amostra, e na Figura 5.31(d) nota-se a presença da montmorilonita e de caulinita.

Para confirmar as substâncias presentes na mistura de material argiloso com $50 \%$ de bentonita, o EDS mostrado na Figura 5.32 determinou os mesmos elementos químicos evidenciados na mistura analisada anteriormente, porém, com uma inexpressiva diferença de porcentagens. 

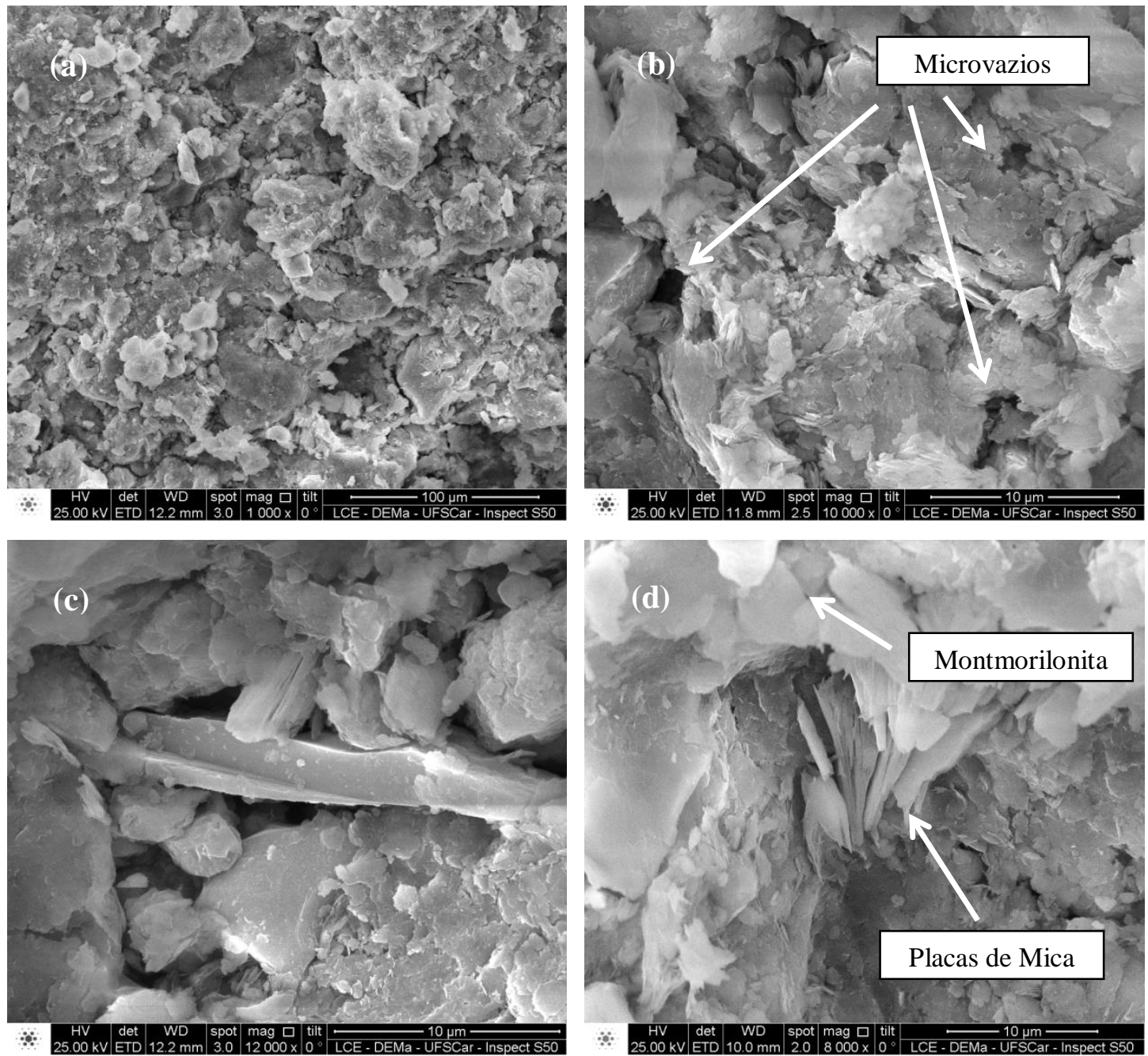

Figura 5.31 - Microscopia eletrônica de varredura da mistura de material argiloso com 50\% de bentonita.

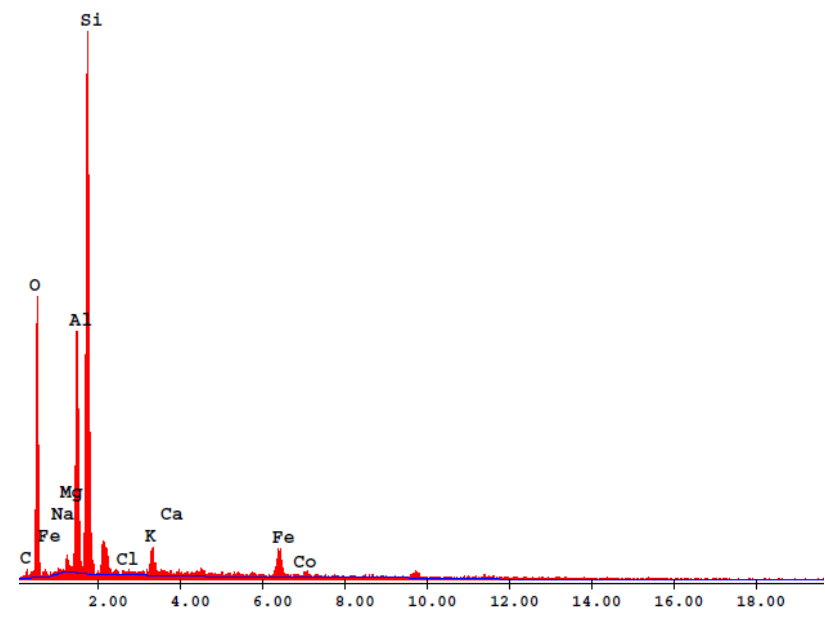

Figura 5.32 - Substâncias químicas constituintes na mistura de material argiloso com 50\% de bentonita. 
A Figura 5.33 mostra as análises de MEV feitas na mistura de material argiloso com $30 \%$ de bentonita. Nessa amostra, o aspecto poroso se torna mais fácil de visualizar quando se aumenta o nível de detalhamento da imagem. A textura da amostra pode ser observada na Figura 5.33(a) e (b), enquanto que na Figura 5.33(c) há uma concentração de caulinitas alocadas entre os micros vazios. Uma mistura dos argilominerais pode ser visualizada na Figura 5.33(d) com a presença de caulinita e montmorilonita.
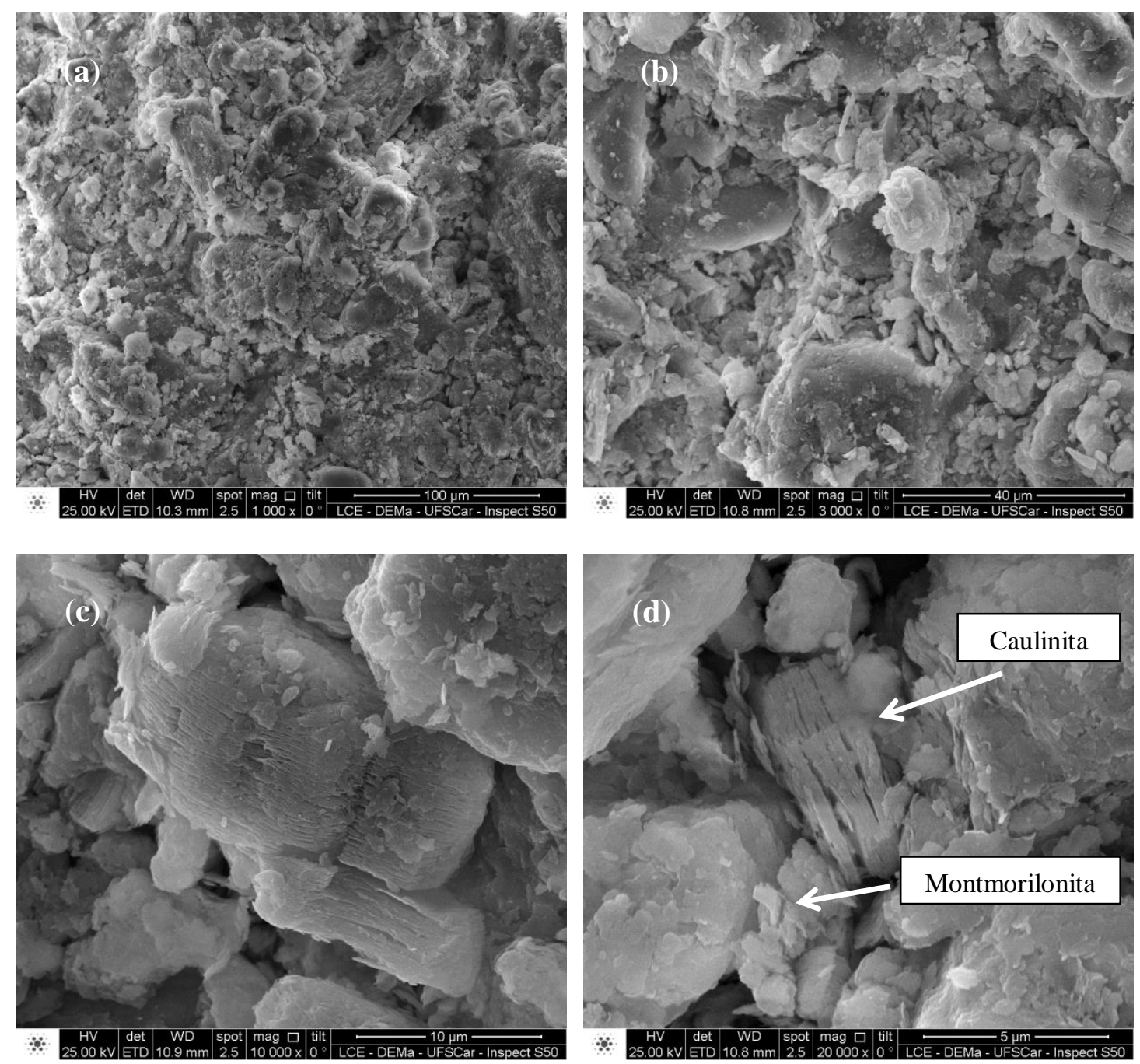

Figura 5.33 - Microscopia eletrônica de varredura da mistura de material argiloso com 30\% de bentonita.

A composição química desta mistura é apresentada na Figura 5.34 a titulo de confirmação das substâncias presentes no material ensaiado. Pode-se notar que foram determinadas as mesmas substâncias já identificadas anteriormente. 


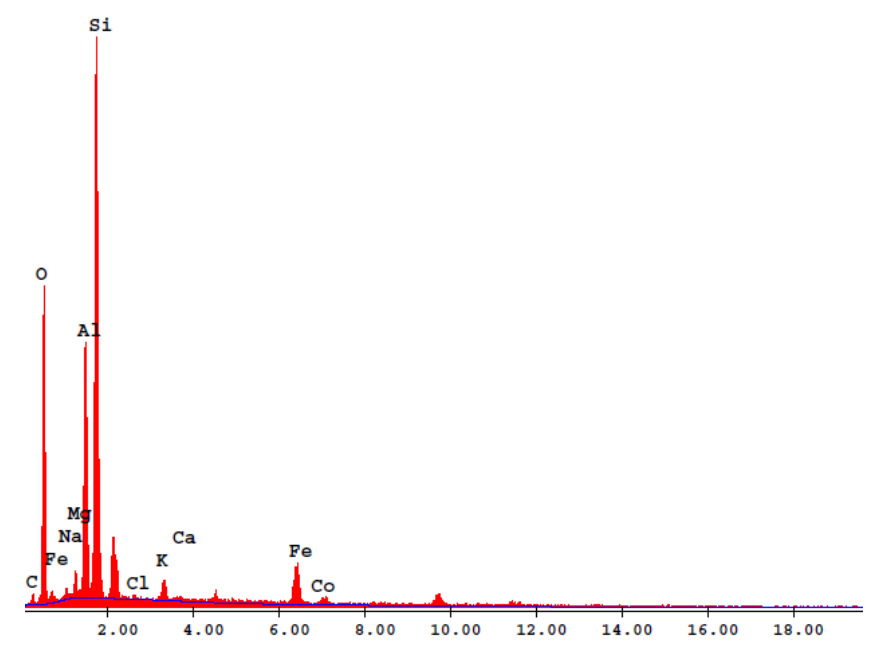

Figura 5.34 - Substâncias químicas constituintes na mistura de solo argiloso com $30 \%$ de bentonita.

Na Figura 5.35 têm-se as imagens de MEV da mistura de material argiloso com $10 \%$ de bentonita. A Figura 5.35(b) exibe uma textura empastilhada, com suspeita da presença de caulinita. Uma caulinita bem definida, e aparentemente não expandida, é mostrada na Figura 5.35(d) com um aumento de 20.000x. 

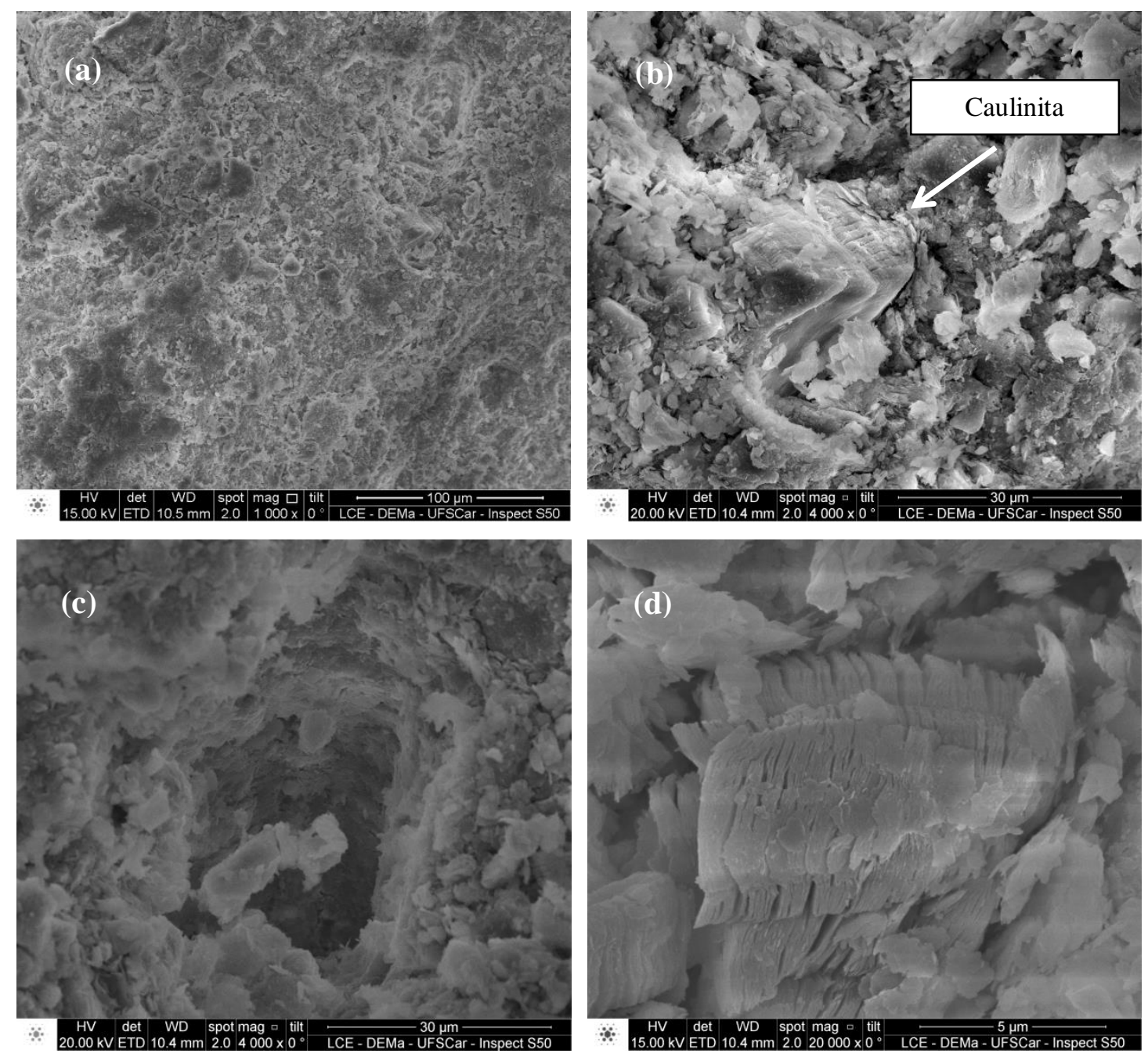

Figura 5.35 - Microscopia eletrônica de varredura da mistura de material argiloso com 10\% de bentonita.

A mistura de material argiloso com 5\% de bentonita não apresenta diferenças significativas nas imagens de MEV quando comparada à mistura com $10 \%$ de bentonita. Essas duas misturas apresentam semelhança com as imagens da amostra compactada na condição seca sem bentonita. Vale ressaltar, que essas duas misturas demonstraram pressões de expansão por inundação menor do que a pressão de expansão do solo compactado seco. Portanto, como evidenciado na porosimetria, as imagens do MEV também confirmam que os vazios não apresentaram variação significativa entre as amostras, bem como o aspecto textural mostrouse semelhante nas mesmas. A Figura 5.36 mostra a configuração da amostra de material argiloso com $5 \%$ de bentonita bem semelhante às comentadas anteriormente, com detalhes da textura na Figura 5.36(b), (c) e (d). 

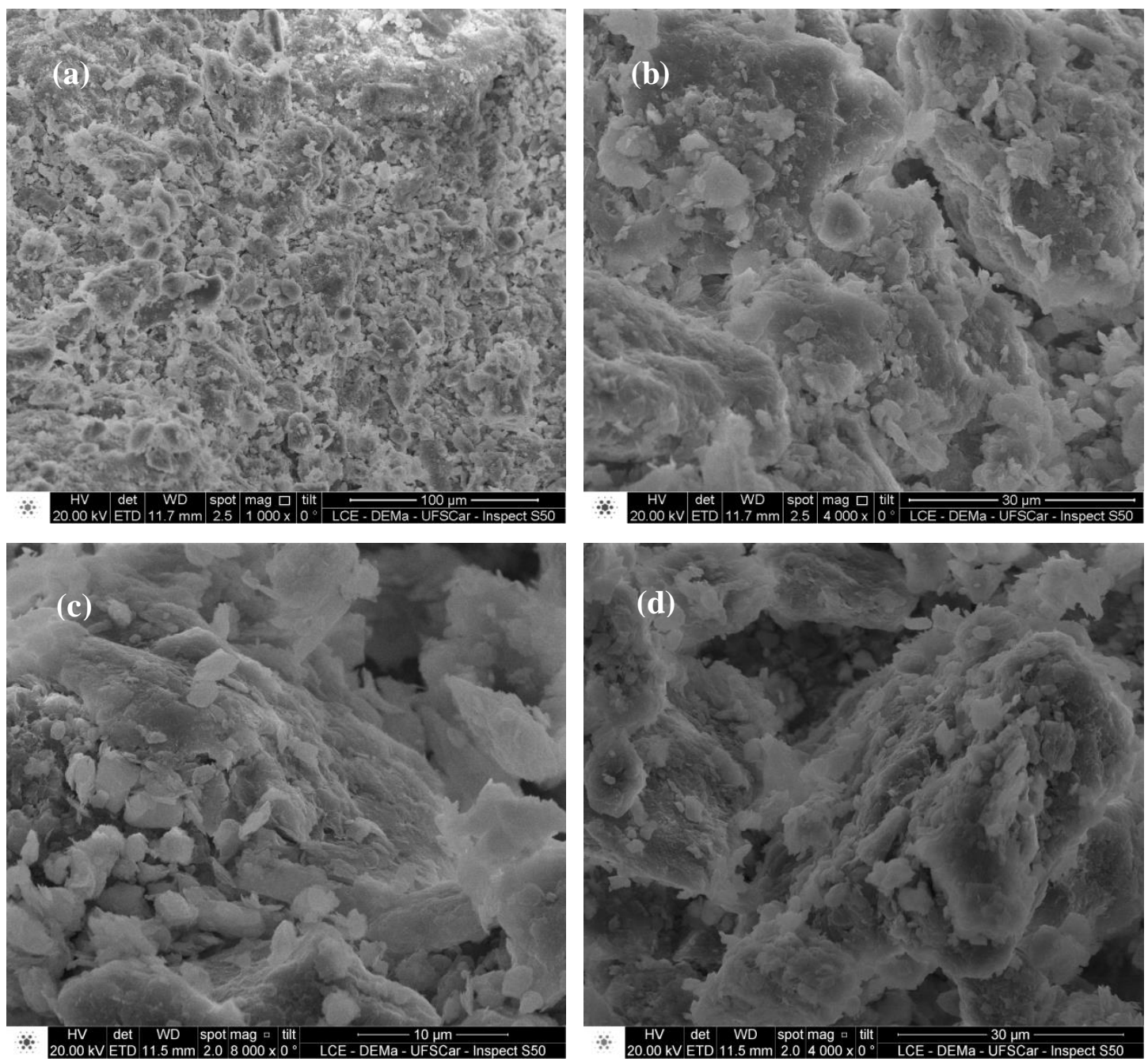

Figura 5.36 - Microscopia eletrônica de varredura da mistura de material argiloso com 5\% de bentonita.

5.1.3 Comportamento das Misturas de Material Arenoso da Formação Botucatu com Bentonita

Foram realizados ensaios em misturas de bentonita com material arenoso da Formação Botucatu, a fim de analisar a expansão da bentonita em misturas com materiais não expansivos. Isto foi realizado com o intuito de verificar o efeito isolado da bentonita sem que houvesse outros argilominerais presentes. Utilizaram-se misturas nas proporções de 30\%, $50 \%$ e $70 \%$ de bentonita com areia. Da mesma forma como se procederam com as misturas argilosas, essas misturas foram compactadas diretamente na célula edométrica com sucções iniciais calculadas em função das umidades relativas do ambiente da sala de ensaio, as quais variaram entre $40.000 \mathrm{kPa}$ e $66.000 \mathrm{kPa}$.

Como esperado, as pressões máximas de expansão variaram de 134 a $381 \mathrm{kPa}$, sendo estes valores crescentes correspondendo ao aumento na porcentagem de bentonita. Vale ressaltar 
que, além das porcentagens crescentes, as sucções iniciais das amostras apresentaram-se crescentes também, corroborando os resultados máximos de expansão. Os valores de pressão máxima de expansão para os mesmos teores de bentonita foram bem inferiores àqueles obtidos para as misturas com material argiloso da Formação Corumbataí. A redução da pressão de expansão se situou em 38\%, 41\% e 71\%, respectivamente para as misturas com 70, 50 e $30 \%$ de bentonita. Este comportamento denota a multiplicidade de fatores que interferem na expansão além da mineralogia da fração argila.

Os índices físicos iniciais das amostras apresentaram consistência, com densidade aparente seca maior e índice de vazios menor para baixas porcentagens de bentonita. Assim como, baixo teor de umidade, visto que o material absorve umidade em grandes proporções à medida que se aumenta a quantidade de bentonita na mistura.

\subsubsection{Distribuição de Poros - Mistura de Material Arenoso com Bentonita}

Para esta condição, a porosimetria também foi realizada apenas nas amostras antes do ensaio de expansão. A Figura 5.37 apresenta a porosimetria da mistura arenosa com $70 \%$ de bentonita; a Figura 5.38 da mistura arenosa com 50\% de bentonita; a Figura 5.39 da mistura arenosa com $30 \%$ de bentonita.

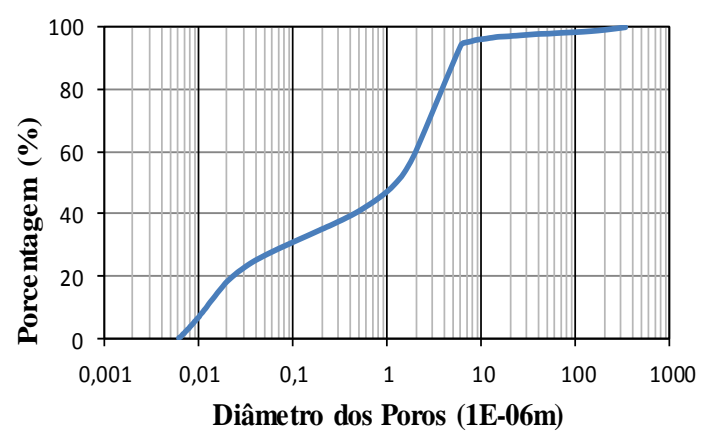

(a)

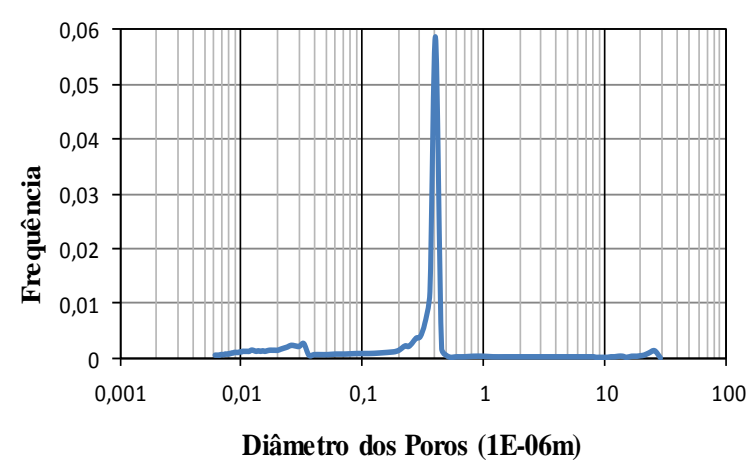

(b)

Figura 5.37 - Porosimetria por intrusão de mercúrio para amostra arenosa com $70 \%$ bentonita compactada seca ao ar: (a) Porcentagem versus diâmetro dos poros; (b) Frequência dos intervalos de diâmetros. 


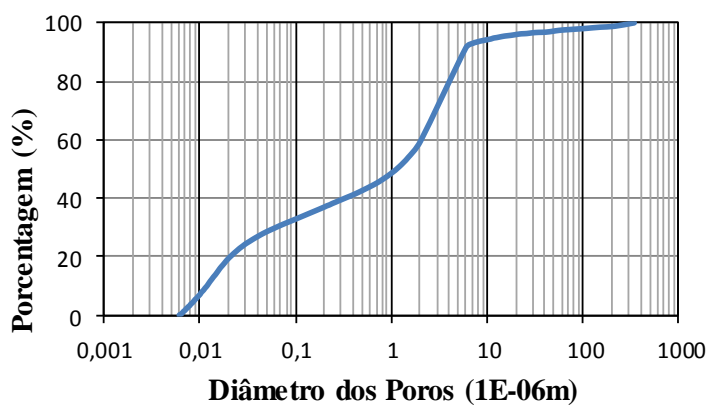

(a)

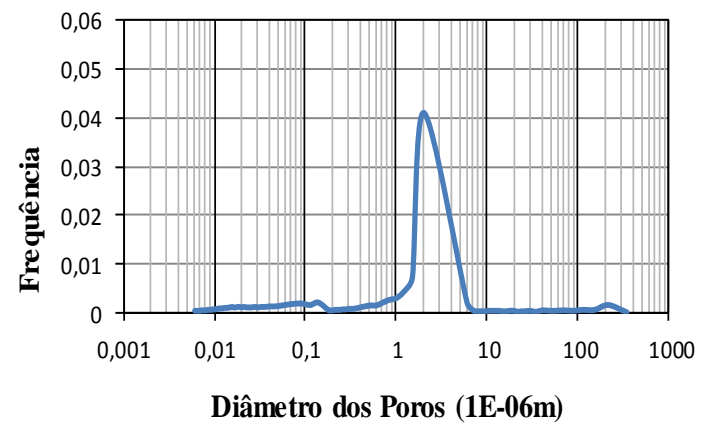

(b)

Figura 5.38 - Porosimetria por intrusão de mercúrio para amostra arenosa com 50\% bentonita compactada seca ao ar: (a) Porcentagem versus diâmetro dos poros; (b) Frequência dos intervalos de diâmetros.

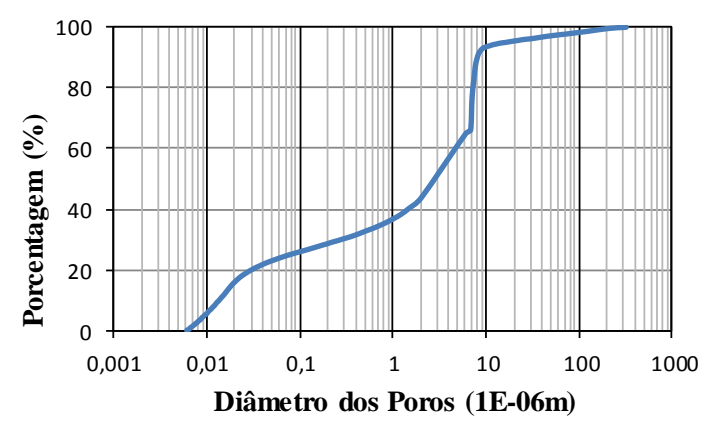

(a)

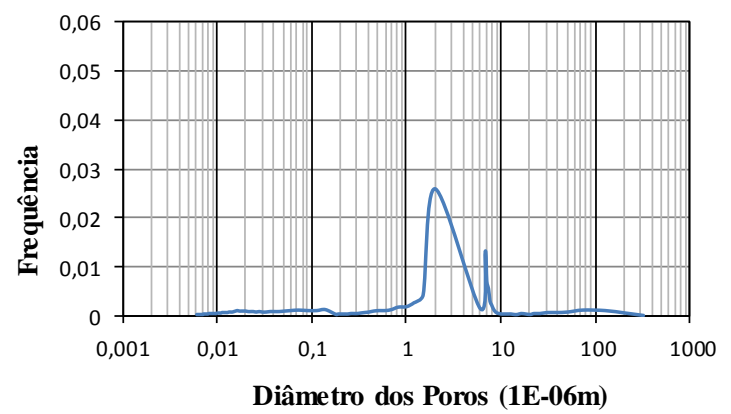

(b)

Figura 5.39 - Porosimetria por intrusão de mercúrio para amostra arenosa com 30\% bentonita compactada seca ao ar: (a) Porcentagem versus diâmetro dos poros; (b) Frequência dos intervalos de diâmetros.

Pode-se notar que as curvas de distribuição dos poros apresentaram-se, de maneira geral, unimodais. A mistura de $30 \%$ de bentonita apresentou comportamento anômalo aos demais. Provavelmente ocorreu algum problema no momento do experimento, o que impossibilitou a determinação com exatidão da curva de distribuição dos poros.

A frequência maior de poros de diâmetro de $0,6 \mu \mathrm{m}$ foi observada na mistura de $70 \%$ de bentonita, com um pico bem acentuado, caracterizando a amostra com poros de tamanho uniforme. Nas outras situações é possível verificar essa mesma observação, porém, com picos menos acentuados (frequências menores) e intervalos de diâmetro maiores.

Na Tabela 5.9 podem ser visualizadas as porcentagens de distribuição de poros das misturas arenosas com bentonita somente para a condição antes da inundação. Mais uma vez constatase que há presença maior de macroporos nas amostras. As misturas arenosas com bentonita apresentam uma distribuição peculiar à medida que a porcentagem da mistura aumenta, como 
por exemplo, a amostra com $30 \%$ de bentonita mostra porcentagem de macroporo menor do que a amostra com $70 \%$ de bentonita. Pode-se afirmar que o material arenoso não tem função física, ou seja, não promove expansão, apenas desempenha o papel de esqueleto. No entanto, esse material tem influência no arranjo e distribuição das partículas de bentonita no interior da amostra.

Tabela 5.9 - Porcentagem de distribuição de poros das amostras arenosas compactadas da Formação Botucatu misturadas com bentonita

\begin{tabular}{|c|c|c|c|}
\hline \multicolumn{4}{|c|}{ Distribuição dos Poros por Diâmetro (\%) } \\
\hline \multirow{2}{*}{ Amostras } & \multicolumn{3}{|c|}{ IUPAC (1985) } \\
\cline { 2 - 4 } & $\begin{array}{c}\text { Micro e Meso } \\
0,002<\varnothing<0,05 \mu \mathrm{m}\end{array}$ & $\begin{array}{c}\text { Macro } \\
0,05<\varnothing<7,5 \mu \mathrm{m}\end{array}$ & $\begin{array}{c}\text { Mega } \\
\varnothing>7,5 \mu \mathrm{m}\end{array}$ \\
\hline Arenosa + 70\% Bentonita & 26,82 & 68,55 & 4,63 \\
\hline Arenosa + 50\% Bentonita & 28,77 & 64,47 & 6,76 \\
\hline Arenosa + 30\% Bentonita & 23,12 & 59,32 & 17,56 \\
\hline
\end{tabular}

A Tabela 5.10 mostra as porosidades calculadas e as porosidades determinadas pelo PIM para as misturas de material arenoso com bentonita. Nestas condições, todas as porosidades determinadas pela PIM foram menores em relação às porosidades calculadas pelos índices físicos das amostras. Pode-se afirmar que o arranjo formado entre os grãos do material arenoso e a bentonita foi mais homogêneo, apresentando certa retração à injeção do mercúrio, impossibilitando atingir os microporos das amostras.

Tabela 5.10 - Comparação entre porosidade calculada e a porosidade determinada pela PIM para as amostras arenosas compactadas da Formação Botucatu misturadas com bentonita.

\begin{tabular}{|c|c|c|}
\hline \multirow{2}{*}{ Amostra } & \multicolumn{2}{|c|}{ Porosidade (\%) } \\
\cline { 2 - 3 } & $\boldsymbol{\eta}_{\text {calc. }}$ & $\boldsymbol{\eta}_{\text {PIM }}$ \\
\hline Arenoso $+70 \%$ & 44,34 & 29,71 \\
\hline Arenoso $+50 \%$ & 37,59 & 23,19 \\
\hline Arenoso $+30 \%$ & 34,28 & 23,84 \\
\hline
\end{tabular}

\subsubsection{Microscopia Eletrônica de Varredura - Mistura Arenosa com Bentonita}

As misturas arenosas com bentonita também foram analisadas por microscopia eletrônica de varredura apenas na situação antes dos ensaios de expansão inundada. Verifica-se uma diferença considerável na textura dessas misturas em relação às misturas de solo argiloso com bentonita. As partículas mais grossas da areia são evidenciadas facilmente já em um amento de 1.000x nas imagens. Nota-se também, que as partículas finas de bentonita aderiram na superfície das partículas de areia. Verifica-se nas imagens que o aumento da porcentagem de 
bentonita originou a formação de micro vazios nas amostras, o que pode ter influenciado no aumento na pressão de expansão, visto que os resultados foram gradativamente elevados.

A Figura 5.40 apresenta as imagens de MEV para a mistura arenosa com $70 \%$ de bentonita, na qual observa-se a textura da amostra em diferentes aumentos. A Figura 5.41 mostra a composição química média na amostra.
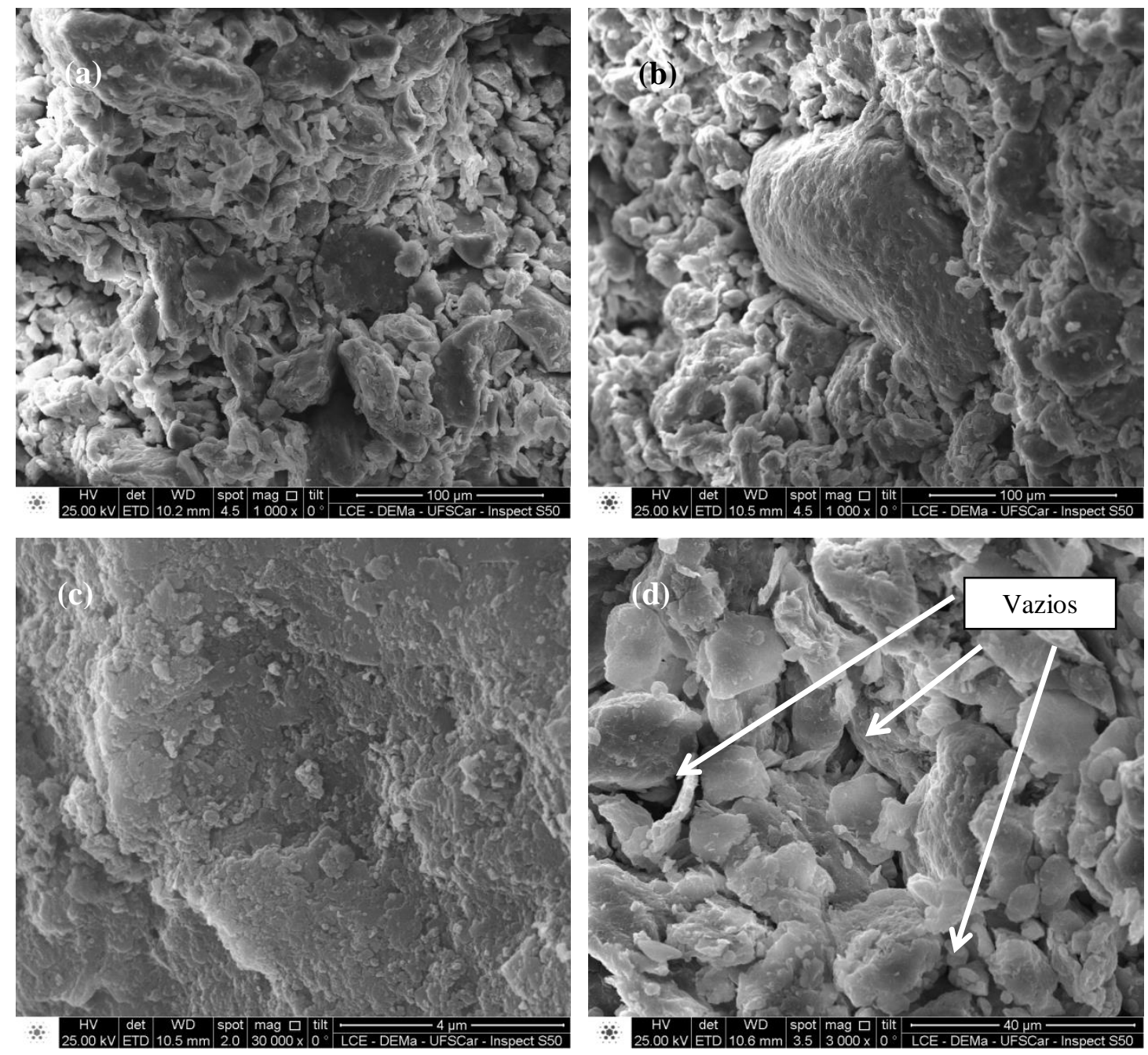

Figura 5.40 - Microscopia eletrônica de varredura da mistura arenosa com 70\% de bentonita. 


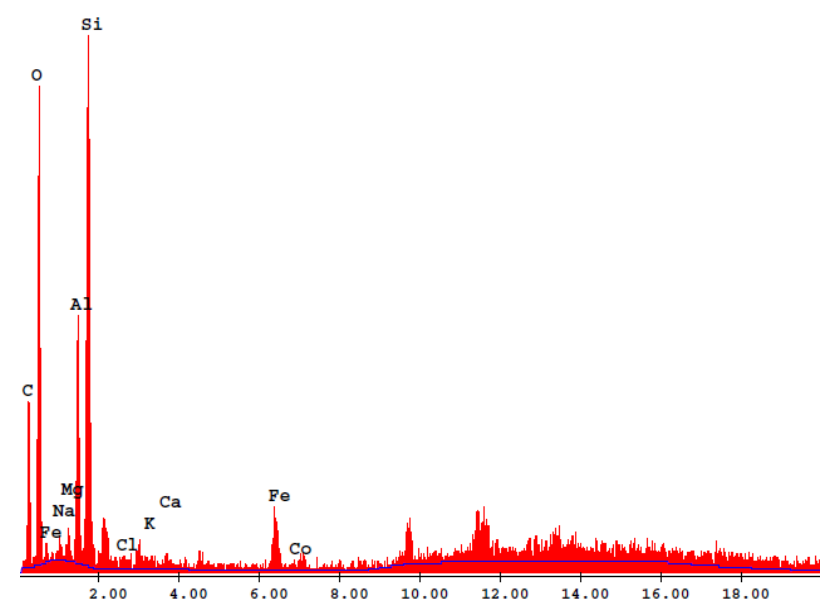

Figura 5.41 - Substâncias químicas constituintes na mistura arenosa com $70 \%$ de bentonita.

A textura da mistura arenosa com $70 \%$ de bentonita pode ser visualizada na Figura 5.40(a) e (b). Nota-se nestas imagens a diferença de estrutura dessa mistura comparada aos materiais já analisados. A textura da bentonita aderida nas partículas de areia pode ser vista na Figura 5.40(c). A Figura 5.40(d) apresenta em detalhe os dos micros vazios existentes na amostra. Em relação à composição química, a mistura de areia com bentonita compreende porcentagens de $\mathrm{Si}, \mathrm{O}, \mathrm{Al}, \mathrm{Mg}, \mathrm{Na}$ e $\mathrm{Fe}$.

A mistura arenosa com 50\% de bentonita é apresentada na Figura 5.42. Nesta condição, percebe-se que os vazios tornam-se maiores quando é reduzida a porcentagem de bentonita na mistura, como mostra a Figura 5.42(b) com mesmo aumento da Figura 5.40(d). A Figura 5.42 (c) exibe uma partícula de areia envolvida por bentonita, e a Figura 5.42(d) mostra o argilomineral montmorilonítico da bentonita disperso em um vazio de maior dimensão.

A composição química determinada pelo EDS é confirmada no diagrama espectral apresentado na Figura 5.43. Os elementos químicos encontrados para essa mistura foram $\mathrm{Si}$, $\mathrm{O}, \mathrm{Al}, \mathrm{Mg}, \mathrm{Na}, \mathrm{Fe}$ dentre outros em pequenas porcentagens. 

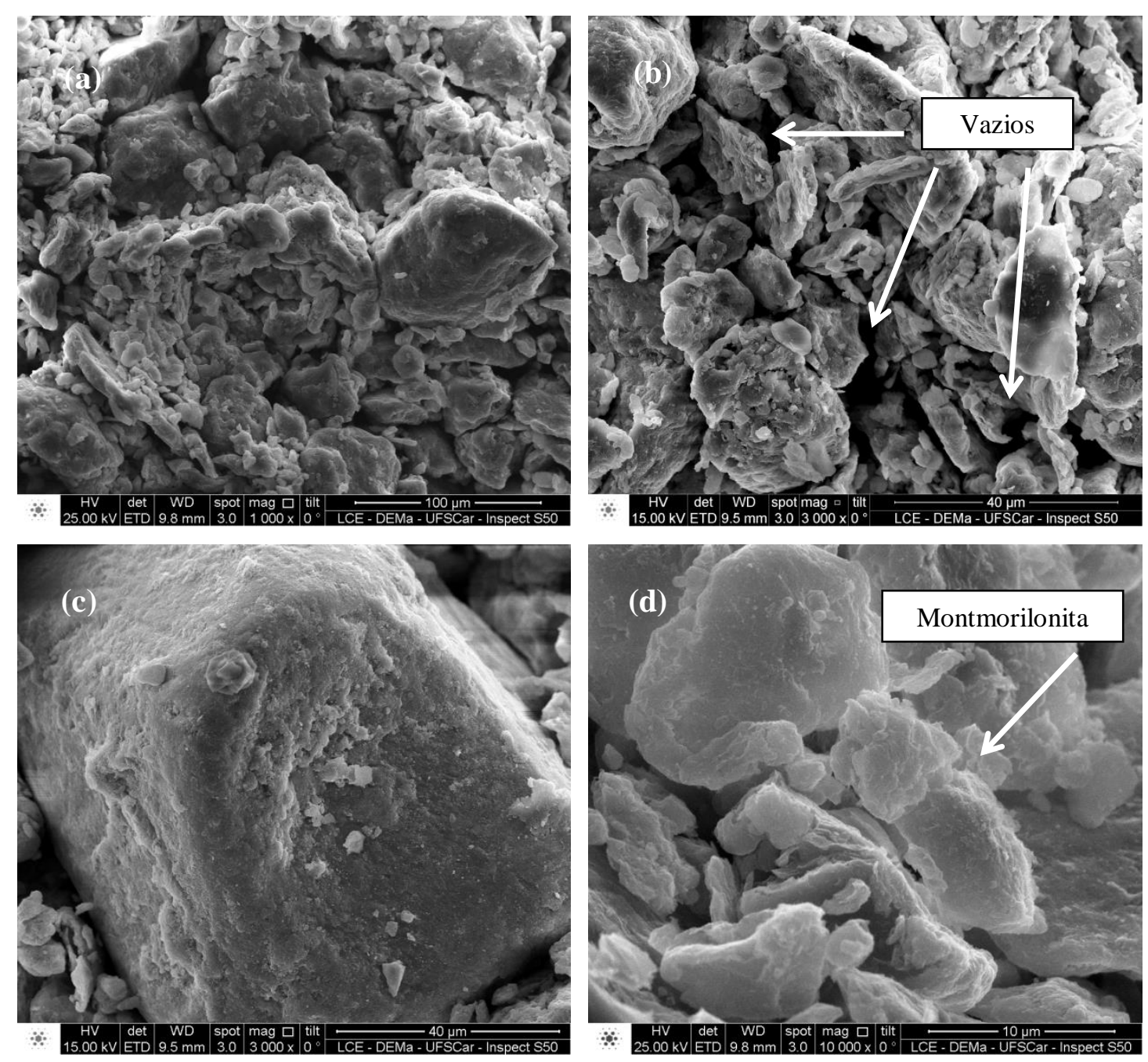

Figura 5.42 - Microscopia eletrônica de varredura da mistura arenosa com 50\% de bentonita.

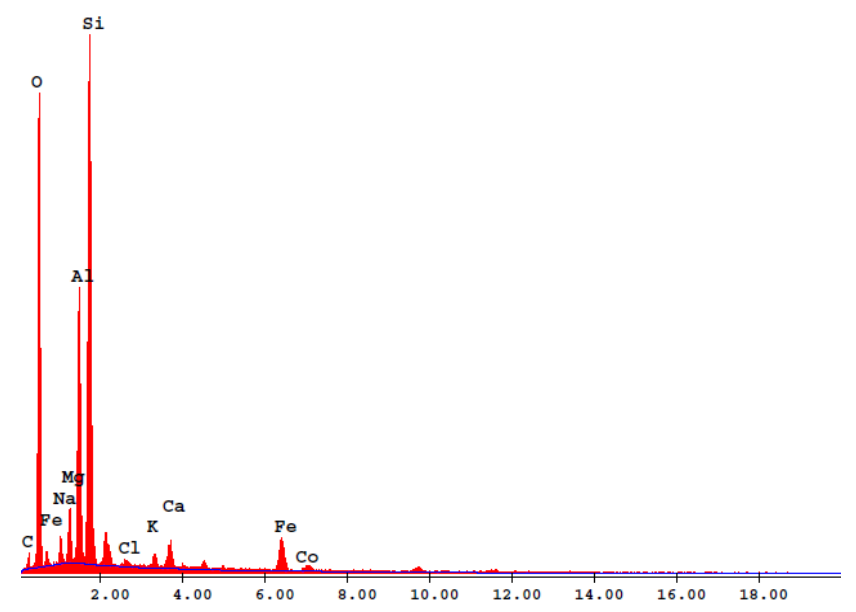

Figura 5.43 - Substâncias químicas constituintes na mistura arenosa com 50\% de bentonita. 
No MEV da mistura arenosa com 30\% de bentonita (Figura 5.44) constata-se novamente a presença de vazios de maiores dimensões no interior da amostra, como pode ser visto na Figura 5.44(a). A Figura 5.44(b) mostra a textura da amostra em um aumento de 5.000x, as Figura 5.44(c) e (d) mostram imagens com aumentos maiores configurando a floculação do material, e inúmeros vazios.

A Figura 5.45 apresenta o EDS da mistura com a determinação dos mesmos elementos químicos das misturas anteriores, porém, em diferentes porcentagens obedecendo a diminuição das porcentagens dos elementos presentes na bentonita.
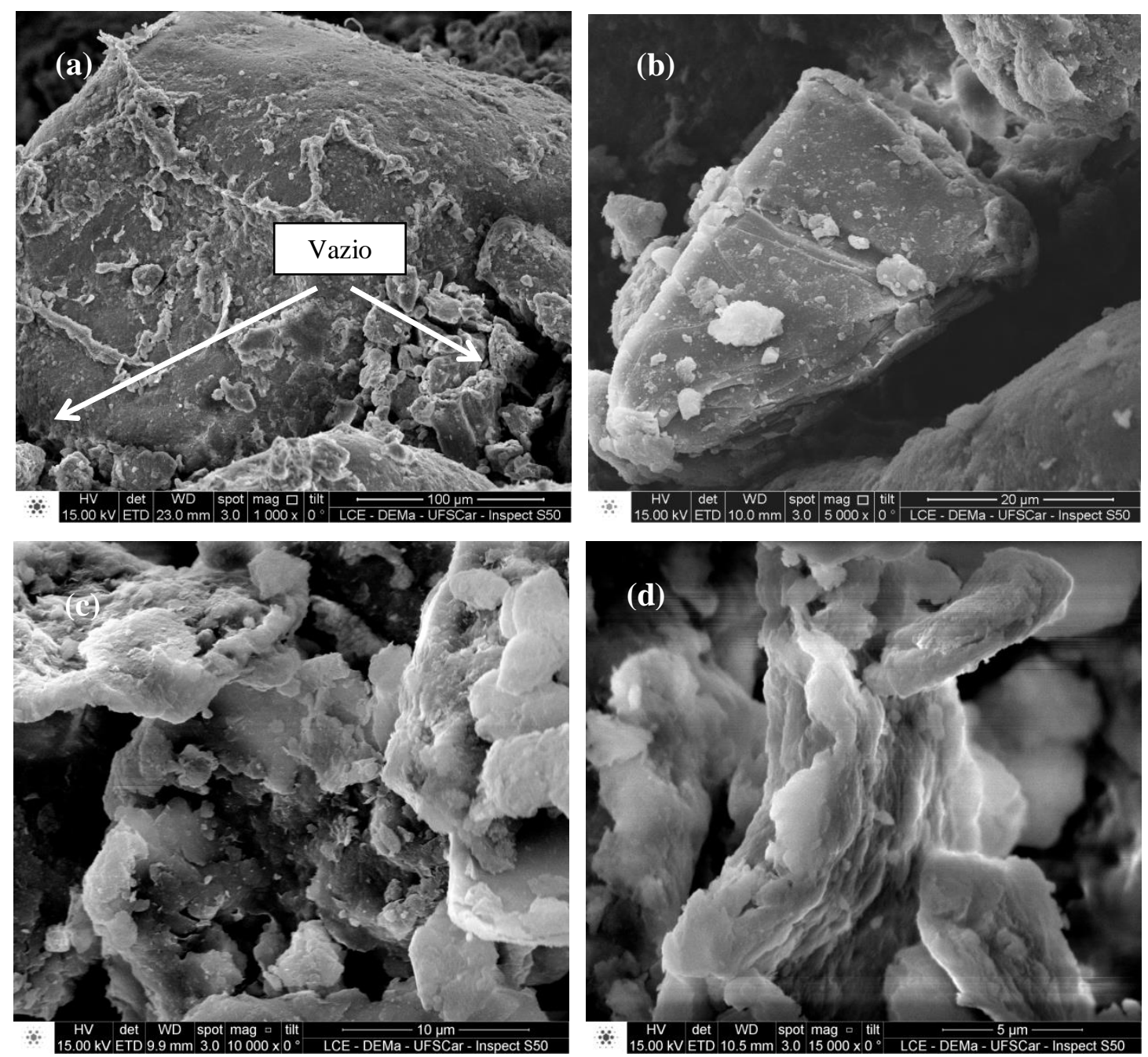

Figura 5.44 - Microscopia eletrônica de varredura da mistura arenosa com 30\% de bentonita. 


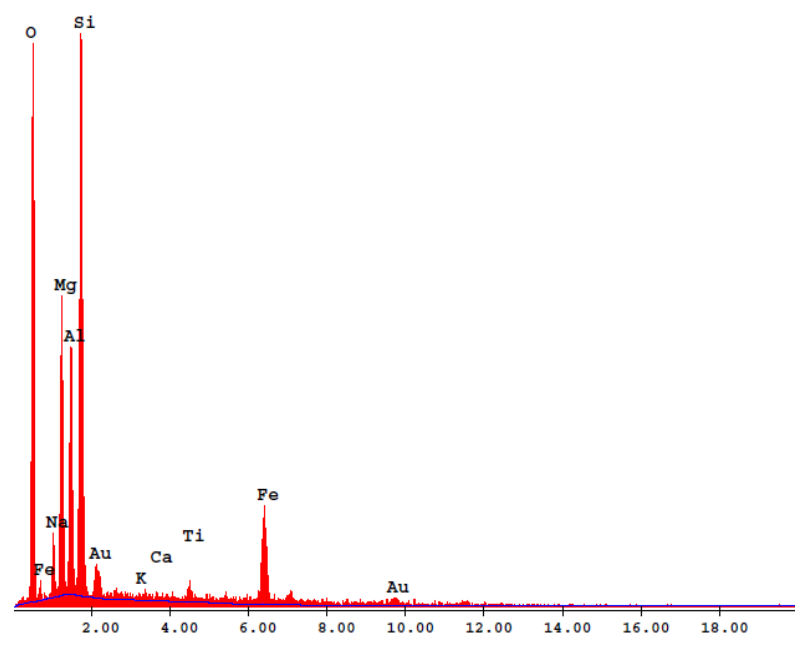

Figura 5.45 - Substâncias químicas constituintes na mistura arenosa com 30\% de bentonita.

\subsubsection{Comparação entre as Misturas de Material Argiloso e Material Arenoso com Bentonita}

O material argiloso sem argilomineral expansivo quando em contato com a bentonita revela pressões de expansão bem mais expressivas em relação às misturas de bentonita com material arenoso. Mais uma vez, vale ressaltar que a sucção inicial dessas misturas argilosas com bentonita foi mais elevada e, portanto, essa diferença entre o comportamento expansivo está relacionada, não somente com o argilomineral, mas também, com as condições iniciais da amostra.

As curvas de distribuição de poros nas misturas argilosas apresentam tendência a bimodalidade, revelando dois tamanhos de poros, enquanto que nas curvas das misturas de solo arenoso exibiram aparência unimodal, com poros de mesmo tamanho. Este fato pode ser explicado pela forma de acomodação das partículas coloidais de montmorilonita presente na bentonita nos vazios formados na superfície das partículas de areia.

Tien et al. (2004) comenta que misturas de material argiloso e arenoso podem ser consideradas como uma espécie de material compósito. A argila pode ser tratada como uma matriz, e a areia pode ser considerada como uma inclusão. A partir dessa afirmação, pode dizer que a inclusão da areia promoveu uma melhor acomodação no arranjo entre os materiais. 


\subsection{Ensaios de Expansão com a Técnica da Transferência de Vapor}

\subsubsection{Resultados das Amostras que não Apresentaram Expansão}

Foram realizados ensaios com imposição de umidade relativa em amostras indeformadas e compactadas na umidade ótima, ambas secas ao ar. Para diferentes situações de ensaio, as amostras não demonstraram expansão, porém, apresentaram ganho de umidade e variação no teor de umidade. As condições de amostras ensaiadas estão apresentadas na Tabela 5.11.

Tabela 5.11 - Tipos de amostras e condições de ensaios que não houve expansão.

\begin{tabular}{|l|c|}
\hline \multicolumn{2}{|c|}{ Tipo de Amostra Ensaiada } \\
\hline AM. 01 & Amostra Indeformada \\
\hline AM. 02 & Amostra compactada na Wót e depois seca ao ar, ensaiada sem bomba de circulação \\
\hline AM. 03 & Amostra compactada na Wót e depois seca ao ar, ensaiada com bomba de circulação \\
\hline AM. 04 & Amostra compactada na Wót e depois seca ao ar, ensaiada com bomba e circulação na pedra inferior \\
\hline AM. 05 & Amostra compactada na Wót e depois seca ao ar, ensaiada na prensa de adensamento \\
\hline
\end{tabular}

Foram realizados ensaios com amostra argilosa da Formação Corumbataí em diferentes condições, como mostrado na Tabela 5.11. Variou-se, também, a forma de imposição de umidade, com auxílio de bomba de circulação de vapor, e sem o auxílio da mesma. Utilizouse, ainda, a prensa de adensamento para realização dos testes. Todos os ensaios foram conduzidos até a estabilização da sucção imposta desejada de $5.000 \mathrm{kPa}$ controlada pela umidade relativa no interior da célula edométrica de ensaio.

Os índices físicos das amostras ensaiadas são mostrados na Tabela 5.12. Após os ensaios foram calculados novamente todos os índices físicos, que estão apresentados na Tabela 5.13.

Tabela 5.12 - Índices físicos das amostras antes dos ensaios.

\begin{tabular}{|c|c|c|c|c|c|c|c|c|}
\hline Amostras & $\begin{array}{c}\text { Massa g } \\
(\mathbf{s o l o})\end{array}$ & $\begin{array}{c}\mathbf{w} \\
(\boldsymbol{\%})\end{array}$ & $\begin{array}{c}\mathbf{\rho} \\
\mathbf{g} / \mathbf{c m}^{\mathbf{3}}\end{array}$ & $\begin{array}{c}\mathbf{\rho}_{\mathbf{d}} \\
\mathbf{g} / \mathbf{c m}^{\mathbf{3}}\end{array}$ & $\begin{array}{c}\mathbf{\rho}_{\mathbf{s}} \\
\mathbf{g} / \mathbf{c m}^{\mathbf{3}}\end{array}$ & $\begin{array}{c}\mathbf{e} \\
-\end{array}$ & $\begin{array}{c}\mathbf{n} \\
\mathbf{\%}\end{array}$ & $\begin{array}{c}\mathbf{S r} \\
\mathbf{\%}\end{array}$ \\
\hline AM. 01 & 110,16 & 0,95 & 1,70 & 1,68 & 2,69 & 0,60 & 0,37 & 4,27 \\
\hline AM. 02 & 121,98 & 3,61 & 1,68 & 1,62 & 2,69 & 0,66 & 0,40 & 14,74 \\
\hline AM. 03 & 122,45 & 4,16 & 1,67 & 1,60 & 2,69 & 0,68 & 0,40 & 16,47 \\
\hline AM. 04 & 122,20 & 3,65 & 1,67 & 1,62 & 2,69 & 0,67 & 0,40 & 14,75 \\
\hline AM. 05 & 121,32 & 3,53 & 1,57 & 1,52 & 2,69 & 0,77 & 0,44 & 12,30 \\
\hline
\end{tabular}


Tabela 5.13 - Índices físicos das amostras após o ensaio.

\begin{tabular}{|c|c|c|c|c|c|c|c|c|}
\hline Amostras & $\begin{array}{c}\text { Massa g } \\
\text { (solo) }\end{array}$ & $\begin{array}{c}\mathbf{w} \\
(\%)\end{array}$ & $\begin{array}{c}\rho \\
\mathrm{g} / \mathrm{cm}^{3}\end{array}$ & $\begin{array}{c}\rho_{d} \\
\mathrm{~g} / \mathrm{cm}^{3}\end{array}$ & $\begin{array}{c}\rho_{\mathrm{s}} \\
\mathrm{g} / \mathrm{cm}^{3}\end{array}$ & $\begin{array}{l}\text { e } \\
- \\
\end{array}$ & $\begin{array}{l}\text { n } \\
\%\end{array}$ & $\begin{array}{l}\mathrm{Sr} \\
\% \\
\end{array}$ \\
\hline AM. 01 & 117,30 & 7,45 & 1,81 & 1,68 & 2,69 & 0,60 & 0,37 & 33,51 \\
\hline AM. 02 & 127,68 & 8,39 & 1,76 & 1,62 & 2,69 & 0,66 & 0,40 & 34,30 \\
\hline AM. 03 & 130,16 & 10,39 & 1,77 & 1,61 & 2,69 & 0,67 & 0,40 & 41,45 \\
\hline AM. 04 & 128,78 & 9,31 & 1,63 & 1,49 & 2,69 & 0,80 & 0,45 & 31,14 \\
\hline AM. 05 & 128,87 & 9,40 & 1,67 & 1,53 & 2,69 & 0,76 & 0,43 & 33,15 \\
\hline
\end{tabular}

As umidades medidas nas amostras após os ensaios não apresentaram diferença no intervalo de porcentagem para os diferentes modos de umedecimento, seja por circulação de vapor de água forçada através de uma bomba de ar; circulação por bomba com conexão acoplada diretamente na pedra porosa inferior; ou simplesmente sem bomba como utilizado por Pereira (2004). No entanto, o tempo para se atingir a umidade correspondente à sucção imposta foi menor quando se utilizou a circulação de vapor, correspondendo a 30 dias aproximadamente.

As densidades secas dessas amostras compactadas, comparadas com as densidades secas das amostras submetidas à expansão por inundação são de maior valor, com índice de vazios menor, e mesmo assim não expandiram. Ou seja, a variação dos índices físicos não influenciou no comportamento expansivo. Dessa forma, a distribuição dos poros, mais uma vez confirma, que as amostras não sofreram variação de poros após o ensaio. Pode-se concluir que os índices físicos iniciais das amostras não influenciaram a fim de promover expansão nos corpos de prova.

As sucções iniciais das amostras foram calculadas com base na temperatura ambiente e umidade relativa do ar de acordo com a metodologia proposta por Fredlund e Rahardjo (1993) e são mostradas na Tabela 5.14.

Tabela 5.14 - Sucção inicial das amostras sem expansão.

\begin{tabular}{|c|c|}
\hline Amostra & Sucção Inicial (MPa) \\
\hline AM. 01 & 49 \\
\hline AM. 02 & 22 \\
\hline AM. 03 & 14 \\
\hline AM. 04 & 19 \\
\hline AM. 05 & 45 \\
\hline
\end{tabular}

Os intervalos de sucção não foram suficientemente elevados para que promovessem uma maior capacidade de absorção de água, com exceção da AM.01 e AM.05 que já mostram valores mais expressivos. Então, esse ganho de umidade pode confirmar o que alguns autores na literatura, como Popescu (1986), justificam a expansão como sendo dividida em 
intercristalina e intracristalina. Neste caso, pode ter ocorrido a não expansão intercristalina. Esse tipo de expansão é oriunda da ação da umidade residual constituída nos materiais secos que são capazes de produzir forças capilares unindo as partículas, e à medida que ocorre o umedecimento essas forças relaxam e a argila expande. Porém, nesta pesquisa as amostras absorveram umidade sob forças capilares, mas não suficientes para expandir. Já nos ensaios inundados, o umedecimento de forma rápida promoveu o relaxamento dessas forças, e as amostras pronunciaram um comportamento expansivo.

Pereira (2004) realizou diversos ensaios em edômetros com imposição de umidade relativa com amostras indeformadas nas condições seca ao ar, natural e estabilizada em níveis de sucção que variaram entre 40.000 e $1.000 \mathrm{kPa}$. As expansões foram nulas para os ensaios conduzidos com a imposição de umidade relativa, enquanto que para os ensaios na condição inundada as pressões de expansão foram expressivas com valores de $3.000 \mathrm{kPa}$. A autora relata que este fato poderia ter ocorrido devido à variação de umidade entre os estágios de sucção não terem sido suficientes para gerar pressões de expansão. Testes adicionais foram realizados introduzindo amostras com sucção inicial estabilizada em $40.000 \mathrm{kPa}$ para atingir umidades para sucção de $1.000 \mathrm{kPa}$ com procedimentos de ensaio similares aos anteriores. Os resultados desses novos testes revelaram pressões nulas novamente. Assim sendo, a autora concluiu que a não expansão poderia estar relacionada com a lenta mudança de umidade por meio da transferência de água na fase de vapor, podendo interferir no comportamento das amostras.

Nesta pesquisa, os testes foram conduzidos em amostras indeformadas e compactadas que já haviam demonstrado expansão nos ensaios inundados. O contraste da umidade se deu com sucção inicial mais elevada em contato com solução salina de $5.000 \mathrm{kPa}$, ou seja, amostras mais secas foram colocadas em atmosferas mais úmidas.

A ausência de pressão de expansão relaciona-se com a velocidade de umedecimento, que não se traduz em forças suficientes para que o solo possa reagir com expansão. A água intersticial consegue atingir os poros de tamanho maior, justificando o ganho de umidade, mas não consegue atingir os poros de tamanho menor. Isso impossibilita que forças de repulsão sejam geradas por reações físico-químicas entre a superfície das partículas de argila e as moléculas de água. 
Wayllace (2008) comenta que a expansão cristalina é um mecanismo que ocorre de forma microescalar contemplando a hidratação, efeitos de capilaridade e osmose. É sabido que a hidratação está intimamente ligada com a disponibilidade de água no sistema solo-água; a capilaridade com o efeito de matriz do solo e a osmose com atração de moléculas de água por meio das forças elétricas das superfícies das partículas. $\mathrm{O}$ autor relata que os meniscos capilares ocorrem, geralmente, nos poros de maior tamanho, e estão mais predispostos a atuar, apenas, como fornecedores de água para os outros poros que estão a curto alcance pelo menisco de adsorção.

Dessa forma, pode-se fazer uma referência aos ensaios que não expandiram nesta pesquisa, considerando que os poros de tamanho micro escalar das amostras compactadas na umidade ótima e das indeformadas, posteriormente secas ao ar, não foram abastecidos de água. $\mathrm{Ou}$ seja, as amostras ganharam umidade nos poros maiores, porém, não suficientes para distribuir aos poros menores a fim de promover a variação volumétrica.

\subsubsection{Resultados das Amostras que Apresentaram Expansão}

Como visto no item anterior, foram realizadas inúmeras tentativas para que fossem obtidos resultados de expansão através da técnica da transferência de vapor em amostras argilosas indeformadas e compactadas da Formação Corumbataí. Este objetivo implicou em analisar não somente o desempenho do equipamento desenvolvido na pesquisa, mas também, o comportamento expansivo dessas amostras com esta técnica.

O resultado de expansão desse material para as condições expostas anteriormente foram nulos. Então, na tentativa de verificar qual seria a impossibilidade no sistema amostraequipamento, optou-se por realizar um teste com um material puramente expansivo, o qual foi a bentonita. $\mathrm{O}$ corpo de prova de bentonita foi compactado após a secagem do material ao ar, diretamente no cilindro da célula edométrica e submetido ao ensaio de expansão por transferência de vapor. O resultado foi positivo, o que permitiu constatar que o equipamento desenvolvido apresentava condições satisfatórias para conduzir esse tipo de ensaio. Dessa forma, o desafio passou a ser a análise das condições das amostras de material da Formação Corumbataí.

$\mathrm{Na}$ literatura, diversos autores propuseram utilizar misturas de materiais argilosos e arenosos compactados para aplicação em barreiras de resíduo radioativo em diferentes densidades secas $\left(\rho_{\mathrm{d}}\right)$ e verificar o comportamento expansivo dos mesmos. Delage et al. (1998) estudaram um 
tipo de argila expansiva compactada com $\rho_{\mathrm{d}}$ de $1,85 \mathrm{~g} / \mathrm{cm}^{3}$ e umidade de $13 \%$. Komine (2004) estudou o comportamento expansivo de várias bentonitas com características distintas compactadas com $\rho_{\mathrm{d}}$ variando entre 1,37 e $1,90 \mathrm{~g} / \mathrm{cm}^{3}$.

Tang et al. (2011) analisaram o comportamento de um argilito compactado para substituir a bentonita comercial na selagem de resíduos radioativos. Esse material foi compactado com $\rho_{\mathrm{d}}$ de $2,0 \mathrm{~g} / \mathrm{cm}^{3}$ e umidade variando entre $3 \%$ e $9 \%$. Lee at al. (2012) analisaram a expansão da bentonita seca compactada com densidades secas de 1,5, 1,6 e 1,7 g/cm $\mathrm{cm}^{3}$ em contato com solução de $\mathrm{NaCl}$ em diferentes concentrações. Os autores mediram a expansão axial e radial do material. Cui et al. (2012) estudaram misturas de areia e bentonita com porcentagens entre 0 e 50\%. Foram analisadas as expansões de corpos de prova compactados de forma estática com $\rho_{\mathrm{d}}$ entre 1,5 e $2,01 \mathrm{~g} / \mathrm{cm}^{3}$, e também compactados de forma dinâmica com $\rho_{\mathrm{d}}$ entre $1,22 \mathrm{e}$ $1,5 \mathrm{~g} / \mathrm{cm}^{3}$.

Decidiu-se, então, testar a amostra argilosa da Formação Corumbataí compactada na condição seca ao ar, uma vez que, na condição compactada na umidade ótima e seca ao ar não havia apresentado resultados positivos de expansão. As densidades secas de compactação variaram entre 1,39 e 1,66 g/ $\mathrm{cm}^{3}$. Como esperado, o resultado nesta condição foi positivo, e assim, foi realizada uma série de ensaios desta amostra com bentonita em diferentes proporções de misturas. Testou-se, também, o comportamento da bentonita misturada com solo arenoso.

\subsubsection{Mistura de Material Argiloso da Formação Corumbataí com Bentonita}

Foram utilizadas as mesmas proporções de mistura solo-bentonita dos ensaios de expansão inundada, a fim de comparar o comportamento expansivo entre as duas técnicas. Os resultados dos ensaios de expansão por transferência de vapor mostrados na Figura 4.15 apresentam certa consistência nas máximas pressões obtidas com relação às proporções de bentonita, ou seja, quanto maior a porcentagem, maior é a pressão de expansão. Com exceção das misturas de $10 \%$ e 5\% de bentonita, que apresentaram valor inferior de expansão em comparação à amostra composta somente de material argiloso.

Explica-se este comportamento devido à presença do argilomineral montmorilonítico influenciar na expansão dos materiais argilosos a partir de uma certa quantidade. Portanto, neste caso as porcentagens de $5 \%$ e $10 \%$ de bentonita não foram suficientes para alimentar a expansão, pelo contrário, reduziu o valor da pressão de expansão, uma vez que foi influenciada pelos índices físicos iniciais das amostras, e pelo tamanho de poros. 
$\sqrt{ }$ Expansão por Transferência de Vapor versus Expansão Inundada

A pressão de expansão no material argiloso compactado sem bentonita mostrou-se bem mais expressiva no ensaio inundado com $\mathrm{P}_{\text {máx }}$ de $441,15 \mathrm{kPa}$, enquanto que na transferência de vapor foi de 109,65 kPa, ou seja, cerca de quatro vezes maior. Esse valor baixo de expansão por transferência de vapor pode ser reflexo do processo lento de umedecimento durante o ensaio. Outro fator que pode justificar a baixa expansão seria a ausência de argilomineral do grupo das esmectitas.

Na literatura alguns autores como Oliveira (1992), comentam que a hidratação do material pode levar à formação de filmes de água entre as partículas, cujas superfícies específicas se ampliam pela redução do tamanho. A formação desses filmes de hidratação pode estar relacionada com a maior superfície específica, com o menor tamanho das partículas, e com a forma mais irregular das mesmas. No caso desta pesquisa com a amostra compactada seca, a forma de umedecimento por transferência de vapor foi lenta, tal qual insuficiente para ser capaz de hidratar satisfatoriamente e formar esses filmes ao redor das partículas finas.

Como visto na caracterização mineralógica, o material argiloso da Formação Corumbataí é composto basicamente, de argilomineral caulinítico. Segundo Tessier et al. (1990), o umedecimento rápido de materiais cauliníticos provoca o surgimento de fraturas devido à pressões de bolhas de ar aprisionadas, que podem escapar se o umedecimento for lento. Portanto, a reorganização dos microporos após o umedecimento pode estar associada ao tipo de composição mineralógica.

Alferes (2011) ressalta que solos argilosos compactados poucos expansivos utilizados na construção de aterros podem sofrer variação de volume. A magnitude dessas deformações depende das condições de compactação, tensão aplicada, assim como da sucção imposta antes do umedecimento, como é o caso da expansão por inundação.

Para as outras condições ensaiadas, os valores de pressão de expansão ficaram muito próximos aos da expansão inundada, apresentando apenas uma pequena redução. De maneira geral, não houve discrepância entre as misturas na inundação comparada às misturas ensaiadas com a transferência de vapor, o que caracteriza um comportamento expansivo semelhante em face às duas técnicas. Essa afirmação vale, apenas, quando o material apresenta teores mais elevados de argilominerais expansivos. 
A Figura 5.46 mostra as pressões máximas de expansão nas diferentes porcentagens de bentonita para as duas técnicas de ensaio. Nota-se que há uma convergência das linhas de tendência entre as duas técnicas na porcentagem de 70\%, e após esse ponto a expansão da bentonita pura apresenta-se maior na transferência de vapor. A diferença inicial entre as pressões de expansão é função do comportamento da amostra pura de solo argiloso da Formação Corumbataí nos dois modos de umedecimento.

Os resultados apresentados na Figura 5.46 corroboram a hipótese de que a técnica da transferência de vapor é significativa e válida para a previsão do comportamento expansivo somente de amostras com teores altos de argilominerais expansivos ( $\geq 70 \%)$. Nos demais casos, este método subestima as pressões máximas de expansão.

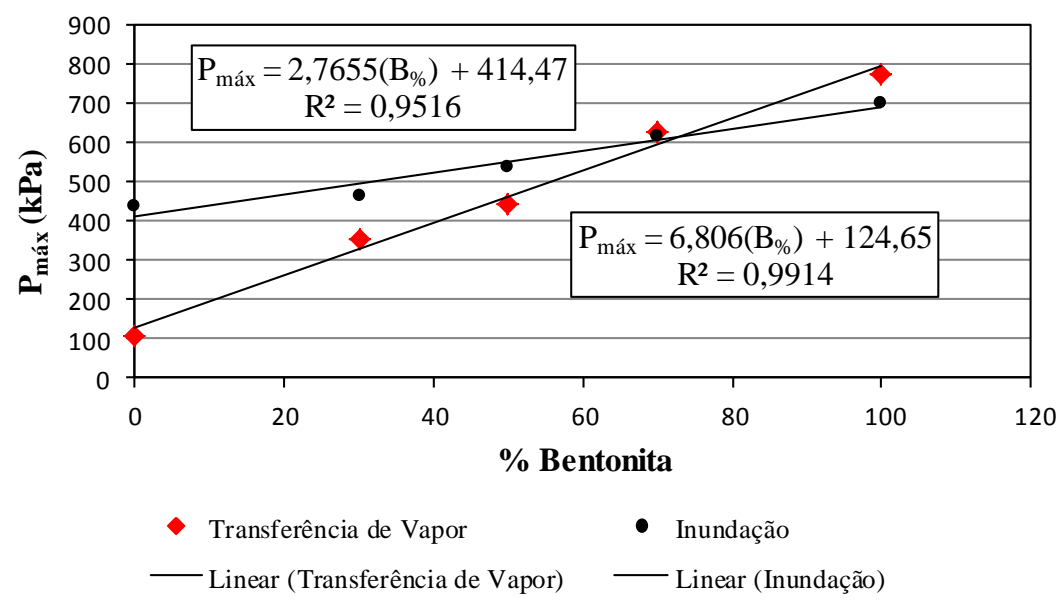

Figura 5.46 - Pressões máximas de expansão versus Porcentagem de Bentonita para ensaios inundados e ensaios por transferência de vapor nas misturas argilosas.

Os índices físicos iniciais das amostras também apresentam similaridade. O que diferiu de forma significativa foi o nível de sucção inicial, o que pode explicar, também, uma pequena redução nas pressões máximas de expansão.

\subsubsection{Mistura de Material Arenoso da Formação Botucatu com Bentonita}

Foram testadas, também, amostras arenosas misturadas com bentonita em algumas proporções semelhantes às misturas arenosas dos ensaios inundados. Como era de se esperar, os resultados desses ensaios apresentados na Figura 4.16 mostraram consistência nas pressões máximas de expansão em relação ao aumento da porcentagem de bentonita. 
$\sqrt{ }$ Expansão por Transferência de Vapor versus Expansão Inundada

A Figura 5.47 mostra as pressões máximas de expansão nas diferentes porcentagens de bentonita para as duas técnicas de ensaio. Observa-se que as linhas de tendência convergem em $50 \%$ de bentonita, e após esse ponto as pressões maiores são reveladas para a técnica da transferência de vapor, assim como ocorreu nas misturas argilosas.

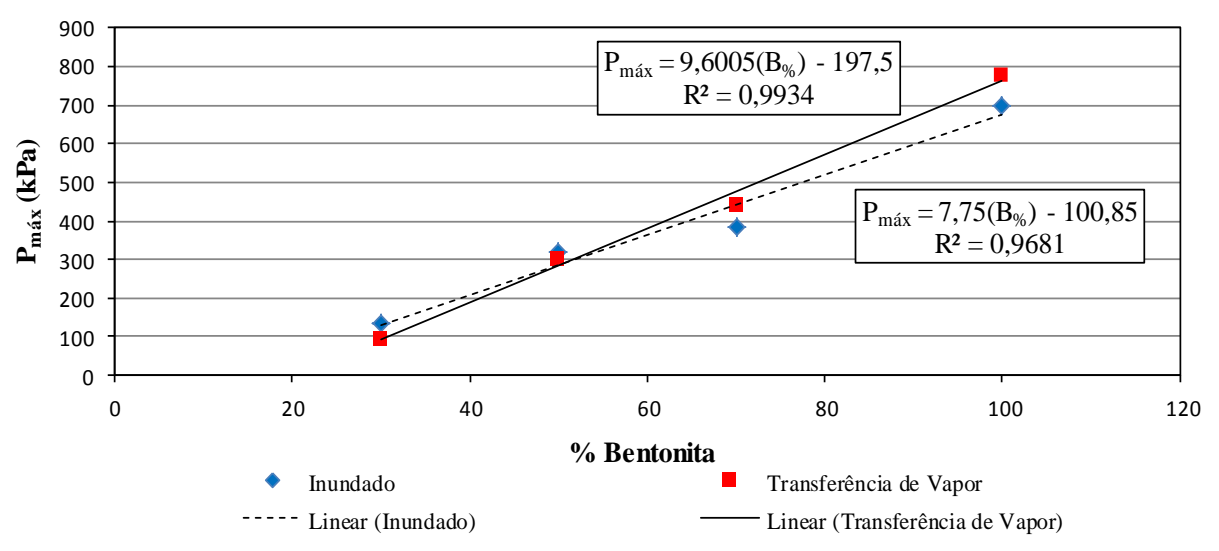

Figura 5.47 - Pressões máximas de expansão versus Porcentagem de Bentonita para ensaios inundados e ensaios por transferência de vapor nas misturas arenosas.

De um modo geral, as condições iniciais das amostras no que se refere aos índices físicos e sucção não diferiram entre as duas técnicas, corroborando os resultados semelhantes. Dessa forma, pode-se afirmar que a técnica utilizada para analisar a expansão não influenciou nos resultados para misturas de solo arenoso com bentonita pura. Estes resultados vêm confirmar que na situação quando o argilomineral presente é só do tipo expansivo (montmorilonita), a expansão inundada e por transferência de vapor conduzem a valores muito próximos de pressão de expansão, independente da porcentagem de argilomineral na mistura.

\subsubsection{Comparação entre Pressões Máximas de Expansão nas Misturas}

Como mostra a Figura 5.48, as pressões máximas de expansão foram maiores nas misturas argilosas com bentonita. Esse resultado já era esperado, ainda que o material argiloso não apresente argilomineral expansivo, a caulinita presente em sua composição pode ter manifestado influência na expansão. Vale ressaltar que esse material apresenta elevada capacidade de absorção de água, que está intimamente ligada às condições de sucção iniciais impostas, o que implica em uma considerável variação volumétrica.

O aumento na porcentagem de bentonita conduz a aproximação das retas para valores próximos de pressão máxima de expansão. Essa tendência é reflexo da expansão da bentonita, 
que controla, a partir de um certo teor, o processo de expansão, minimizando a influência do material misturado (argila). A diferença inicial entre as pressões de expansão é de $200 \mathrm{kPa}$. Após $50 \%$ de acréscimo de bentonita essa diferença diminui para $120 \mathrm{kPa}$, e assim sucessivamente até que as linhas de tendência se cruzam.

A partir da equação obtida para a reta da mistura argilosa é possível estimar a pressão máxima de expansão em um intervalo de 0 a $100 \%$ de bentonita a ser adicionada em materiais com características mineralógicas semelhantes. O mesmo pode-se aplicar o ajuste aos dados da mistura arenosa, em um intervalo de $30 \%$ a $100 \%$.

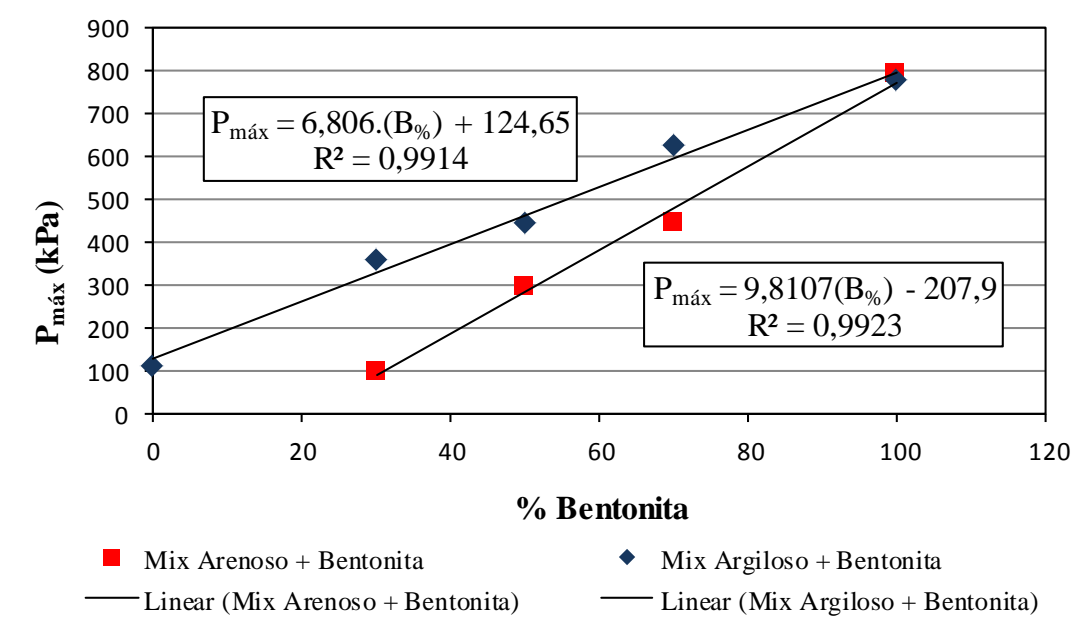

Figura 5.48 - Curva de pressão de expansão versus porcentagem de bentonita para misturas argilosas e arenosas nos ensaios com a transferência de vapor.

Pode-se inferir, então, que o material argiloso teve sua parcela de contribuição na expansão, como visto na Figura 5.48. Enquanto que, a mistura de material arenoso revela o desempenho de um material artificial composto de argilomineral expansivo que permite apenas caracterizar o comportamento das porcentagens de bentonita, sem levar em consideração o desempenho do material misturado (areia).

\subsubsection{Comparação entre Pressão Máxima de Expansão e Densidade Seca Inicial}

A pressão de expansão de materiais compactados em diferentes densidades foi estudada por diversos autores, como Gray et al. (1985), Komine e Ogata (2004), Çimer et al. (2012) e Lee et al. (2012). Esses autores afirmam que o efeito da densidade seca inicial de compactação afeta na máxima pressão de expansão que é aumentada para elevados valores de $\rho_{\mathrm{d}}$. Este fato ocorre principalmente quando se trabalha com materiais altamente sensíveis à variação de densidade, como é o caso da bentonita. 
Leet et al. (2012) comenta, ainda, que o aumento acentuado na pressão de expansão de bentonitas não se dá apenas pela densidade elevada, mas também, pela natureza anisotrópica do material compactado. A bentonita compactada em densidades secas baixas constitui em arranjos agregados de partículas dispostas aleatoriamente, enquanto que a compactação realizada em densidades acima de $1,6 \mathrm{~g} / \mathrm{cm}^{3}$ elimina os vazios interpartículas formando um arranjo mais uniforme.

Nesta pesquisa, a densidade seca das amostras de mistura de material argiloso com bentonita variou entre 1,40 e 1,56 g/ $\mathrm{cm}^{3}$ nos ensaios inundados, e 1,39 e $1,52 \mathrm{~g} / \mathrm{cm}^{3}$ nos ensaios com a transferência de vapor (Tabela 5.15). Esse intervalo não ultrapassou a $1,6 \mathrm{~g} / \mathrm{cm}^{3}$ como citado por Lee et al (2012) para maior desenvolvimento da expansão da bentonita.

Tabela 5.15 - Valores de índices físicos e pressões máximas de expansão para as amostras de material argiloso misturadas com bentonita.

\begin{tabular}{|c|c|c|c|c|c|c|}
\hline \multirow{2}{*}{ \% Bentonita } & \multicolumn{3}{|c|}{ Inundação } & \multicolumn{3}{c|}{ Transferência de Vapor } \\
\cline { 2 - 7 } & $\mathrm{P}_{\text {máx }}(\mathrm{kPa})$ & $\rho_{\mathrm{d}}\left(\mathrm{g} / \mathrm{cm}^{3}\right)$ & $\mathrm{W}_{\text {inicial }}(\%)$ & $\mathrm{P}_{\text {máx }}(\mathrm{kPa})$ & $\rho_{\mathrm{d}}\left(\mathrm{g} / \mathrm{cm}^{3}\right)$ & $\mathrm{W}_{\text {inicial }}(\%)$ \\
\hline 30 & 462,65 & 1,53 & 5,13 & 365,15 & 1,54 & 6,83 \\
\hline 50 & 541,15 & 1,52 & 7,23 & 441,65 & 1,53 & 8,64 \\
\hline 70 & 619,65 & 1,53 & 9,1 & 627,15 & 1,53 & 8,9 \\
\hline 100 & 699,15 & 1,39 & 7,29 & 777,15 & 1,52 & 12,83 \\
\hline
\end{tabular}

A Figura 5.49 mostra a relação entre a pressão máxima de expansão e as densidades secas iniciais para algumas porcentagens de mistura de material argiloso com bentonita, não levando em consideração o resultado da amostra compactada seca sem bentonita. 


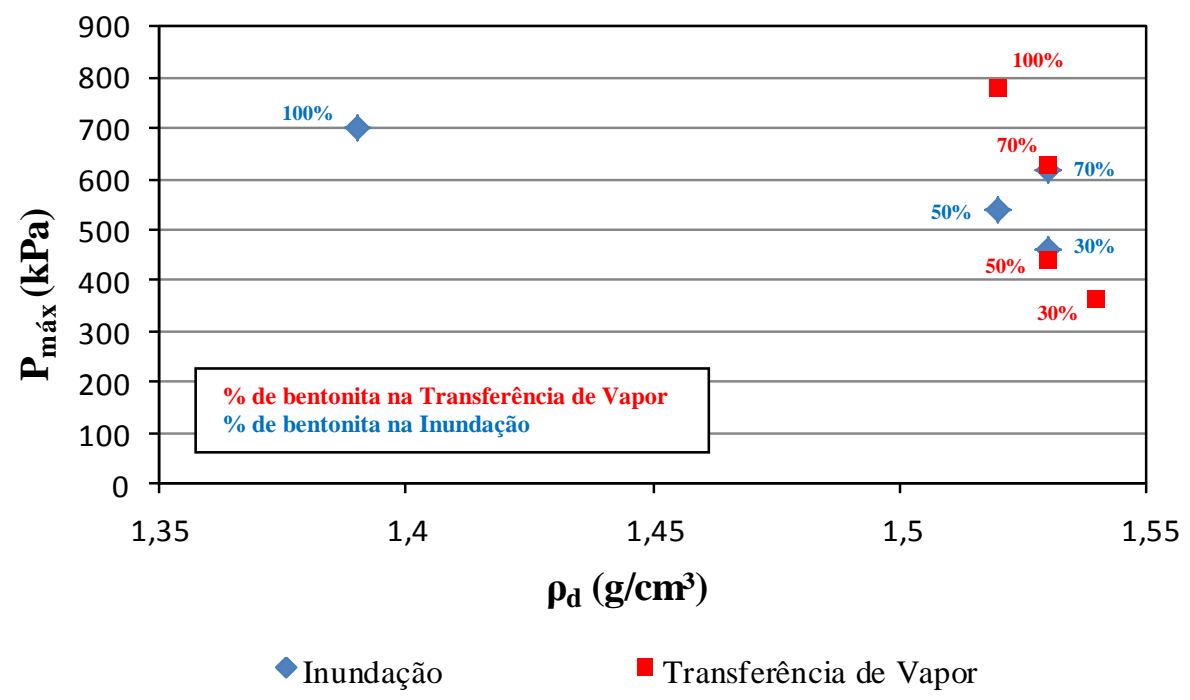

Figura 5.49 - Pressão máxima de expansão e densidade seca inicial entre as misturas argilosas com bentonita.

Com exceção da amostra de bentonita pura submetida ao ensaio de expansão inundada que apresentou $\rho_{\mathrm{d}}$ de $1,39 \mathrm{~g} / \mathrm{cm}^{3}$, todos os demais ensaios situaram-se em valores próximos a 1,53. Em consequência, não se pode caracterizar a influência do $\rho_{\mathrm{d}}$ na expansão como relatado pelos autores citados. No entanto, ficou evidente, novamente, a influência da porcentagem de bentonita, uma vez em que, amostras com $\rho_{\mathrm{d}}$ 's próximos apresentaram pressões de expansão crescente com o aumento do teor de bentonita (Tabela 5.15). Isso se confirma no caso da bentonita pura, que mesmo com um valor bem menor de $\rho_{\mathrm{d}}$ teve expansão mais elevada.

Nas misturas de solo arenoso com bentonita, as densidades variaram entre 1,39 e 1,76 g/cm ${ }^{3}$ para os ensaios inundados, e 1,52 e $1,76 \mathrm{~g} / \mathrm{cm}^{3}$ para os ensaios com a transferência de vapor (Tabela 5.16).

Tabela 5.16 - Valores de índices físicos e pressões máximas de expansão para as amostras de material arenoso misturadas com bentonita.

\begin{tabular}{|c|c|c|c|c|c|c|}
\hline \multirow{2}{*}{ \% Bentonita } & \multicolumn{3}{|c|}{ Inundação } & \multicolumn{3}{c|}{ Transferência de Vapor } \\
\cline { 2 - 7 } & $\mathrm{P}_{\text {máx }}(\mathrm{kPa})$ & $\rho_{\mathrm{d}}\left(\mathrm{g} / \mathrm{cm}^{3}\right)$ & $\mathrm{W}_{\text {inicial }}(\%)$ & $\mathrm{P}_{\text {máx }}(\mathrm{kPa})$ & $\rho_{\mathrm{d}}\left(\mathrm{g} / \mathrm{cm}^{3}\right)$ & $\mathrm{W}_{\text {inicial }}(\%)$ \\
\hline 30 & 134,15 & 1,76 & 2,82 & 93,15 & 1,73 & 3,72 \\
\hline 50 & 319,15 & 1,67 & 4,61 & 299,15 & 1,65 & 6,25 \\
\hline 70 & 381,65 & 1,51 & 6,39 & 440,65 & 1,75 & 8,48 \\
\hline 100 & 699,15 & 1,39 & 12,83 & 777,15 & 1,52 & 12,82 \\
\hline
\end{tabular}

Como se pode verificar na Figura 5.50, algumas misturas apresentaram densidades secas iniciais acima de $1,6 \mathrm{~g} / \mathrm{cm}^{3}$. No entanto, isto se deve a porcentagem de bentonita ser igual ou 
inferior a 50\% em relação à fração areia. Novamente, ressalta-se a importância evidente da porcentagem de bentonita presente na mistura, pois as amostras inundadas exibiram maiores pressões de expansão para teores crescentes de bentonita, mesmo com a diminuição do $\rho_{\mathrm{d}}$. Portanto, o aumento da expansão com o aumento do $\rho_{\mathrm{d}}$ só se manifesta nitidamente quando o tipo e porcentagem do argilomineral se mantiverem constantes.

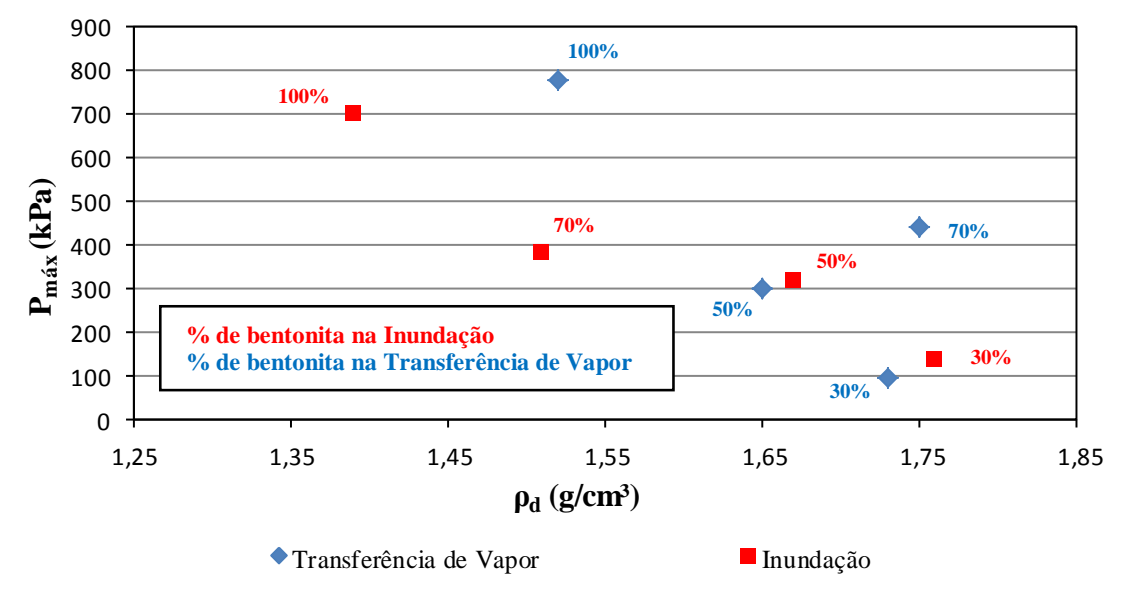

Figura 5.50 - Pressão máxima de expansão e densidade seca inicial entre as misturas arenosas com bentonita.

Em contra partida, Wayllace (2008) comenta que a microestrutura de argilas expansivas pode ser dividida entre intra agregada e inter agregada, em que a intra compreende a microporosidade e a inter a macroporosidade. Assim, a inter agregada é altamente afetada pela variação das densidades secas; e a intra, na qual correspondem os espaços vazios intrapartículas é, relativamente, não afetada pelo processo de compactação da amostra.

Portanto, nos ensaios em que a bentonita foi ensaiada com densidades mais baixas exibindo pressões de expansão mais alta, associa-se que essa densidade teve pouco efeito sobre a agregação intraporto, e que a compactação atuou, apenas, removendo as maiores agregações entre os poros.

\subsubsection{Comparação entre Pressão Máxima de Expansão e Umidade Inicial}

Entre os índices físicos que mais influenciam na pressão de expansão, pode-se destacar o teor de umidade inicial. Amostras mais secas tendem a apresentar pressões de expansão mais elevadas. Porém, nesta pesquisa não foi possível fazer essa inferência visto que, as pressões de expansão aumentaram com o aumento da umidade, mas esse aumento de umidade é função do aumento na porcentagem de bentonita na mistura. Ou seja, quanto maior a quantidade de 
bentonita na mistura, maior será o teor de umidade, pois este material apresenta alta sensibilidade e capacidade de absorção de água.

A constatação de aumento na pressão de expansão para baixos teores de umidade inicial só poderia ser feita se fossem realizados ensaios com a mesma mistura em diferentes teores de umidade. Apesar disto, apresenta-se na Figura 5.51 uma comparação da evolução da pressão de expansão para diferentes teores de umidade, sem analisar o fenômeno físico relacionado ao aumento de umidade das misturas de solo argiloso com bentonita. Essa comparação é feita somente para mostrar que o comportamento expansivo foi crescente, não podendo inferir uma correlação entre esses parâmetros visto que estão sob diferentes condições de mistura.

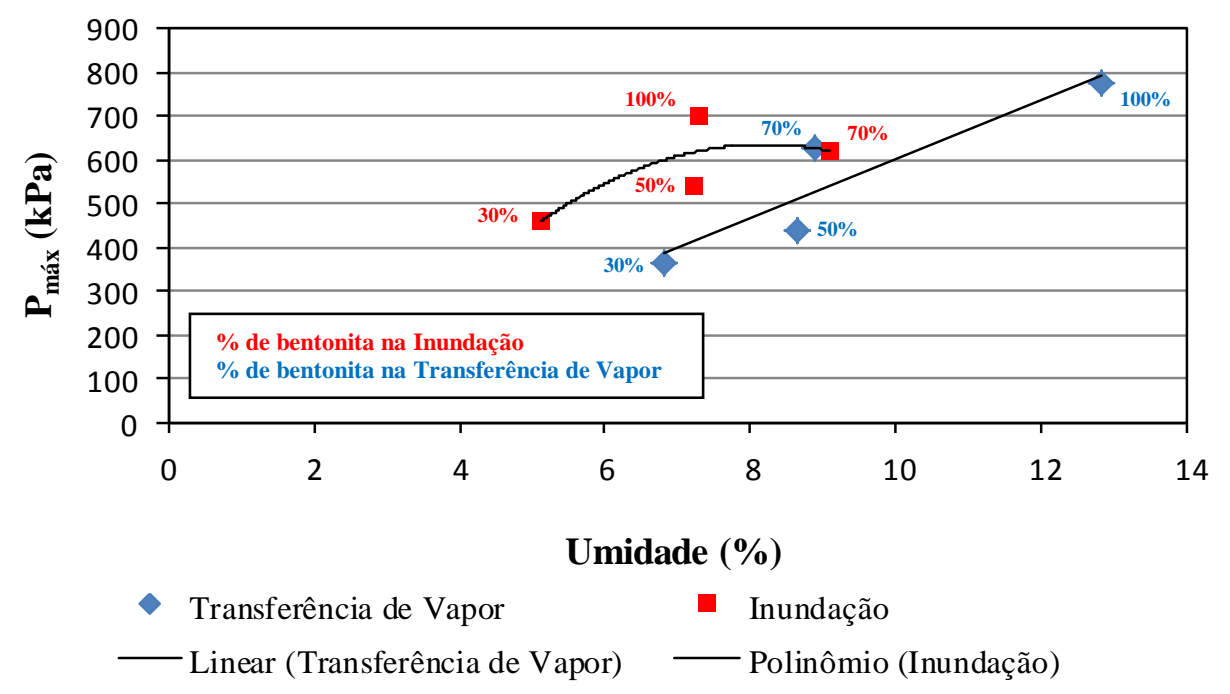

Figura 5.51 - Pressão máxima de expansão e umidade inicial entre as misturas argilosas com bentonita.

A Figura 5.52 mostra a relação entre a pressão máxima de expansão e a umidade inicial das misturas arenosas com bentonita. Para essas misturas, o comportamento crescente da pressão de expansão ficou evidente, para as duas condições de ensaio. Novamente observa-se que o efeito do aumento do teor de bentonita em produzir pressões de expansão mais elevada suplantou um possível efeito de redução da expansão advindo do aumento de teor de umidade inicial.

Nota-se que a inundação mantém pressões de expansão elevadas para as misturas de $30 \%$, $50 \%$ e $70 \%$. Já para a expansão da bentonita com o mesmo teor de umidade, a pressão de expansão mostrou-se maior no ensaio com a transferência de vapor. 


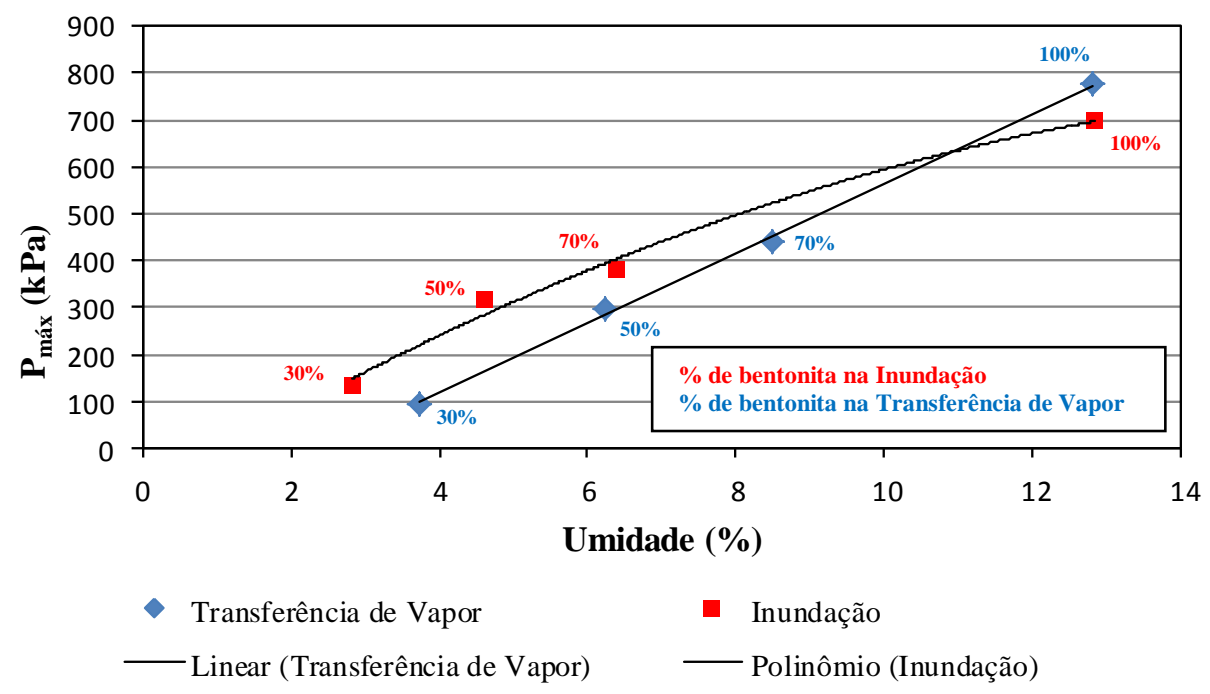

Figura 5.52 - Pressão máxima de expansão e umidade inicial entre as misturas arenosas com bentonita.

\subsubsection{Sucção Final dos Ensaios com a Transferência de Vapor}

A sucção final dos ensaios conduzidos com a transferência de vapor foi determinada por meio de papéis de filtro instalados no reservatório de solução salina. Os valores de sucção foram calculados a partir da pesagem desses papéis ao término de cada ensaio de expansão com a transferência de vapor, a fim de confirmar se o ambiente interno estava sob o nível de sucção imposta a partir da solução salina de $\mathrm{NaCl}$. A Tabela 5.17 apresenta os valores de sucção final para cada mistura de solo argiloso e solo arenoso. Verificou-se que no ambiente do reservatório os níveis de sucção estavam consistentes com o valor de sucção desejado de $5.000 \mathrm{kPa}$.

Tabela 5.17 - Sucção final dos ensaios de transferência de vapor medidos com o papel filtro.

\begin{tabular}{|c|c|c|}
\hline Ensaio & $\mathbf{w}_{\text {papel }}(\boldsymbol{\%})$ & Sucção $(\mathbf{k P a})$ \\
\hline Bentonita & 18,2375 & 5077 \\
\hline Argiloso + 70\% Bent. & 18,3126 & 5023 \\
\hline Argiloso + 50\% Bent. & 18,2174 & 5092 \\
\hline Argiloso + 30\% Bent. & 18,2261 & 5086 \\
\hline Argiloso + 10\% Bent. & 18,3150 & 5021 \\
\hline Argiloso + 5\% Bent. & 18,2292 & 5083 \\
\hline Seca/ Seca ao Ar & 18,3620 & 4988 \\
\hline Arenoso + 70\% Bent. & 18,2716 & 5052 \\
\hline Arenoso + 50\% Bent. & 18,2635 & 5058 \\
\hline Arenoso + 30\% Bent. & 18,2025 & 5103 \\
\hline
\end{tabular}




\subsection{Expansão Inundada após Transferência de Vapor}

Após o término dos ensaios conduzidos com a técnica da transferência de vapor por imposição de umidade relativa, as amostras foram submetidas à inundação a fim de verificar a evolução da pressão de expansão. Portanto, retirou-se o sistema de circulação de vapor e o reservatório de solução salina, e completou-se a célula edométrica com água destilada/deionizada até a altura da placa crivada.

Os resultados dessa segunda fase de expansão estão mostrados na Figura 5.53 para as misturas de solo argiloso com bentonita, e as pressões de expansão final estão apresentadas na Tabela 5.18. Nota-se que a amostra de bentonita pura e a amostra da mistura com $70 \%$ de bentonita reduziram a pressão de expansão com a inundação após a transferência de vapor, os valores finais ficaram um pouco abaixo da pressão máxima de expansão obtida nos ensaios realizados somente com inundação. Ou seja, apenas essas duas condições ensaiadas já haviam mobilizado toda a expansão na primeira fase de ensaio.

Nos demais casos, houve aumento da pressão de expansão com a inundação após o ensaio com sucção controlada, com o resultado final sendo em alguns casos menor e outros maiores que a pressão máxima de expansão dos ensaios inundados diretos (Tabela 5.18).

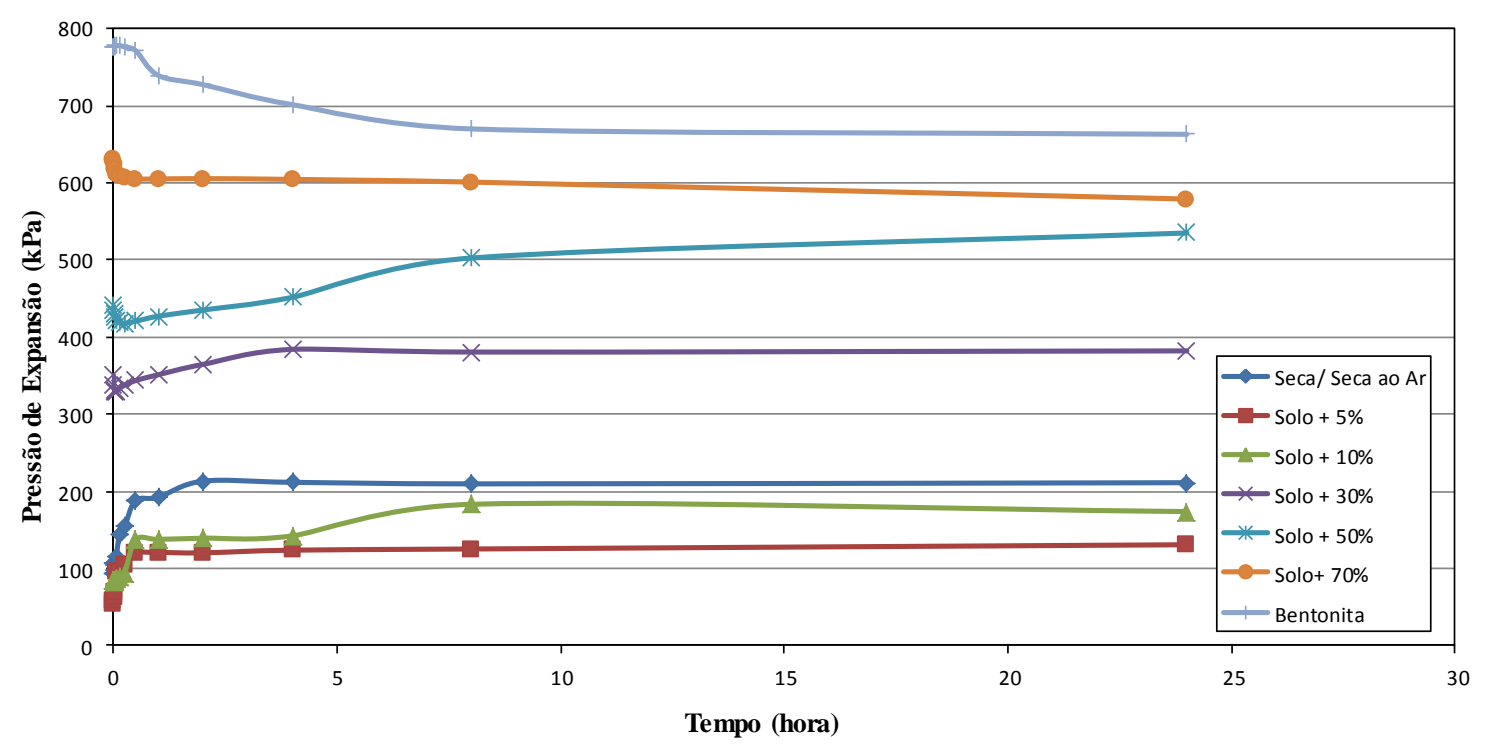

Figura 5.53 - Expansão inundada após transferência de vapor para as misturas de solo argiloso com bentonita. 
Tabela 5.18 - Pressões de expansão final após transferência de vapor, e pressões finais do ensaio inundado direto para as misturas de material argiloso com bentonita.

\begin{tabular}{|c|c|c|}
\hline Ensaio & $\mathbf{P}_{\text {final }}(\mathbf{k P a})$ & $\mathbf{P}_{\text {inundado direto }}(\mathbf{k P a})$ \\
\hline Bentonita & 663,15 & 699,15 \\
\hline Argiloso + 70\% Bent. & 576,15 & 619,65 \\
\hline Argiloso + 50\% Bent. & 580,15 & 541,15 \\
\hline Argiloso + 30\% Bent. & 382,15 & 462,65 \\
\hline Argiloso + 10\% Bent. & 173,65 & 283,65 \\
\hline Argiloso + 5\% Bent. & 130,65 & 87,65 \\
\hline Seca/ Seca ao Ar & 211,15 & 441,15 \\
\hline
\end{tabular}

Para as misturas de material arenoso com bentonita, a segunda fase de ensaio correspondente à inundação é apresentada na Figura 5.54, e os respectivos valores finais de expansão são mostrados na Tabela 5.19. Para essas condições estudadas, todas as misturas apresentaram aumento de expansão na inundação após a transferência de vapor, com exceção da mistura com $50 \%$ de bentonita. Vale destacar o comportamento da mistura de $70 \%$ de bentonita com material arenoso, que apresentou aumento expressivo na expansão final, sendo inclusive maior que o valor de pressão máxima de expansão obtida no ensaio inundado direto (Tabela 5.19). Para a amostra com 50\% de bentonita os valores finais ficaram muito próximos, enquanto que para a amostra com $30 \%$ a expansão após a sucção também foi maior que a expansão inundada direta (Tabela 5.19).

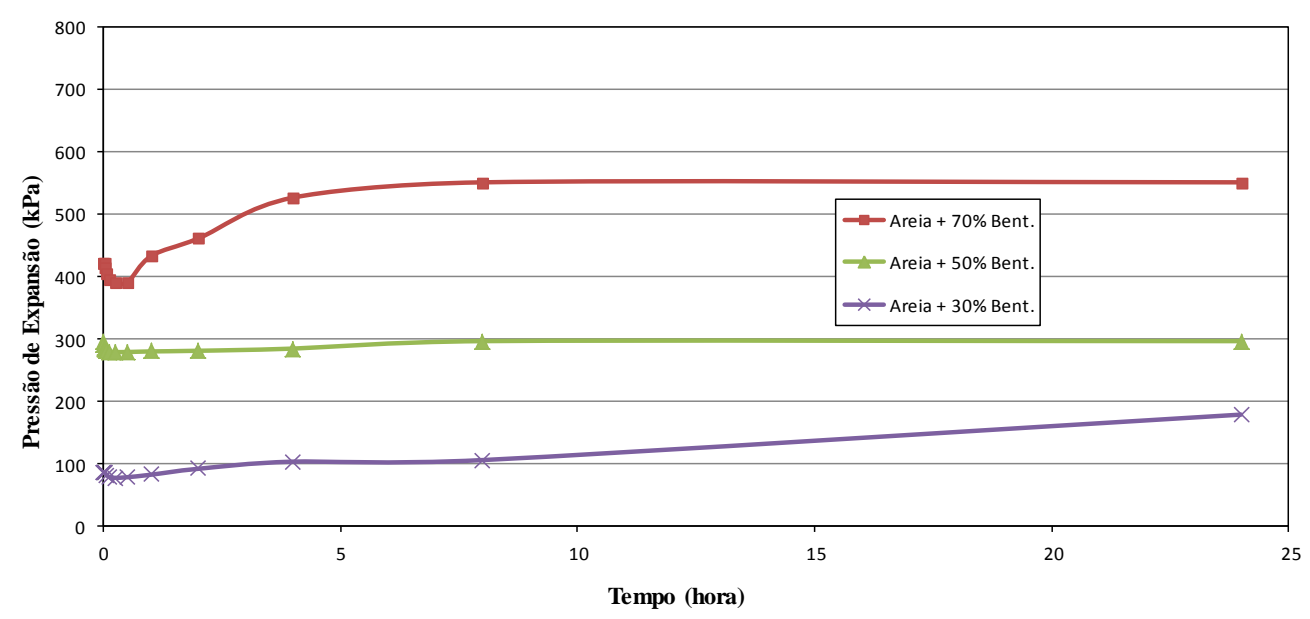

Figura 5.54 - Expansão inundada após transferência de vapor para as misturas de material arenoso com bentonita. 
Tabela 5.19 - Pressões de expansão final após transferência de vapor, e pressões finais do ensaio inundado direto para as misturas de material arenoso com bentonita.

\begin{tabular}{|c|c|c|}
\hline Ensaio & $\mathbf{P}_{\text {final }}(\mathbf{k P a})$ & $\mathbf{P}_{\text {inundado direto }}(\mathbf{k P a})$ \\
\hline Arenoso + 70\% Bent. & 551,15 & 381,65 \\
\hline Arenoso + 50\% Bent. & 296,15 & 319,15 \\
\hline Arenoso + 30\% Bent. & 178,15 & 134,15 \\
\hline
\end{tabular}

Observa-se que a porcentagem de $70 \%$ de bentonita misturada em diferentes materiais, sendo este argiloso ou arenoso, apresenta comportamento distinto. Visto que, a sua expansão é mobilizada na transferência de vapor ao ser misturado com solo argiloso, enquanto que, ao ser misturado com solo arenoso essa expansão ainda se revela expressiva em uma inundação na segunda fase. Ou seja, o esqueleto na qual a bentonita está sob arranjo tem influência na mobilização da expansão em diferentes técnicas ensaio. 


\section{CONCLUSÕES}

\subsection{Características dos Materiais Analisados}

Os ensaios de caracterização mineralógica permitiram uma identificação bem definida da mineralogia dos materiais estudados. Constatou-se a ausência de argilomineral do grupo das esmectitas nas amostras argilosas da Formação Corumbataí. Porém, foi identificada a presença de caulinita e, também, de ilita. O material arenoso da Formação Botucatu caracterizado por Loch (2013) apresentou, basicamente, quartzo e caulinita na sua composição mineralógica. A bentonita utilizada nos ensaios de expansão exibiu a presença abundante do argilomineral montmorilonita, indicando alto potencial à expansão.

Quanto às características de retenção de água, o material argiloso da Formação Corumbataí apresentou trechos bem definidos de dessaturação, o que permitiu determinar o intervalo de sucção a ser imposto nas amostras antes dos ensaios de expansão inundada. Foram adotados intervalos com valores entre 40.000 e $5.000 \mathrm{kPa}$ determinados pela curva de retenção pelo método do papel filtro e funil de placa porosa. As curvas de retenção pelo método do dessecador a vácuo confirmaram os intervalos de sucção adotados pelas outras metodologias, permitindo controlar as umidades das amostras correspondentes a cada intervalo escolhido antes dos ensaios de expansão.

\subsection{Comportamento Expansivo}

\subsubsection{Expansão Inundada}

De um modo geral, nos ensaios com material argiloso da Formação Corumbataí, as amostras indeformadas apresentaram maiores pressões de expansão em relação às amostras compactadas. Pode-se concluir que os índices físicos iniciais das amostras influenciaram de forma significativa nesse comportamento, destacando-se, principalmente, o $\rho_{d}$ e o $S_{r}$. Observou-se, ainda, que as amostras quando compactadas na umidade ótima e estabilizadas no dessecador a vácuo, revelam um comportamento diferente quando compactadas secas na forma de pó em densidades mais elevadas.

Os ensaios de expansão inundada nas amostras compactadas na umidade ótima, e posteriormente estabilizadas no dessecador ou seca ao ar, revelaram pressões de expansão 
crescentes com o aumento de sucção, como já era esperado. Porém, esses valores foram menores que as pressões de expansão das amostras indeformadas. Esse comportamento das amostras compactadas pode ser justificado devido à compactação ter sido na umidade ótima. Neste caso, essas pressões poderiam ser maiores em relação às pressões de expansão das indeformadas se o material fosse compactado seco (na forma de pó), e em seguida colocado no dessecador até estabilização na sucção desejada.

Desse modo, pode-se inferir que amostras compactadas menos densas sofrem variação de volume de forma interna, ou seja, a expansão nos vazios interpartículas é absorvida internamente pelos poros de maior tamanho, sem reproduzir o efeito em uma variação de volume total da amostra. Já as compactadas em maiores densidades, são mais eficientes, e conseguem responder com pressões de expansão expressivas, pois as variações de volume que ocorrem nos vazios interpartículas são menos acomodadas pelos poros internos de maior tamanho, e assim, há um contato maior entre o intraporo e o interporo, revelando a variação de volume.

Os ensaios conduzidos com misturas de material argiloso e material arenoso com bentonita mostraram maiores valores de expansão para as misturas argilosas. Acredita-se que esse comportamento tenha sido influenciado não somente pelas diferentes porcentagens de bentonita adicionada nas misturas, mas também, pelas condições iniciais das amostras, em termos de índices físicos e nível inicial de sucção.

\section{$\sqrt{ }$ Distribuição dos Poros}

Na porosimetria por intrusão de mercúrio realizada nas amostras da Formação Corumbataí, após a expansão, notou-se que os microporos continuaram na mesma faixa de diâmetro, com variação, apenas, na frequência. No entanto, os macroporos sofreram variação de diâmetro e frequência após a expansão. Essas amostras exibiram maior porcentagem de macroporos antes e após a expansão, e sofreram uma redução nos mesos e microporos após a expansão inundada, exceto a amostra estabilizada na sucção de $40.000 \mathrm{kPa}$.

As amostras compactadas da Formação Corumbataí apresentaram distribuição de poros de forma bimodal em todas as condições analisadas, antes e após a expansão. Em algumas situações observaram-se três intervalos de poros, ou seja, foi revelado um tamanho de poro intermediário. As amostras não apresentaram evolução após a expansão, com exceção da 
condição estabilizada na sucção de $40.000 \mathrm{kPa}$, a qual o macroporo foi dividido em dois intervalos de poros.

A porosimetria das misturas foi realizada, apenas, antes dos ensaios de expansão. As misturas argilosas exibiram distribuição de poros bimodal, enquanto que as misturas arenosas apresentaram-se unimodais. Verificou-se que as misturas argilosas com maior porcentagem de bentonita exibiram maior frequência de macroporos, e frequência de microporos indefinida. Neste caso, pode-se dizer que a adição bentonita teve efeito maior nos macroporos dessas misturas.

\section{$\sqrt{ }$ Microscopia Eletrônica de Varredura}

A microscopia eletrônica de varredura também foi realizada nas amostras antes e após os ensaios de expansão a fim de analisar de forma qualitativa o comportamento estrutural e textural dos materiais. O material indeformado da Formação Corumbataí não exibiu minerais expansivos do grupo das esmectitas (montmorilonita), revelando, apenas caulinita e ilita em sua composição mineralógica. Em relação ao comportamento estrutural e textural, ficou evidente a presença de vazios de diferentes dimensões nas amostras, e também, a presença de trincas e fissuras após a expansão.

Nas amostras compactadas da Formação Corumbataí foram notou-se, que o material apresentou um aspecto desagregado, com estrutura bastante modificada devido ao processo de compactação, o que dificultou a obtenção de imagens com melhores resoluções. Após a expansão, foi possível verificar que as amostras exibiram estrutura dispersa e a presença de vazios com maior dimensão.

As análises de MEV das misturas, também, foram realizadas apenas para a condição antes do ensaio de expansão. As misturas argilosas mostraram-se bastante fissuradas e com a presença de vazios de diferentes dimensões. A presença de motmorilonita ficou bem evidente em todas as porcentagens. Foi observado, ainda, a presença de caulinita, haloisita e micas (ilita). O aspecto textural ficou bem semelhante ao das amostras compactadas somente com material da Formação Corumbataí.

Para as misturas arenosas, o MEV permitiu observar que as partículas de bentonita ficaram bem aderidas nas partículas de areia, promovendo um arranjo heterogêneo na mistura. Porém, em todas essas misturas, bem como nas misturas argilosas, a presença das fissuras, trincas e 
vazios de difentes dimensões ficou muito evidente. $\mathrm{O}$ aumento da porcentagem de bentonita proporcionou a redução dos vazios das amostras.

\subsubsection{Expansão por Transferência de Vapor}

As amostras argilosas indeformadas e as compactadas na umidade ótima da Formação Corumbataí, ensaiadas na condição seca ao ar, não revelaram expansão com técnica da transferência de vapor, apesar de terem apresentado ganho de umidade após os testes.

Diante disso, conclui-se que a ausência da pressão de expansão nessas condições pode estar relacionada com a forma de umedecimento lento pelo processo de transferência do vapor. $\mathrm{O}$ ganho de umidade nas amostras alcançou os poros de maior tamanho, mas não suficientemente para distribuir aos poros de menor tamanho, onde são reveladas as pressões de expansão. Assim, a expansão ficou impossibilitada nos microporos que compreendem os espaços vazios intrapartículas.

Dessa forma, realizaram-se testes com o material da Formação Corumbataí, compactado seco na forma de pó. Esses ensaios revelaram expansão por transferência de vapor (110 kPa), porém, esse valor ainda foi significativamente inferior à expansão por inundação.

Esse avanço na pesquisa permitiu analisar a expansão por transferência de vapor em diferentes misturas desse material com bentonita, e também, de misturas de bentonita com material não expansivo, no caso, material arenoso, de maneira a se avaliar a influência do tipo de argilomineral na expansão.

A máxima pressão de expansão obtida nas misturas com material argiloso foi justificada pela elevada capacidade de absorção de água, que está intimamente ligada, mais uma vez, com as condições iniciais de sucção imposta, o que permitiu tal variação de volume. Assim, ficou evidente a importância da porcentagem de bentonita nas pressões de expansão. No que se refere às condições iniciais, as amostras mais secas revelaram maior expansão. Isso confirmou as informações discorridas na literatura a respeito do comportamento expansivo de materiais argilosos.

\subsubsection{Expansão Inundada versus Transferência de Vapor}

Comparando-se as pressões de expansão obtidas pelas duas técnicas, concluiu-se que as misturas argilosas e arenosas com altos teores de bentonita (acima de 70\%) ensaiadas com a 
transferência de vapor mostraram resultados de expansão semelhantes ou maiores que os inundados.

Os resultados permitiram concluir que o ensaio de expansão com transferência de vapor não foi efetivo para avaliar o potencial expansivo de materiais argilosos sem a presença ou com baixos teores de argilominerais do grupo das esmectitas, no caso as misturas de $5 \%$ e $10 \%$ de bentonita. Em contrapartida, para materiais cujo potencial expansivo é elevado, essa técnica pode ser aplicada amplamente para medir a expansão. Visto que, o umedecimento por vapor pode se dar na prática em camadas subsuperficiais confinadas em que o nível d’água está mais profundo, ou simplesmente, pela infiltração de água da superfície nas camadas adjacentes ao material expansivo.

\subsection{Metodologias de Ensaio - Equipamento Desenvolvido na Pesquisa}

O equipamento desenvolvido nesta pesquisa mostrou desempenho satisfatório. Foi de fácil manuseio, simples montagem e apresentou bastante eficiência. A construção de cinco prensas iguais permitiu a aceleração do tempo da pesquisa, uma vez que os ensaios, conduzidos com a transferência de vapor, levaram em média dois meses e meio para cada amostra.

As sucções finais obtidas ao término de cada ensaio com a técnica da transferência de vapor foram correspondentes com o valor de sucção desejado de $5.000 \mathrm{kPa}$. Esse resultado confirma o perfeito funcionamento dos aparatos desenvolvidos na pesquisa para impor e controlar a sucção nos corpos de prova.

A prensa manual permitiu maior controle do carregamento dos ensaios a volume constante, com boa resposta dos sinais da célula de carga. Esses sinais mostraram-se compatíveis com o sistema de aquisição de dados, o qual permitiu o total controle da pressão de expansão das amostras. As células edométricas utilizadas tanto para inundação, como para a transferência de vapor, também apresentaram ótimo desempenho, sem vazamentos e sem interrupção do ensaio.

\subsection{Sugestões para Trabalhos Futuros}

Algumas sugestões são expostas para melhorar e aprofundar futuras pesquisas sobre a expansão de materiais argilosos, destacando-se: 
- Ensaiar o material da Formação Corumbataí compactado seco na forma de pó em diferentes densidades $\left(\rho_{\mathrm{d}}\right)$, mas com o mesmo teor de umidade para verificação da expansão;

- Ensaiar o material da Formação Corumbataí compactado seco na forma de pó com a mesma densidade $\left(\rho_{\mathrm{d}}\right)$, porém, em diferentes teores de umidade para verificação da expansão;

- Analisar de forma micromorfológica, através de lupa binocular e microscópio óptico sob lâminas delgadas antes e após os ensaios de expansão por transferência de vapor a fim de verificar com maior exatidão a macroporosidade e a microporosidade.

- Analisar outras proporções de bentonita entre os intervalos de $10 \%$ e $30 \%$ para verificar a partir de que porcentagem a expansão se iguala a do solo seco compactado sem bentonita.

- Ensaiar todas as amostras sob diferentes níveis de sucção e verificar as pressões máximas correspondentes em cada nível no mesmo ensaio.

- Ensaiar amostras com a mesma proporção de mistura com bentonita em diferentes densidades com a técnica da transferência de vapor. 


\section{REFERÊNCIAS BIBLIOGRÁFICAS}

_. NBR 6459: determinação do limite de liquidez, Rio de Janeiro, 1984.

. NBR 6508: grãos de solo que passam na peneira $4,8 \mathrm{~mm}$ - determinação da

. NBR 7180: determinação do limite de plasticidade, Rio de Janeiro, 1984.

_. NBR 7181: análise granulométrica, Rio de Janeiro, 1984.

ASSOCIAÇÃO BRASILEIRA DE NORMAS TÉCNICAS (ABNT).

American Association of State Highway and Transportation Officials - AASHTO. (2004) M145-91: Standard Specification for Classification of soils ans soil-aggregate mixtures for highway construction purposes. AASHTO, Washington.

Aitchinson, G. D.; Woodburn, J. A. (1969) Soil suction in foundation design. Proceedings, $7^{\text {th }}$ International Conference on Soil Mechanics and Foundation Engineering, Vol. 2. Pp. 1 - 8.

Alferes, R. (2011) Comportamento hidro-mecânico de solos compactados com diferente teor em água de compactação. Revista Ciêntifica, Academia da Força Aérea, pp.66 - 79, Lisboa.

Alonso, E. E.; Gens, A., Josa, A. (1992) A unified model for expansive soil behavior. In Proceedings of the 7th International Conference on Expansive Soils, Dallas, Tex., 3-5 August. Texas Tech Univerity Press, Lubbock, Tex. pp. 24-29.

Attom, M. F.; Barakat, S. A. (2000) Investigation of three methods for evaluating swelling pressure of soils: Environmental Engineering Geoscience. Vol. 6, No. 3, pp. 293-299.

American Society for Testing and Materials - ASTM (1991) Standard practice for maintaining constant relative humidity by means of aqueous solutions (E-104-85). Annual Book of ASTM Standards, Philadelphia, P. A.

Basma, A. A.; Al-Homoud, A.; Husein, A. (1995) Laboratory assessment of swelling pressure of expansive soils. Applied Clay Science, 9, p. 355 - 368.

Barden, L.; Mededor, A. O.; Sides, G. R. (1969) Volume change characteristics of unsaturated clays. Journal of Soil Mechanics and Found. Div. ASCE, 95, pp. 33 - 51. 
Baver, L. D.; Gardner, W. H. (1972) Soil physics. 4ª Edição, London, Wiley \& Sons. Inc., 1972.

Bernier, F.; Volckaert, G.; Alonso, E. E.; Villat, M. V. (1997) Suction-controlled experiments on Boom Clay. Engineering Geology, 47 (4): pp. 325 - 338.

Blatz, j.; Graham, J. (2000) A system for controlled suction in triaxial tests. Géotechnique, 50 (4): pp. $465-469$.

Blatz, J. A.; Cui, Y. J.; Oldecop, L. (2008) Vapour equilibrium and osmotic technique for suction control. Geotech Geol Eng, 26, p. 661 - 673.

Bolt, G. H. and Miller, R. D. (1958) Calculation of total component potencials of water in soil. Trns. Amer. Geophys. Un., v. 39, nº 5, pp. 917-928.

Brekke, T. L. (1965) On the Measurement of the Relative Potencial Swellability of Hydrothermal Montmorilonite Clay from Joints and Faults in Pre-Cambrian and Paleozoic Rocks in Norway. Internacional Journal of Rock Mechanincs and Mining Science. Vol. 2, p. 155-165.

Brooks, R. H.; Corey, A. T. (1964) Hydraulic properties of porous media. Colorado State Univ. Hydrol, no 3 , p.27.

Coleman, J. D. (1959) An investigation of the pressure method for measuring the suction properties of soil. Road Res. Laboratory Note $\mathrm{n}^{\circ} 3464$, Crowthorne, UK.

Camapum de Carvalho, J.; Leroueil, S. (2004) Curva característica de sucção transformada. Revista Solos e Rochas, São Paulo, 27, (3), p. 231 - 242.

Campos, J. O. (1989) A desagregabilidade dos siltitos da Formação Corumbataí consequências práticas, fenomenologia provável e experimentação pertinente. Tese (Livre Docência) Rio Claro, UNESP, p. 120.

Cardoso, F. B. F. (1995) Análise química, mineralógica e micromorfológica de solos tropicais colapsíveis e o da dinâmica do colapso. Dissertação (Mestrado), Universidade de Brasília, 140p. 
Cardoso, R.; Reis, A.; Barata, R. (2012) Estudo micromecânico do comportamento volumétrico de solos argilosos compactados. XIII Congresso Nacional de Geotecnia, Lisboa, Portugal.

Casagrande, A. (1948) Classification and Identification os Soils. Transactions ASCE, Vol 113, 901/991, New York.

Chandler, r. 1.; Crilly, m. s.; Montgomery-smith, g. (1992) A low-cost method of assessing clay desiccation for low-rise buildings. Proc. Of the Institution of Civil Engineering, 82-89.

Chen, F. H. (1965) The use of piers to prevent the uplifting of lightly loaded structures fonded on expansive soil. Proc. Eng. Effects of Moistures Changes in Soils, Int. Res. Eng. Conf. Expansive Clays Soils. Supplementing the Symposium in Print, Texas, A \& M Press., p. 152171.

Chen, F. H. (1975) Foundation on expansive soils. Developments in Geotechnical Engineering, Amsterdam, Elsevier, 12:280.

Chen, F. H. (1988) Foundations on expansive soil. Elsevier Science Publishing Company Inc., New York.

Çimer, O.; Keskin, S. N.; Yildirum, H.; Prediction of swelling potential and pressure in compacted clay. Arab J Sci Eng, 37, p. 1535 - 1546.

Coleman, J. D. (1962) Stree-strain relations for partly saturated soils. Geotéchnique. Vol. 12, p. $348-350$.

Cristelo, N. (2001) Estabilização de solos residuais graníticos através da adição de cal. Tese (Doutorado) Universidade do Minho, Portugal.

Cuisiner, O.; Masrouri, F. (2003) Testing the hydromechanical behavior of a compacted swelling soil. Geotechnical Testing Journal, Vol. 25, $\mathrm{n}^{\mathrm{o}} 6$.

Cui, Y. J.; Delage, P. (1996) Yielding and plastic behavior of an unsaturated compacted silt. Géotechnique 46(2), p. 292-311.

Cui, S.; Zhang, H.; Zhang, M. (2012) Swelling characteristics of compacted GMZ bentonitesand mixtures as a buffer/backfill material in China. Engineering Geology 141 - 142, pp. 65 -73 . 
Delage, P.; Suraj de Silva, G. P. R.; Vicol, T. (1992) Suction controlled testing of non saturated soils with an osmotic consolidometer. In: Prodeedings $7^{\text {th }}$ International Conference on Expansive Soils. Dallas, p. 206-211.

Delage, P.; Howat, M. D.; Cui, Y. J. (1998) The relationship between suction and swelling properties in a heavily compacted unsaturated clay. Engineering Geology, 50, p. 31 - 48.

Delgado, A. (1986) Influencia de la trayectoria de las tensiones en el comportamiento de las arcillas expansivas y de los suelos colapsables en el laboratorio y en el terreno. Sevillia, Universidad de Sevillia, 564p. (Tese de Doutorado).

Dueck, A. (2004) Hydro-mechanical properties of a water unsaturated sodium bentonite. Laboratory study and theoretical interpretation. Ph.D thesis, Lund University, Sweden.

EMBRAPA - Empresa Brasileira de Pesquisa Agropecuária (2007). Boletim Técnico: Determinação da curva de retenção de água no solo em laboratório. Piauí.

Erzin, Y.; Erol, O. (2004) Correlations for quick prediction of swell pressures. Electron. J. Geotech. Eng. 9, paper 0476.

Escario, V. (1967) Measurement of the swelling characteristics of a soil fed with water under tension. Int. Cooperative Res. On The Predictions of Moisture Contents under Road Paviments. O.C.D.E.

Escario, V. (1989). Formulaciones para la definición de la resisténcia al esfuerzo cortante de los suelos parcialmente saturados. Bol. Soc. Española de Mecánica del Suelo., 92, p.3-12.

Escario, V.; Saez, J. (1973). Measured of the properties of swelling and collapsing soils under controlled suction. In: Proc.3rd Int.Conf . Expansive Soils (Haifa)., p.195-200.

Esteban, F.; Saez, J. (1988). A device to measure the swelling characteristics of rock samples whit control of the suction up to very high values. ISRM, Symposium on rock mechanics and power plants, (Madrid), Vol. 2.

Esteban, F. (1990) Characterización experimental de la expansividad de una roca evaporítica. Ph.D. thesis, Universidad de Cantabria, Santader, Spain.

Everett, K. R. (1972) Soils of the Meserve Glacier área. Wright Valley, Southern Victoria Land, Antartica, Soil Sci., 112, pp. 425 - 438. 
Fagundes, J. R. T. (2010) Estudo integrado das características geológico-geotécnicas com vista à avaliação de recarga de aquífero: região de São Carlos-SP. Tese (Doutorado). Vol. I. 397 p. Universidade de São Paulo - Escola de Engenharia de São Carlos, São Carlos.

Ferreira, S. R. M (1988) Solos especiais - Colapsíveis, Dispersivos e Expansivo, Relatório Anual do CNPq.

Ferreira, S. R. M. \& Ferreira, M. G. V. X. (2009) Mudanças de volume devido à variação do teor de água em um vertissolo no semiárido de Pernambuco. Revista Brasileira de Ciência do Solo, n. 33, p. $779-791$.

Ferreira, S. R. M. (1995) Colapso e expansão de solos naturais não saturados devidos à inundação. Rio de Janeiro, Universidade Federal do Rio de Janeiro, 379p. (Tese de Doutorado).

Fonseca, E. C. (1991) Ensaio de cisalhamento direto com sucção controlada em solos não saturados. Rio de Janeiro, PUC, 173 p. (Dissertação de Mestrado).

Frazão E. B.; Goulart, E. P. (1976) Aspectos da expansibilidade de argilo-minerais : Algumas Implicações em Obras Civis. In: $1^{\circ}$ Congresso Brasileiro de Geologia de Engenharia, ABGE, São Paulo, Tema 11, 2: 351-365.

Fredlund, D. G,; Hasan, J. U. \& Filson, H. (1980) The prediction of total heave. Proc. Of the Fourth Int. Conf. on Expansive Soils, Denver-Colorado, Vol. 1, pp. 1 - 17.

Fredlund, D. G.; Rahardjo, H. (1993) Soil mechanics for unsaturated soils. New York, John Wiley \& Sons, Inc.1993. p.1-6.

Fredlund, D. G.; Morgenstern, N. R. (1996) The relationship of the unsaturated soil shear strengh to the soil-water characterist curve. Canadian Geotechnical Journal. Canadá, p. 440 448.

Fredlung, D. G.; Morgenstern, N. R. (1976) Constitutive realtions for volume change in unsaturated soils. Can. Geot. Journal, Vol. 13, nº 3, pp. $261-276$.

Fredlund, D. G.; Morgenstern, N. R. (1977) Stress state variables for unsaturated soils. Jounal of Geot. Div. ASCE., Vol. 103 GT5, p. 447-466. 
Fredlund, D. G.; Xing, A. (1994) Equations for the soil-water characteristic curve. Canadian Geotechnical Journal, Vol. 31, nº 3, pp. $521-532$.

Fredlund, D. G; Xiang, A. e Huang, S. (1994) Predicting the permeability functions for unsaturated soil using the soil-water characteristic curve. Canadian Geotechnical Journal. v. 31, n 34, p. 533-546.

Futai, MM. (1997) Análise de ensaios edométricos com sucção controlada em solos colapsíveis. Tese de doutorado,COPPE/UFRJ.

Georgetti, G. B.; Rodrigues, R. A.; Dourado, K. A.; Vilar, O. M. (2007) Avaliação do desempenho de uma câmara de pressão alternativa para obtenção da curva de retenção de água. In: VI Simpósio Brasileiro de Solos Não Saturados p. 313 - 320, Salvador - Bahia.

Georgetti. G. B. (2010) Resistência de um solo não saturado a partir de ensaios com teor de umidade constante $(C W)$. (Dissertação de Mestrado) p. 108. Universidade de São Paulo Escola de Engenharia de São Carlos, São Carlos.

Guerra, D. L.; Santos, M. R. M. C. and AIROLDI, C. Mercury adsorption on natural and organofunctionalized smectites - thermodynamics of cation removal. Journal of Brazilian Chemical Society, v.20, n.4, p.594-603, 2009.

Gray, M. N. S.; Cheung, C. H.; Dixon, D. A. (1985) Swelling pressure of compacted bentonite/sand mixtures. AECL TR-350, pp. 776 - 785, Canadá.

Grim, R. E. (1953) Clay Mineralogy. McGraw-Hill Publ. Company Ltda, New York, 384p.

Hardned, H. S.; Owen, B. B. (1958) The physical chemistry of electrolyte of electrolyte solutions. $3^{\text {rd }}$ Edn. Reinhold: New York.

Hillel, D. (1971) Soil water - Physical principles and processes. New York, Academic Press, 1971. Cap. $1-5$.

Hillel, D. (1980) Fundamental of soil physics. New York, Academic Press, p. 413.

Hilf, J. W. (1956). An investigation of pore-water pressure in compacted cohesive soils. Denver, 1956. 109 p. (Doutorado - Faculty of the Graduate Scholl of the University of Colorado). 
Holtz, W. G. \& Gibbs, H. J. (1956) Engineering properties of expansive clays. Transact. ASCE, 121 p. $641-677$.

Holtz, W. G. (1969) Expansive Clays-properties of expansive clays. Transact. ASCE, 121, p.641-677.

I.N.S.A Instituto Nacional do Semi-árido (2013) Manejo de irrigação utilizando o tensiômetro: Cartilha 2013.

I.S.R.M. Inter. Soc. For Rock Mech. (1972) Suggested methods for determining water content, porosity, density, absortion and related properties and swelling and slake-durability index properties. Document n 2, final Draft, Lisbon, Portugal, p. 142 - 156.

I.S.R.M. Inter. Soc. For Rock Mech. (1989) Comission on swelling rock and working group on swelling rock of the commission on testing methods. Suggested methods for laboratory testing of argillaceous swelling rocks. Int. J. Rock Mech. Min. Sci. \& Geomech. Abstr. Vol. 26. N 5, p. $415-426$.

IAEG (1979) Classification of rocks and soils for engineering geology mapping. Part 1: rock and soil materials. Bulletin of the International Association of Engineering Geology, Krefeld, 19: $364-371$.

International Union of Pure and Applied Chemistry - IUPAC (1985) Reporting Physisorption Data for Gas/Solid Systems with special reference to the determination of surface area and porosity. Pure \& Appl. Chem. V. 57, pp. 603 - 619.

Johnson, L. D. (1978) Predicting potencial heave and heave with time in swelling foundation soils. Technical Report S-78-7, U.S. Army Engineer Waterways Experiment Station, CE, Viksburg, Miss.

Jotinsanka, A.; Coop, M.; Ridley, A. (2007) The development of a suction control sustem for a triaxial apparatus. Geotechnical Testing Journal, 30 (1): 69 - 75.

Jucá, J. F. T. e Lins, A. H. P. (1992) Estudo do comportamento dos solos não saturados na Universidade Federal de Pernambuco. Seminário sobre solos não saturados. Brasília-DF. Vol. 1, pp. 71-108. 
Justo, J.L.; Delgado, A.; Ruiz, J. (1984) The influence of stress-path in the collapse swelling of soils at the laboratory. Proceedings, $5^{\text {th }}$ International Conference on Expansive Soils, Adelaide, pp. 67-71.

Jones, D. E.; Jones, K. (1987). Treating Expansive Soils, ASCE, Civil Engineering, Vol. 57, No. 8 .

Kennings, J. E. B.; Knight, K. (1957) The additional settlement of foundation due to a collapse of structure of sandy sub soils on wetting. In: Int. Conf. On Soil Mech. And Found. Eng., 4, London, Vol.1, pp. 316 - 219.

Kassif, G.; Ben Shalom, A. (1971) Experimental relationship between swell pressure and suction. Géotechnique 21 (3), p. 245-255.

Kayabali, K.; Demir, S. (2011) Measurement of swelling pressure: direct method versus indirect methods. Can. Geotch. Journal. 48: pp. 354 - 364.

Komine, H. (2004) Simplified evaluation for swelling characteristics of bentonites. Engineering Geology. 71, p. 265 - 279.

Komine, H.; Ogata, N. (2004) Predicting swelling characteristics of bentonites. Journal of Geotechnical and Geoenvironmental Engineering. ASCE, Vol: 130, No.8., pp 818-829.

Lambe, T. W. (1960) A mechanistic picture of shear strength in clay. Research Conf. On Shear Sternght Coehesive Soils, Boulder, Colorado, p. 555-580.

Lambe, T. W.; Whitman, R. V. (1969) Soil mechanics. New York, Jhon Wiley \& Sons, Inc. $553 \mathrm{p}$.

Lan, T. N. (1977) Um nouvel essai d'identification dês sols: I'essai au bleu de méthylène. Bull. Liaison Lab.Ponts Chaussees 88, p.136-137.

Lang, A. R. G. (1967) Osmotic coeffcient and water potentials of sodium chloride solutions from 0 to $40^{\circ} \mathrm{C}$. Australian Journal of Chemistry, 20, 0. 2017-2023.

Lautrin, D. (1989) Utilisation pratique des parameters derives de l'essai au bleu de máthylène dans projects de génie civil. Bull. Lab. P. et. Ch, fevr. - mars. p. 53-65.

Lee, J. O.; Lim, J. G.; Kang, I. M.; Kwon, S. (2012) Swelling pressure of compacted Cabentonite. Engineering Geology, p. 129 - 130. 
Leite, J. C. (2000) Estudos laboratorias de percolação em colunas de misturas de solso lateríticos compactadas: Equipamentos e Ensaios. Tese (Doutorado). Escola de Engenharia de São Carlos, Universidade de São Paulo, São Carlos.

Le Roux, A (1976) Classification des différentes textures de roches argileuses et marneuses em relation avec leur comportement. Bull. Liaison Labo. P. et Ch, spécial, décembre. p. 3948.

Libardi, P. L. (1995) Dinâmica da água no solo. Edição do Autor, ESALQ, Dept. de Física e Meteorologia, Piracicaba, 497 p.

Likos, W. J.; Lu, N. (2007) Automated measurement of total suction characteristics in highsuction range. Transportation Research Record 1755, nº 01-0303, pp. 119- 128.

Lloret, A.; Vilar, M.; Sanchez, M.; Gens, A.; Pintado, X.; Alonso, E. E. (2003) Mechanical behaviour of heavily compacted bentonite under high suction changes. Géotechnique, Vol. 53 , p. $27-40$.

Loch. F. C. (2013) Barreiras de solos estabilizados com cal e cimento para proteção ambiental. (Dissertação de Mestrado) p. 241. Universidade de São Paulo - Escola de Engenharia de São Carlos, São Carlos.

Loiseau, C. (2001) Transfer d'eau et couplages hydromécaniques dans les barriers ouvragées. Ph. D. thesis, Écola nationale des ponts et chaussées, Paris, France.

Luxmoore, R. J. (1980) Micro, meso and macroporosity of soil. Soil. Sci. Soc. Am. Journal, Vol. 45, pp. $671-672$.

Machado, S. L.; Vilar, O.M. (1995). Estudo da compressão confinada e do colapso de um solo arenoso compactado em edômetro de sucção controlada. Escola de Engenharia de São Carlos, Universidade de São Paulo. (Dissertação de Mestrado).

Mackenzie, R. C. (1957) The differential termal investigation of clays. Mineralogical society (Clay Mineral Group), London.

Marcial, D.; Delage, P.; Cui, Y. J. (2002) On the high stress compression of bentonites. Canadian Geotechnical Journal, 39 (4), pp. 812 - 820. 
Marinho, F. A. M. (1994). Medição de sucção com o método do papel de filtro. Anais... X COBRAMSEF, v. 2, p. 515 - 522.

Marinho, F. A. M.; Chandler, R.J. and Crilly, M. (1995) Stiffness measurements on an unsaturated high plasticity clay using bender elements. First International Conference on Unsaturated Soils - Paris.

Marinho, F. A. M., Pereira, J. H. F. (1998) Mini-curso: Solos não saturados. XI Congresso brasileiro de mecânica dos solos e engenharia geotécnica - Brasília - Brasil.

Marinho, F. A. M. (2001) Considerações sobre o fluxo unidimensional em meio não saturado. In: Simpósio Brasileiro de Solos Não Saturados, 2. Porto Alegre.

Marques, L. G. (2008) Liofilização de frutas tropicais. (Doutorado em Engenharia Química) Tese. 255p. Universidade Federal de São Carlos. São Carlos, São Paulo.

Marshall, T. J. (1958) A relation between permeabilityand size distribution of pores. Journal of Soil Science, Oxford, 9 (1): $1-8$.

Mata, V. L. G. (1998) Caracterização de meios porosos: Porosimetria, Modelização 3D e Tomografia seriada - Aplicação e Suporte. Tese de doutorado, 304p. Universidade do Porto, Portugal.

Mc Keen, R. G. (1992) A model for predicting expansive soil behavior. $7^{\text {th }}$ International Conference on Expansive Soil. Dallas-Texas, Vol. 1, pp. 1 - 11.

Mc Keen, R. G.; Hamberg, D. J. (1981) Characterization of expansive soils. Transportation Reaserch Record. pp. 73 - 78, Washington, United States.

Menezes, M. B. M.; Pejon, O. J. (2010) Análise da influência do teor de umidade na absorção d'água e sucção dos solos em estudos de erodibilidade. Geociências, UNESP, V. $29, \mathrm{n}^{\mathrm{o}} 2$, pp. $211-218$.

Miguel, M. G.; Teixeira, R. S.; Padilha, A. C. C. (2006) Curva característica de sucção do solo laterítico da região de Londrina - PR. Revista de Ciência e tecnologia, v. 12, n. 24, pp. $63-74$.

Mitchell, J. K. (1993) Fundamentals of soil behavior. $2^{\text {nd }}$ ed., Ed. John Wiley \& Sons, Inc. U.S.A, p. 473. 
Mitchell, J. K. (1976) Fundamentals of Soil Behavior. New York, John Willwy \& Sons, USA. 1976. 422p.

Montes-H, G.; Duplay, J.; Martinez, L.; Mendoza, C. (2003) Swelling-shrinkage kinetics of MX80 bentonite. Applied Clay Science, 22: 279 - 293.

Moore, D. M.; Reynolds Jr., R. C. (1989) X-Ray Diffraction and the Identification and Analysis of Clay Minerals. Oxford University Press, 332pp.

Muggler, C.C.; Sobrinho, F.A.P.; Machado, V.A. (2005) Educação em solos: princípios e pressupostos metodológicos. In: Congresso Brasileiro de Ciência do Solo, 30, Recife. Anais. Recife, Sociedade Brasileira de Ciências do Solo.

Muro, M. D. (2000) Carta de zoneamento para seleção de pares frente à instalação de aterros sanitários no municipio de São Carlos - SP Escala 1:50.000. Dissertação (Mestrado). 2 V. Escola de Engenharia de São Carlos, Universidade de São Paulo, São Carlos.

Musso, M. A. (2004) Evaluación del comportamiento al transporte de contaminantes de barreras impermeable de arcilla compactada (CCL) de la Fm. Corumbataí y su comparación con un geocompuesto bentonítico $(G C L)$ brasilero. (Projeto de Doutorado) Escola de Engenharia de São Carlos - Universidade de São Paulo.

Murthy, V. N. S. (2003) Geotechnical Engineering: Principles and Practices of Soil Mechanics.

Oliveira, T.S. (1992) Efeitos dos ciclos de umedecimento e secagem sobre propriedades físicas e químicas de quatro Latossolos brasileiros. Dissertação (Mestrado) Universidade Federal de Viçosa, Viçosa. 102p.

Olphen, H. V. (1963) An introduction to clay colloid chemistry. Willey Interscience, New York, $301 \mathrm{p}$.

Pacey, J. G. Jr. (1956) The structure of compacted soils. M. S. Thesis, M.I.T.

Pearring, J. R. (1963). A study of basic mineralogical, physico-chemical and engineering index properties of laterite soils. PhD Dissertation, Texas A\&M University, College Station. 
Pejon, O. J. (2000) Estudo dos fenômenos de expansão de rochas sedimentares de granulometria fina. Identificação, caracterização e mapeamento. Livre docência. Escola de Engenharia de São Carlos - Universidade de São Paulo.

Pereira, E. M.; Pejon, O. J. (1999) Estudo do potencial expansivo dos sedimentos argiloso da Formação Guatiroba na Região de Alto Iguaçú - PR. 9 Congresso Brasileiro de Geologia de Engenharia. ABGE, publicação em CD - 16p, São Pedro - SP.

Pereira, E. M. (2004) Estudo do comportamento à expansão de materiais sedimentares da Formação Guatiroba em ensaios com sucção controlada. Tese (Doutorado). Escola de Engenharia de São Carlos - Universidade de São Paulo.

Prakash, K. \& Sridharan, A. (2004) Free swell ratio and clay mineralogy of fine-grained soils. Geotechnical Testing Journal, Vol. 27, N 2.

Perinotto, J. A.; Etchubehere, M. L. C.; Simões, L. S. A.; Zanardo, A. (2008) Diques clásticos na Formação Corumbataí (P) no Nordeste da Bacia do Paraná, SP: Análise sistemática e significações estratigráficas, sedimentológicas e tectônicas. Geociências, UNESP, v. 27, nº 4, pp. $469-491$.

Perinotto, J. A.; Lino, I. C. (2014) Geologia, recursos minerais e passivos ambientais. s.d. Disponível em: <http://ceapla.rc.unesp.br/atlas/atlas.html> Acesso em: 26 jun. 2014.

Petry, T. M.; Sheen, J.-S.; Armstrong, J. C. (1992) Effects of pretest stress environments on swell. In Proceedings of the 7th International Conference on Expansive Soils, Dallas, Tex., 35 August. American Society of Civil Engineers, New York. pp. 39-44.

Pintado, X.; Lloret, A.; Romero, E. (2009) Assessment of the use of the vapour equilibrium techniquein controlled-suction tests. Canadian Geotecnical Journal, 46, p. 411 - 423.

Pinto, C. S. (2000) Curso básico de Mecânica dos Solos. São Paulo: Oficina de Textos.

Popescu, M. E. (1986) A comparison between the behavior of swelling and of collapsing soil. Engineering Geology, Vol. 23, nº 2, pp. $145-163$.

Presa. E. P. (1984) Deformabilidad de las arcillas expansivas bajo succión controlada. Tesis (Doctoral) E.T.S. de Ing. De Caminos, Canales Y Puertos, Universidad Politécnica de Madrid, Espana. 
Presa, E. P. (1991) Efeitos das trajetórias de tensão e sucção nas variações volumétricas de solos não saturados. In: SEFE p. $304-314$.

Raij, B. V. (1969) A capacidade de troca de cátions das frações orgânica e mineral em solos. Bragantia 28: 85-112.

Rao, R. R.; Rahardjo, H.; Fredjund, D. G. (1988) Close from heave solutions for expansive soils. Jounal Geotech. Eng. ASCE, Vol. 114, nº 5, pp. 573 - 588.

Rao, A. S.; Phanikumar, B. R.; Sharma, R. S. (2004) Prediction os swelling characteristics of remoulded and compacted expansive soils using free swell index. Quartely Journal of Engineering Geology and Hydrogeology, 37, pp. 217 - 226.

Rao, K. M.; Babu, G. G.; Rani, C. S. (2006) Influence of coarse friction on swelling characteristics. The electronic Journal of Geotechnical Engineering.

Reichardt, K. (1985) Processos de transferência no sistema solo - planta-atmosfera. Fund. Cargill, Campinas, 466p.

Richards, L. A. (1965) Physical conditions of water in soil. In: C. A. BLACK, D. D. EVANS, J. L. WHITE, L. E. ENSMINGE and F. E. CLARK, ed. Methods of soil analysis - Physical and mineralogical properties, including statistics of measurements and sampling. Madison, ASASSSA. p.128-152.

Ridley, A.M.; Burland, J.B. (1993). A New Instrument for Measuring Soil Moisture Suction. Geotechnique, Vol. :, pp.

Rohm, S. A. (1993) Solos não saturados. (Monografia da especialização em geotecnia) 135p., Universidade de São Paulo, São Paulo.

Rohm, S.A. (2004) Solos Não Saturados. Departamento de Geotecnia, EESC, USP, São Carlos, Monografia Geotécnica, nº. 4, 135 p.

Romero, E. (1999) Characterisation and thermo-hydro -mechanical behavior of an unsaturated Boom clay: an Experimental Study. Tese (Doutorado), Universidade Politécnica da Catalunya, Barcelona, Espanha. 
Romero, E.; Gens, A.; Lloret, A. (1999) Water permeability, water retention curve and microestruture of unsaturated compacted Boom clay. Engineering Geology, 54, pp.117-127.

Saiyouri, N.; Hicher, P. Y.; Tessier, D. (2000) Microestructural approach and transfer water modeling in highly compacted unsaturated swelling clays. Mechanics of Cohesive Frictional Mater 5, pp. $41-60$.

Santos, P. S. (1992) Ciência e tecnologia de argilas. Ed. 2. Revisada e Ampliada, São Paulo. Edt. Edgard Blucher Ltda. Vol 3.

Santos, P.S.; Santos, H.S. (1989-1992) Ciência e tecnologia de argilas. 2. ed. rev. e ampl. São Paulo: Edgar. Blucher, 3v., 1089p.

Seed, H. B., Chan, C. (1959) Structure and strength characteristics of compacted clays. Journal Soil Mechanics Foundation Div., ASCE, 85 (SM1), 87-128.

Seed, H. B.; Woodward, R. J. e Lundgren, R. (1962) Prediction of swelling potencial for compacted clays. Proc ASCE, Journal Mechanics and Foundations Division, Vol. 88, SM3, pp. $53-87$.

Shuai, F. (1996) Simulation of swelling pressure measurements on expansive soils. Ph.D. Thesis, University of Saskatchewan, Saskatoon, Sask.

Shreiner, H. D. (1987) State of the art reviem on expansivo soils. Imperial College, London.

Silva, A. M. (2005) Banco de dados de curvas de retenção de água de solos brasileiros. (Dissertação de Mestrado) Universidade de São Paulo, Escola de Engenharia de São Carlos Departamento de Geotecnia, São Carlos, São Paulo.

Skempton, A. W. (1953). The colloidal activity of clays. Proc. 3rd Int. Conf. Soil. Mech. Found. Eng., Switzerland. Vol.1, p. 57 - 61.

Silva, M. V. C. (2011) Caracterização reológica da argila bentonítica derivada do intemperismo de basaltos - Formação Mosquito, Bacia do Parnaíba, sul do Maranhão. Relatório Técnico - Científico, Universidade Federal do Pará, 2011.

Snethen, D. R.; Townsend, F. C.; Johnson, L. D.; Patrick, D. M.; Vedros, S. P. J. (1975) Review of engineering experiences with expansive soils in highway subgrades. US Army Engineer Water Ways Experiment Station, FHWA, USA. 
Soto, M. A. A. (2004) Comparação entre métodos de imposição e controle de sucção em ensaios com solos não saturados. Tese (Doutorado) Escola de Engenharia de São Carlos Universidade de São Paulo.

Souza, R. F. C. (2009) Migração de poluentes inorgânicos em liners compostos. Dissertação (Mestrado) Universidade de São Paulo, Escola de Engenharia de São Carlos - Departamento de Geotecnia, São Carlos, São Paulo.

Sridharan, A.; Sreepada, R. A.; Sivapullaiah, P. V. (1986) Swelling pressure of clays. Geotechnical Testing Journal ASTM 9 (1), pp. $24-33$.

Tang, A. M.; Cui, Y. J. (2005) Controlling suction by the vapour equilibrium technique at different temperatures and its application in determining the water retention properties of MX80 clay. Canadian Geotechnical Journal, 42, p. 287 - 296.

Tang, C. S.; Tang, A. M.; Cui, Y. J.; Delage, P.; Schroeder, E. De Laure. (2011) Investigating teh swelling pressure of compacted crushed-Collovo-Oxfordian claystone. Physics and Chemistry of the Earth, 36, p. $1857-1866$.

Taylor, R. K.; Smith, J. (1986) The engineering geology of clay mineral: swelling, shrinking and mudrock breakdown. Clay Minerals, 21, p. 235 - 260.

Terzaghi, K. (1936) The shearing resistance of saturated and the angle between the planes of shear. In: International Conference on Soil Mechanics and Foundation Engineering, $1^{\circ}$, Proceedins..., Cambridge, International Society for Soil Mechanics and Foundation Engineering, 1:54-56.

Tessier, D.; Beaumont, A.; Pedró, G. (1990) Influence of clay mineralogy and rewetting rate on the clay microstructure. In: Soil micromorphology: a basic and applied science. International Work Meeting of Soil Micromorphology, 8. San Antonio, 1988. Proceedings. Amsterdam, Elsevier Science. p.191 - 198.

Thom, R.; Sivakumar, R.; Sivakumar, V.; Murray, V. e Mackinnon, P. (2007) Pore size distribution of unsaturated compacted kaolin: the initial states following saturation. Géotechnique, 57(5), pp. 469-479.

Thomas, P. J.; Baker, J. C.; Zelazny, L. W. (2000) An expansive soil index for predicting shrink-swell potential. Soil Science Society of America Journal, 64(1): 268-274. 
Tien, Y.; Wu, P. L.; Chuang, W. S.; Wu, L. H. (2004) Micromechanical model for compaction characteristics of bentonite-sand mixtures. Applied Clay Science, Vol. 26, pp. $489-498$.

Van der Merwe, D. H. (1964) The prediction of heave from the plasticity index and percentage Clay fraction of soils. Trans. S. Afr. Inst. Of Civ. Engrs. Vol. 6, n. 6.

Van Genuchten, M.T. (1980). A closed-form equation for predicting the hydraulic conductivity of unsaturated soils. Soil Sci. Soc.Am.J., vol. 44, n 5, pp. 892 - 898.

Vilar, O. M. \& Gandour, R. (1992) A expansibilidade de sedimentos da Formação Corumbataí quando compactados. Revista Geociências, 11 (2) p.163-179, São Paulo.

Vilar, O. M. (1997) Introdução à mecânica de solos não saturados. Notas de aula.

Vilar, O. M. (2000) Introdução à mecânica de solos não saturados. Notas de aula.

Villar, M. V. (1999) Investigation of the behaviour of the bentonite by means of suctioncontrolled oedometer test. Engineering Geology, 54 (1-2): pp. 67 - 73.

Villar, L. F. (2002) Estudo do adesamento e ressecamento de resíduos de mineração e processamento de bauxita. Tese de doutorado. PUC/RJ. Departamento de Engenharia Civil.

Washburn, E. W. (1921) The dynamics of capillary flow. Phys. Rev., 17, 273-283.

Wayllace, A. (2008) Volume change and swelling pressure of expansive clay in the crystalline swelling regime. Tese de Doutorado, 135p. University of Missouri, Missouri.

Webb, P. A.; Orr, C. (1997) Analytical methods in fine particle technology. Micromeritics Instrument Corporation, 300p.

Williams, A. A. B.; Donaldson, G. W. (1980) Building on expansive soils in South Africa. 1973 - 1980. Proceedings 4th International Conference on Expansive Soils, Vol. II, Denver, Colorado, p. $834-844$.

Williams, J.; Shaykewich, C. F. (1969) An evaluation od pdy ethylene glycol (PEG) 6000 and PEG 20000 in the osmotic control of soil water matric potential. Canadian Journal os Soil Science, 102 (6), p. 394 - 398. 